Intensifying inequality in the 'sustainable city':

\title{
A political ecology of 'smart growth' in an era of neoliberal urban governance in the City of Ottawa, Canada
}

\section{By Abra Adamo}

A thesis submitted to the Faculty of Graduate and Postdoctoral Affairs in partial fulfillment of the requirements for the degree of

\author{
Doctor of Philosophy \\ in \\ Geography \\ Carleton University \\ Ottawa, Ontario
}

(C) 2012

Abra Adamo 
Library and Archives

Canada

Published Heritage

Branch

395 Wellington Street

Ottawa ON K1A ON4

Canada
Bibliothèque et

Archives Canada

Direction du

Patrimoine de l'édition

395 , rue Wellington

Ottawa ON K1A ON4

Canada
Your file Votre référence

ISBN: 978-0-494-93669-6

Our file Notre référence

ISBN: 978-0-494-93669-6
NOTICE:

The author has granted a nonexclusive license allowing Library and Archives Canada to reproduce, publish, archive, preserve, conserve, communicate to the public by telecommunication or on the Internet, loan, distrbute and sell theses worldwide, for commercial or noncommercial purposes, in microform, paper, electronic and/or any other formats.

The author retains copyright ownership and moral rights in this thesis. Neither the thesis nor substantial extracts from it may be printed or otherwise reproduced without the author's permission.
AVIS:

L'auteur a accordé une licence non exclusive permettant à la Bibliothèque et Archives Canada de reproduire, publier, archiver, sauvegarder, conserver, transmettre au public par télécommunication ou par l'Internet, prêter, distribuer et vendre des thèses partout dans le monde, à des fins commerciales ou autres, sur support microforme, papier, électronique et/ou autres formats.

L'auteur conserve la propriété du droit d'auteur et des droits moraux qui protege cette thèse. $\mathrm{Ni}$ la thèse ni des extraits substantiels de celle-ci ne doivent être imprimés ou autrement reproduits sans son autorisation.
In compliance with the Canadian Privacy Act some supporting forms may have been removed from this thesis.

While these forms may be included in the document page count, their removal does not represent any loss of content from the thesis.
Conformément à la loi canadienne sur la protection de la vie privée, quelques formulaires secondaires ont été enlevés de cette thèse.

Bien que ces formulaires aient inclus dans la pagination, il n'y aura aucun contenu manquant. 


\begin{abstract}
In recent years, municipal governance in Canada has undergone dramatic transformation. In an era of intense political economic restructuring and reform at different spatial scales, the rolling back of national state regulation, the retrenchment of public finance, the devolution of senior government responsibilities to local municipalities and the triumph of a 'growth first' neoliberal ideology (Peck and Tickell 2002) have produced a discernable shift towards more entrepreneurial and competitive styles of urban governance through which municipal governments, in concert with real estate developers, business leaders and other actors, have sought to mobilize city space to attract new capital investment and labour in a bid to strengthen (and sustain) urban economic competitiveness and secure long-term growth.
\end{abstract}

The neoliberalization of urban governance and policy regimes, however, comes at a time when municipalities are also facing growing public demands to protect and preserve local and regional environments, and the global biosphere, from the kind of predatory 'growth first' development agenda driving the current era of municipal policymaking. Though the rise of neoliberal urban governance regimes appears to be at odds with contemporary ideas of urban environmental 'sustainability', this thesis draws on, and seeks to contribute to, a growing body of scholarship in urban political ecology that documents the ways in which ideas of 'environment' and 'sustainability' and are becoming actively (though selectively) incorporated into the everyday politics, policies and development practices of contemporary neoliberal urbanization through a discourse of ecological modernization.

Using the City of Ottawa, Canada as a case study, this thesis explores recent smart growth-inspired policy reform experimentation premised on curbing low density suburban expansion - or 'sprawl' - and promoting more 'environmentally-sensitive' and 'sustainable' land 
use planning and development practices through a combination of regional growth management and urban intensification strategies. It situates the development of the City's of Ottawa's new 'smart growth' urban environmental policy and planning framework in the context of on-going political economic transformations at multiple scales and explores the implications of the City's urban intensification strategy for housing affordability in Ottawa's downtown core, where market-driven high-density condominium development has been most intensely targeted. 


\section{ACKNOWLEDGEMENTS}

This research was financially supported by an Ontario Graduate Scholarship and by a Michael Hare Fellowship, Irene Ethel Cockburn Bursary, and Ina Hutchison Memorial Bursary from the Department of Geography and Environmental Studies at Carleton University.

I would like to express my sincere gratitude to all of the participants in this research project. Special thanks go to Bob Brocklebank, Chair of Ottawa's Federations of Citizens Associations (FCA); People for a Better Ottawa (PBO) Coordinator, Jenny Gullen; Linda Hoad, Board Member for the Hintonburg Community Association, Heritage Ottawa, and the Ottawa Community Housing Corporation; and, Rebecca Aird of Sustainable Living Ottawa East (SLOE) for their perspectives, guidance and enthusiasm throughout the field research process. I am also sincerely grateful to Alain Miguelez, Jack Ferguson and Stan Wilder in the City of Ottawa's Planning and Growth Management Department for their time, energy and openness.

I am especially thankful to my thesis co-supervisors. During the formative stage of my doctoral program, Dr. Fiona Mackenzie inspired my theoretical interest in, and engagement with, poststructural political ecology and social nature scholarship. As my doctoral studies aroused a shift from rural studies in Sub-Saharan Africa to the geographies of Canadian cities, Dr. Fran Klodawsky helped me to navigate the vast and complex terrain of critical urban geographic scholarship and the challenging process of field research and dissertation writing with patience, understanding and care.

To my partner Nigel and son Jeremy, and to my aunt Cecilia, words cannot express my gratitude for your daily encouragement, gentleness and patience. Your steadfast support and 
unshakeable faith made the completion of this thesis possible. Finally, to my dearest friends, old and new, I extend my heartfelt thanks.

This dissertation is dedicated to my dad, Eugene Adamo, who instilled in me, at a very young age, a love of learning and a flair for the political. He departed the earth in 2008, but would be most proud of this accomplishment. 


\section{TABLE OF CONTENTS}

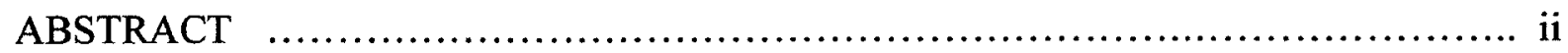

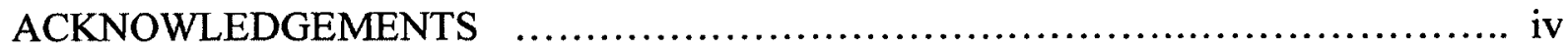

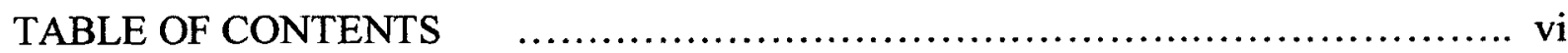

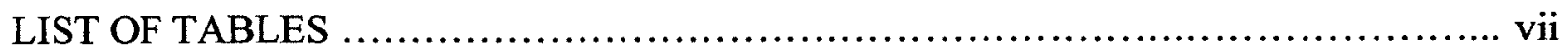

LIST OF ILLUSTRATIONS ......................................................... vii

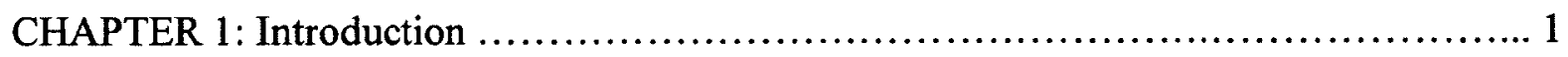

CHAPTER 2: Neoliberalizing sustainability, sustaining neoliberalism?: Theorizing 'sustainability' from an urban political ecology perspective....................... 18

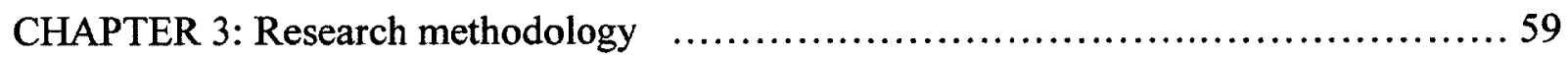

CHAPTER 4: The neoliberalization of Ontario planning in a period of provincialmunicipal restructuring, 1990-2001................................ 76

CHAPTER 5: The 'rolling out' of a new 'smart growth' planning regime in Ontario ..... 108

CHAPTER 6: Smart growth intensification and the 'greening' of urban governance:

The City of Ottawa, Canada............................................... 161

CHAPTER 7: Intensifying Inequality?: Smart growth intensification as 'policy-led' gentrification in Ottawa's inner urban area ............................ 208

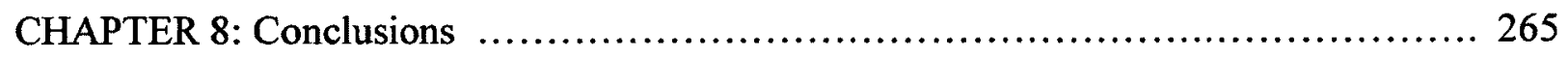

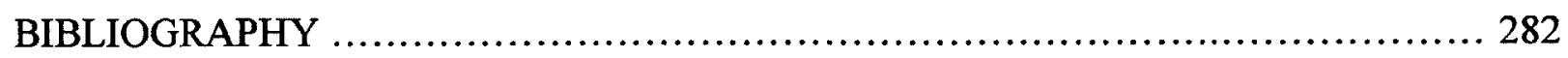

APPENDIX List of Interviews ..................................................... 298 


\section{LIST OF TABLES}

Table 7.1 Average home prices in Ottawa, 1995-2002 ..............................2230

Table 7.2 Average home prices in downtown Ottawa, 2000-2003 …................... 233

Table 7.3 Intensification Targets for Traditional and Arterial Mainstreets .............. 236

Table 7.4 2031 Density targets for the Central Area and Mixed Use .................... 237 


\section{LIST OF ILLUSTRATIONS}

Figure 5.1 Save Don't Pave the Oak Ridges Moraine. Earthroots .................... 112

Figure 6.1. Map of Sub-Areas, City of Ottawa. .................................... 169

Figure 6.2 The City of Ottawa's Official Plan, Schedule B, Urban Policy Plan............ 173

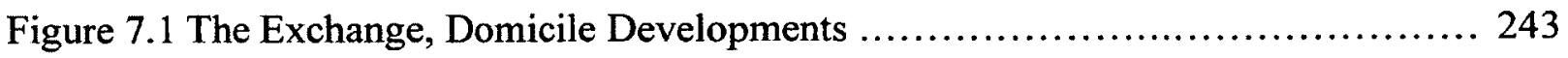

Figure 7.2 Promotional sign for Hudson Park condominium complex.................... 245

Figure 7.3 The Currents, Windmill Developments ................................. 246

Figure 7.4 CCOC's Beaver Barracks development in downtown Ottawa .................253

Figure 7.5 Oblate lands in the neighbourhood of Old Ottawa East .....................260 


\section{Chapter One}

\section{Introduction}

In recent years, municipal governance in Canada has undergone dramatic transformation. In an era of intense political economic restructuring and reform at different spatial scales, the rolling back of national state regulation, the retrenchment of public finance, the devolution of senior government responsibilities to local municipalities and the triumph of a 'growth first' neoliberal ideology (Peck and Tickell 2002) have produced a discernable shift towards more entrepreneurial and competitive styles of urban governance through which municipal governments have sought to actively mobilize city space to attract increasingly mobile capital investment in order stimulate (and sustain) urban competitiveness and secure long-term economic growth (Brenner and Theodore 2002, p.21; Keil 2002; Kipfer and Keil 2002; Smith 2002; Boudreau et al. 2009).

In particular, transformations to the urban built environment have become prominent features of urban entrepreneurialism, albeit in contextually specific ways, the world over. The creation of new privatized spaces for elite consumption, the construction of large-scale megaprojects to attract corporate investment, and the rolling forward of public policy in support of new market-driven residential development to stimulate the physical and economic revitalization of downtown spaces in order to attract professionally skilled labour and investment back to the city, are among the strategies deployed by local governments to strengthen urban economic competitiveness (Brenner and Theodore 2002; Keil 2002; Kipfer and Keil 2002; Smith 2002; Swyngedouw et al. 2002; Weber 2002). Consistent with broader processes of political economic restructuring, the neoliberalization of urban governance and policy has, unfortunately, gone hand in hand with a retreat from political engagement and policy development on issues of social 
redistribution, equity and inclusion. As a result, the 'urbanization of neoliberalism' (Brenner and Theodore 2002, p.20) is now responsible for new (or, at the very least, intensifying existing) patterns of vulnerability, inequality and social-spatial polarization in cities throughout the world.

The neoliberalization of urban governance and policy regimes, however, comes at a time when local governments are also facing growing public demands, not to mention a growing number of international environmental commitments, to protect and preserve local and regional environments, as well as the global biosphere, from the kind of predatory 'growth first' development agenda driving the current era of municipal policymaking (Keil and Desfor 1996; Keil and Graham 1998; While et al. 2004; Bunce 2004; Raco 2005). The pollution of air and water systems, non-renewable energy dependence, rising greenhouse gas emissions, and the loss of agricultural land, forests and other critical, life sustaining ecologies to unbridled urban and regional growth have become key elements of a new 'global-local' urban environmental politics in Canadian municipalities, as elsewhere across the planet.

At first glance, as While et al. (2004, p.550) observe, the rise of neoliberal urban governance regimes and 'growth-first' approaches to planning and development appear discursively and materially at odds with ideas of 'sustainability' defined in terms of 'ecological limits, intra- and intergenerational equity, the integration of social and environmental priorities, and widening involvement in decision-making'. However, a growing body of critical urban scholarship has begun to interrogate the 'sustainability' problematique vis-à-vis the advance of neoliberalism and capitalist urbanization processes (Escobar 1996; Raco 2005; Gunder 2006; Gibbs and Krueger 2007; Keil 2007). Far from opposed, as Keil (2007, p.46) insists, ideas of environment and sustainability have become integral to 'the survival of capitalism'; rather than challenge the fundamentals of capitalist urban development, sustainability has been 'redefined as 
one of the possible routes for a neoliberal renewal of the capitalist accumulation process'. Recent debate and empirical research in the field of urban political ecology (UPE) draw particular attention to the troubling ways in which ideas of nature, environment and sustainability, mobilized via politics of 'ecological modernization' (Hajer 1995), map onto contemporary neoliberal urban governance and policy transformations (Dixon and Dupuis 2003; While et al. 2004; Bromley et al. 2005; Bunce 2004, 2009; Raco 2005; Gibbs and Krueger 2007; Jonas and While 2007; Keil 2007). Whether to internalize and manage the inherent ecological contradictions and crises of earlier restructuring efforts (such as air pollution, resource depletion, or environmental degradation) or to promote positive urban environmental externalities as part of an aggressive entrepreneurial strategy to attract capital investment and labour to city spaces - for example, through policies promoting waterfront revitalization, the remediation of brownfield sites, 'green development', and pedestrian-friendly neighbourhoods - this work raises difficult and timely questions about how (and in whose interests) ideas of urban environmental 'sustainability' are being defined and 'taken up' in different urban contexts, regulatory environments and institutional landscapes, and with what consequences, both in terms of environment and social justice. These questions lie at the very heart of this thesis' examination of the City of Ottawa's 2003 Official Plan and, more specifically, its 'smart growth' urban environmental policy framework intended to curb low density 'sprawl' and promote more 'sustainable urban development' across the city region.

\section{The 'crisis' of sprawl}

In Canadian cities today, 'sprawl' is a dirty word. Municipal officials, city planners, journalists, environmentalists, social activists, and everyday people on the street - 'everyone is against urban 
sprawl' (Bourne 2001, p.26). Over the last decade, a broad consensus has emerged concerning urban growth and development in Canadian cities: 'our cities, as they have grown over the last 60 years, are contributing significantly to global and regional environmental problems, government deficits and social inequality' (CMHC 2005, p.1).

Since World War II, suburbanization has radically transformed the socio-ecological landscape of Canada's urban regions. Although there were suburbs prior to 1946, the era of large-scale suburbanization and suburban living has been a product of the post-war economy (Harris 2004; Smith 2006; Sewell 2009). Though driven, in part, by demographic change and a shift in middle class consumer preferences towards large single family, detached dwellings outside the city centre (made possible by the ascendance of the private automobile in the midtwentieth century), (sub)urban housing markets and development practices in Canada have also been highly conditioned by public policy - from provincial and municipal land use planning, to massive government-sponsored transportation infrastructure projects (particularly highways building) and taxation policies and incentives favouring new-built home purchase in suburban subdivisions (Haider and Tomalty 2009; Sewell 2009). As a consequence of nearly six decades of low density suburban growth, Canada's population has not simply become increasingly urbanized, it has become essentially (sub)urbanized. Between 1951 and 2001, Canada's urban population increased by approximately 16 million, a threefold increase that accounts for 95 percent of the country's total population growth. Most of this growth, however, occurred on the margins of existing cities, in their suburbs (Smith 2006, p. 211).

Today, an overwhelming majority of Canadians live in cities and their surrounding suburbs; Canada has indeed become a (sub)urban nation. Despite the triumphalism that has accompanied the growth of modern cities (and so-called 'mega-cities') worldwide, explosive 
growth in the suburban and exurban fringes of Canada's rapidly growing city regions - often pejoratively referred to as 'sprawl' - has become an object of considerable public policy attention in recent years. Although few agree on a shared definition of 'sprawl', in everyday planning vernacular it refers to the outward (and ostensibly unplanned) expansion of a city's margins to accommodate new low-density suburban residential and commercial development. In the context of public and political debate, sprawl is associated with the proliferation of relatively homogenous, low density, single-family suburban housing development, the spread of development onto local agricultural lands and sensitive natural environments (including forest and wetland ecologies), the fragmentation and/or destruction of wildlife habitats and the risk of biodiversity loss, increased automobile dependency and traffic congestion, deteriorating air quality and global climate change, as well as intensifying housing inequality, social-spatial segregation and burgeoning municipal expenditure on infrastructure and services (Bourne 2001; Wolch et al. 2004; Neuman 2005). In a word, sprawl has emerged as a kind of socioecological 'crisis' in Canadian cities, ranking high on political agendas in Canadian urban policy and planning communities at the beginning of the $21^{\text {st }}$ century.

\section{'Smart growth' and the $21^{\text {st }}$ century 'sustainable city'}

The crisis of sprawl has given rise to a progressive shift in Canadian urban policy and planning communities focused on curbing low density suburban growth and encouraging more 'sustainable' development practices in Canada's urban regions (Keil and Graham 1998; Bunce 2004, 2009; Lehrer and Weiditz 2009). As in other North American and European cities, the language of 'sustainability' has become common vernacular among municipal officials and planners, saturating the field of urban policy, planning and development practice in recent years. 
As, Layard (2001, p.1) observes 'land use planning and sustainable development seem to be ever more inextricably intertwined. References to the ideas, principles and policies underpinning sustainability are everywhere - from planning policy guidance to good practice guides to inclusion in development plans'.

Inspired by the smart growth, new urbanism, and city regionalism movements in the United States and Europe, which 'take as axiomatic that a compact city is more sustainable than sprawl' (Neuman 2005, p.12), 'urban sustainability' has been interpreted to imply a reconfiguration of urban growth patterns towards more compact, higher density, mixed use, transit and pedestrian oriented urban development through regional growth management and urban intensification strategies. Although recent empirical studies unsettle widely held assumptions about the relationship between compactness and urban sustainability (see Neuman 2005), smart growth urban intensification and growth management policies have been embraced at all levels of policymaking in Canada.

Beginning in 2001, the federal government released a series of policy statements and guidelines, as well as new sources of 'green' municipal funding to encourage smart growth inspired regional and urban planning reforms in Canadian provinces and municipalities (Government of Canada 2002; NRTEE 2003a, 2003b). In the Province of Ontario, new legislation and amendments to Ontario's Provincial Policy Statement, Planning Act and Municipal Act have been enacted over the last several years to curb sprawl through a combination of growth management, urban intensification and revitalization, and environmental protection measures in Ontario municipalities and their surrounding regions. Since then, Canadian municipalities have adopted an array of land use planning and development policies, for example, to establish urban growth boundaries intended to contain premature suburban 
expansion; direct and concentrate future urban growth within a city's existing built landscape; encourage denser, mixed-use development through urban intensification (e.g. brownfield remediation, property redevelopment and urban infill) and as part of new suburban 'greenfield' development; and promote alternative transportation options through government investment in public transit, cycling and pedestrian infrastructure.

Presently, smart growth-inspired land use planning and development policies form the centerpiece of official plans in many of Canada's largest urban centres, including the cities of Vancouver, Toronto, Montreal and Ottawa, with municipal officials and planners triumphant about the merits of smart growth as a $21^{\text {st }}$ century approach to 'sustainable' city building. Higher density, mixed use urban development practices, it is promised, hold the potential to conserve agricultural land and natural ecologies at a city's margins and are more energy efficient, less polluting, and inherently more environmentally 'sustainable' and socially 'livable' because residents can live closer to employment, shopping, and recreation, making walking, cycling and public transit more attractive and viable alternatives to the private automobile. Moreover, given the potential for compact urban development to promote more diverse and affordable housing choices and support investment in public transit, planners and policymakers also make the case that smart growth urban intensification practices constitutes a more socially equitable and inclusive alternative to traditional patterns of low-density suburban development (for example, see NRTEE 2003a, 2003b). On these grounds, smart growth planning reform experiments, in municipalities across Canada, have been routinely presented to the public as the single best (and perhaps only) approach to building more environmentally sustainable and socially just urban communities. 
Superficially at least, the shift towards smart growth-inspired urban policy and planning reform in Canadian municipalities, framed within the socially and environmentally progressive language of 'sustainability', appears out of step with recent waves of political economic restructuring at the federal and provincial levels and the neoliberalization of municipal governance and policy regimes in Canada over the last two decades. The retrenchment of Canada's national welfare state beginning in the late 1980 s, followed by dramatic provincialmunicipal restructuring in Ontario from the mid-1990s onward, led to massive cuts in federal and provincial spending and the eventual 'downloading' of key provincial responsibilities for urban infrastructure and services - including affordable housing, public transit, and municipal water and sewer infrastructure - to local governments by the end of the decade (Graham and Phillips 1998; Keil 2002; Fischler et al. 2004; Boudreau et al. 2009). Given the already limited fiscal capacity of Ontario municipalities, local governments have shifted towards more competitive and entrepreneurial governmentalities that actively promote urban competitiveness and economic growth over the development of socially and environmentally progressive alternatives to neoliberal forms of capitalist urbanization. The recent triumph of urban neoliberalization, not unexpectedly, raises important questions about how ideas of urban environmental 'sustainability' are being integrated into urban policy, planning and development practices in Canadian cities and with what social and ecological implications.

\section{Research question}

This thesis adopts an urban political ecology perspective to examine the rise of 'smart growth' as a new urban environmental policy regime in Canada and situates this in relation to broad discourses of 'sustainability' and 'livability' that have come to dominate recent urban 
debate and policy development in Canadian municipalities. Using the City of Ottawa, Ontario, as a case study, the thesis builds on, and endeavours to contribute to, an emerging body of scholarship attentive to the complex ways in which ideas of nature, environment and sustainability 'coincide, collide, articulate and even constitute' (Heynen et al. 2007, p.9) recent and on-going neoliberal governance and policy transformations at different scales, in diverse urban and regional contexts, and in complex and dynamic institutional and regulatory environments (Keil and Graham 1998; Kipfer and Keil 2002; Dixon and Dupuis 2003; While et al. 2004; Bromley et al. 2005; Bunce 2004, 2009; Raco 2005; Gibbs and Krueger 2007; Jonas and While 2007; Keil 2007). In an era of provincial-municipal restructuring and local governance change, this thesis critically examines how ideas of sustainability have been integrated into the City's of Ottawa's 'smart growth'-inspired urban environmental policy agenda and regional planning framework in the context of its 2003 Official Plan. The implications of Ottawa's urban intensification strategy for housing affordability in Ottawa's downtown core, where market-driven high-density urban development activities have been most intensely targeted, is given particular attention. The empirical research presented here is guided by the following questions:

1. In an era of intense political economic restructuring at multiple scales, when municipalities are shifting towards more entrepreneurial and competitive styles of urban governance, how is 'smart growth' defined in the City of Ottawa's 2003 Official Plan and supporting intensification policies and how have discourses of 'sustainability' and 'livability' been mobilized by City officials, planners and other actors to justify a shift towards a smart growth-inspired urban environmental policy agenda? 
2. How has the City of Ottawa's policy of 'smart growth' urban intensification been implemented since the adoption of the 2003 Official Plan, how is it transforming Ottawa's built environment (and broader socioecological landscape), and what are its potential implications for housing affordability (and social equity and inclusion) in Ottawa's downtown and in adjacent neighbourhoods undergoing significant residential intensification?

The first question focuses on the politics of 'smart growth' as a new urban environmental policy and planning agenda in the City of Ottawa. How is 'smart growth' being defined and implemented in an era of intense political economic restructuring and municipal governance reform? On what grounds is 'smart growth' justified as a new urban environmental strategy? By whom? To what ends? Whose interests are served by the City's smart growth intensification policies and whose are not?

The second question interrogates how Ottawa's 'smart growth' agenda and intensification policies have been put into practice 'on the ground', how they 'actually exist', and how they are actively transforming Ottawa's built environment in ways that matter to residents living in target neighbourhoods. In particular, it examines the complicated relationship between municipal policy and market driven housing development practices and considers the potential impact of new private sector-led high-density condominium development on housing affordability in Ottawa's urban core. Ultimately, it questions who gains and who loses from the socioecological transformation implied by the City of Ottawa's approach to smart urban intensification. 
Taken together, these research questions produced two main lines of inquiry. The first involved a critical examination of the City of Ottawa's 2003 Official Plan and supporting intensification policies implemented since the Plan's adoption. Since municipalities fall under the jurisdiction of the provinces in Canada, the City of Ottawa's new smart growth urban policy agenda is examined in relation to recent 'smart growth' planning reforms in the Province of Ontario and larger processes of provincial-municipal restructuring shaping municipal governance and policy change in Ontario cities since the early 1990s. This component of the research relied extensively on critical analysis of municipal and provincial policy documents, archival records and interviews with elected officials and planners with the City of Ottawa.

Situated in this broader context of political economic transformations initiated by senior levels of government and the neoliberalization of urban governance in Ontario cities, particularly since the mid-1990s, the second line of inquiry entailed an analysis of new high density urban development practices approved as part of the City's residential intensification strategy since 2003. The research probes the kinds of residential development produced through intensification, the nature of public and political debate surrounding new high rise condominium development in Ottawa's urban core, who benefits and who loses from intensification and, more specifically, the impact of this policy shift on housing affordability in downtown neighbourhoods undergoing significant intensification and revitalization. This component of the research involved analysis of housing market data for the City of Ottawa between 2003 and 2010, annual development reviews produced by the City of Ottawa, as well as interviews with local real estate developers, nonprofit affordable housing providers, and community associations representing neighbourhoods undergoing intensification. 


\section{Key arguments}

Based on this study of smart growth-inspired planning reform in the City of Ottawa, this thesis advances three broad and mutually reinforcing theoretical arguments. The first is that City of Ottawa's new 'sustainability' agenda and smart growth urban environmental policy reform experiment must be situated in broader processes of political economic restructuring and governance change at different scales. In particular, this thesis advances the argument that this new urban environmental policy regime has been highly conditioned by provincial-municipal restructuring and reform processes, initiated by the Conservative Harris government in Ontario in the mid-1990s, and the shift towards an increasingly competitive and entrepreneurial approach to municipal governance in Ottawa in recent years. In this political economic context, I argue, the City's smart growth planning framework and residential intensification policies have been geared toward both reducing growth-related municipal spending by directing future residential and commercial development to Ottawa's existing built environment where city infrastructure and services are already available and stimulating the physical and economic revitalization of Ottawa's downtown and surrounding urban districts as part of a larger effort to boost Ottawa's competitiveness and sustain long-term economic growth. In this respect, the thesis argues that 'smart growth' has played a key part in the rolling out of a new wave of neoliberal urbanization in the City of Ottawa.

Second, the thesis develops the argument that, consistent with the logics of urban neoliberalization, the City of Ottawa's downtown revitalization through intensification policy experiment is premised upon a 'growth first' approach to urban development that privileges the imperatives of urban competitiveness and economic growth over those of social equity and redistribution. Specifically, in the absence of policies requiring that new high density urban 
development include the provision of affordable housing, I argue that municipal support for new market-driven intensification projects constitutes a form of 'third wave' or 'policy-led' gentrification (Hackworth and Smith 2001) with the potential to erode housing affordability, intensify patterns of inequality and exclusion, diminishing rather than enhancing the 'livability' and 'sustainability' of Ottawa's revitalized downtown and the city region as a whole.

Third, and more broadly, in contrast to dominant narratives of 'sustainability' as a universally accepted norm and a policy, planning and development goal that serves undifferentiated 'public good', this thesis advances the argument that sustainability is an inherently political discourse and practice. Specifically, I argue that municipal governance and policy change, in an era of intense urban neoliberalization, have involved the selective incorporation of environmental goals that advance the broad imperatives of competitiveness and growth. Given the strategic alignment of municipal 'smart growth' intensification policies and private sector real estate development practices in the City of Ottawa, this thesis asserts that 'sustainability' is not always (or perhaps ever) socially just, but rather, appears deeply implicated in the production of an increasingly uneven and deeply unjust urban socioecological landscape.

\section{Structure of the thesis}

Chapter One introduces the research problem and the research questions that have guided the empirical and theoretical development of this dissertation.

Chapter Two explores recent theorizing in the field of UPE and other complementary scholarly literatures that have informed the intellectual development of this dissertation. The chapter begins by examining recent theoretical insights and empirical contributions from the field of UPE that help to elaborate an understanding of urbanization as a process of social- 
ecological transformation that is shaped by a complex and dynamic web of political, economic, social and ecological relations and processes operating at different spatial scales. The chapter goes on to explore insights from a growing body of urban geographical literature on neoliberalism and neoliberalization. It engages with recent theoretical debates that elaborate a view of neoliberalization as a socially produced, historically and geographically specific process that is always produced within particular national, regional and local milieus, defined by inherited institutional frameworks, policy regimes, regulatory practices, and political struggles. Of particular relevance to this thesis is recent scholarship that draws particular attention to the ways in which broader processes of neoliberalization are becoming actively internalized within contemporary urban governance, policy and planning regimes - what Brenner and Theodore (2002) refer to as the 'urbanization of neoliberalization' (Brenner and Theodore 2002; Peck and Tickell 2002). The chapter concludes with a discussion of recent scholarly work that has begun to draw attention to the complex ways in which discourses of 'sustainability' are being actively incorporated into urban policy and planning regimes and local development practices as part of a shift towards increasingly entrepreneurial and competitive modes of urban governance in an period of dramatic political economic restructuring at multiple scales.

Chapter Three outlines the methodology developed and used to conduct the research that informs this dissertation. The chapter begins with a brief overview of the study's research objectives, followed by a discussion of the rationale supporting the use of a qualitative research methodology. The remainder of the chapter elaborates the specific methods used, and methodological challenges encountered, in this research project. Given the strong policy focus of the research, documentary analysis constitutes the core of the research methodology. However, semi-structured interviews and participant observation were critically important methods both to 
triangulate and reinforce data collected through the review and analysis of documentary materials and to explore ideas, issues and themes that could not be gleaned through documentary review alone.

Chapter Four critically examines provincial planning reform experiments in the Province of Ontario between 1991 to 2001 . The aim of this chapter is to explore the broad context of political economic restructuring and governance change that gave rise to a new 'smart growth' inspired planning regime in Ontario (the focus of Chapter 5). The argument developed in this chapter is that 'smart growth' planning reform experiments in the Province of Ontario, since 2001 , have been highly conditioned by, and made to serve, this larger provincial-municipal restructuring agenda by successive provincial governments.

Chapter Five explores the emergence of smart growth planning reforms in the Province of Ontario, beginning in 2001 , and situates this policy transformation with broader processes of provincial-municipal political economic restructuring and retrenchment in Ontario since 1995. In an era of intense neoliberalization, the chapter argues that provincial planning reform in Ontario, premised on a shift towards compact, mixed use, and 'sustainable' urban development, appears to constitute a tactical response on the part of the Ontario provincial government to ensure that urban growth becomes as efficient and cost effective as possible, in order to reduce financial pressures on already fiscally-constrained municipalities while also attempting to manage the environmental and public health risks, and subdue the fierce public contestation, increasingly tied to 'sprawl' . But more than this, the chapter develops the argument that this new planning regime, espousing the protection of Ontario's unique urban and regional environments and the promotion of development patterns that support the creation of more 'vibrant', livable' and, ultimately, 'sustainable' cities, has also been mobilized as part of an aggressive entrepreneurial 
strategy through which the provincial government has sought to bolster the economic competitiveness of Ontario cities and, in this respect, has been constitutive of a new wave of urban neoliberalization across the province.

Chapter Six examines the City of Ottawa's 'smart growth' urban enviornmental policy and planning framework that forms the basis of the City's 2003 Official Plan. It critically analyzes how discourses of urban 'sustainability', 'livability' and economic competitiveness have been deployed by municipal government and other actors to justify a shift away from dominant patterns of low density suburbanization, characteristic of preceding decades, towards a new municipal planning regime premised on higher density, mixed use urban development across the city region. Far from challenging, much less advancing alternatives to, the foundations and features of capitalist urbanization, this chapter advances the argument that the City of Ottawa's Official Plan and its 'smart growth' policy framework internalize many of the features of contemporary neoliberal governmentalities, policies and development practices that privilege the goals of urban competitiveness and economic growth, eclipsing issues of social and environmental justice central to more progressive discourses of urban environmental 'sustainability' (Haughton 1999; Gibbs and Krueger 2007; Keil 2007; McCann 2007). Specifically, the research that informs this thesis suggests that the City's smart growth intensification strategy appears ultimately concerned with stimulating the physical and economic revitalization of Ottawa's city centre as a means to attract capital investment and professionally skilled labour and sustain the growth of Ottawa's expanding knowledge-based economy.

At a time when the City of Ottawa has adopted a increasingly entrepreneurial approach to urban growth and development, Chapter Seven explores what 'smart growth' means for social equity and inclusion in the city region. It examines how Ottawa's smart growth intensification 
policies have transformed patterns of urban development in the city region, especially in Ottawa's downtown and inner urban neighbourhoods where the City's revitalization through intensification strategy has been spatially targeted. The chapter develops the argument that the City's policy of urban intensification appears ultimately geared toward facilitating new upscale, high rise condominium development, suggesting a close alignment between municipal public policy and market-driven development practices in Ottawa's urban core. Set against the City of Ottawa's goals to improve access to affordable housing in the city region, as defined in its Official Plan, the chapter suggests that the City's intensification mandate, as it has been conceived and implemented to date, has done little to increase Ottawa's affordable housing stock through the private housing market and, as such, appears to constitute a form of 'third wave' policy-led gentrification (Hackworth and Smith 2001) with the potential to intensify inequality and patterns social-spatial exclusion, and diminish the 'livability' and long-term 'sustainability of the city region.

Chapter Eight provides a brief review of key arguments and insights presented in this thesis, including its empirical and theoretical contributions to the field of urban political ecology, and identifies potential avenues for future empirical research and theoretical examination. The chapter concludes with a brief discussion of the potential contribution of the thesis' research findings to on-going public debate and policy development processes in the City of Ottawa and, perhaps, other municipalities experimenting with smart growth urban policy and planning reforms across Canada. 


\section{Chapter Two}

Neoliberalizing sustainability, sustaining neoliberalism?:

Theorizing 'sustainability' from an urban political ecology perspective

\section{Introduction}

In the last decade there has been an explosion of critical urban scholarship that seeks, in different ways, to reinsert questions of nature, environment and sustainability into urban debate. The research and analysis that informs this dissertation draws from, and makes contributions to, recent theorizing in the field of urban political ecology but also incorporates ideas and insights from a number of complementary scholarly literatures. This chapter begins by examining recent theoretical insights and empirical contributions from the field of urban political ecology that help to elaborate an understanding of urbanization as a process of socioecological transformation that is shaped by a complex and dynamic web of political, economic, social and ecological relations and processes operating at different spatial scales. Given the power of political-economic restructuring in shaping contemporary processes of social and ecological change, this chapter goes on to explore and reflect on insights from a growing body of urban geographic literature on contemporary neoliberalism and 'neoliberalization'. Specifically, I examine recent theoretical debates that elaborate a view of neoliberalization as a socially produced, historically and geographically specific process that is always produced within particular national, regional and local milieus, defined by inherited institutional frameworks, policy regimes, regulatory practices, and political struggles and which, more than ever before, has become internalized within contemporary urban policy and planning regimes (Brenner and Theodore 2002; Peck and Tickell 2002). The chapter concludes with a discussion of recent scholarly work that has begun to show the complex ways in which discourses of 'sustainability' are being actively incorporated into 
urban policy and planning regimes and local development practices as part of a shift towards increasingly entrepreneurial and competitive modes of urban governance in an period of intense political economic restructuring at multiple scales.

\section{Urban political ecology: Conceptualizing urbanization as a process of socioecological transformation}

Urban political ecology (UPE) is a recent body of academic scholarship that builds on existing work in political ecology. The field of political ecology first emerged in the 1970s as a reaction to the limitations of research on land-use, resource management and environmental conservation without adequate consideration of local and global political economy (Peet and Watts 1996). Building on the seminal work of Blaikie (1985) and Blaikie and Brookfield (1987), political ecology is defined, in the broadest sense, as an analytical approach combining issues of ecology with 'a broadly defined political economy' (Blaikie and Brookfield 1987 cited in Peet and Watts 1996, p.4). In its early incarnations, political ecology was most closely aligned with scholarly work in the field of international development focused on agricultural and rural struggles associated with the management and conservation of marginal or fragile environments in the global south and how these are situated in and transformed by complex webs of historical, cultural and political-economic relations unfolding across multiple scales (see for example, the essays in Peet and Watts 1996). Rather than view environmental problems as the result of resource scarcity, population growth or ignorance, political ecology focuses instead on the restructuring of political economies, ecologies, and cultures in different regions of the world and how these transformations are shaping contemporary struggles over the allocation, use, and management of land, forest, water and other environments, landscapes and resources (Peet and Watts 1996, p.4). By the 1990s, political ecology had blossomed into a large, diverse and 
complex field of inquiry. Inspired by ideas from Marxist political economy, environmental history, postructuralism, feminist studies and gender theory, as well as critical theories of science, political ecology has branched off in a number of new directions such that it has become a remarkably rich and diverse empirical and analytical terrain (Peet and Watts 1996, p.9).

In recent years, the geographies of political ecology have expanded considerably. The vast majority of political ecology research during the 1990 s centered on studies examining the complex and historically changing social, cultural and political economic relations, institutions, and processes shaping environmental change and conflict in rural areas of Latin America, Africa and Asia. Recent scholarship, however, seeks to broaden political ecology's geographical purview to include the industrialized societies of the global North (see for example, McCarthy 1998, 2002, Heynen 2003; Kaika 2005; Schroeder et al. 2006; Swyngedouw and Heynen 2003; Wainwright 2005; Young and Keil 2005). In his analysis of the American 'wise use" movement, James McCarthy $(1998,2002)$ was perhaps the first to apply the insights and tools of political ecology to examine contemporary environmental politics in the North. McCarthy argues that virtually all of the core themes of political ecology are relevant to the study of resource and environmental conflicts in North America and, more broadly, in the advanced economies of the (post-)industrial North. Expanding the geographies of political ecology, according to Wainwright (2005, p. 1033), advances the field in at least three ways. First, the study of (post-)industrialized environments expands political ecology's scope into problems that are responsible for some of the world's gravest ecological changes, from air and water pollution to more recent global issues like climate change. Second, expanding political ecology to include the geographies of the global North complicates notions of marginality, ecological management, and the place of nature in contemporary social-ecological change and conflicts. Finally, this shift opens up new questions 
about the relationships between spatiality, regions, and the ways we frame and interpret contemporary environmental conflicts and processes of environmental and social change (ibid).

Certainly, bringing political ecology 'home from the tropics' (Latour 1993, p. 100) offers exciting new analytical and political possibilities. It creates space for examining the particularities of political ecological struggles in relation to the complex, historically changing, and deeply uneven geographies of (post-)industrialized economies and environments. But, as Wainwright (2005) cautions, it is crucial that we think critically about the geographies of political ecology. The shift towards a 'first world' political ecology, he argues, risks concealing and reinforcing the 'imaginative geographies' of north and south, first and third world, rural and urban, that frame and often seriously limit our understanding of environmental conflict as 'events that happen in discreet places that are defined in advance' (ibid, p.1035). Building on the seminal work of Edward Said, Wainwright argues that simply transferring a research framework from one space, place, region or landscape to another risks treating the 'first world', and 'cities' for that matter, as a self-evident spaces, and in-so-doing risks undermining what is, in Wainwright's view, most radically political about political ecology - that is, to examine the ways in which 'conflicts over nature always already entail struggles over the constitution of the world and its spaces' (ibid, 1039). They are, in Said's (1994, p.7) words, 'struggles over geography'.

In a recent turn, the analytical and empirical terrain of political ecology has also broadened to include uniquely urban geographies and the pressing concerns, conflicts and injustices associated with urban environmental change in different parts of the world. For the most part, early work in political ecology and related scholarship focused almost exclusively on rural and 'wild' environments, with little attention directed to 'the urban' as a site and process of socioecological transformation. Academic and political debate about 'global' environmental 
problems such as deforestation, desertification and climate change have also routinely ignored the urban origin of many of these global issues (Heynen et al. 2006, p.2). At the same time, much of the urban studies literature has concentrated on the social, cultural and political-economic drivers and consequences of capitalist urbanization with comparatively little consideration of the 'physical-environmental foundations on which the urbanization process rests' (ibid). However, in a rapidly urbanizing world where the majority of the planet's population will soon live in cities (including the world's rapidly growing 'mega-cities'), ignoring urbanization as a process of significant socioecological change seems shortsighted, if not perilous.

The lack of substantial intellectual and political engagement between political ecology and urban studies, until recently, appears symptomatic of what Latour (1993) describes as modernity's 'great divide' between nature and society in which the two have, historically, been treated as ontologically and epistemologically distinct domains. Particularly in societies of the industrialized North, 'nature' is seen as that which is external to society, culture and urban life. This separation of society and nature is both pervasive and problematic. As Swyngedouw and Heynen (2003, p. 906) observe, 'urbanization has long been viewed as a process whereby one kind of environment - namely the "natural environment" - is traded for, or rather taken over by, a much more crude and unsavoury "built" environment'. Keil and Graham $(1998$, p.102) take a similar position, arguing that '[c]ities are built in nature, with nature, and through nature, yet so often appear to be external and opposed to nature. "Nature" has become viewed as that which is outside cities, yet is everywhere in cities (as parks, electricity or even automobiles). Nature is continuously remade in cities at the same time as it is taken to be destroyed by cities'. Cities have long been considered not simply opposite but opposed to nature; urbanization is posited as a process that compromises, replaces, and even destroys natural environments (ibid). Over the 
last several decades, this view of urbanity as external (and opposed) to nature has become virtually hegemonic and foundational to contemporary environmental politics and political movements. As Harvey (1996) explains,

This predominant anti-urbanism is as odd as it is pernicious. It is almost as if a fetishistic conception of "nature" as something to be valued and worshipped separate from human action blinds a whole political movement to the qualities of the actual living environments in which the majority of humanity will soon live. It is, in any case, inconsistent to hold that everything in the world relates to everything else, as ecologists tend to do, and then decide that the build environment and the urban structures that go with it are somehow outside of both theoretical and practice consideration. The effect has been to evade integrating understandings of the urbanizing process into environmentalecological analysis (Harvey 1996, p.427)

Recent theorizing of nature-society relations, however, has begun to unsettle conventional understandings of nature as separate from society as well as the prevailing view of cities and urbanization as somehow unnatural, even anti-ecological spaces and processes, and thus outside the purview of political ecological inquiry. For Harvey,

... in a fundamental sense, there is nothing unnatural about New York City and sustaining such an ecosystem even in transition entails an inevitable compromise with the forms of social organization and social relations which produced it. To term New York City as a "created ecosystem" may sound somewhat odd. But human activity cannot be viewed as external to ecosystemic projects. ... The long history of urbanization is, after all, one of the most significant of all processes of environmental modification that have occurred throughout recent world history. ... It is fundamentally mistaken, therefore, to speak of the impact of society on the ecosystem as if these are two separate systems in interaction with each other. The typical manner of depicting the world around us in terms of a box labeled "society" in interaction with a box labeled "environment" not only makes little intuitive sense ... but it also has just as little fundamental theoretical and historical justification (ibid, p.186-187).

Building on theorizing in Marxist political economy, including the seminal works of Neil Smith (1984) and David Harvey (1996), and more recent political ecology and 'social nature' scholarship (for examples, see Castree 1995; Braun and Castree 1998; Castree 2001; Braun 2002; Whatmore 2002), UPE takes as its starting point that nature is socially produced, rather 
than a pure entity that exists apart from society, culture and urbanity. As Swyngedouw and Heynen observe, '[c]ontemporary scholars increasingly recognize that natural or ecological conditions and processes do not operate separately from social processes, and that the actually existing socionatural conditions are always the result of intricate transformations of pre-existing configurations that are themselves inherently natural and social' (Swyngedouw 1999 cited in Swyngedouw and Heynen 2003, p.907, emphasis in original).

Over the last decade, the literature on 'social nature' has advanced a path-breaking, if at times controversial, perspective that unsettles the peculiarly modern notion of a world divided a world in which nature and society are thought to be separate and distinct spheres - that has been central to the grand project of the Enlightenment and the separation of natural and social sciences, and physical and human geographies. Though the distinction between society and nature is so familiar and fundamental as to seem unquestionable, this growing body of scholarship explores the extent and ways in which "nature has never been simply "natural"" (Castree 2001, p.5). In this regard, Castree explains that social nature theorizing regards two ideas as axiomatic. The first is that whether one is speaking of wilderness, resources, natural hazards, or the human body, the natures we inhabit are 'made' in different ways, at different levels, and with a multitude of social and ecological consequences (ibid). The second is that the tendency of taking nature to be self-evident, as a domain defined as pre-given, asocial and unchanging, risks perpetuating dominant patterns of power, inequality and injustice in the world - in Braun's (2002, p.17) words, 'taking nature as commonsense risks concealing and reinforcing the relations of power that are constitutive of, and internalized within, nature's historical forms of legibility'. Inspired by Marxist, feminist, poststructural, postcolonial, and science studies perspectives, recent theoretical and empirical contributions to the growing body of social nature 
literature offer critical insight into the array of historical and discursive practices that constitute 'nature' as an object of knowledge and political calculation and how these go on to shape our interventions in, and material transformation of, 'nature' in the early $21^{\text {st }}$ century.

Understanding nature as socially produced, quite crucially, has important analytical and political implications. As Braun so poignantly argues, ' $[\mathrm{t}]$ he notion that nature is socially constructed, rather than a pure identity external to society, forces us to take responsibility for how this remaking of nature occurs, in whose interests, and with what consequences (for people, plants and animals alike). It brings together ecology and social justice' (Braun 2002, p.13, emphasis in original). More specifically, it allows us to see, as Harvey's (1996) observations suggest, that there is nothing unnatural about produced environments - cities, dammed rivers, and farmers' fields are all the outcome of historically-specific socioecological transformations and, as such, fall squarely in the purview of political ecological inquiry.

Recent UPE scholarship draws much inspiration from the theorizing of Neil Smith (2008 [1984]) who first advanced the argument that society, in the form of modern industrial capitalism, was quite literally 'producing nature' in the narrow interests of capitalist development. Although the idea that nature is socially produced can be traced back to the writings of Marx, Smith's Uneven Development develops, more explicitly, the argument that the social 'production of nature' is intimately tied to processes of uneven development under capitalism. Working from a Marxist political economy perspective, Smith observes,

The production of nature not only provides a rather philosophical foundation for discussing the uneven development of capitalism, but it is a very real result of the development of this mode of production. What jars us so much about this idea of the production of nature is that it defies the conventional, sacrosanct separation of nature and society, and it does so with such abandon and without shame. We are used to conceiving of nature as external to society, pristine and pre-human, or else as a grand universal in which human being are but small and simple cogs. But here again our concepts have not 
caught up with reality. It is capitalism which ardently defies the inherited separation of nature and society and with pride rather than with shame (2008 [1984], p.7).

For Smith, the conventional view of nature as separate from humanity - 'a thing, the realm of extra human objects and processes existing outside society' (2008 [1984], p.11) - is entirely meaningless. The relationship between society and nature, he argues, 'is a historical product and even to posit nature as external to society $\ldots$ is literally absurd since the very act of positing nature requires entering into a certain relationship with nature' (ibid, p.32). But, more than this, Smith insists that the idea of external nature is deeply problematic precisely because it belies the ways in which capitalist development has, from the very beginning, depended upon the material transformation of nature. In this respect, for Smith, ideas of 'external nature' function as 'ideological' (and, hence, political) to the extent that they serve to conceal, or at least legitimate, 'the process by which nature is made increasingly internal to the dynamics of capitalist accumulation' (Castree 2001, p.191, emphasis in original).

Following Marx, Smith's 'production of nature' thesis advances a 'dialetical' understanding of the relationship between nature and society, one in which 'nature is mediated through society and society through nature' (Smith 2008 [1984], p.33). In the Marxist tradition of historical-geographical materialism, Smith explains, this mediation is conceived as a 'metabolism' in which the labour process is considered foundational to the metabolic interaction between society and nature (ibid). At its simplest, the metaphor of socioecological metabolism is meant to convey the idea that, to survive, all livings things transform 'nature' and, as an outcome of this process, 'both humans and nature are changed' (Swyngedouw and Heynen 2003, p.903). According to Swyngedouw (2006, p.24), the social production of nature refers to 'the metabolic process that is energized through the fusion of the physical properties and creative capacities of 
humans with those of non-humans. For Marx, this is what defines the act of "labouring" ... the purposeful metabolic process intended to produce and reproduce (human) life.' More specifically, UPE scholars advance the view that the outcome of socioecological transformations - that is to say, the kinds of 'social natures' that are produced (if only contingently) - are shaped by a complex array of social relations that are both historically and geographically specific. As Heynen et al. (2006, p.7-8) explain, '[t]o the extent that labour constitutes the universal premise for human and metabolic interaction with nature, the particular social relations through which this metabolism of nature is enacted shape the form this metabolic relation takes. ... Social relations operate in and through metabolizing the "natural" environment and transform both society and nature'.

Under capitalist social relations, in particular, the social production of nature is bound up with the production of use and exchange values wherein 'nature' is transformed into a 'commodity'. Commodities, it is argued, constitute forms of 'metabolized socio-natures', produced through the mobilization of capital and labour 'with an eye toward the realization of the embodied exchange value' (Heynen et al. 2006, p.8). As Castree (1995, p.19-20) observes, 'the imperatives of capitalism bring all manner of natural environments and concrete labor processes upon them together in an abstract framework of market exchange'; capitalism 'commodifies whole landscapes, constructs and reconstructs them in particular (profit motivated) ways'. For proponents of UPE, the re-engineering of rivers, the making of an urban park, or the construction of a skyscraper speak to the particular social relations through which socio-natural metabolisms are produced and mobilized towards the accumulation of wealth within the political economy of capitalism (Heynen et al. 2006, p.8). 
Crucially, understanding nature as always socially produced is deeply significant because it makes it possible to see that ' $[T]$ here is nothing a priori unnatural about produced environments like cities, genetically modified organisms, dammed rivers, or irrigated fields' (Heynen et al. 2006, p.11). Urban environments are built in and through 'nature', produced through a complex web of relations and processes that are simultaneously ecological and social. As a consequence, urbanization takes on new meaning. No longer conceptualized as a process that destroys or replaces 'nature', UPE advances an understanding of urbanization as 'a particular sociospatial process of metabolizing nature, of urbanizing the environment' (Swyngedouw 2004, p.8). Although metabolic transformations of nature are in no way unique to cities, for proponents of UPE, now more than ever, 'it is on the terrain of the urban that this accelerating metabolic transformation of nature becomes most visible, both in its physical form and its socioecological consequences' (Swyngedouw and Heynen 2003, p.907).

UPE's approach to urban metabolism understands contemporary urban socionatural landscapes as produced through 'interwoven knots of social process, material metabolism and spatial form' (Swyngedouw and Heynen 2003, p.906, emphasis in original). As Keil and Boudreau (2006, p.42) observe, studies of urban metabolism are not new, having gained prominence during the 1960s following the publication of Abel Wolman's (1965) 'The metabolism of cities'. Early studies of urban metabolism drew critical attention to the flows of water, energy, food, building materials, everyday consumables, and waste (to name but a few) in and out of cities - flows that are local, regional and increasingly global in scale - and that make urban life possible. While insightful in terms of quantifying the 'urbanization of nature', Swyngedouw (2006, p.35) argues that the ostensibly uncritical 'industrial ecology' perspective used to chart the material flows of nature (often through crude input-output modeling), 'fails to 
theorize the process of urbanization as a social process of transforming and reconfiguring nature'. More specifically, Keil and Boudreau (2006, p.43) observe that beyond reference to specific policy changes, early studies of urban metabolism offer little by way of analysis of how political and economic transformations shape processes of urban socioecological change and, as a result, avoid 'fundamental critique' of the political economy of capitalism. They also point to a relative lack of critical examination of social processes, including modes of regulation and consumption patterns, and a tendency to treat 'nature' as more or less static, as strictly material flows with an unchanging character and devoid of agency in processes of socioecological transformation (ibid).

The emerging field of UPE expands on this early body of work but takes as its starting point that socioecological transformations and the 'urban natures' to which they give rise are historically and geographically specific and produced through a complex array of dynamic and power-laden relations and processes that are simultaneously material and discursive, economic and political, social and cultural. In particular, UPE is attentive to the ways in which the social production of urban environments, in different historical and geographical milieus, has become internal to the functioning of the global capitalist political-economic system. A growing body of political ecological scholarship, for example, explores the production of nature under contemporary forms of neoliberalism or 'neoliberal capitalism' (Heynen and Robbins 2004, p.6). Contributions to two special issues of Capitalism, Nature, Socialism in 2005, for example, examine the political ecologies of nature in an era of accelerating neoliberalization, with specific attention directed to issues of environmental governance, the privatization of natural resources, the enclosure of nature and resources and the exclusion of communities that depend on these everyday environments, and the valuation of nature as a commodity under neoliberal forms of 
capitalism (also see McCarthy and Prudham 2004; Prudham 2004). The subsequent publication of Neoliberal Environments: false promises and unnatural consequences, edited by Heynen et al. (2007), further speaks to the growing body of theoretical and empirical scholarship concerned with the effects of neoliberal policy transformations on environmental governance and its implications for social justice both in terms of environmental quality and in terms of equality in access to the environments and resources - water, land, forests, air - on which the lives of everyday people, in different regions of the world, depend in a multitude of different ways. Although this scholarship is not entirely focused on the urban as a site and scale of empirical research and analysis, it grapples with many of the issues that are germane to current UPE research concerning the social production of 'urban natures' in an era of neoliberal governance, policymaking and development practice.

Over the last decade, the field of UPE has produced theoretically and empirically rich real-world case studies and analyses that seek to reinsert questions of nature, environment and sustainability into urban debate and academic scholarship. The terrain of recent UPE research covers themes as diverse as the political ecology of contemporary suburbanization (Keil and Graham 1998), the production of North American suburban lawnscapes and the political economy of the lawn chemical industry (Feagan and Ripmeester 1999; Robbins and Sharp, 2003a, 2003b, 2006), the political ecology of urban forests and parks (Heynen 2003); the production, regulation and privatization of urban water regimes (Swyngedouw 2004, 2005; Kaika, 2005, 2006; Young and Keil 2005; Loftus 2006; Smith and Ruiters 2006), the political ecology of urban air pollution (Veron 2006), 'unnatural disasters' in urban landscapes (Martin 2009), urban warfare (Graham 2006); and, research and analyses of 'urban hunger' (Heynen et al. 2006) and 'obe-city' (Marvin and Medd 2006) as particular configurations of bodily and 
urban socioecological relations tied to the production, consumption and politics of food in cities in different regions of the world. This growing body of scholarship interrogates how, and in whose interests, particular urban natures, environments and landscapes are produced; the uneven relations of power through which such urban socioecological transformations take place; and, ultimately, the consequences of contemporary urban environmental change both in terms of ecology and social (in)justice and (in)equality in today's cities.

Specifically, building on critical urban theorizing, recent contributions to UPE seek to elaborate a better understanding of socioecological urbanization vis-à-vis contemporary processes of 'uneven geographical development' (Smith 2008 [1984]). As Brenner and Theodore (2002, p.8) explain, capitalist development has always been associated with 'a distinctive, historically specific geographic landscape in which some places, territories and scales are systematically privileged over and against others as sites for capital accumulation'. Ideas of uneven development have become central to urban geographical research over the last decade, yet this work has, for the most part, focused on the social forms, dynamics and consequences of urban change, failing to capture, adequately, the ways in which uneven development simultaneously takes ecological forms in cities (Heynen et al. 2006, p.9). Recent studies in urban political ecology draw attention to the ways in which, for example, contemporary processes of political economic restructuring have produced, and continue to produce, spatially differentiated, highly uneven and deeply unjust urban environments and landscapes (see, for example, Keil and Graham 1998; Heynen 2003, 2006; Keil and Desfor 2004; Swyngedouw 2004; Marvin and Medd 2006; Veron 2006). As Heynen et al. (2006, p.10) observe, 'in the context of urban environmental change, it is likely that urban areas populated by marginalized residents will bear the brunt of negative environmental change, whereas other, more affluent parts of cities enjoy 
growth in or increased quality of environmental resources'. This growing body of scholarship takes as its starting point that the production of urban environments and natures is not independent of, but rather mediated by, gender, class, ethnicity, race and other social struggles in contemporary cities (ibid).

As both an analytical and political project, UPE places questions of power, justice and inequality at the centre of research and analysis by interrogating 'who gains and who loses (and in what ways), who benefits and who suffers from particular processes of [urban] socioenvironmental change' (Heynen et al. 2006, p.10). From the perspective of UPE, then, 'there is no such thing as an unsustainable city' (ibid). Rather, urbanization is viewed as a process of socioecological transformation, shaped by relations of power (often at multiple scales), responsible for the production of new environments and new natures that benefit some social groups (differentiated by gender, class, ethnicity, race) while, at the same time, producing new (or intensifying existing) patterns of exclusion, displacement and inequality. The production of urban environments is, therefore, regarded as a highly contested and contestable terrain wherein questions of socioecological 'sustainability' are ultimately political questions about the kinds of urban environments we wish to build and inhabit. In this respect, UPE has the potential to advance a more progressive socio-environmental politics. As a political project, Heynen et al. (ibid, p.13) argue that the intent of urban political ecology is 'to enhance the democratic content of socio-environmental construction by means of identifying the strategies through which a more equitable distribution of social power and a more inclusive model of the production of nature can be achieved'. 


\section{The neoliberalization of urban governance, policy and planning}

One particular cluster of urban political ecology scholarship especially germane to this research project draws from, and has made valuable contributions to, recent theorizing of neoliberal urbanization. Whereas most accounts of contemporary urban change in North American cities focus on the social and political crises brought about by political economic restructuring and the institutional responses and spatial strategies employed by urban policy regimes, bringing a political ecology perspective to analyses of urbanization reveals the crucial ways in which ideas of 'nature', 'the environment' and 'sustainability' have become highly influential in the rolling out of recent waves of neoliberal urban governance reform and restructuring, in both discursive and material ways. Before considering how broad processes of neoliberalization and urban political-economic restructuring intersect ideas of nature, environment and sustainability in contemporary urban governance, politics and policymaking, I first examine recent theoretical explorations and new critical approaches to understanding contemporary neoliberalism from the field of urban geography.

\section{Critical perspectives on neoliberalism and neoliberalization}

Recent theoretical and empirical work in and beyond the discipline of urban geography has begun to highlight the challenges that current waves of neoliberalism pose to its conceptualization. There is considerable agreement, certainly, regarding the basic elements of neoliberalism as an ideological project. Neoliberal ideology, Brenner and Theodore $(2002, \mathrm{p} .2)$ explain, is grounded in the belief that 'open, competitive and unregulated markets, liberated from all forms of state interference, represent the optimal mechanisms for economic development'. Though neoliberalism's intellectual roots are traced to the postwar writings of Freidrich Hayek 
and Milton Friedman, Brenner and Theodore observe that it gained widespread prominence during the late 1970 s and early 1980 s as 'a strategic political response' to the global recession of the earlier decade:

Faced with the declining profitability of traditional mass production industries and the Keynesian welfare policies, national and local states throughout the older industrialized world began, if hesitantly at first, to dismantle the basic institutional components of the postwar settlement and to mobilize a range of policies intended to extend market discipline, competition, and commodification throughout all sectors of society. In this context, neoliberal doctrines were deployed to justify, among other projects, the deregulation of state control over major industries, assaults on organized labour, the reduction of corporate taxes, the shrinking and/or privatization of public services, the dismantling of welfare programs, the enhancement of international capital mobility, the intensification of interlocality competition, and the criminalization of the urban poor (Brenner and Theodore 2002, p.3).

Although these constitute the basic features of neoliberalism, recent scholarship offers a more nuanced reading of neoliberalism as a process that is 'neither monolithic in form nor universal in effect' (Peck and Tickell 2002, p.36). For both analytical and political reasons, this work challenges the pervasive view of neoliberalism as a kind of ' naturalized, external force', as static, 'disembodied', 'out there' (ibid p.35-36). Politically, the treatment of neoliberalism as both asocial and ahistorical is considered highly problematic precisely because it masks the world of power relations that allow it to appear as a self-evident and all-encompassing 'reality'. As Peck and Tickell (ibid) argue, dominant discourses of neoliberalism are 'self-actualizing', to the extent that the free market is presented as the most 'natural' basis on which to organize society and economy and, in this respect, is seen to be both inevitable and necessary. Neoliberalism, they assert, constitutes a 'strong discourse', a desocialized and dehistoricized theory, that 'makes itself true' in part because of its self-actualizing quality - camouflaged as a set of objective, natural and technocratic truths - and in part because of its intimate alignment with contemporary forms of political-economic power (ibid). Theorizing neoliberalism as a 
process is intended, at least in part, to decenter its hegemonic status, creating spaces within which neoliberalism may be challenged and contested and alternative socio-cultural, political economic, and urban imaginaries produced (Leitner et al. 2006; Keil 2002).

Analytically, reconceptualizing neoliberalism in processual terms is intended to capture the subtle transformations, over the last several decades, in its institutional forms, its political rationalities, and its economic and social consequences and the ways in which these have been unevenly and inequitably reproduced from place to place (Brenner and Theodore 2002; Peck and Tickell 2002). Taking cues from debates on globalization, Peck and Tickell (2007, p.27-28) advance a more nuanced, 'grounded' conceptualization of 'neoliberalization' as 'a socially produced, historically and geographically specific, crisis-driven, conjunctural and definitionally incomplete phenomenon'. While the replication and diffusion of contemporary neoliberalism in different regions across the world suggests an underlying and persistent 'metalogic', neoliberalization is conceptualized as a process that is simultaneously 'out there' and 'in here', the effects of which - political, economic, social, and ecological - are always spatially variegated and uneven (Peck and Tickell 2002, p.36).

Specifically, Peck and Tickell (2002) point to significant internal shifts, over the last few decades, in the institutional arrangements, political rationalities, types and targets of restructuring, and economic and social consequences of neoliberalization processes. They distinguish, for example, between the era of 'roll-back neoliberalism' of the 1980s and 1990s, identified as a period of intense state restructuring and retrenchment in which governments, particularly in North America and Western Europe, introduced a constellation of austerity measures including often-dramatic cuts in spending on public services and infrastructure, in many cases transferring responsibility for these to lower levels of government, and the more 
recent wave of 'roll-out neoliberalism' which, since the late $1990 \mathrm{~s}$, has been characterized by a new, and highly interventionist, phase of state-building, regulatory reform and other policy experimentation, intended to manage the myriad social, economic, and ecological contradictions, consequences and crises of earlier restructuring and reform experiments. As Peck and Tickell (2002, p.37) explain:

In this course of this shift, the agenda [of neoliberalism] has gradually moved from one preoccupied with the active destruction and discreditation of Keynesian-welfarist and social-collectivist institutions (broadly defined) to one focused on the purposeful construction and consolidation of neoliberalized state forms, modes of governance, and regulatory relations. It is this more recent pattern of institutional and regulatory restructuring, which we characterize here as a radical, emergent combination of neoliberalized economic management and authoritarian state forms that demands both analytical and political attention. ... In this process, forms of "shallow" neoliberalization - during the Thatcher/Reagan years - that were understood by many at the time as a moment of destructive and reactionary "antiregulation" might now need to be confronted as a more formidable and robust pattern of proactive statecraft and pervasive "metaregulation".

In recognition of the serious limitations and contradictions of earlier manifestations of roll-back neoliberalism - not the least of which included pervasive market failures, new forms of social polarization and environmental devastation, and a dramatic intensification of uneven development at all spatial scales - the most recent phase of 'roll-out' neoliberalism is characterized by a deeply interventionist policy agenda in which new discourses of social and environmental reform, and new institutions and modes of policy development and program delivery are emerging around issues such as crime, immigration, policing, welfare and workfare programming, urban order and surveillance, urban revitalization, and environmental regulation (ibid, p.42). Rather than address the systemic failures and inequalities produced by earlier neoliberal policy experiments, roll-out neoliberalism is read as a strategic and aggressive 'reregulation, disciplining and containment of those marginalized or dispossessed by the 
neoliberalization of the $1980 \mathrm{~s}^{\prime}$ (ibid). Without denying the existence of an underlying 'metalogics' of neoliberalism - the common set of discourses and practices shaping policy development and implementation in the post-Keynesian era - Peck and Tickell's periodization begins to highlight the historically and geographically variegated and highly unstable character of contemporary 'neoliberalism'. The intent is not, however, to suggest that neoliberalism can be neatly analyzed as a series of discrete phases or historical periods as this risks concealing the fluid, overlapping, hybrid nature of contemporary neoliberalization processes that, as Peck and Tickell later argue (2007, p.33), draw from and mobilize, simultaneously and iteratively, elements of both roll-back and roll-out forms of neoliberal discourses, modes of governance, and policy priorities. However, Heynen et al. (2007, p.4) caution that such distinctions may nonetheless prove inadequate to capture 'the temporal and spatial evolution and adaptation of governance projects that, even if inspired by neoliberal orthodoxies, are transformed in the messiness of politics, lived experiences and actual geographies'.

Building on Peck and Tickell's understanding of neoliberalization as a process, Brenner and Theodore's (2002) concept of 'actually existing neoliberalism' likewise draws critical attention to the 'contextual embeddedness' of neoliberal restructuring processes which are always produced within particular 'national, regional and local contexts defined by the legacies of inherited institutional frameworks, policy regimes, regulatory practices, and political struggles' (Brenner and Theodore 2002, p.4). In contrast to neoliberal ideology, which holds that the 'free market' operates according to immutable laws irrespective of geography or history, 'actually existing neoliberalism' suggests a plural and processual understanding of neoliberalization as a 'historically specific, on-going, and internally contradictory process of market-driven socio-spatial transformation, rather than a fully actualized policy regime, 
ideological form or regulatory framework' (ibid, p.6). 'Actually existing neoliberalism' attends to the ways in which political-economic restructuring, operating across multiple spatial scales, always materializes in particular, partial and provisional ways within contextually-specific institutional landscapes, policy environments and social-cultural milieus. Far from a complete, coherent, and comprehensively conceptualized (and universally implemented) political project, explorations of 'actually existing neoliberalism' draw critical attention to, rather than conceal, the reality that such projects are 'always pragmatic and opportunistic, that involve muddling through and experimentation, that the targets for urgent "reform" [are] selectively identified and that reform imperatives [are] translated in contextually-specific ways' (Peck and Tickell 2007, p.30).

While it is true that neoliberalizations are producing new and increasingly pervasive forms of uneven development at multiple geographic scales, recent critical scholarship also insists that neoliberal capitalist restructuring be understood as an always unstable, deeply contested and contestable process (Peet and Watts 1996; Heynen et al. 2007; Leitner et al. 2007). Leitner et al. (2007) argue, for example, that if neoliberalism is never imposed in a pure form but rather always emerges in historically and geographically specific ways, in and through particular politico-institutional and socio-cultural contexts, its articulation is always particular, partial and incomplete, creating spaces for resistance and contestation of many kinds. As such, they insist, 'it is not sufficient to study neoliberalism's rise to hegemony by theorizing neoliberalization itself. Contextualizing neoliberalism is important, but it is also necessary to examine its articulation with contestations within and beyond the state that have shaped and will continue to influence its conditions of possibility' (ibid, p.8). They suggest that greater theoretical attention must be given to the multiple and complex contestations that seek to rework, dismantle or 
replace neoliberalism in particular places and historical moments, yet caution against perspectives that begin with neoliberalism itself and regard contestation as secondary and reactive since ' $[\mathrm{t}]$ aking the internal logic of neoliberalism as the starting point risks essentializing it'. Rather, they see greater analytical and political possibility in research that decenters neoliberalism by 'conceptualizing neoliberalization and contestation as coimplicated, and contestation as exceeding neoliberalism'. They go on to explain, '[c]ontestations have their own histories and spatialities, involving not only localized initiatives but also interurban, local-global, north-south, and urban-rural connectivities'. Approaching neoliberalization and contestation as constituted in and through the other, avoids reproducing and reinforcing essentialized and reified images of both.

Not unexpectedly, reconceptualizing neoliberalizations(s) as socially produced, historically and geographically contingent and contested processes has significant epistemological, methodological and political implications. A critical and comprehensive inquiry into the geographies of actually existing neoliberalism requires an examination of the different, place-specific processes of neoliberalization and their concrete, everyday manifestations through historically and geographically sensitive, 'context-contingent analyses' (Sparke 2006 cited in Heynen et al. 2007, p.4). This entails critical qualitative studies that examine neoliberal political projects and their contextually specific interactions with inherited frameworks, institutional practices, political environments, and on-going social and political struggles as they 'actually exist' in particular cities, national landscapes, and regions of the world. Since '[t]he topography of neoliberalization is always shifting', Peck and Tickell $(2007$, p.35) argue that the goal of such a critical research program is not "convergence on a standardized neoliberal "norm"'. Rather, case studies of particular neoliberal formations are understood to constitute 'points on this 
landscape that ... are no more or less than historically and geographically specific conjunctures in which neoliberal features necessarily and inescapably coexist with other state and social forms' (ibid). From a political ecology perspective, as Heynen et al. $(2007$, p.12) observe, 'the theoretical and methodological commitments to grounded engagement with actual places, people and ecologies in political ecology provide a powerful way to check the idealist tendencies of neoliberal discourses and ideologies'. Not only does such a research program create opportunities to produce finely grained, contextually-specific analyses, it serves to underscore the inescapably contingent, political, and contestable character of neoliberalization, unsettling its hegemonic status and creating political space for exploring more socially equitable and ecologically sustainable alternatives to contemporary forms of neoliberal capitalism.

\section{The urbanization of neoliberalism}

Recent scholarship elaborating a critical geographic perspective of neoliberalization underscores that while processes of neoliberalization are multiscalar in their unfolding and in their social, economic and ecological effects, they are occurring with particular intensity in cities and their surrounding regions (Harvey 1996, 2000; Brenner and Theodore 2002; Keil 2002; Kipfer and Keil 2002; Peck and Tickell 2002; Smith 2002; Leitner et al, 2007; Boudreau et al. 2009). As Brenner and Theodore (2002, p.28) observe, cities have become so central to the 'reproduction, mutation and continual reconstitution of neoliberalism' that a discernable 'urbanization of neoliberalism' is taking place across the globe, as 'cities become the strategic targets for a broad range of neoliberal policy experiments, institutional innovations, and politicoideological projects'. In an era of globalization, they argue, 'cities are embedded within a highly uncertain geoeconomic environment characterized by monetary chaos, speculative movements of 
financial capital, global location strategies by major transnational corporations, and rapidly intensifying interlocality competition'. Cities have responded to growing political-economic uncertainty 'by engaging in short-termist forms of interspatial competition, place-marketing, and regulatory undercutting in order to attract investment and jobs' (ibid, p.20). At the same time, more than two decades of government deregulation and dismantlement, involving the retrenchment of national welfare regimes and the downloading of responsibilities for the provision of public infrastructure, programs and services from senior levels of government to local municipalities, have imposed severe fiscal constraints on cities, leading to major budgetary cuts in spending at a time when urban poverty, homelessness and other social inequalities and conflicts have intensified under neoliberalism.

In part a tactical response to the expansion and entrenchment of neoliberalization at other spatial scales, cities have adopted increasingly neoliberalized modes of governance highlighting the insidious ways in which "neoliberal programs have been directly "interiorized" into urban policy regimes' (Brenner and Theodore 2002, p.20). Although processes of 'neoliberal localization' are necessarily place-specific, unfolding in diverse forms and combinations within particular local and national contexts, transformations in urban governance are part and parcel of contemporary neoliberal urbanization (ibid, p.21). In contrast to the Keyensian era of urban managerialism, urban forms of governance have become entrepreneurialized under contemporary neoliberalization. As Swyngedouw et al. (2002, p.201-202) explain, 'the ascent of a more assertive, dynamic, entrepreneurial style of urban governance' is marked by 'the gradual shift away from redistributive policies, welfare considerations and direct service provision towards more market-oriented and market-dependent approaches aiming at pursuing economic promotion and competitive restructuring'. To attract investment and sustain long-term economic growth, 
local governments have imposed a 'shock treatment of deregulation, privatization, liberalization, and enhanced fiscal austerity' (Brenner and Theodore 2002, p.20-21). As part of this shift towards more entrepreneurial and competitive styles of urban governance, cites have become 'institutional laboratories for a variety of neoliberal policy experiments, from place-marketing, enterprise and empowerment zones, local tax abatements, urban development corporations, public-private partnerships, and new forms of local boosterism to workfare policies, property redevelopment schemes, business-incubators projects, new strategies of social control, policing and surveillance and a host of other institutional modifications within the local and regional state apparatus' (ibid p.21). The overarching goal of such neoliberal policy experiments has been to stimulate new urban development, attract business investment and sustain long-term competitiveness - in short, 'to mobilize city space as an arena for market-oriented economic growth and for elite consumption practices' (ibid).

While the imperative of mobilizing urban space towards market-driven capitalist growth constitutes the dominant political project for municipal governments, 'roll-out neoliberalism' has also established 'flanking mechanisms' and 'modes of crisis displacement' through which cities seek to manage the contradictions and crisis tendencies of neoliberalization processes - these include, for example, new local economic development policies, community-based programs to alleviate social exclusion, as well as a variety of new environmentally targeted programs and policies to mitigate the ecological effects of earlier restructuring and reform processes (Brenner and Theodore 2002, p.26-27; While et al. 2002). In other words, the social, political and ecological 'externalities' of earlier restructuring processes have become actively internalized, and redefined, in the rolling out of more recent waves of neoliberal urban governance and policymaking. 
A key component of this new mode of urban governance is a shift in urban planning policy and development practices with the goal of transforming a city's built environment to promote urban economic competitiveness (Keil and Desfor 1996; Kipfer and Keil 2002; Swyngedouw et al. 2002; Weber 2002; While et al. 2004; Mayer 2007; Lehrer and Wieditz 2009). Following decades of disinvestment, many cities have reacted to the decline of inner-city middle class populations and business commitment, through spatially targeted, market-driven urban development projects and revitalization schemes as vehicles through which local governments actively seek to increase municipal revenues, attract business investment and sustain long-term economic growth. In the aftermath of political economic restructuring in the 1980 s and early 1990 s, the devolution of senior government responsibilities to municipalities in Canada, as elsewhere, increased cities' dependence on own-source revenues, namely property tax revenues, to finance municipal infrastructure, programs and services making local governments more dependent on the private real estate market (Weber 2002, p.190). In this context, large-scale urban (re)development has emerged, albeit in place-specific ways, as a central strategy for revaluing urban land and increasing municipal revenues, enabling local governments to address the often-severe fiscal imbalance facing cities (Weber 2002; Swyngedouw et al. 2002).

In addition to expanding municipal revenues, urban property development has also become the centerpiece of a new, 'competitive city' policy and planning regime in many North American and European cities emphasizing city centre revitalization as part of an effort rebuild and expand downtown environments into flexible 'live/work' spaces for young urban professionals, upscale service and financial centres, and/or 'world class' hospitality and tourist destinations (Swyngedouw 2002; Bunce 2004; Mayer 2007; Lehrer and Wieditz 2009). 
'[E]mblematic examples of neoliberal forms of urban governance' (Swyngedouw et al. 2002, p.196), contemporary large-scale urban development and revitalization programs have been inspired, in significant measure, by Richard Florida's (2002) ideas concerning the significance of what he terms the 'creative class' in the new 'knowledge economy' - ideas that have become highly influential in $21^{\text {st }}$ century urban policymaking (Bunce 2004; While et al. 2004; Peck 2005; Gibbs and Krueger 2007; McCann 2007; Lehrer and Wieditz 2009). Florida insists that in today's knowledge-based global economy, urban competitiveness depends significantly on the ability of cities to attract business investment and stimulate industry growth by first attracting the right kind of people - flexible and mobile knowledge economy entrepreneurs who can locate anywhere in the world. Young, highly educated professionals, according to Florida (2002), are drawn to cities, particularly downtown city centres, that are eminently 'livable', boasting socially vibrant and diverse neighbourhoods, lively arts and cultural amenities, state of the art infrastructure, and an abundance of recreational and leisure environments. As part of this shift in urban policy, local governments and their planning departments are assigned the role of facilitating the physical transformation of downtown urban environments required to enable the kind of social and economic transformation explicated by Florida's 'creative city' argument (Cowen, 2004). Large-scale urban development projects such as luxury condominiums, office complexes, waterfront developments, 'historic districts', upscale mainstreet development, conference centres, and cultural, sports and entertainment facilities become 'the material expression of a developmental logic that views megaprojects and place marketing as means for generating future growth and for waging a competitive struggle to attract investment capital' (Swyngedouw et al. 2002, p.199). 
Although urban revitalization policies and large-scale development projects take distinct, contextually-specific forms in different cities, Swyngedouw et al. (2002, p.201) observe a discernible shift in which 'planners and local authorities adopt a more proactive and entrepreneurial approach aimed at identifying market opportunities and assisting private investors to take advantage of them'. In this new, neoliberalized urban policy environment, the goal of public policy is to facilitate market-oriented urban development by ameliorating conditions for private sector investment. According to Kipfer and Keil (2002, p.243), '[t]the proactive pursuit of real-estate investments through financial incentives, "deal-making", and megaprojects' and the expanding role of consulting firms, development corporations and 'publicprivate partnerships' in urban planning and development have become key features of local competitiveness policies. In conjunction with financial incentives intended to offset the perceived financial risks associated particular development types (for example, urban brownfields), local government support for large-scale urban development is also geared toward efforts to remove or bypass regulatory and other barriers to development by way of 'exceptionality' measures, such as the freezing of conventional planning tools; bypassing or amending restrictive bylaws, statutory regulations and institutional bodies; the creation of project agencies with special or exception powers of intervention and decision-making and/or change in national or regional regulations (Swyngedouw et al. 2002, p.196).

Recent urban scholarship goes a step further, advancing the argument that local government support for market-oriented urban development through urban revitalization policies and plans constitutes a form of 'third wave' gentrification (Hackworth and Smith 2001) in contemporary cities. According to Hackworth and Smith (2001), third wave gentrification is a complex urban process that defies any single definition as it now occurs at a variety of sites and 
scales, involves an array of possible actors, and takes many different, place-specific forms. Unlike gentrification processes of the 1980 s, 'third wave' gentrification is defined as a largely state-led (or 'policy-led') process wherein local governments actively court private sector realestate developers in urban development practices. For Smith (2002, p.443), what distinguishes third wave gentrification from earlier processes is that 'a new amalgam of corporate and state powers and practices has been forged in a much more ambitious effort to gentrify the city'. The literature on policy-led gentrification suggests that, in an increasingly neoliberalized urban governance and policy environment, urban revitalization has become the a cornerstone of urban entrepreneurial and 'revanchist' (Smith 1996) policies geared toward 'mak[ing] urban space safe, clean and secure' in order to attract and retain, investors, real-estate capital, and middle class and more affluent residents to city centres (Kipfer and Keil 2002, p. 237). Although policy-led gentrification practices, and their material outcomes, are highly place-specific, Smith (2002) argues that gentrification has quickly become a 'global urban strategy', deeply implicated in the geographies actually existing neoliberalism the world over. In step with Peck's (2005) theorizing of 'fast urban policy', Davidson and Lees (2005, p.1167) argue that a 'gentrification blueprint' is being 'mass-produced, mass-marketed and mass-consumed around the world'. In many cities, this blueprint has taken the shape of new build, residential high-rise condominium development in city centres and neighbouring mature suburbs (Davidson and Lees 2005; Bunce 2009; Lehrer and Wieditz 2009). Although often couched within the legitimating language of an 'urban renaissance' promising more 'inclusive' and 'socially mixed' patterns of urban development, recent urban scholarship from Britain, for example, suggests that the result of recent waves of urban revitalization has been gentrification and social exclusion in target neighbourhoods and the 
intensification of social-spatial polarization and inequality on an urban scale (Rose 2004; Davidson and Lees 2005; Lees 2008).

The imperative of 'sustainability' in an era of neoliberal urban governance and ecological modernization

Such path-breaking theoretical and empirical contributions concerning the "urbanization of neoliberalism' (Brenner and Theodore 2002, p.20) have gone on to inform recent debate and scholarship in the field UPE. In recent years, as While et al. (2004) observe, urban governance regimes in advanced capitalist economies have been forced to incorporate two seemingly contradictory sets of pressures into urban policy and planning agendas. As discussed above, processes of globalization and neoliberal political-economic restructuring at a variety of spatial scales have led local governments on a competitive quest to physically transform, 'rebrand', and market their built environments, particularly city centres, as part of an aggressive strategy to attract and retain mobile investment capital and skilled labour and to sustain long-term economic growth - a shift in policy and planning agendas that has proven to be a key component of new entrepreneurial and competitive styles of urban governance. Driven by a hard-line 'growth first' development politics (While et al. 2004, p. 549), the neoliberalization of urban governance, policy and planning has been responsible for creating new forms of social inequality and environmental exploitation that is anything but 'sustainable'. Yet, this shift in urban development politics has coincided with growing public demands on municipalities to protect the environment and promote 'sustainability', particularly as responsibility for international environmental commitments is increasingly passed to sub-national levels of government (ibid, p.549-550).

On the surface, While et al. (2004, p.550) argue that the ascendance of a neoliberal 'growth first' urban development politics, appears at odds, both discursively and materially, with 
the idea of 'urban sustainability' - that is, 'notions of ecological limits, intra- and intergenerational equity, the integration of economic, social and environmental priorities, and widening involvement in decision-making'. The scaling back of environmental regulations, cuts to government funding for environmental programs and remediation, and the proliferation of all sorts of negative environmental 'externalities' and injustices at different scales the world over, suggest a view of neoliberalization and environmentalism as contradictory sets of socioecological relations, processes, political priorities and policy goals. Yet, as 'environmental change and environmental politics have become arenas for debating the limits, costs and consequences neoliberalizations' Heynen et al. (2007, p.11) suggest that there is equal evidence of 'the power of neoliberal orthodoxies to circulate through and hybridize with environmentalism, comprising part of what makes neoliberalizations complex and variegated'. With this, recent critical scholarship has begun to move beyond examination of the environmental consequences of neoliberal reform and restructuring processes, important as this is, to consider 'the ways in which environmental governance, and environmentalism as a set of political movements, coincide, collide, articulate and even constitute the emergence of neoliberalism' (ibid, p.9, emphasis added).

Since the late $1980 \mathrm{~s}$, following the publication of the World Commission for Environment and Development's report Our Common Future (WCED 1987), 'sustainable development' has become a dominant and all-embracing 'meta-narrative' shaping policies, programs and development agendas at a variety of spatial scales, in both urban and rural environments, and in different regional contexts the world over (Meadowcroft 1999). In cities of North America and Europe, the language of 'urban sustainability' is everywhere and has become common vernacular among municipal officials and planners, saturating the field of urban policy, 
planning and development practice to the point where, as Layard (2001, p.1) observes, 'land use planning and sustainable development seem to be ever more inextricably intertwined'. While normative notions of sustainability and sustainable development advocate a balance of social equality, environmental protection and economic development in all planning and development decisions - what is, today, commonly referred to as 'the triple bottom line' (Brassoulis 1999) there has been a proliferation of critical scholarship on sustainable development as an inherently political and power-laden discourse that has been made to serve a variety of complex, often contradictory policy ends (see for example, Hajer 1995; Campbell 1996; Escobar 1996; Marcuse 1998; Burton 2000; Bauriedl and Wissen 2002; Neuman 2005; Raco 2005; Gunder 2006; Rast 2006; Gibbs and Krueger 2007; Jonas and While 2007; Keil 2007).

In contemporary urban policy and planning circles, sustainability has become 'a broadly accepted norm', a policy and planning objective that is argued to be 'in everybody's interest' (Bauriedl and Wissen 2002, p.109). Although, as Neuman (2005, p,17) observes, sustainability remains a 'fuzzy', vague term with a multitude of meanings, it has fast become 'a Platonic idea, a category of the good' in and beyond the field of urban policy. Claims of universality, however, are deeply problematic; they are, in Haraway's (1991) words, a 'god-trick' that denies the crucial link between power and knowledge. Concealing the socially produced and, therefore, inherently political and power-laden nature of 'sustainability' is troubling precisely because it places sustainability and the array of urban policies, planning discourses and development practices with which it has become associated, seemingly beyond the realm of politics and public challenge (Gunder 2006, p.213). As Gunder argues, 'If sustainability is unquestionably good, then sustainable cities must be good, as must sustainable management, sustainable regeneration, or sustainable development. Who can argue against sustainability and all that is associated with 
it?' (ibid). The idea of sustainability as a universally accepted norm and policy objective renders invisible the ways in which urban governance and policy are conditioned by larger, historically and geographically specific, political-economic transformations and socio-cultural contexts. It also, as Marcuse (1998, p.105) insists, masks the reality that urban policy and development are always deeply contested and 'conflict-laden arenas' mediated by gender, class, ethnicity, race and other axes of difference, wherein 'what benefits one, hurts another'. At a time when governments are rolling back redistributive policies in favour of more entrepreneurial and competitive modes of urban governance, the 'hegemonic crisis of unsustainability', in fact, appears complicit in rendering concerns about homelessness, racism and inequality secondary to neoliberal policy priorities (Gunder 2006, p.214).

Incorporating elements of poststructuralism into political ecological analysis, however, makes it possible to see sustainability as a historically-specific and socially produced discourse, an effect of power, rather than a disembodied, apolitical 'truth'. From a Foucaultian perspective, 'discourse is the articulation of knowledge and power, of statements and visibilities, of the visible and the expressible. Discourse is the process through which social reality inevitably comes into to being' (Escobar 1996, p.46). Foucault's analytics are ultimately concerned with the productivity of power; how through discourse, power produces particular effects of truth. For Foucault, power is something that is 'exercised', not simply held (Dreyfus and Rabinow 1982, 192). Exploring 'the how of power' (Foucault 1980, p.92) is about attending to how things show up in the world, how they become visible and intelligible in particular ways (and not in others) through an array of representational practices - scientific, technical, economic, political, cultural and so on - that enable us to build our accounts of the world. It is about questioning how things objects, concepts, models, theories, policies - 'show up in the world', how they are made visible, 
and how they obtain their status as 'fact' or 'truth' (Dreyfus and Rabinow 1982; Rajchman 1991; Latour 1993; Escobar 1996; Haraway 1997; Castree and Braun 1998; Braun 2002).

Visibility, for Foucault, is "one of the great "self-evidences" of power. Power becomes acceptable and tolerable through its spatialization or the way it is given to be seen. ... Power conceals itself by visualizing itself. Its workings become acceptable because one sees of it only what it lets one see, only what it makes visible' (Rajchman 1991, p.84). From this perspective ideas of 'nature', 'environment' and 'sustainability' show up in the world in particular, partial and provisional ways through the production of what Foucault terms 'spaces of visibility' (ibid). Foucault's genealogical method involves 'exposing how things are made visible, how things are given to be seen, how things are shown to knowledge or to power ... [the] ways in which things become seeable' and how they serve to 'constitute the subject' (ibid p.70). Quite crucially, for Foucault, discourse simultaneously involves the production of 'spaces of invisibility'; it involves both 'unconcealment' (bringing things into presence/visibility) and 'concealment' (excluding other possible appearances) (Castree and Braun 1998, p.18). Foucault's analytics is an art of exposing not only the range of historical and discursive practices that go into making things visible in specific ways, it is also an art of exposing the 'unseeable' and therefore 'unseen' (Rajchman 1991). Attending to the discursive fields in and through which things are made visible is crucial because representation begets intervention; the significance of discursive practices is that in making things visible in particular ways they become available to forms of political, economic and social calculation (Castree and Braun 1998, p.19). From this perspective, environmental policy issues like pollution, climate change or urban sprawl do not simply reflect a pre-existing 'reality', but rather are produced through discourse - that is, through socially and historically constituted sets of claims. The focus of political ecological inquiry, in turn, is to 
interrogate what these claims are, where they come from, how (and by whom) they are defined and mobilized as 'environmental problems' and become objects of particular forms of policy and development intervention, and with what social and ecological consequences.

Over the last two decades, 'sustainability', as a policy discourse, has been actively shaped by and incorporated into the political economy of neoliberalization at different spatial scales and towards a diversity of ends in many different parts of the world. As Raco observes (2005, p.329), sustainability has become 'a chameleon-like discourse which has been (re)interpreted and deployed by a range of interests to legitimate and justify a range of often contradictory and divergent agendas'. Specifically, Keil (2007, p.41) asserts, 'sustainability and ecological modernization ... are both complicit in a process through which [neoliberal] capitalist development has been increasingly linked to ecological concerns'. Following on these insights, the extent and ways in which sustainability, as a policy regime and development agenda, takes neoliberal forms has recently become an area of critical urban scholarship in and beyond the field of UPE.

Specifically, recent debate and empirical research in UPE have begun to examine how discourses of 'sustainability' are being incorporated into (and made to serve) urban governance, policy and planning agendas, in different cities, regulatory environments and institutional contexts, vis-à-vis the advance of neoliberalization (Dixon and Dupuis 2003; While et al. 2004; Bromley et al. 2005; Raco 2005; Gibbs and Krueger 2007; Jonas and While 2007; Keil 2007; Bunce 2009). A central theme emerging from this growing body of UPE scholarship is that the contours of urban governance change and sustainability policy development are being actively etched, in a multitude of contextually-specific ways, by the politics of 'ecological modernization' (Hajer 1995). Ecological modernization is defined by Hajer (ibid, p.26) as a discourse that 
acknowledges the structural origins of environmental problems but assumes that these issues can be internalized and managed within the existing political economy of (neoliberal) capitalism. Complex and inherently political environmental issues, like urban sprawl, are reduced to mere technical matters for scientists, planners and other 'experts' to resolve. The power of ecological modernization, as a discourse, Harvey $(1996$, p.378) argues, rests on 'its refusal to see a trade off between environmental issues and economic growth in zero-sum terms'. Ecological modernization is premised, instead, on the belief that investments in environmental remediation and protection can produce net economic benefits. In this respect, ideas of 'sustainability', Harvey insists, lie at the very heart of the contemporary 'win-win' politics of ecological modernization (ibid).

Not surprisingly, ecological modernization, as a policy discourse, has proved highly attractive to governments in advanced capitalist economies. As Hajer (1995, p.32) explains, ecological modernization offers 'a positive sum solution to what had previously been a zero sum problem'. It works within the boundaries of capitalism and conceptualizes environmental crises as a problem of 'inefficiency' without imposing serious restrictions on industry; in fact, under the discourse of ecological modernization, ecological crises pose no threat to capitalism but become 'a vehicle for its very innovation' (ibid). No longer conceptualized as an 'anomaly to modernity', Hajer (ibid, p.33) argues that ecological modernization is associated with a 'renewed belief in the possibility of mastery and control, drawing on modernist policy instruments such as expert systems and science'. By seeking to incorporate environmental considerations into government policy and development agendas, ecological modernization also constitutes a seductive political strategy to accommodate, assimilate or silence public dissent and contestation on pressing environmental issues - evidenced by the growing number of environmental 
organizations and advocacy groups, in different parts of the world, that strategically work within (rather than against) the politics of ecological modernization, 'sustainability', and 'sustainable development' to influence policy at different scales (Hajer 1995; Harvey 1996; Raco 2005).

Of particular significance to UPE inquiry into the incorporation of sustainability into urban governance regimes in different contexts is the work of While et al. (2004) on what they describe as the search for a 'sustainability fix' in the post-industrial British cities of Manchester and Leeds. Building on Harvey's concept of a 'spatial fix' as a state strategy intended to manage the inherent tensions associated with capitalist development processes, While and colleagues (ibid, p.551) argue that ' $[\mathrm{t}]$ he historically contingent notion of a sustainability fix is intended to capture some of the governance dilemmas, compromises and opportunities created by the current era of [neoliberal] state restructuring and ecological modernization'. Although the production of nature has always been a central feature of capitalist development and wealth accumulation practices (Smith 1984), they interpret sustainability policy initiatives as particular forms of ecological modernization situated within changing modes of urban governance in the United Kingdom. Based on evidence from Manchester and Leeds, While et al. (2004, p.551) contend that urban entrepreneurialism appears to increasingly rely on 'the active remaking of urban environments and ecologies'. Urban policy and planning interventions focused on river restoration, the remediation of old industrial brownfield sites, and even so-called 'ecoinvestment' in public transit systems, they suggest, 'have been significant not only in the reimaging of cities, but have also been important in opening up actual urban spaces for new waves of investment and bringing back the middles classes in the city or stabilizing working class communities' (ibid). The concept of a 'sustainability fix', notably, 'does not deny progress on ecological issues, but draws attention to the selective incorporation of environmental goals in the 
greening of urban governance ... [and] to the particular dilemmas urban regimes in different cities face in balancing economic, social and environmental demands' (While et al. 2004, p.551)

In step with While et al.'s (2004) concept of an urban 'sustainability fix', recent scholarship has begun to explore the selective incorporation of sustainability objectives into urban intensification and revitalization polices as part of 'smart growth' and other regional growth management strategies in cities across Europe and North America (Burton 2003; Bunce 2004, 2009; Gearin 2004; Bromley et al. 2005; Dixon and Dupuis 2005; Larsen 2005; Raco 2005; Lehrer and Wieditz 2009). Research on the emergence of 'smart growth' planning suggests that policies of urban intensification reflect a highly popularized urban environmental strategy that, while critical of growth, seeks to safeguard long-term growth in the wake of dramatic neoliberal urban restructuring and mounting public pressure to protect regional environments from low density suburban expansion, or 'sprawl'. As a policy discourse, smart growth supports a shift towards new high-density, mixed use urban development in a city's existing built landscape, namely its city centre, and is widely accepted in urban policy and planning communities as a 'sustainable' alternative to sprawl. Although many of the claims in support of urban intensification as a more environmentally sensitive and sustainable approach to urban planning and development remain largely unsubstantiated, the intensification of residential and commercial development in city centres has been associated with reduced development pressures in rural areas; the preservation of agricultural land to support local/urban food production; reduced traveling times to jobs, urban services, entertainment and shopping; reduced automobile dependency, lower greenhouse gas emissions, and better urban air quality; as well as improved health outcomes to name but a few (Neuman 2005). At the same time, in many advanced capitalist cities, municipal officials, planners and private sector real estate developers 
are also triumphant about the potential for urban intensification to promote the physical and economic revitalization of city centres by attracting mobile investment capital and middle class and more affluent residents back to the city. Although the discourse, debate and implementation of smart-growth inspired urban intensification policy is place-specific, conditioned by the multiscalar institutional contexts, regulatory frameworks and political realities in which they are situated, support for high density mixed use development has become a major urban environmental policy and planning objective in the United Kingdom, the United States, Canada, Australia and New Zealand and the subject of a growing body of critical urban scholarship. After more than a decade of policy experimentation in different urban and national contexts this work has begun to raise serious questions concerning the neoliberalization of urban intensification policy and development practices and its implications for and social (in)equality in the $21^{\text {st }}$ century 'sustainable city'.

Of particular relevance to my own examination of smart growth urban intensification in the City of Ottawa, Canada, is the emerging literature that argues that new build residential intensification and city centre revitalization strategies constitute examples of contemporary policy-led gentrification (Smith 2002; Lees 2003, 2008; Davidson and Lees 2005; Bromley et al. 2005; Bunce 2009; Lehrer and Wieditz 2009). Policy support for new medium and high-rise condominium development on vacated industrial and commercial sites, derelict waterfronts, and in under-populated or 'run-down' urban neighbourhoods, it is argued, has become an explicit strategy through which local governments seek to promote the physical and economic revitalization of inner city landscapes as part of a shift towards more entrepreneurial and competitive styles of urban governance. However, unlike gentrification practices of the $1980 \mathrm{~s}$ and 1990 s, recent gentrification scholarship draws critical attention to the selective incorporation 
of sustainability objectives into public sector urban intensification and revitalization policies and the role of private sector real estate developers in the implementation of such policies in different urban and regional contexts, highlighting the degree to which intensification strategies, and the discourses of 'sustainability' on which they are grounded, are closely aligned with, and made to serve, market-oriented urban development practices and the political-economic priorities of neoliberal urban governance regimes (Bromley et al. 2005; Raco 2005; Bunce 2009). Despite policy rhetoric that urban intensification and revitalization programs contribute to the production of more diverse housing types and tenures and, therefore, more social inclusive neighbourhoods, this growing body of literature suggests that the regeneration of city centre environments through market-driven high density urban development results in gentrification and the direct or indirect displacement of low income residents from 'revitalized' neighbourhoods (Davidson and Lees 2005; Bromley et al. 2005; Lehrer and Wieditz 2009). Largely stripped of its redistributive content and directed instead towards the sole pursuit of 'sustaining' urban growth and economic competitiveness, this literature is persuasive in arguing that discourses of 'urban sustainability', on which urban intensification and revitalization policies are increasingly based, appear more a political tactic on the part of local governments (in concert with private real estate developers) to silence opposition to new high density development and the inevitable social dislocations wrought be gentrification than a meaningful effort to craft more ecologically sustainable and socially equitable urban landscapes (Smith 2002; Lees 2008; Dixon and Dupuis 2003; Gilbert 2004; Bunce 2004, 2009; McCann 2007). 


\section{Conclusion}

This chapter explores several bodies of urban literature that have informed the research and analysis on which this dissertation is based. My doctoral research seeks to contribute to, and begin to tie together, recent scholarship in urban political ecology, theorizing of the urbanization of neoliberalism, and critical studies of gentrification. In bringing these different bodies of scholarship into more productive conversation, the goal of this research is to offer a thoughtful examination of the evolution of 'smart growth' municipal policy and planning in the City of Ottawa in a period of intense urban neoliberalization and the effects of municipally-supported, private sector-led high density development practices on access to affordable housing, particularly among low income populations, in neighbourhoods undergoing significant intensification and revitalization in Ottawa's urban core. 


\section{Chapter Three}

\section{Research methodology}

This chapter outlines the methodology developed and used to conduct the research that informs this dissertation. The chapter begins with a brief overview of the study's research objectives, followed by a discussion of the theoretical grounding supporting the use of a qualitative research methodology. The remainder of the chapter elaborates the specific methods used in this research project. Given the strong policy focus of the research, documentary analysis constitutes the core of the research methodology; however, semi-structured interviews and participant observation proved critically important methods both to triangulate and reinforce data collected through the review and analysis of policy texts and other documentary materials but also to explore ideas, issues and themes that could not be gleaned through documentary analysis alone.

\section{Research objectives}

The broad question driving this doctoral research concerns how highly popularized discourses of 'sustainability' are being actively, and selectively, incorporated into urban policy and planning regimes and local development practices in an era of intense urban neoliberalization. Given insights from recent urban scholarship that insist on a view of neoliberalization as a socially produced and historically and geographically specific process embedded in, and necessarily conditioned by, existing institutional frameworks, policy environments, regulatory practices and on-going political struggles at different scales (Brenner and Theodore 2002; Peck and Tickell 2002), this research was undertaken and is presented as an examination of 'actually existing' neoliberalization. Using the City of Ottawa as a case study, this research explores the place- 
specific ways that entrepreneurial and competitive styles of urban governance appear to increasingly rely on, in While et al.'s (2004, p.551) words, 'the active remaking of urban environments and ecologies' in different urban contexts. Specifically, the research uses the City of Ottawa's 2003 Official Plan as a pivot to explore the environmental politics of 'urban sprawl' and the ways in which discourses of 'urban sustainability' and 'livability' have been strategically incorporated into the City's of Ottawa new 'smart growth' planning framework and urban intensification policies, and used to legitimate public policy support for new market-oriented, high density urban development practices in the Ottawa's urban core.

Although the City of Ottawa serves as a case study grounding this research in 'place', questions of scale bear heavily on any analysis of municipal policy and planning in the Canadian context. Municipal governance, policy, and planning in Canada, as elsewhere, are shaped by relations and processes at other spatial scales. Municipal governments across Canada, for example, bear the scars of more than two decades of political economic restructuring by federal and provincial levels of government that have molded (and continue to shape) the contours of urban policy and planning regimes in profound ways. More specifically, municipalities fall under the legal jurisdiction of Canada's provinces and territories. In Ontario, urban and regional planning are required to conform to regulations and policies outlined in the Province of Ontario's Planning and Municipal Acts. Policy change in Ontario, including reforms to Ontario planning system, therefore, create new opportunities but also variously constrain municipalities in their official planning processes. Given this, this research has sought to explore and develop a better understanding of the 'contextual embeddedness' (Brenner and Theodore 2002, p.4) of municipal policy and planning in the City of Ottawa within in broader restructuring and reform processes at other spatial scales. 
At the same time, the City of Ottawa's current 'smart growth' planning framework and urban intensification policies promoting new high density urban development in the City's existing built landscape raise questions about how new high density urban development is transforming urban neighbourhoods undergoing intensification in ways that matter to local residents. In order to connect the City of Ottawa's policy of urban intensification to everyday development practices at the neighbourhood scale, a supporting objective of this research has been to examine the kinds of high density urban development approved by the City of Ottawa since the Official Plan's adoption and to explore public contestation of City-supported, private sector development practices in neighbourhoods undergoing significant intensifiation.

Temporally, the research concentrates on urban policy transformations since the provincially mandated amalgamation of the twelve lower tier municipalities of the former Regional Municipality of Ottawa-Carleton into one governance structure, the new City of Ottawa, in 2001. Although the research centres on the development and implementation of the City of Ottawa's Official Plan since its adoption in 2003, it also takes a historical perspective by situating the development of Ottawa's Official Plan and its new 'smart growth' policy regime in the context of broader political economic restructuring and planning reform experiments in Ontario since the early 1990 s.

\section{Towards a qualitative research methodology: theoretical insights}

Choosing and elaborating a research methodology can be challenging, since the choice of methodology is both an analytical and political one (Dwyer and Limb 2001, p.7). Though qualitative methodologies in human geography (and other disciplines) span a wide range of empirical work and philosophical underpinnings, as well as a variety of research techniques, they 
share an interest in and commitment to an intersubjective understanding of knowledge, in-depth approaches to research, a focus on power relations, and contextual, interpretive, subjective understandings of reality (Dwyer and Limb 2001, p.6). Critical qualitative methodologies differ from more quantitative ones in a number of ways, the most salient of which is that qualitative methodologies often (though by no means exclusively) stem from an ontological position that 'the world is not real in a fixed, stable or predictable way; that it is not entirely accessible; and that it does not appear empirically the same to everyone, no matter how carefully we look' (Smith 2001, p.25). In this respect, qualitative methodologies reflect a specific approach to what constitutes the production of knowledge.

Critical qualitative methodologies unsettle scientific understandings of objectivity, science's faith in the possibility of unmediated, value-free, dispassionate research and knowledge. As Haraway (1988) argues, objectivity is inevitably a language of power; it is a language of those who seem to stand apart from and outside of the materiality of knowledgeproduction. For Haraway, objectivity figured as disembodiment is a 'god-trick' that masks the ways in which our knowledge production practices are always socially and historically 'situated' and saturated with relations of power. In place of a pre-existing world that can be objectively known and measured, qualitative methodologies are grounded in an ontology in which the world is understood to be socially produced, an unstable 'assemblage of competing social constructions, representations and performances' (Smith 2001, 25). The notion of assemblages has become increasingly attractive to critical geographers because 'it captures the materiality of the world and its contingency', it points to the 'always becoming' nature of the world (Braun 2002, p.p.265). This is not to suggest that there are no permanences - 'landscapes change slowly, identities sediment and harden, and institutions become seemingly intractable' (ibid, p.266). 
Rather, it is to argue that things become fixed in only partial and provisional ways. That particular ideas or representations of the world, and not others, take hold and are established as 'truth' reflects the subtle, often unacknowledged, operation of power. As Smith (2001, p.25) argues, 'the ideas that stick and the practices that work are not fixed essential features of the landscape of a "real world". Rather they testify to the power relations, struggles and negotiations that allow particular versions and visions of the world to be realized in particular places and at particular times'. Importantly, particular regimes of truth, however permanent they may seem, are always unstable and never totalizing, they are always in the process of being contested, renegotiated and reworked.

Understanding all knowledge to be socially produced, qualitative methodologies do not seek to discover 'truths'. Instead, they are used to explore the multiplicity of meanings, representations, and practices, constituted in different political-economic, socio-cultural contexts, at different geographical scales, that go into building different accounts or experiences of the world. Without discrediting dominant institutions and knowledges, qualitative methodologies are grounded in an epistemology that does not privilege any single way of knowing. Instead, they acknowledge and attend to issues of social difference and the many different ways people differentiated along gender, ethnicity, race, income, age and other lines - know and experience the world around them. While qualitative methodologies can and often are used to explore the production of meanings in and through dominant institutional relations and processes - such as those of science, the market and the state - they can also be used to examine the explanations, meanings and experiences of the everyday. Qualitative methodologies offer ways to explore and understand lived experiences, to reflect on and interpret meanings in people's everyday lived worlds. In this respect, choosing qualitative methodologies is not simply an analytical choice but 
also a political one in the sense that by focusing on the explanations, meanings and experiences of the everyday "we are placing non-dominant knowledges at the centre of the geographical research agenda" (Dwyer and Limb 2001, 7). In this respect, qualitative methodologies create opportunities for previously marginalized, neglected voices to be acknowledged and integrated into urban geographical research in a way that, potentially, contributes to positive social change.

\section{Qualitative research methods in the study}

The research for this dissertation was undertaken over a two-year period, between 2008 and 2010. Grounded in a qualitative research methodology, the project drew extensively on a discursive analysis of policy texts and other documentary records, semi-structured interviews with key informants, and participant observation methods. Each method will be elaborated in turn below.

Documentary review and analysis: policy texts and other documentary materials

Given the policy focus of this doctoral research, the centerpiece of the research methodology involved the collection and analysis of policy texts and other documentary records produced by the City of Ottawa, the Province of Ontario and the Canadian federal government. The analysis of official policy texts was central to the research methodology as a means to examine the 'official line' or dominant policy narrative produced by different levels of government on an array of public policy issues germane to this research.

Drawing on the poststructuralist method of discourse analysis, policy texts (indeed all texts and forms of language) constitute a form of social practice through which meanings are created and reproduced. Unlike other research methodologies based on 'realist' epistemologies, 
'[d]iscourse analysis involves a perspective on language which sees this not as reflecting reality in a transparent or straightforward way, but as constructing and organizing that social reality for us' (Tonkiss 1998 cited in Hoggart et al. 2002, p.163). Although the analysis of discourse is more a 'craft skill' (Hoggart et al. 2002, p.165) than a distinct research method, a discursive analysis of policy texts and other documentary materials, focuses of the use of language, particular lines of thought, and strategies of argument. This method is particularly attentive to the social production of meanings, the inherently political nature of policy texts (and all forms of language), and the ways in which particular (policy) discourses go on inform and legitimate particular forms of intervention - in this case, policy intervention.

At the municipal level, documentary collection concentrated primarily, though not exclusively, on policy documents produced since amalgamation in 2001. The City of Ottawa's 2003 Official Plan and its supporting plans, and a vast array of policy documents, annual planning and development reports, pamphlets and other promotional and 'educational' materials proved critical documentary sources in elaborating how discourses of 'sustainability' have been incorporated into the City of Ottawa's new 'smart growth' planning framework and intensification policies guiding the implementation of new high density urban development practices in the city's built environment. The documentary research also included an analysis of minutes from Ottawa City Council meetings and from meetings of the City's Planning and Environment Committee (PEC), with the responsibility to review and make decisions on the merits of development applications, as well as debate and make recommendations to City Council on matters of policy with an urban and/or environmental focus.

To situate the City of Ottawa's new sustainability agenda, the Official Plan's smart growth planning framework, and its intensification policies in the context of on-going political- 
economic restructuring and policy change processes at other levels of government, documentary research also incorporated an analysis of federal and provincial policy texts and transcripts of parliamentary debates concerning recent political economic and policy transformations that have actively shaped municipal policy and planning since the early 1990s. These included, for example, a review and analysis of documents elaborating the Canadian government's new 'urban agenda' introduced by the Liberal Chrétien government and expanded under Prime Minister Paul Martin's 'New Deal for Canadian Cities' since the year 2000. Government of Ontario policy documents dealing with provincial planning reform from between 1990 and 2005 and policy texts and transcripts of parliamentary debates surrounding provincial-municipal restructuring initiatives introduced by the Ontario Harris-Eves government beginning in the mid-1990s, were particularly significant documentary sources. Published and unpublished reports, newsletters and pamphlets produced by non-governmental environmental organizations, affordable housing research and advocacy organizations, and anti-poverty coalitions active in provincial level politics were also incorporated into the research to explore public contestation of provincial planning reform proposals and provincial-municipal restructuring processes led by the Province of Ontario over the last two decades.

While analysis of policy documents and other government texts enables the researcher to explore the construction of official (or otherwise dominant) discourses that inform the development and implementation of government policy at different scales, it captures only the 'official story' and often only at a very general level of detail, requiring the use of complementary methods to explore the inherently unstable and contested nature of all government discourse and the policies, programs and development agendas they inform. The review and analysis of transcripts from provincial parliamentary proceedings and minutes from 
Ottawa City Council and PEC meetings, for example, provided an opportunity to explore (often heated) political debate on particular policy proposals and the consequences of recent policy change. Analysis of political debate helps to unsettle dominant policy discourses, by exposing its many fault lines, and making visible alternative ways of defining or prioritizing policy issues.

\section{Semi-structured interviews with key informants}

To explore and develop a more in-depth and contextualized understanding of recent and ongoing urban policy and planning reform in the City of Ottawa, the research methodology also involved semi-structured interviews with key informants in Ottawa. A total of 49 interviews were conducted over a two-year time frame with individuals from municipal government, nongovernmental and not-for-profit organizations, local community and neighborhood-based associations and Ottawa's real estate industry (Appendix 1). At the beginning of each interview, prospective interviewees were given a letter of informed consent that introduced myself, explained my institutional affiliation as a doctoral student in the Department of Geography and Environmental Studies at Carleton University, and described the nature and focus of the research project and their rights as a participant in this research. Concerning confidentiality, participants were assured that their individual responses would not be attributed to them in the written dissertation or any other form of documentation produced by this research (e.g. any other form of reporting). Most interviews were approximately 1.5 hours in duration, although in particular cases a second interview was organized to follow-up on, and explore in greater depth, particular issues and themes. All interviews were 'taped' with a digital voice recorder to limit disruptive note taking and permit fluid, attentive conversation with interview participants. The research relied on 'selective transcription' as not all interviews (or segments of interviews) yielded 
insights of particular significance. For the purposes of discursive analysis, the benefit of transcription is that is enables the researcher to return to and analyze the precise language particular words, concepts, and turns of phrase - used by interview participants to construct and convey their ideas and lines of argument.

In Ottawa's municipal government, interviews were requested from all elected city councilors representing Ottawa's twenty-two wards. Letters were sent, by electronic mail, to all city councilors to introduce myself as a doctoral student in the Department of Geography and Environmental Studies at Carleton University, explain the nature of the research project, and request their participation in an interview as part of the research. Approximately half of the seated councilors agreed to participate in an interview. With a few notable exceptions, it was primarily councilors from urban wards, where the City of Ottawa's residential intensification policies and development practices are most concentrated, who granted an interview. Interviews with city councilors sought to examine how the City's intensification policies were being implemented 'on the ground' in their respective wards, including neighbourhood contestation of new high-density residential and mixed-use developments approved as part of the City's intensification mandate.

Interviews with councilors also constituted an opportunity to examine the politics of 'smart growth' and 'intensification' on City Council. Specifically, interviews sought to expose and explore the deeply contested nature of the City's intensification policies and development practices among elected officials on Council. Following amalgamation, the majority of the twenty-two seats on Ottawa's City Council represent suburban and rural wards. Councillors representing urban wards (wards located inside Ottawa's greenbelt), therefore, constitute a minority on Council. Under the Official Plan and the City's intensification policies, however, the 
lion's share of new high-density urban development is targeted to neighbourhoods inside Ottawa's greenbelt making policy and development decisions (dominated by rural and suburban councilors) on Council deeply divisive. In this respect, interviews with councilors served to highlight some of the governance dilemmas facing the new City of Ottawa since amalgamation that have dramatically shaped the politics of intensification across the city region.

Interviews were also requested and granted with several city planners in the City of Ottawa's Planning and Growth Management Department and staff from the City's Housing Branch. Although in some cases, as above, interviews were requested by electronic mail, I had an opportunity to meet most of the planners interviewed as part of this research project at Citysponsored events where I introduced myself and my research project and requested an interview. Interviews with planners and other city staff were intended to explore, elaborate and (politely) challenge the City's official policy narrative that 'smart growth' and urban intensification constitute a 'sustainable' and socially equitable alternative to low-density urban sprawl in the Ottawa region. In particular, interviews with planners and staff from the City's Housing Branch provided an opportunity to raise difficult, and inherently political, questions about the potential for new high-density residential development to reduce housing affordability and intensify gentrification practices in Ottawa's urban core.

Interviews with individuals outside of municipal government were organized as a means to examine public reaction to, and contestation of, the City's smart growth planning framework and intensification policies at an urban and neighbourhood scale. Representatives from Ottawabased environmental organizations active in municipal debates surrounding the City's smart growth intensification strategy were interviewed to discuss the City's intensification mandate in relation to pressing environmental and public health concerns associated with urban sprawl, 
public anxieties about the implications of intensification for urban quality of life, and the fierce public contestation surrounding the City's proposal to expand Ottawa's urban growth boundary during the 2009 Official Plan Review.

Interviews with not-for-profit affordable housing providers in Ottawa's downtown core were also organized to discuss recent provincial-municipal restructuring in Ontario, especially cuts in federal and provincial spending on social housing programs and the downloading of social housing responsibilities to the municipality, and the effects of these reforms on the provision of affordable housing in the City of Ottawa. These interviews also provided an opportunity to explore the perspectives of local affordable housing providers on the City's 'smart growth' planning agenda and its intensification policies supporting private sector-led, highdensity residential development in Ottawa's urban core. In particular, interviews sought to capture concerns that the City's intensification strategy was producing an escalation in downtown housing prices, creating incentives for the conversion of rental units to ownership housing, and resulting in an overall net loss in affordable housing and the potential direct or indirect displacement of low-income residents from downtown Ottawa. In these interviews, the intention was also to create a space for affordable housing providers to articulate alternative ways of thinking about 'sustainability' in relation to social equality and inclusion and, more broadly, urban quality of life.

Although the research project was ultimately focused at the policy level, it also sought to explore how municipal support for market-driven, high-density urban development was transforming Ottawa's urban neighbourhoods in ways that matter to local residents. Early on in the research process, observation of City Council and PEC meetings revealed the active role of neighbourhood-based community associations in the politics of intensification in Ottawa. 
Interviews were organized with community association representatives in urban neighbourhoods targeted for, or already undergoing, significant urban intensification. A contact list of Ottawa's community associations was obtained from the Federation of Citizen's Associations, an umbrella organization through which local community associations collectively organize and press their concerns at City Hall. Once again, letters were sent, by electronic mail, to community association representatives to introduce myself and explain the nature of the research project, and request their participation in an interview. Interviews were granted by twelve community associations representatives from different parts of Ottawa. Notably, all that granted interviews represented urban neighbourhoods where intensification has become a deeply politicized and contested issue, suggesting that community associations perceived this research project as an opportunity to critically discuss, and air grievances, about the City's intensification mandate and its implementation in Ottawa neighbourhoods.

Interviews with community association representatives were intended to explore community-based reaction to the City's 'smart growth' intensification strategy as it is conceptualized in the Official Plan and to discuss local resistance to new high-density development in their neighbourhoods. While the vast majority of interviews in the research project were situated at the offices of participants to minimize imposition on their time, interviews with community association representatives were undertaken in their neighbourhoods of residence. Most interviews included 'neighbourhood walks' with interview participants as a way to explore and discuss, in greater depth (and with visual referents), community reaction to new medium and high-rise residential developments (as well as so-called 'monster home' construction) and the specific ways in which intensification is transforming the built environment of local neighbourhoods in ways that matter to residents. 
The main limitation of interviews with community representatives related to the class constituency of the associations themselves. Though many are becoming increasingly gentrified, most community associations engaged in the research process represented mixed income neighbourhoods that, to varying degrees, were socially and culturally diverse. Through the research process, however, it was discovered that community association membership is dominated by highly educated, middle class and more affluent residents in most (if not all) of Ottawa's inner urban neighbourhoods. Consequently, the voices of residents living on low income and of diverse ethnicities and backgrounds were not adequately represented in the interview process. Without diminishing the valuable contributions of middle class community association representatives to the research process, the experiences and concerns of lower income residents regarding, for example, access to affordable housing vis-à-vis the City's residential intensification program constitutes a missed research opportunity.

Finally, to tease out further the complex and contested nature of the City of Ottawa's urban intensification strategy, and development politics in the city more broadly, I also approached real estate developers from across the city region to participate in an interview as part of study. Although I had anticipated that most would not grant an interview, the presidents of several private sector development firms agreed participate in an interview. The objective of these interviews was to examine the position of Ottawa real estate industry on the City's policy shift away from low-density suburban growth in favour of new high-density residential (and mixed use) development in Ottawa existing built fabric. 


\section{Participant Observation}

To develop a better understanding of issues affecting the City's most vulnerable residents, particularly those living on low income and newcomers to Canada, I became actively involved, as a participant observer, in People for a Better Ottawa (PBO). At the time of my research, PBO was a broad-based coalition of individuals, representatives of Ottawa's Community Health and Resource Centres (servicing the city's low income and minority populations at the community level), local unions and community-based environmental and social advocacy groups concerned about Ottawa's declining quality of life in the wake of more than a decade of provincial and municipal level restructuring. Among its many political campaigns, PBO was active in the City of Ottawa's annual budget deliberation process, during which it pressed for renewed municipal funding to the City's social services and infrastructure programs that serve Ottawa's most vulnerable populations and the necessity that the Province of Ontario 'upload' previously provincial financial responsibilities back to the provincial government. My participation in PBO meetings, community events and political activism provided considerable insight into issues of inequality in access to social services and community infrastructure (such as affordable housing) beyond that which could be gleaned solely from municipal reports and one-time interviews.

My work with PBO, over a period of a year and a half, also created an opportunity for a more meaningful, 'two-way' exchange of ideas. In the past, PBO had not work explicitly on issues related to urban planning and development as these processes were regarded as only loosely connected to matters of social equality in the city. However, through my own research and political engagement with the coalition I was able to share insights from my research with coalition partners and begin a conversation about the dynamic relationship between public sector support for market-oriented development practices and housing affordability trends in Ottawa's 
housing system. Moreover, this research brought PBO's attention to existing planning tools, such as Section 37 agreements (see Chapter 7), through which city officials and planners, under Ontario's Planning Act, can negotiate the creation of affordable housing units (or other 'community benefits') in exchange for increases in building height or density, as part of new intensification projects (a tool that the City of Ottawa has, to date, not utilized as part of its development applications process). Although the activities of $\mathrm{PBO}$ are currently waning, as new local coalitions establish themselves, the relationship between my research and PBO's political advocacy appears to have been a positive and productive one.

In addition to research and advocacy efforts with $\mathrm{PBO}$, the research project involved extensive participant observation during public events and consultation processes as part of City of Ottawa's 2009 Official Plan Review and in a variety of citywide public meetings, communitybased events and public protests dealing with issues germane to research. The objective of participant observation in City-organized and community-based public meetings and events was, again, to capture and examine the diversity of experiences, opinions, and lines of argument brought to bear in debates about the City's smart growth agenda, intensification policies and development practices.

\section{Use of quantitative, statistical data}

Although my research relied primarily on qualitative research methodologies, quantitative, statistical data, mostly from published secondary sources, were collected to explore particular trends. Data on cuts in federal and provincial spending on affordable housing and social assistance over the last two decades, for example, were used to clarify and reinforce the dramatic implications of neoliberal restructuring and reform processes on the everyday lives of Ontario's 
low income and minority populations. In the City of Ottawa, quantitative data on ownership and rental housing market trends and housing affordability in Ottawa's urban core were, likewise, used to support and strengthen findings obtained from qualitative research methods.

\section{Conclusion}

Building on insights from recent urban scholarship this research was undertaken and is presented as an examination of 'actually existing' neoliberalization, using the City of Ottawa. This chapter provided an overview of the methodology used to undertake this research project. With a particular interest in the production of discourses of 'sustainability' in policy and planning arenas at both the municipal and provincial levels and the consequences of, and political contestation surrounding, new high density residential development in Ottawa's inner urban neighborhoods, this study relied on a qualitative research methodology that included extensive documentary research and analysis, semi-structured interviews with key informants representing different stakeholder communities in Ottawa, as well as participant observation in a variety of Citysponsored and community-based public meeting and events. Taken together, and supported by quantitative, statistical data where appropriate, this methodology enabled a thoughtful exploration of the research questions guiding this study. 


\section{Chapter Four}

\section{The neoliberalization of Ontario planning in a period of provincial-municipal restructuring, 1990-2001}

\section{Introduction}

Since the end of the Second World War, large and rapidly growing municipalities in Ontario, as elsewhere in North America, have pursued an aggressive growth strategy premised on the decentralization of new residential and commercial development outward from their city centres. The arrival of modernist planning brought with it the 'dream of a better city', a dream inspired by the Garden City and City Beautiful movements of Ebenezer Howard and Frank Lloyd Wright which, decades earlier, promised a departure, both material and symbolic, from the old industrial city (Sewell 1993). Early modernist plans in Ontario, like the 1950 Gréber Plan for Ottawa's National Capital Region, viewed low density suburban residential development, separated from industrial and commercial land uses, and surrounded by ample, 'natural' greenspaces, as key features of a modern and more 'livable' city - 'the good life'. The ascendance of the private automobile, Canadian home mortgage programs, and massive public investment in new roads and highways and the extension of water and sewer infrastructure to new suburban communities made the dream of a home in the suburbs possible.

By the early 1970s, however, the consequences of large-scale suburbanization were fast becoming a matter of intense public concern in many Ontario municipalities. The fabric of cities was changing - people lived farther apart from their neighbours; houses, shops and workplaces, that once co-existed were now separated; trips once made on foot or by bus or streetcar were increasingly made by private automobile (Gurin, 2003, p.3). Low-density suburban expansion had begun consuming land, often productive agricultural land and other non-urban environments, 
on the periphery of cities at a pace and scale that far exceeded that of older, denser pre-war urban neighbourhoods. Inner cities were in decline and disrepair as municipalities directed ever-greater proportions of public investment to extend infrastructure and services to new suburban growth areas (Sewell 2009). Municipal governments had also begun to feel the economic pinch of sprawl as property taxes and development charges generated by new suburban development rarely, if ever, covered the costs of new roads, water and sewer infrastructure and public services to these areas. In rapidly growing municipalities like Toronto and Ottawa, where the socioecological implications of low-density suburban expansion were most acute, the 1970s and 1980s marked the beginning of shift in urban growth politics as environmental activists, in particular, began to question the logics of 'sprawl' and express support for a return to more compact, mixed use and transit-oriented urban development.

The 'anti-sprawl' environmental movement in Ontario gained considerable prominence by the late 1980 s, coinciding with the Bruntdland Commission's report, Our Common Future (WCED 1987), which brought about a paradigm shift of sorts in urban policy regimes across Canada, as elsewhere. By the early 1990s, Ontario's planning system had begun to strategically deploy the language of 'sustainable development' as a 'discourse on growth ... reborn as a discourse that is naturally critical of growth in order for local [and provincial] politicians and planners to be able to sustain it' (Keil and Ronnenberger 1994, cited in Keil and Graham 1998, p.107). The Commission on Planning and Development Reform (CPDR), appointed by the NDP government in Ontario in 1991, initiated the first in a series of planning reform experiments, premised on a commitment to curb sprawl through policy supportive of compact 'sustainable' urban development patterns in the Ontario municipalities. This shift in urban growth politics drew explicitly on the rhetoric of sustainable development discourses of the time, wherein 
'sustainability' is satisfied by the requirement that planning address the three objectives of economic growth (and efficiency), environmental protection and social justice - what is, in today's vernacular, referred to as 'the triple bottom line' (Braissoulis 1999). Compact, mixed use development, which directed new residential and commercial development to already built-up areas of a city, rather than to so-called 'greenfields' (land not already developed for urban uses), it was argued, promised the protection of agricultural land and significant ecological systems from unnecessary (or, at least, premature) urban expansion; the creation of more vibrant and inclusive urban neighbourhoods (that were more pedestrian- and transit-oriented and offered more diverse and affordable housing options than traditional suburban development), while still, and quite crucially, satisfying the imperatives of urban growth and economic development. With a few notable exceptions in the CPDR's 'new planning' reform agenda, only the geographies of urban growth and development appeared to have changed.

The politics of urban growth, however, only intensified in Ontario following the election of a Progressive Conservative government, under Premier Mike Harris, in 1995, which ushered in an era of intense 'roll-back neoliberalism' (Peck and Tickell 2002) in the province. Between 1995 and 2000, the Harris government, as part of its 'Common-Sense Revolution', imposed a series of dramatic cuts in provincial spending on municipal infrastructure and services and later downloaded these provincial responsibilities to local governments. During the same period, it repealed the planning reforms that flowed from the CPDR, loosening planning restrictions in support of an aggressive market-driven (sub)urban growth strategy. Yet, in the aftermath of this first wave of neoliberalization in Ontario, in what seemed a remarkable turnabout, the Harris government announced, in 2001, its new 'Made-in-Ontario smart growth strategy' to curb regional sprawl and promote more 'sustainable' urban growth and development in Ontario cities. 
Focusing on provincial planning reform experiments in the Province of Ontario from 1991 to 2001 , the aim of this chapter is to explore the broad context of political economic restructuring and governance change that gave rise to a new 'smart growth' inspired planning regime in Ontario (the focus of Chapter 5). In step with recent critical scholarship in the field of urban political ecology (While et al. 2004; Raco 2005; Heynen et. al. 2007; Keil and Graham 1998; Keil and Boudreau 2006; Keil 2007), this chapter (and the next) develop the argument that environmental governance and planning policy change in Ontario, in recent years, appears to constitute a defining feature of a new wave of neoliberalization across the province. Beginning with the CPDR reforms of the early 1990s, and later taken up by the Harris-Eves government's 'Made-in-Ontario' smart growth planning reform experiment beginning in 2001, successive governments have sought to manage the inherent dilemmas, contradictions and consequences of capitalist urban development while, simultaneously, addressing the demands of a growing antisprawl environmental movement in Ontario by (selectively and strategically) incorporating ideas of 'nature', 'environment' and 'sustainability' into provincial land-use planning and development policies. The recent history of planning reform experimentation in Ontario has not, however, sought to mount a serious challenge to neoliberal capitalist urbanization, but rather, appears geared toward securing its long-term future by making (or appearing to make) 'urbanization work in [and through] nature' (Keil and Graham 1998, p.107).

\section{'New Planning for Ontario': The Commission on Planning and Development Reform}

In Canada, municipalities are not recognized by the Constitution as a distinct and separate level of government; rather, they are designated as 'creatures of the provinces'. The size, structure, powers and responsibilities of municipalities are legislatively granted by the provinces in the 
form of a Municipal Act and/or Planning Act, and can be (and frequently are) restructured at provincial discretion (Fischler et al. 2004; Pond 2009). Municipal planning in Ontario is governed by the province's land use planning system. Ontario's Planning Act of 1946 establishes the authority, policies and procedures governing land use in the province that municipal governments and planning authorities are required to follow in all land use planning and decision-making.

The provincial government in Ontario, despite having jurisdiction over municipal affairs, assumed a rather limited role in planning before the $1980 \mathrm{~s}$. Although the Ontario government approved massive infrastructure investments in the province's highway system as well as in large scale water and sewer projects in support of suburban expansion, particularly in Southern Ontario, from the 1950s onward (Sewell 2009), it had done very little to establish clear and enforceable policy to guide planning and development in Ontario municipalities. By late 1980s, however, there had been a dramatic escalation in the politics of (sub)urban growth in Ontario, so much so that "the integrity of the entire planning system was being called into question" (CPDR 1993, p.1). Most immediate and pressing perhaps, were revelations concerning the influence of some developers over planning decisions in several municipalities in southern Ontario. On June 6,1991 , the provincial government, led by then-Premier Bob Rae, appointed a royal commission to investigate what it assumed to be corruption in Southern Ontario's York Region (Sewell 2009, p. 169). The Commission on Planning and Development Reform (CPDR) in Ontario, as it was known formally, was chaired by long time urban activist and former mayor of Toronto, John Sewell. George Penfold, professor of planning at the University of Guelph, and Toby Vigod, an environmental lawyer and former executive director of the Canadian Environmental Law Association (CELA), were appointed commissioners. Although the original mandate of the 
CPDR was narrowly concerned with the charges of corruption, the Commission Chair, who for years had openly criticized the mass suburbanization of the Greater Toronto region, argued that the Commission's mandate be transformed 'from an investigation into wrong-doing to a review of planning legislation in order to address the more general question of suburban sprawl and the related impacts of low-density development' in Ontario (Sewell 2009, p. 169; Sewell; Personal Interview, July 28, 2009).

By the beginning of the 1990 s, the proliferation of low-density suburbanization over the preceding decades, not only in the Ottawa region but also across much of Southern Ontario, had intensified concerns about sprawl province-wide (Sewell 2009). With more than half of Canada's Class 1 agricultural land found in Ontario, the rapid loss of productive farmland to suburban expansion was becoming a pressing matter, particularly in Southern Ontario. At the time of the CPDR's appointment, nine percent of the province's best agricultural land had been converted to urban land; in 2001, this figure had risen to 11 percent and continues to climb (Statistics Canada 2005, p.7-8). Once consumed, this land is, for all intents and purposes, permanently lost from agriculture. Likewise, the CPDR drew attention to the consequences of poor land use planning for the integrity and functioning of ecological systems, citing the loss of nearly 90 percent of wetlands, along with important flora and fauna, to suburbanization in some Southern Ontario counties (CPDR 1993, p.17). The pollution of ground and surface water, the depletion of groundwater reserves, the loss of wildlife habitat and increasing carbon dioxide emissions that had, for decades, proliferated as a result of largely unregulated low density growth in and around Ontario's major urban centres were also identified as salient concerns. The Commission was acutely aware of mounting public frustration over the apparent failure of the Ontario government to protect the environment from large-scale suburbanization, spurring a new wave of 'anti- 
sprawl' activism across the province by the early 1990s - the coalition to 'Save the Oak Ridges Moraine' (STORM) being a notable example. In short, the ecological 'externalities' of more than three decades of capitalist (sub)urbanization had, by the early 1990s, become a matter of intense public policy concern.

During the same period, the question of whether municipalities could afford to extend infrastructure and deliver services to low-density suburbs at ever-greater distances from their city centres was also becoming a matter of growing debate. Although concern about the long-term financial implications of suburbanization were not new to Ottawa and other large municipalities in the province, the global economic recession of the early 1980s, and the onslaught of federallevel political-economic restructuring and retrenchment that followed in its wake, reinvigorated debates about the 'costs of sprawl'.

Historically, Canadian cities had benefited from comprehensive federal and provincial support for municipal infrastructure and services. Beginning in the mid-1980s, however, the rolling-back of Canada's welfare state and the dismantling of federal support for municipal activities by the Mulroney government had shifted enormous financial burdens on to municipalities in Ontario, and across Canada. Between 1984 and 1993, for example, the federal government cut almost $\$ 2$ billion from housing programs, and by 1993 had canceled funding for the construction of new affordable housing units (Shapcott 2006, p.6). The devolution of federal and later provincial responsibilities to municipalities without commensurate resources and revenue-generating authority to meet these new responsibilities - a shift that deepened throughout the 1990s - left municipalities in a situation of profound 'fiscal crisis' (FCM 2006a). The effects of first-wave federal restructuring on Ontario municipalities, in combination with 
heightened awareness of the negative environmental 'externalities' of unregulated suburban expansion in the province, set the tone and direction for the CPDR process.

The position of the CPDR was that urban sprawl in Ontario was, ultimately, the result of a weak and unenforceable provincial planning policy regime. Earlier reviews of Ontario's planning system in the 1970s had already identified the absence of legislation defining 'provincial interests' related to land-use planning as a significant obstacle to 'good planning' in the province. In 1977, the Ontario Planning Act Review Committee (PARC), for example, recommended amendments to Ontario's Planning Act to establish 'provincial interests' in land use planning that would be used to inform specific provincial land use policies, implemented 'by way of regulations or other statutory orders, formally adopted by the provincial Cabinet and having the force of law" (Penfold 1998, p.150). In other words, the review pointed to the need not only for sound planning policy but also, and just as importantly, planning policy that is formal and enforceable.

In 1983, the Ontario government amended the Planning Act to include, for the first time, defined provincial interests and procedures for the review and approval of policies by provincial Cabinet. Under the 1983 Planning Act, provincial policies were to be implemented through a requirement in the legislation that all municipal governments and other decision making authorities were to 'have regard to' provincial policies in their decisions. Under the 1983 Act, all official plans, amendments to plans, and any large-scale development plans (such as a plan of subdivision) required approval by Ontario's Minister of Municipal Affairs. Any conflict over the interpretation and implementation of policies could be resolved by way of appeal to the Ontario Municipal Board (OMB) (ibid, p.151). Between 1983 and 1992, however, the provincial government adopted only four policies pertaining to mineral aggregate resources, floodplain 
planning, land use planning for housing, and wetlands conservation. By and large, as Penfold argues, the process of developing provincial policy proved 'challenging and conflict-ridden', due in part to the active involvement of 'diverse interests' and the contentious nature of the issues (ibid). Ontario's Wetlands Policy, for example, took more than 10 years to move from concept to approval. From that point onward, many ministries sought to develop 'guidelines' as an alternative to formal policy, in part because they could be approved without public consultation, potentially avoiding the problems of conflict and time delay. However, as Penfold makes clear, the lack of public consultation in the preparation of provincial planning guidelines simply shifted the terrain of conflict to the municipal scale. In the absence of strong, enforceable provincial policy to guide local planning decisions, the review of official plans and development applications had become increasingly politically charged and time consuming processes with review timeframes of three to five years common for major plans and development applications, and an additional two years required if an approval was appealed to the OMB (ibid, p. 151-152). But also, and quite critically, in a policy vacuum such as this, suburban development in municipalities across Ontario had, for decades, been driven more by the profit motivations of land speculators and real estate developers and the desires of municipalities to expand their property tax base than by 'good planning'. The outcome has been the proliferation of largely unplanned, low-density suburbs - 'sprawl'.

Given this context, the CPDR's mandate was both substantive and procedural. It was appointed to 'recommend changes to the Planning Act and related policy that would restore confidence in the integrity of the planning process, protect public interests, better define roles and relationships, focus more closely on protecting the natural environment, and make the planning process more timely and efficient' (CPDR 1993, p.1). Unlike earlier reviews of 
Ontario's planning system (see Penfold 1998), the CPDR was lauded for its comparatively participatory and inclusive approach to planning reform. An explicit goal of the CPDR was to find 'common ground' among diverse stakeholders in Ontario's planning system, including 'planners, developers, citizen activists, environmentalists, farmers, municipal staff and politicians, provincial staff and politicians and others who work with the planning process' (CPDR 1993, p.5). The Commission was tasked with ensuring the 'widest possible public participation' and over a two year period organized more that forty public forums in different locations across the province while also convening meetings of fifteen different working groups, sponsoring thirty-eight less formal community meetings, and meeting regularly with many organizations closely involved in planning (ibid).

The Commission's final report, entitled New Planning for Ontario, released in June 1993, contained ninety-eight recommendations for planning reform in the province. In December 1993, the Ministry of Municipal Affairs released a draft Comprehensive Set of Policy Statements, based on the CPDR recommendations, which was approved by Cabinet in May 1994. In the same month, the Ontario legislature gave first reading to Bill 163, the Planning and Municipal Statute Law Amendment Act, which was later passed by the Ontario government in December 1994 and came into effect in March 1995.

For environmentalists in Ontario, the CPDR process and the reforms contained in Bill 163 were suggestive of a rather progressive moment in Ontario planning. Since Ontario's Planning Act, up to that point, had not sufficiently elaborated the very purpose of the planning, Bill 163 amended the Planning Act to make explicit that 'the purposes of the Act is to guide land use change in a manner that: fosters economic, environmental, cultural, physical, and social wellbeing; protects and conserves the natural environment and conserves and manages natural 
resources for the benefit of present and future generations; provides for planning processes that are fair, open, accessible, accountable, timely, and efficient; and, encourages cooperation and coordination among differing interests' (CPDR 1993, p.134).

To provide clarity and consistency in the definition of provincial interests the CPDR recommended that the Province adopt a comprehensive set of policy statements under. Section 3 of the Act, to be reviewed every five years. The policy statements, and their constituent policies, passed by the Ontario government covered a range of planning matters including: natural heritage and ecosystem protection and restoration, community development and infrastructure, housing, agricultural land, energy conservation, and non-renewable resources, as well as a policy statement pertaining to the implementation of policy under the Planning Act (ibid, p. 136-141). To ensure that new provincial planning policies were sufficiently enforceable, the CPDR also recommended that the former requirement that planning decisions 'have regard to' provincial policy be strengthened. The Commission called for:

The Planning Act to be amended to provide that in exercising any authority that affects any planning matter, the council of every municipality, every local board, or authority, every minister of the Crown and every ministry, board, commission or agency of the government, including the Ontario Municipal Board and Ontario Hydro, shall be consistent with policies adopted under the Act (CPDR 1993, p.135, emphasis in the original).

The intention of this legislative change was to strengthen the former requirement that municipalities and other planning authorities 'have regard' for provincial policies under the Planning Act. To ensure implementation the province retained the authority to approve county and regional plans, while second-tier governments were given authority to approve local plans, which also had to be consistent with provincial policies and upper-tier plans. 
Although the language of 'smart growth' would not enter provincial planning discourse and debate until the late 1990 s, efforts to define a 'new approach' to urban and regional planning premised on more compact, mixed use urban development patterns has its roots in the CPDR process. The Commission argued persuasively that the suburban growth regime in Ontario was proving 'unsustainable' both ecologically and fiscally, and proposed legislative changes to the Planning Act regulating where and how future urban development should (and should not) be permitted to occur. Alongside recommendations prohibiting development on prime agricultural land and in provincially significant ecosystems and requiring that environmental impact studies be undertaken before development is approved in other environmentally sensitive areas, the Commission proposed an approach to planning that would encourage more compact forms of urban growth and development. Specifically, the Commission recommended planning legislation that would direct growth, first and foremost, to existing built up areas to encourage the efficient use of land, infrastructure and public services. It stressed that extensions to built-up areas, not already served by public infrastructure, be permitted only under certain circumstances. In other words, municipal planners and developers would, for the first time, be required to 'make a case' for new development on so-called 'greenfield' lands (lands not yet built up for residential or commercial use) under provincial legislation. The Commission argued that new development should only be permitted under provincial policy if all of the following criteria were met: 1) new development areas are logical extensions of the existing built-up areas; 2) the long-term adequacy of private or public or communal systems of water supply and sewage treatment is demonstrated; 3) a strategy for the development, staging, and financing of any needed infrastructure and public service facilities for the extension is adopted; 4) the extension will have a compact form and densities and uses appropriate to the water and sewage systems proposed; 
and, 5) if the extension is to include quality agricultural land, it is demonstrated there is no reasonable alternative to accommodating the growth anticipated. Further to this, the Commission argued that future growth in rural areas, other than quality agricultural areas, be required to meet the same criteria while also ensuring that the character of rural communities is not compromised by new development (CPDR 1993; p.31-32).

Policies that encourage 'residential intensification' were to be a centerpiece of new planning legislation. The Commission recommended that all new urban development in Ontario's cities, whether in existing urban areas or as part of new suburban development, be required to occur at higher residential densities than in the past (measured in by the number of units per hectare of land) and be planned to include a mixture of land uses, not unlike those of traditional neighborhoods of the Ontario's older inner cities that offered residential, employment, retail and recreational opportunities in the same area. In the proposed policy statement on Community Development and Infrastructure, the Commission argued that compact, mixed use development would not only ensure the efficient use of infrastructure and conserve urban land, but would also encourage the kinds of urban development that better meets the everyday needs of residents. Planned right, and with the necessary investment in community infrastructure, compact development could be more socially inclusive and equitable, by creating opportunities for a greater diversity of housing types and tenures (including ownership and rental housing) at a neighborhood scale, ensuring a more equitable distribution of facilities and services available to residents with diverse needs, and enabling the everyday use public transit, cycling and walking as viable alternatives to the private automobile (ibid).

Of particular promise, the Commission's report drew attention to the potential for residential intensification to contribute to the provision of affordable housing in Ontario cities. 
Affordable housing, as a planning mandate, was addressed for the first time in the 1989 Land Use Planning for Housing policy. In this policy statement, Ontario's large and rapidly growing municipalities were directed for the first time to plan for a full range of housing types. This housing statement was prepared in response to the rapid growth in demand for housing, particularly in southern Ontario. At the time, the private development industry focused its energies and resources on the construction of higher priced single-detached dwellings and luxury condominiums, ignoring much needed smaller and more affordable housing (Blickstead and Shapcott 2010, p.3). Building on the 1989 housing policy statement, the CPDR proposed changes to the Planning Act requiring municipalities provide for the creation of housing that is 'accessible, adequate, and appropriate' to 'households diverse in ability, age and income' (CPDR 1993, p.32). It recommended that affordable housing requirements be increased from 25 to 30 percent (affordable to the $60^{\text {th }}$ percentile of household income distribution in the area), and that this target apply to new units created through residential intensification and redevelopment and to new suburban development on 'greenfield' lands. Further, the Commission argued that innovative development, small-scale intensification, and residential conversion be used to create opportunities for housing affordable to the $30^{\text {th }}$ percentile of household income distribution (ibid, p.33). These recommendations were adopted in the Rae government's new Provincial Policy Statement, passed by the Province of Ontario in February 1995.

Options for improving the affordability of housing, and increasing rental housing stock, through small scale residential intensification were also expanded under another piece of legislation introduced under Bill 20, The Residents Rights' Act, approved by the Rae government just months earlier, in December 1994. This legislation required that municipalities permit 
secondary rental units in existing houses (such as basement apartments), provided that building, fire and planning standards are met.

The CPDR planning reforms were noteworthy in part because they were first of its kind to challenge, in a comprehensive manner, the prevailing suburban growth regime in Ontario in an effort to bring then-emerging concerns about 'nature', 'environment' and 'sustainability' to traditional land-use planning. But also, and just as significant, the reforms were attentive to the progressive potential of land-use policies to foster more socially equitable and inclusive urban development patterns. Higher density, mixed use development, was not simply a means to ensure the conservation and efficient use of urban land, it also held the promise of improved housing affordability and choice and the creation of more walkable and transit-oriented neighbourhoods and, thus, more socially inclusive urban regions in Ontario.

However, the CPDR process and the planning reforms contained in Bill 163, though undeniably progressive, were by no means anti-growth. During the CPDR process, municipalities and the development industry argued that bureaucratic red tape and delays in the planning system were stifling urban development, a position supported by the Rae government. As the Honourable Ed Philip, then Minister of Municipal Affairs, explained: 'We cannot continue to support a costly and inefficient land use planning system. The impact of the delayed decisions costs millions of dollars in delayed economic activity and potential employment' (Legislative Assembly of Ontario, 1994). In response to these concerns, Bill 163 included administrative reforms intended to 'streamline' the planning and development process, by clarifying the roles and division of responsibilities between the province and municipalities and elaborating clear rules and procedures to guide and expedite urban development in the service of economic growth. With a view to making planning and development more efficient and timely, 
the reforms also expanded the power of the OMB to dismiss appeals without a hearing where concerns are deemed to be without merit, potentially undermining the capacity of communitybased and public interest groups to challenge development decisions before the board.

More broadly, the environmental and fiscal implications of continued low-density surburbanization for municipalities and the Province of Ontario did not, for the most part, generate serious questioning of the imperatives of 'growth' or bring about debate concerning potential alternatives to capitalist urbanization. Drawing explicitly from the discourse and politics of 'sustainable development' which had gained prominence just a few years earlier, the CPDR recommendations were founded on a commitment to 'balance environmental and economic considerations' in all land-use planning and development decisions and, in this respect, are entirely consistent with the contemporary 'win-win' politics of ecological modernization (Hajer 1995). Rather than mount an outright challenge to capitalist urbanization, at the heart of the CPDR planning reforms lay a firm commitment to 'getting growth right' through the (selective) incorporation of environmental goals into Ontario's land-use planning system. The CPDR actively endorsed an approach to urban planning and development that, in its words, 'takes the natural environment into account - and respects it', that 'plan[s] with nature' rather than against it (CPDR 1993, p.17). In this way, as political ecology scholars have long observed, 'nature' and 'environment' are treated as largely external to society and contemporary urbanization processes, as something to be managed and controlled through 'good planning' (Escobar 1996; Castree and Braun 1998; Braun 2002). Modest (and problematic) as the CPDR recommendations were, the election of the Progressive Conservative Party in Ontario in 1995 marked the beginning of a period of intense provincial-municipal restructuring and reform and the rolling-back of the Rae government's planning reforms. 
The 'Common Sense Revolution': Planning reform and/as 'actually existing neoliberalism'

It is impossible to know how the planning reforms passed by the Rae government in 1995 might have transformed the politics and practices of municipal planning in Ontario because only two short months after the reforms were enacted, Mike Harris' Progressive Conservation party was elected to provincial government in Ontario. By 1995, Bob Rae and the New Democratic Party in Ontario had become extremely unpopular, given the condition of the Ontario economy and its record debt and deficit amidst a Canada-wide recession. Harris was elected with a large majority government and it is no small irony that the suburbanization of Southern Ontario played a deciding role in the election's outcome. As Sewell explains, 'it was only a matter of time until the new communities in the [suburban] fringes found a strong political voice that was louder than that of the older compact city' (2009, p.182). Harris' 'Common Sense Revolution', (CSR) promising to cut the large provincial deficit accumulated under the previous government by lowering taxes and reigning in government spending, particularly on social programs, 'appealed to and reflected the values of the new suburbs and was seen as an antidote to the muddled approach of the Rae Government with its old, downtown values' (ibid). In the June election, his party won every seat in the suburban belt surrounding Metro Toronto (also known as the '905' region, in reference to its telephone area code) as well as half the seats in Metro Toronto.

According to Roger Keil (2002, p.240) the election of an 'uncompromisingly neoliberal provincial government' in Ontario, led by PC Premier Mike Harris and his successor Ernie Eves from 1995 to 2003 , 'created a political environment reminiscent of Thatcherism and Reaganism'. Epitomizing the era 'roll-back neoliberalism' (Peck and Tickell 2002), the CSR platform had a number of defining features, as summarized by Graham and Phillips (1998, p.177-178). The first, and perhaps most notable, they argue, was the promise of 'less government', getting government 
out of 'non-essential' activities and reducing direct involvement of the Province in program and service delivery. The second was its commitment to the idea of 'simpler government', which would be achieved through the reduction of overlap and duplication within and between different levels of government - the 'efficiency and effectiveness' of government, it was argued, would be improved through the 'elimination of waste' (ibid, p.177). The third was the CSR's overarching emphasis on fiscal austerity, which included, as already mentioned, an attack on the provincial deficit, while at the same time promising to cut the provincial income tax by 30 percent (ibid). These three features, argue Graham and Phillips, informed the fourth: the CSR's new 'competitiveness agenda' for Ontario, in which the Progressive Conservative party argued that 'With leaner, simpler fiscally tight-fisted government ... Ontario would once again be "open for business", (ibid, p.178).

The election of the Progressive Conservative party in Ontario, and the near decade of neoliberal governance and policy changes that followed, had significant and far-reaching implications for Ontario's cities, making 'dramatic incisions into the everyday lives of many people throughout the province' (Boudreau et al., 2009, p.59). Immediately upon election, the Harris government began to implement the most controversial elements of its neoliberal reform agenda. One of its first major policy decisions was to drastically cut social assistance rates by twenty-two percent, justified on the grounds that that too many people were taking advantage of the program, and that it served as a disincentive to recipients to seek employment. Shortly after, the Harris government introduced 'Ontario Works', often referred to as 'workfare', a program that required able-bodied welfare recipients to participate in either training or job placement, and legalized the 60-hour work week - a mark of the Harris regime's stubborn refusal to acknowledge the labour demands of the province's public and private sector unions (ibid). As 
part of the CSR, the government also made dramatic cuts to the province's heathcare system, including a series of hospital closures and the laying off of hundreds of nurses across the province, and introduced education reforms that, among other things, reduced the powers of school boards, including their authority to levy taxes. Although Harris' reform agenda left few areas of provincial policy untouched, particular attention is directed here to the Harris government's reforms experiments in the areas of land-use planning and housing, and in the restructuring of provincial and municipal responsibilities for urban infrastructure and services, the first having received comparatively little critical attention to date.

On November 15, 1995, just months after it's election win, the Harris government introduced Bill 20, the Land Use Planning and Protection Act, whose longer title - An Act to promote economic growth and protect the environment by streamlining the land use planning and development system through amendments related to planning, development, municipal and heritage matters - reveals the many tensions, contradictions and compromises associated with provincial land-use planning in an era of neoliberal governance and policy reform. For most environmental and other public interest groups that had supported the Rae reform package, Bill 20 was an unfortunate leap backwards. Unlike the CPDR process, Bill 20 was prepared and pushed through the Ontario legislature rapidly and without meaningful public involvement. The new piece of legislation gutted the Rae reforms and the Comprehensive Policy Statements passed with strong public support just months earlier and reintroduced the 'shall have regard to' measures, with the implication that municipal plans were no longer required to conform to provincial policy statements. The position of the Harris government was that the Rae reforms had been too heavy-handed, taking planning and decision-making authority away from municipalities; it amounted to, in the words of then Minister of Municipal Affairs and Housing, 
Al Leach, 'a basic difference in philosophy' (Legislative Assembly Committee Meeting, Bill 20, February 12, 1996). Planning decisions, it was argued, should be made by municipal authorities, not by Queen's Park.

As a piece of 'environmental' legislation, environmental organizations in Ontario challenged Bill 20 on several grounds, the most obvious of which was that, despite reference to environmental protection in the naming of the Act, not a single amendment in Bill 20 dealt with environmental protection. In fact, as CELA persuasively argued, there was, at the time, grave concern that several amendments introduced as part of the land-use reform package, when combined with the wholesale gutting of the Comprehensive Set of Policy Statements (concerning the preservation of agricultural land, natural heritage, and environmental protection), seriously undermined environmental protection in Ontario's planning system (CELA 1996, p.5). It was CELA's position that the 'shall be consistent with' standard, introduced under Bill 136, provided clarity and ensured the enforcement of provincial policy concerning environmental protection, making it possible for municipalities to say 'yes' to 'good development' and 'no' to development that is environmentally destructive - including, for example, development on provincially significant wetlands or floodplains, or development that contributes to low density suburban sprawl. Reverting to the old 'shall have regard to' standard meant municipalities could once again ignore provincial policy, and should they attempt to apply strong environmental measures to development decisions, they once again face appeals by the real estate development industry to the OMB (ibid, p.6). Moreover, CELA challenged the Harris government's claim that this reversal would put decision-making authority back into the hands of municipalities, arguing 'Removal of this essential tool to implement provincial policy will undermine the goal of municipal empowerment. Far from increasing flexibility, a return to "shall have regard for" will 
increase costs, confusion, uncertainty, inconsistency, delay and the frequency and length of OMB hearings' (ibid).

From the perspective of curbing sprawl, Harris' land-use reforms under Bill 20 and its new Provincial Policy Statement (PPS) removed numerous municipal powers and tools to encourage compact urban development, essentially loosening planning restrictions as part of an aggressive suburban growth strategy in Ontario. The Rae reforms, as part of Bill 163 , for example, prevented municipalities from standing in the way of two-unit housing development; this restriction was reversed under Bill 20. The new legislation also repealed the requirement that municipalities permit secondary apartment units in houses, passed by the Rae government's Residents' Rights' bill in 1994. Taken together, these measures marked the loss of important levers to encourage compact development, infill and intensification and to curb low-density suburban growth in Ontario municipalities. But also, the repeal of legislation permitting secondary rental apartments in homes, in particular, removed opportunities to add to the stock of affordable rental housing through small-scale neighborhood intensification. Given the drastic reduction in welfare payments already implemented by the Harris regime, the rolling-back of federal and provincial support for social housing programs and their implications for the everyday lives of low income families in Ontario, housing advocates argued in the Ontario legislature that 'A change in policy on accessory apartment legislation would have the effect of less private affordable rentals and would therefore be the final door closing on them' (Legislative Assembly of Ontario, 1996).

More broadly, not unlike the reforms passed by the previous government, there was an overarching emphasis placed on 'streamlining' planning in Ontario, a position that privileged the imperatives of growth and development over environmental or social 'considerations'. In the 
Ontario legislature, the Honourable Al Leach, then Minister of Municipal Affairs and Housing expressed this position succinctly: 'A streamlined process will mean faster decisions. That will cut the cost of development. Construction will be able to proceed, creating jobs and economic activity. Developers won't have to sit on valuable land, paying high carrying costs while waiting years for a decision' (Legislative Assembly of Ontario, 1996). To this end, the 1996 amendments to the Planning Act reduced provincial oversight in the review of site-specific development applications such as subdivision plans and some official plan amendments on the understanding that this would strengthen local decision-making and enable regions to further streamline the development approval process. Where the provincial government remained the approval authority, the new PPS required that provincial review be coordinated through new 'onewindow' procedure, giving municipal, private and public sector clients 'one-stop access' for provincial input, review and appeal services. In the new one-window approach, the Ministry of Municipal Affairs and Housing was given ultimate authority in the review and approval process, severely constraining the roles of the Ministry of the Environment and the Ministry of Natural Resources in the land-use planning process.

The Harris regime's unequivocal support for market-driven suburban development crystallized in its first provincial budget in March 1996, which included a land transfer tax rebate for first-time home-buyers of newly built homes. Since the rebate did not apply to first-time buyers of existing units, it provided an incentive to purchase new housing, typically outside existing urban areas, by creating a price advantage for such housing - a measure which Sewell describes as 'a simple way of subsidizing the expansion of suburbia' in Ontario's cities (Sewell 2009, p.183). A year later, in 1997, amendments to Ontario's Development Charges Act which significantly limited the ability of municipalities to require developers to internalize the costs of 
providing both 'hard' (transportation, water and sewer) and 'soft' (schools, libraries, social services) infrastructure for new developments through development charges, was also a boon for the suburban housing development industry. Other reforms in support of market-led suburbanization included reforms of the OMB. Among the reforms, the terms of OMB members were shortened to only a few years and 'more progressive members were not reappointed' (ibid, p. 183). According to Sewell, OMB was put on a 'short leash'; the 'OMB's new role seemed to be simply to approve [suburban] development' (ibid).

Another salient feature of the CSR that would go on to play an influential role shaping the politics of urban growth in the late 1990s in Ontario, was the Harris government's Local Services Realignment (LSR) reforms - otherwise referred to as 'downloading' - which began with the January 1997 'mega-week' restructuring of provincial and municipal responsibilities. The rationale and framework for this fiscal and administrative 'realignment' was based partly on the recommendations of the 'Who Does What?' panel, chaired by former Toronto mayor David Crombie, whose mandate it was 'to develop principles and make recommendations on how best to overhaul the funding and delivery of a wide range of provincial and municipal government services, including property taxation and assessment, social services, education, public health, and a variety of hard services, with the overall goal of reducing waste, duplication, and the overall cost of government' (Graham and Phillips, 1998, p.183). With this, the Harris regime began the realignment of provincial and municipal responsibilities in which financial responsibility for key services such as social housing, municipal public transit, and property assessment, previously funded by the provincial government, were transferred to local governments. In exchange, the Ontario government's education finance reforms transferred greater responsibility for education from municipalities up to the Province, though the 
'exchange' was by no means fair or equitable (ibid). Compounded by the trend of decreasing federal and provincial transfer payments to Ontario municipalities, this new provincial-municipal relationship radically transformed and destabilized the everyday lives of Ontario's most vulnerable residents and has had far reaching implications for municipalities and would later be used to justify the restructuring of municipal governance as a solution to these changes.

The 'realignment' of responsibilities for affordable housing in Ontario drew from the same neoliberal script that prompted the progressive withdrawal of the federal government in Canada's affordable housing sector beginning in the mid 1980s. To recall, between 1984 and 1993, the federal Conservative government cut almost $\$ 2$ billion from its housing programs and, in 1993 , cancelled funding for new co-op and non-profit housing (Shapcott 2006, p.30). In 1993, the newly-elected Liberal government, which had promised to restore funding for Canada's national housing program, failed to follow through and, in 1996, announced its plans to transfer existing federal housing programs to the provinces and territories - a policy shift that, in effect, removed the federal government from the nation's housing sector, 'making Canada one of the only developed countries in the world without a national housing program' (Cormier 2009, p.30).

Although the federal government had, historically, played a leading role in the provision of affordable housing, the province of Ontario had a clear mandate, under the Planning Act, concerning the provision of affordable housing as part of the municipal planning process. The 1989 Provincial Policy Statement encouraged all Ontario municipalities to create legislation requiring that a minimum of twenty-five percent of new housing units, created through either new development or intensification, be affordable. On the recommendations of the CPDR, this target was increased to 30 percent in the 1995 Provincial Policy Statement. Despite this, even before the devolution of federal responsibility for affordable housing had been implemented in 
Ontario, the Harris government made clear its intentions concerning housing policy. Part of Harris' Common Sense Revolution election platform was, in fact, to get the Province 'out of the housing business' (Shapcott 2001, p.11). In 1995, the same year that it cut welfare rates by twenty-two percent, the provincial government cut approximately 17,000 units of co-op and nonprofit housing that were under development (ibid). In 1996, a new Provincial Policy Statement enacted under Section 3 of the Ontario Planning Act led to the removal of the twenty-five percent minimum for affordable housing. The implication of this 'omission', as Cormier (2009, p. 31) argues, was that there was no longer a directive from the Province to ensure that any fixed proportion of new housing units developed in Ontario cities were affordable. Between 1996 and 1998, the provincial government repeatedly cut funding to existing social housing projects in the province. In 1998, as part of the 'realignment' of provincial and municipal responsibilities, the Province downloaded the $\$ 905$ million in social housing costs to Ontario municipalities, and in 2001 transferred the administration of social housing to the same (Shapcott 2001, p.11).

Although the rationale in support of the realignment of responsibilities for affordable housing may have been sound - that local government was closest to the people and therefore could be most responsive to people's everyday needs - municipalities were ill-equipped to meet these new responsibilities. As Cormier (2009, p.31) explains:

In offloading costs, the provincial and federal governments did not provide either a legislative or practical framework in which municipal governments could easily sustain the pre-existing housing supply or procure revenue to establish new units. The lack of framework provided to municipalities placed a significant amount of pressure on non-residential property taxes and development charges, ultimately increasing the costs for developers of building new affordable social housing. While the municipal government inherited a new set of responsibilities, the legal framework in which municipalities were working within (both local and provincial) remained static, causing a number of difficulties in replenishing or generating affordable housing stock. 
The downloading of affordable housing programs (as well as other programs and services) to municipalities without also transferring new funding and/or revenue generating authority to municipalities to maintain existing housing stock and invest in new affordable housing development is suggestive of what Byron Miller (2007) refers to as a situation of 'mismatched rescaling'. This rescaling of responsibilities, a defining feature of neoliberal urban governance regimes, has been the virtual 'throttling [of] Ontario's vibrant social housing sector' (Shapcott 2001, p.3), placing greater pressure on an already-dwindling rental market in many cities across Ontario to meet the housing needs of the province's low income families.

Before the 1970s, Canada had a thriving rental housing market because federal tax incentives made investment in rental housing development quite attractive - for example, 'capital cost allowances for depreciation were in excess of true economic depreciation, rollover provisions enabled the postponement of recaptured depreciation on the sale of an investment property, capital gains were not taxed, and book losses were deductible against other income' (Smith 1983, p.61). However, in 1972, Canada's tax structure underwent significant revision; incentives for investment in rental housing were eliminated, and new taxation provisions (including the introduction of a capital gains tax on all assets except a principal residence) increased the attractiveness of homeownership over rental housing (ibid, p.64). In 1970, the Canadian federal government also introduced legislation permitting condominium ownership - a shift in policy which dramatic implications for new rental housing development in Canadian cities (Hulchanski 2002, p.16). As Hulchanski explains, ' $[\mathrm{g}]$ iven that condominiums were now possible, and a developer could get an immediate return on investment once the [apartment] units were sold, why would anyone build rental apartment buildings? Since this time, investment in rental housing across Canada has declined dramatically, creating a severe shortage in 
affordable rental units in the housing market, particularly in the Canada's larger urban centres - a situation which has been exacerbated by the Harris reforms.

The Harris government had already repealed provisions in the Planning Act permitting the creation of secondary rental units in Ontario homes in 1995. With an unshakable faith that market was the answer to solve the growing housing crisis in Ontario, the Harris regime undertook a radical experiment to stimulate the private rental market by deregulating the private housing sector in the province. The assumption was that a more lucrative rental housing market would attract private developers back to the rental housing market, encourage the construction of new rental housing and improve the supply of affordable rental units. This policy experiment entailed the 'gutting' of tenant and housing protection laws by the provincial government in 1998 (Shapcott 2001, p.9). Rent controls were abolished, permitting developers and landlords to charge whatever rents they desired once units became vacant, creating an incentive for property owners to evict tenants. The new so-called Tenant Protection Act, introduced by the Harris government, also created a 'fast-track eviction process' that removed the requirement that tenants be entitled to a court hearing before facing eviction (ibid, p.4). Not unexpectedly, the deregulation of the private rental market worsened an already tenuous housing situation in Ontario:

In fact, over six years there has been virtually no net gain in the number of rental units in most parts of the province. Many areas have suffered a net loss. And tenants have been walloped with year after year of rent increases that have often been well above the inflation rate. Ontario tenants paid $\$ 338$ million more to private landlords in 2000 over 1999, but almost none of that money was reinvested in new rental housing. Since the election of the Harris government in 1995, the private development sector has got almost everything that it has asked for: higher rents, reduced regulation, lower municipal taxes, direct grants and subsidies. But the private sector still isn't building. And the reason is simple: there's no profit to be made from building housing for low and moderate income tenant households. (Shapcott 2001, p.11). 
As a result of massive cuts in welfare payments (including shelter allowances) and the elimination of rent controls by the Harris government, eviction rates rose dramatically; 'More than 60,000 tenant households in Ontario faced eviction in the year 2000, with more than 40,000 of them losing their homes without even a formal hearing under the fast-track eviction process created by the Harris government' (ibid, p.9).

Overall, the lack of new rental housing construction, compounded by conversion of rental units to condominiums and commercial uses, lead to net loss in rental housing in Ontario during the Harris years. Ottawa's rental housing market was particularly hard hit. In 2000, Ottawa had the highest increase in average rents in Canada, 'a staggering $12.6 \%$ increase from $\$ 783$ in 1999 to $\$ 882$ in 2000 ', while also recording the lowest rental vacancy rate at $0.2 \%$ - that's two vacancies for every 1,000 rental units in the city' (ibid, p.5-6). According to Shapcott, 'the dangerously low rental vacancy rate [was] an all- time low for the city' (ibid).

In keeping with the downloading ethos of the roll-back phase of Harris' neoliberal reforms, Harris's 'mega-week' announcements also included the Province's withdrawal from the provision of capital and operating funds for urban public transit and sewer and water infrastructure. Provincial grants in $1996 / 97$ had totaled $\$ 718$ million for transit and $\$ 140$ million for sewer and water infrastructure (Winfield 2003, p.16) - sizable expenditures that would now be borne by limited-capacity municipal governments.

While no doubt affecting all municipalities, it is noteworthy that the Harris reforms, and their impacts, were not evenly distributed across the landscapes of Ontario's cities. Suburban municipalities in the province, for the most part, had few social housing units and public transit was comparatively limited; given this, the Harris reforms passed with little contest from 
Ontario's suburban communities. The rolling-back of provincial support for urban infrastructure and services, like affordable housing and transit, Sewell $(2009$, p.183) argues, was directed at Ontario's older, and historically Liberal, inner cities where affordable housing and transit use have, historically, been concentrated. In all of these ways, the early Harris reforms were undeniably regressive, targeting the most vulnerable in Ontario's cities and radically undermining the potential for a more environmentally and socially progressive approach to municipal planning and development in Ontario of the kind envisioned by the CPDR recommendations and planning reforms passed by the previous Rae government.

To deal with the changes wrought by the 'realignment' of provincial and municipal responsibilities - in short, to make downloading 'work' - the Harris government pressed the need for municipal restructuring in Ontario. Although municipal restructuring was not an explicit component of the CSR election platform in 1995, it was consistent with the CSR promise that 'regional and municipal levels' of government should be 'rationalize[d] ... to avoid overlap and duplication that now exists', and that 'we will sit down with municipalities to discuss ways of reducing government entanglement and bureaucracy with an eye to eliminating waste and duplication as well as unfair downloading by the province' (Progressive Conservative Party of Ontario 1994, cited in Sancton 2000, p. 135). The Province's framework for municipal restructuring was outlined in Bill 26, the Savings and Restructuring Act, first introduced in late 1995. Schedule M of Bill 26 defined municipal restructuring in terms of different forms of annexation and amalgamation. It established a procedure for municipalities to arrive at locallyagreed restructuring arrangements and provided for the appointment, in case of local disagreement, of a commission which would itself have the power to impose new boundaries and structures which the affected area' (ibid, p.136). In 1996, the Ministry of Municipal Affairs and 
Housing released its Guide to Municipal Restructuring to help municipalities explore restructuring alternatives and to develop restructuring proposals (Fischler et al. 2004, p.94). As Fischler and colleagues explain, it proposed five principles that municipalities were to strive for in their restructuring efforts: (1) less government resulting from fewer municipalities and fewer politicians; (2) an accessible and accountable representation system; (3) efficient service delivery resulting from reduced overlap and duplication of programs and personnel; (4) municipal selfsufficiency by delivering municipal services funded by municipal revenue sources; and, (5) sustainable economic growth and development (ibid). The municipal restructuring provisions of Bill 26 concerned only single-tier municipalities and as such excluded any part of the province governed by a two-tier metropolitan, regional or district government, in part because some were already in the process of restructuring while others, including the region of Ottawa-Carleton, had only recently completed their own restructuring efforts (Sanction 2000, p.138).

The amalgamation of Metropolitan Toronto in January 1998 was passed through the City of Toronto Act, and has been, by all accounts, the most contested of all municipal restructuring efforts as it was seen by most reform critics as a 'forced amalgamation', initiated and legislated by the Province and not by the municipality itself. Other two-tier governments, including Ottawa-Carleton, were unaffected by the Harris government's municipal restructuring activities until late 1999, when Bill 25, the Fewer Municipal Politicians Act, was passed by the Ontario legislature requiring that two-tier governance systems in place in Ottawa-Carleton, HamiltonWentworth, Sudbury, and Haldimand-Norfolk be restructured into single-tier amalgamated municipalities (Fischler et al. 2004, p.95). These too were considered 'forced amalgamations', with special advisors appointed by the Minister of Municipal Affairs and Housing to decide the best alternative for municipal restructuring in these areas. In each case, the establishment of a 
'megacity' through the amalgamation of the regional government and the area municipalities was recommended. The passage of Bill 25, formally established the cities of Ottawa, Greater Sudbury, Hamilton, and the towns of Haldimand and Norfolk, beginning January 1, 2001.

Although municipal restructuring was branded by the Harris government as a means to achieve greater cost savings and to improve the efficiency and effectiveness of municipal governance and service delivery, it was, more precisely, a financial imperative brought on by the Province's downloading measures (Sanction 2000). In the end, though, the restructuring of municipalities across Ontario, by and large, did not save money, at least not for municipalities (Sancton 2006, p. 317). While the twin projects of provincial-municipal service realignment and municipal restructuring resulted in 'windfall savings for the province', municipal governments in Ontario have been forced to 'pick up the difference' through increased property taxes and user fees for essential services given the limited authority afforded to municipalities to levy taxes and generate other sources of revenue (Graham and Phillips 1998, p.181). As a consequence of these reform and restructuring measures, urban politics in Ontario municipalities has become an increasingly contested arena of struggle given escalating property taxes, deteriorating service delivery, weakened environmental protection, and declining quality of life leading provincial and municipal levels of government in search of a fix.

\section{Conclusion}

This chapter examines the recent history of provincial-municipal restructuring and planning reform experiments in the Province of Ontario between 1991 and 2001. As early as 1991, urban and regional sprawl had become a pressing public policy issue leading the Liberal Rae government to establish the CPDR to study and draft recommendations to reform Ontario's planning system and craft policies geared toward curbing environmentally destructive and 
fiscally unsustainable low-density suburbanization and promoting more compact, mixed use, transit- and pedestrian-oriented development patterns in Ontario's cities. The election of the Conservative Harris government in 1995, however, ushered in a period of intense change in Ontario. After repealing the Rae reforms passed by the Ontario government just months before, the Harris regime initiated a process of dramatic provincial-municipal restructuring characterized by deep cuts to social programs and services followed closely by the downloading of key provincial responsibilities for key infrastructure and services to municipalities. It is within this broad context of neoliberal governance and policy reform that the Harris government announced its 'Made-in-Ontario' smart growth planning reform agenda in 2001. In the next chapter, and throughout the remainder of thesis, I argue that 'smart growth' provincial and municipal reform experiments in Ontario, since 2001, must be situated within, and have been highly conditioned by, this broader context of political economic restructuring and governance change. 


\section{Chapter 5}

\section{The 'rolling out' of a new 'smart growth' planning regime in Ontario}

\section{Introduction}

In the wake of dramatic provincial-municipal restructuring since 1995 , the subject of Chapter 4 , this chapter examines the emergence of a new 'Made-in-Ontario' 'smart growth' planning regime in Ontario, introduced by the Conservative Harris-Eves government in 2001 . As While et al. (2004) observe elsewhere, the Harris-Eves government's smart growth agenda - geared toward reining in regional sprawl and promoting 'environmentally-sensitive' and 'sustainable' approaches to urban development in Ontario municipalities- appears to conflict, discursively and materially, with the 'growth first' urban politics that accompanied the rise of urban neoliberalism in the province since the mid-1990s. Reminiscent of the kind of 'fast urban policy' regime that Jamie Peck (2005) has observed in other policy areas, the argument developed in this chapter is that 'smart growth', in fact, has become a key feature in the 'rolling out' of a new, highly interventionist, wave of neoliberalization in Ontario through which the Harris-Eves and subsequent McGuinty governments have sought to manage and displace the social, economic and ecological crises brought about by earlier phases of its own neoliberal restructuring efforts not the least of which include, the deterioration of municipal infrastructure, growing income disparities, homelessness, traffic gridlock, environmental decline, and persistent budget crises in Ontario's municipalities - while simultaneously capitalizing on new opportunities to promote the economic competitiveness of Ontario cities.

Specifically, the chapter develops the argument that the Harris-Eves' smart growth planning reform agenda appears to constitute, in part, a tactical response on the part of the 
Province to ensure that future new urban development is as efficient and cost effective as possible, thereby reducing financial pressures on already fiscally-constrained municipalities following more than a half decade of provincial-municipal restructuring in Ontario. But more than this, building on recent insights in urban political ecology (Keil and Desfor 1996; Keil and Graham 1998; Bunce 2004; While et al. 2004; Jonas and While 2007), I argue that this new planning regime which espouses the protection of Ontario's unique urban and regional environments and creation of more 'vibrant', livable', and 'sustainable' urban landscapes has also been mobilized as part of a larger entrepreneurial strategy through which the Province of Ontario has actively sought to bolster the competitiveness of Ontario cities, making and marketing them as good places to live and invest in the new knowledge economy. In this respect, I argue, smart growth is suggestive of the kind of 'win-win' discourse that lies at the very heart of the contemporary politics of ecological modernization (Harvey 1996, p.378). My intention, however, is not simply to draw attention to the ways in which smart growth, and dominant interpretations of urban environmental 'sustainability', have coincided with recent neoliberal policy transformations; rather, it is to suggest that, in a very real sense, smart growth, as a new environmental governance regime and planning reform experiment, has been constitutive of a new wave of neoliberal urbanization in Ontario.

\section{Urban entrepreneurialism and the 'greening' of Ontario planning}

By the beginning of the $21^{\text {st }}$ century, in what seemed a surprising turn given recent trends, the provincial government announced a new 'Made-in-Ontario smart growth strategy'. Having deregulated much of Ontario's planning system in 1995 - including the repeal of key planning reforms flowing from the report of the CPDR that placed a strong emphasis on curbing sprawl, 
protecting prime agricultural lands and ecologically significant areas, and promoting compact, mixed-use development patterns that were supportive of transit and affordable housing - the Harris-Eves ${ }^{1}$ government's championing of 'smart growth' no doubt came as a surprise to many. Superficially, the Harris' 'Made-in-Ontario' smart growth agenda appeared to conflict, ideologically and materially, with the 'growth first' urban politics that accompanied the rise of urban neoliberalism in Ontario. However, a more critical reading suggests that Ontario's new 'smart growth' planning regime has become a key feature in the 'rolling out' of a new phase of urban neoliberalization in Ontario. Following Brenner and Theodore (2002, p.27), while the neoliberal imperative of mobilizing city space as an arena for growth and market discipline remains, 'roll-out neoliberalism' establishes 'flanking mechanisms' and 'modes of crisis displacement' as part of a carefully-crafted strategy to manage the contradictions and crises brought about by earlier 'roll-back' phases (2002, p.27). One of the defining features of 'rollout' neoliberalism in Ontario, from the 2001 forward, has been the selective (and strategic) incorporation of environmental and social goals into the Harris-Eves government's 'smart growth' provincial planning reform experiment. As a new planning regime, the argument developed here is that 'smart growth' provided the Harris-Eves and later McGuinty governments with what While et al. (2004) refer to as a 'sustainability fix', an urban growth and development strategy capable of promoting economic competitiveness, while at the same time enabling municipalities to negotiate the complex environmental and fiscal pressures facing them in the early years of the new millennium.

\footnotetext{
${ }^{1}$ In early 2002, Mike Harris stepped down as leader of the Conservative Party in Ontario. Ernie Eves, former Finance Minister in the Harris government, was elected leader of the Progressive Conservative Party and was sworn in as Premier of Ontario on April 15, 2002. Although the Province's Smart Growth Strategy was introduced first by the Harris government, it was advanced by the government of Ernie Eves until 2004.
} 


\section{(Anti-)Sprawl politics in Ontario}

By the late 1990s, following the repeal of planning and environmental legislation passed as part of the Rae reforms, the Harris government faced mounting opposition from powerful coalitions of environmental and citizen-based groups, including the Federation of Ontario Naturalists (now Ontario Nature), the Sierra Club of Ontario, the Nature Conservancy of Canada, Earthroots and the CELA, to name but a few, exerting intense pressure on the Province to reintroduce planning reform restricting low density suburban expansion in Ontario. Of particular concern, at the time, was the impact of on-going suburban development in ecologically fragile areas like the Oak Ridges Moraine north of Toronto. The moraine boasts extensive green open space and forests and is rich in biodiversity, but is particularly valued for its hydrological functions. Often called 'Southern Ontario's rain barrel', it contains the headwaters of a number of important rivers and a quarter of a million people in the region rely on the aquifer beneath the moraine for their drinking water. Given this, the moraine had become the site of a decade-long regional struggle in which environmental groups, farmers and residents, as part of the Save the Oak Ridges Moraine (STORM) coalition (Figure 4.1), have fought to protect the moraine from future development, calling on the Harris government to declare the moraine a provincially significant natural feature, restricting future development on the moraine by act of provincial legislation (Wekerle 2001). 


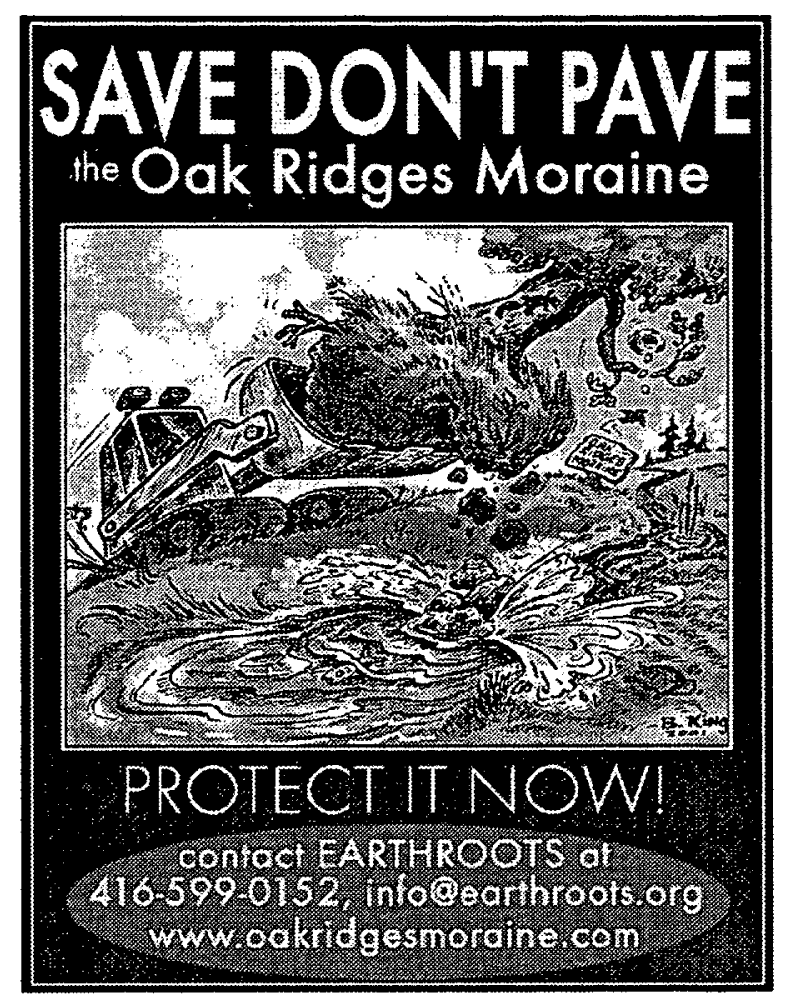

Figure 5.1 Save Don't Pave the Oak Ridges Moraine. Earthroots, 2001.

Importantly, concerns about the ecological consequences of sprawl, at the time, were also broadened to include issues of air quality and climate change, as well as public health issues that have been increasingly linked to patterns of low density, automobile-dependent urban development in Ontario, as elsewhere in North America. In 2001, Pollution Probe reported that vehicles in Ontario constituted the single largest source of carbon dioxide emissions, a known contributor to climate change, and contributed as much as forty percent of the pollutants that make up smog in Ontario cities (Pollution Probe, 2001, p.8). As Ontario residents became more reliant on private automobiles for daily transportation, as a result of on-going low-density suburban expansion, air pollution emerged as a significant public health concern. Air pollution, in the form of smog, has been found to cause bronchial infections, aggravate cardiac diseases, increase the frequency and severity of asthma attacks, irritate eyes and decrease immune 
function. In 2000, the Ontario Medical Association reported that air pollution caused approximately 13,000 visits to hospital emergency rooms, 9,800 hospital admissions, and 1,900 premature deaths each year in Ontario (OMA 2001, cited in Sierra Club 2003, p.11). Reports highlighting the impacts of sprawl on air quality and the health of Ontarians received considerable public attention in the 2000/01 fuelling already intense opposition to the Province's permissive land use planning system. The consolidation and strengthening of an new 'antisprawl' environmental politics, at the turn of the millennium, saw the formation of new political mobilizations pressing for comprehensive planning reform renewing the Province's commitment to encouraging compact, mixed use and transit-supportive growth and development in cities across Ontario.

A new 'urban agenda' in Canada: competitiveness, quality of life, and the urban environment The Province's 'Made-in-Ontario' smart growth regime also, and quite crucially, coincided with a series of policy shifts by the federal Chrétien government. By 2001, more than a decade and a half of federal and provincial level political-economic restructuring, which saw the steady withdrawal and transfer of federal and provincial responsibilities for municipal infrastructure and service provision to local governments, had taken a toll on Canadian cities. Burdened with responsibilities beyond their means, municipalities could not maintain levels of investment in critical urban infrastructure and services, resulting in a rapid decline in quality of life in Canada's cities in just a few short years. The Federation of Canadian Municipalities (FCM) quality of life reporting, for example, found that between 1991 and 2001, Canadian municipalities were confronted with growing poverty and a widening of income disparities, and points to the severe lack of affordable housing as a prime cause of economic hardship among Canada's most 
vulnerable populations (FCM 2004). Cuts in social assistance, combined with a lack of government investment in new social housing, narrowed the housing options for low-income families and singles, leading to a situation of escalating homelessness in municipalities across Canada. On the flip side of the coin, as home ownership rates improved for families of higher income, the FCM reports significant growth in lower density forms of residential development, such as detached and semi-detached housing, rather than multi-unit condominium or rental apartment buildings, in many cases contributing to regional sprawl, increased infrastructure costs, traffic congestion, limited use of public transit, and loss of downtown vitality in municipalities across Canada (FCM 2006b, p.ii).

Quality of life in Canadian municipalities became a matter of intense federal policy interest at the beginning of the $21^{\text {st }}$ century given a shift in thinking, particularly among OECD countries, concerning the growing importance of city regions to the economic well-being of nations. In the second-half of the twentieth century, in countries such as Canada, globalization transformed the economy from one built around agriculture, natural resource exploitation and secondary manufacturing, to one based increasingly on services and knowledge-based industries, such as business, finance, biotechnology, information and communication technologies, and fibre-optics to name but a few. Knowledge-intensive industries, such as these, rely on state-ofthe-art infrastructure, access to public and private research institutions, and a highly educated and technically proficient labour force and as such prefer to concentrate in large urban regions where these are robust and plentiful. In an era of rapidly expanding and intensifying global interurban competition, a city's ability to attract and retain innovative 'industry clusters' is understood to depend on strategic and sustained investment in the kinds of high quality urban infrastructure necessary for innovation. Urban competitiveness is also, and quite crucially, said 
to depend on a city's ability to attract the young knowledge workers - the software developers, management consultants, scientists, artists, engineers, web designers, policy analysts and so forth - what Richard Florida (2002) refers to as the 'talent', the 'creative class', whose creativity and innovativeness are said to ultimately drive the new knowledge economy. According to Florida, such talent is highly mobile and seeks out cities that promote cultural diversity, offer unique lifestyle and recreational amenities, and boast high quality urban environments, including historic neighbourhoods and built forms as well as natural landscapes. In this new economy, it is not simply that 'place matters'; in a global competition to attract talent, capital and new knowledge industries the 'quality' and 'uniqueness' of place becomes a defining feature of urban competitiveness (Bradford 2002, p.7).

In early 2001, the Chrétien government convened the Prime Minister's Caucus Task Force on Urban Issues to examine the complex challenges facing Canadian cities at the beginning of the $21^{\text {st }}$ century. It argued that the competitiveness of Canada's urban regions, and the nation as a whole, was being stifled given more than a decade of federal and provincial disinvestment:

There is mounting evidence that our cities are ailing due to deteriorating infrastructure, declining air and water quality, traffic gridlock, homelessness, growing income polarization and marginalization, and budget crises. With few ways to generate revenue other than through property taxes, urban regions are finding it increasingly difficult to provide basic services and make repairs to infrastructure (Government of Canada, 2002, p.2).

In a report entitled Early Warning: Will Canadian Cities Compete?, the FCM (2001) likewise argued that new fiscal challenges facing cities, brought on by more than a decade of federal and provincial downloading, has left cities unable to maintain levels of investment in infrastructure and services critical to sustaining long-term economic growth and urban environmental quality. In an unanticipated twist of political irony, the long-term competitiveness of Canada's urban 
regions was being systematically eroded by the political-economic, social and ecological dislocations of the government's own neoliberal reform and restructuring efforts. Yet, unsurprisingly, the cure for what ailed Canada's municipalities would be found not the dismantling of neoliberalism, but rather, in its strategic redeployment. If the $1990 \mathrm{~s}$ were emblematic of what Peck and Tickell (2002) have termed 'roll-back neoliberalism', the early years of the new millennium brought about a highly interventionist 'roll-out' phase in neoliberal urban politics in Canada - a politics that etched the contours of Ontario's 'smart growth' planning reform experiments in direct and consequential ways.

The Prime Minister's Task Force argued persuasively for a comprehensive national urban strategy, coordinated among all levels of government to address the perceived 'crisis' threatening Canadian municipalities. Although poverty, the lack of affordable housing, and environmental problems ranked high on political agendas, the task of ensuring that Canada's large urban regions become economically competitive the $21^{\text {st }}$ century global economy was privileged above all else (Wolfe 2003). The publication of Canada's Urban Strategy: A Vision for the $21^{\text {st }}$ Century (2002) drew heavily on ideas of the 'competitive' and 'entrepreneurial city' that have come to define more recent waves of urban neoliberalism in Canada, as elsewhere:

Our cities compete with more than 300 city regions worldwide, everyday. These competitor regions are where innovation flourishes, where new economy industries thrive, and where the globe's best talent reside. Their strength drives the success of their national economies. Canadian city regions must be able to compete internationally - it is clear that the future prosperity of our country depends on it ...

Canada's evolution to an urban economy has put pressure on all urban centres to sustain economic development and growth. For the country to be economically competitive on a global scale, cities must attract the most innovative and dynamic entrepreneurs and companies. Companies are looking for centres of learning and innovation, skilled workers, upgraded infrastructure, a competitive cost of doing business and the highest quality of life. To compete globally, our urban areas must 
have the appropriate balance and appeal of infrastructure, amenities and high environmental quality (Government of Canada 2002, p.9).

Ensuring the competitiveness and long-term prosperity of Canada's urban regions, it was argued, required a renewed and sustained commitment, by all levels of government, to invest in the rehabilitation and modernization of the nation's ailing municipal infrastructure. But more than this, it would require a new approach to urban and regional planning - an approach committed to enhancing and marketing the 'vibrancy', 'livability' and 'sustainability' of Canada's urban regions as part of a strategy of urban competitiveness. In an effort to elaborate a vision and set of policy directions to guide federal debate and decision-making on the matter, Canada's National Roundtable on the Environment and the Economy (NRTEE) launched an initiative on urban sustainability in 2002. Echoing the 'competitive city' mantra of the Prime Minister's Task Force on Urban Issues, the NRTEE argued the strategic value of quality of life and, more specifically, 'urban environmental quality' to competitiveness in the new millennium. It was NRTEE's position that 'as the global economy shifts towards the clustering of knowledge-based industries ... quality of life in cities is becoming a prime determinant of investment decisions and, hence, the attraction of knowledge workers' (NRTEE 2003a, p.v). More specifically, it asserted:

Urban environmental quality is important to attracting and retaining the talent that drives wealth creation in knowledge-based economies. ... Skilled workers look for communities with a concerted approach to sustainable development that includes specific attributes such as user-friendly public transit; commuter bike lanes; a clean, healthy environment; and a commitment to preserving natural resources for enjoyment and recreation (ibid, p.4).

As part of the discourse of urban entrepreneurialism, 'quality of life', 'urban sustainability' and 'environmental quality' become strategic economic assets in the competitive quest to attract capital investment and talent in new knowledge economy. Both the NRTEE and the Prime 
Minister's Task Force on Urban Issues stressed the need for federal and provincial investment and incentives supportive of more sustainable patterns of urban growth and development. Both identify 'smart growth' as a key urban strategy for the $21^{\text {st }}$ century. The NRTEE argued, for example, that smart growth and the redevelopment of brownfields is important to cities to the extent that it results in more compact and efficient growth: 'Compact growth provides a competitive advantage to cities because it reduces the cost of infrastructure and increases urban livability. The development of brownfields is also important to municipalities because it could increase economic activity and property tax revenues' (NRTEE 2001 cited in Caucus Task Force on Urban Issues 2002, p.34). As part of a neoliberal competitive city strategy, smart growth appears to offer all things at once. At a time when municipalities are burdened with new responsibilities for infrastructure and services, smart growth offers a more compact, efficient and cost-effective approach to urban development and 'growth management', while still supportive of growth in the form of downtown revitalization and redevelopment strategies intended to attract investment and talent to cities and preserve greenspaces both for their natural and urban amenity value. Also noted at the time was the potential for 'smart growth' municipal planning to play a key role in meeting Canada's commitment under the Kyoto Protocol.

Although the federal government lacks jurisdiction to make urban policy, as part of Canada's new urban strategy, the Chrétien government, both in renewing a federal commitment to municipal infrastructure spending and in establishing a 'strategic framework' and set of 'policy directions' concerning Canada's urban regions, shifted the terrain of urban politics in the early $21^{\text {st }}$ century. In its 2000 budget, the federal government committed funds to a number of physical infrastructure programs, including $\$ 2$ billion for the Infrastructure Canada program, and $\$ 125$ million for the Green Municipal Enabling and Investment Funds. This was followed in 
2001 by a commitment of $\$ 2$ billion to a Strategic Infrastructure Fund, and in 2003 with an additional commitment of $\$ 3$ billion over ten years for infrastructure (Winfield 2006, p.18). While no doubt lauded by provincial and local governments as a step in the right direction, the new federal commitments were modest when compared to the scale of investment by provinces and municipalities in municipal infrastructure across the Canada. Moreover, with the exception of the funds allocated to the Green Municipal Funds programs, little if any of this new support was earmarked for sustainable infrastructure projects.

Urban brownfields, in particular, became an area of intense federal policy interest in Canada at this time. Often located in inner urban downtown areas, brownfields are those 'abandoned, idle or underutilized commercial or industrial properties where past actions have caused known or suspected environmental contamination, but where there is an active potential for redevelopment'; they include decommissioned refineries, former railway yards, old waterfronts and riverbanks, crumbling warehouses, abandoned gas stations, former drycleaners and other commercial properties where toxic substances may have been used or stored (NRTEE 2003b, p.ix). Brownfield remediation and redevelopment was considered a yet untapped opportunity to reduce regional sprawl (by reducing development pressures in suburban and rural areas), to clean up and improve the environmental quality (and the 'green' image) of high value urban districts, and to create new economic opportunities by opening up urban land to new waves of reinvestment - all of which were argued to enhance the competitiveness of Canadian cities (ibid). In 2001, the Chrétien government mandated the NRTEE to prepare a National Brownfield Redevelopment Strategy. However, given the complex market-based challenges associated with brownfield remediation (including the high cost of remediation, regulatory 
liability risk, civil liability risk and the difficulties in securing insurance protection), a national strategy is yet to be formally implemented by the Canadian government.

Without diminishing the progress made in securing a place for matters of environment and sustainability in debates concerning Canada's possible urban futures, the crucial point here, I believe, is that discourses of urban environmental 'sustainability' have been selectively and strategically deployed by the federal government as part of an increasingly neoliberalized entrepreneurial agenda which, while opening up, has also narrowly delimited, the terrain of urban environmental politics and planning reform in provinces like Ontario.

\section{The Harris government's 'Made in Ontario' smart growth planning regime}

In 2001, the Ontario government began to experiment with planning reform premised on the contemporary planning discourse of 'smart growth'. As discussed earlier in this chapter, interest in curbing sprawl through strategies of 'urban containment' and 'growth management' were not new to Ontario, having been first introduced as part of the CPDR review of Ontario's planning system and the reforms passed by the Rae government in the mid-1990s. These reforms were quickly repealed following the election of the Conservative Harris government in 1995, only to be reconsidered and partially resurrected by the same government five years later, with the announcement of a new 'Made-in-Ontario Smart Growth Strategy'.

By 2001, smart growth had become highly popularized, even trendy, in urban policy and planning circles across much of Canada and United States. Yet, from the outset it was clear that the Harris government's reform intentions constituted a partial and highly selective interpretation of 'smart growth'. In place of the more comprehensive suite of planning policies - that promote higher density, mixed use urban development, more diverse and affordable housing choices, and 
more 'complete', transit and pedestrian-friendly urban neighbourhoods - the Harris' government's new smart growth initiative was to become a centerpiece in the rolling out of a new phase of neoliberalization in Ontario, one in which land-use planning would be made to serve an unambiguous competitive/entrepreneurial city agenda constructed around the imperatives of ecological modernization and the partial 'greening' of urban growth politics in the province. Echoing the federal government's competitive city ethos, Premier Harris describes his government's vision for 'smart growth' in this way:

I am determined to see our children inherit cities, communities and neighbourhoods an entire province - that is as efficient, that is as strong as possible and that has a quality of life second to none ... Our vision will help encourage growth. It will make sure that all regions of Ontario - from our smallest towns to our largest cities can reach their economic potential. And it will help keep Ontario strong, growing and ready to compete in the $21^{\text {st }}$ century (Government of Ontario, 2001, p.2).

The Province's 'smart growth' manifesto was triumphant in tenor, promising to deliver a new era of growth and prosperity to Ontario cities. In terms of land use planning, what is perhaps most striking is that Ontario's smart growth strategy appeared to have little, if anything, to do with halting or even limiting growth. While critical of traditional suburban growth patterns that have proved costly and inefficient to service with infrastructure, Harris' 'made-in-Ontario' strategy was ultimately concerned with how best to manage, safeguard and sustain growth in Ontario municipalities in the long term. In keeping with script of contemporary neoliberalism, the idea that 'growth' was both inevitable and good, remained wholly unchallenged:

Growth is a good thing. It generates new businesses, new jobs and the revenue we need to support health care, education and all the programs that equate with a high quality of life.

We want to promote growth in our towns, cities and rural areas. At the same time, we want to manage growth to prevent undue pressure on our environment and to make 
sure that we have the infrastructure such as roads, public transit and water and sewer systems to meet the needs of our communities.

Smart Growth is the Ontario government's vision for doing both - for promoting and managing growth - in ways that create strong economies, build strong communities, and promote a healthy environment.

Our vision will lead to strategies that address growth challenges, such as preserving natural areas, reducing traffic gridlock in cities and creation new prospects for youth in northern and rural communities. Smart growth will also help us take advantage of the many opportunities for growth that our province offers (Government of Ontario 2002, p.1, emphasis in original).

Bearing little resemblance to the more comprehensive and potentially progressive set of urban policy and planning reform measures often associated with 'smart growth' in North America (for example, see Katz 2000; Kalinosky 2001), the provincial government's 'Made-in-Ontario' strategy was largely concerned with enhancing the competitiveness of Ontario municipalities. Directing growth away from undeveloped greenfields to existing built-up areas in Ontario cities enabled the Province to pursue an aggressive economic strategy bent on making future urban growth as efficient and cost-effective as possible, while also, and quite critically, stimulating the revitalization of urban districts and improving quality of life, making Ontario cities more attractive to talent and investment globally. Faced with intense pressures to protect the environment and reign in sprawl, but also promote the growth and competitiveness of Ontario municipalities, smart growth, as it was 'made in Ontario', provided the Province a unique and imminently strategic opportunity to address, at once, these seemingly contradictory demands.

As part of the implementation of this new provincial agenda, the Province established a Smart Growth Secretariat to manage and coordinate efforts to develop, implement, and 'champion' its 'made-in-Ontario' smart growth reform agenda across the province. Regional multi-stakeholder panels were appointed in five regions across Ontario, to reflect the different 
growth issues that different parts of the province face and to provide a forum for cooperation and coordination on issues that reach across municipal boundaries. The mandate of the panels was to provide advice and support to the Province and municipalities on 'smart growth issues' and in provincial policy and decision-making concerning growth management, infrastructure, resource management and the environment. The panels were also intended to facilitate the integration and coordination of municipal official plans and municipal infrastructure plans across municipal boundaries; identify improvements to planning, delivery and integration of regional services such as transit, water and sewer, and solid waste disposal; and, promote the better use of existing infrastructure and services across the region. Finally, it was expected that the panels would be responsible to develop region-wide and integrated Smart Growth management plans that include, among other things, 'a long-term vision for economic growth'; strategies to improve quality of life by integrating community health, community services, culture and recreation, green space and recreation; protection of significant natural systems; regional integrated transportation strategies (e.g. highways, roads, bridges, transit and other modes of transportation) that create choice, reduce gridlock, and improve access in more remote areas; improvements to the planning, delivery and integration of region-wide services and better use of infrastructure; and strategies to increase housing choice, including a plan to promote more affordable housing each having clear benchmarks and performance measures (Government of Ontario, 2001, p.6).

The Eastern regional 'smart growth' panel, which covered much of eastern Ontario, extending from Prince Edward County in the west, north past Bancroft to Deep River and east past Cornwall to the Quebec boundary, included the cities of Belleville, Kingston, Brockville, Ottawa, Cornwall and Pembroke. Perhaps unsurprisingly, the panel was composed largely of municipal officials (mayors and councillors), real estate developers, and industry representatives 
from Eastern Ontario region. In its report to the Province, the panel expressed a long-term smart growth vision for Eastern Ontario in this way:

In 2035 , eastern Ontario will be a dynamic and prosperous place to live, work and play in harmony with the natural environment. The region's vibrant rural and urban communities, steeped in tradition and rich in history, will continue to attract people seeking a balanced, high quality of life. Growth of the region's communities will respect and incorporate the area's natural assets, ensuring a positive legacy for future generations. Eastern Ontario will be known for its thriving social and cultural assets and highly skilled workforce combined with a strong and diverse economy. People of all ages will have choices in exciting work and economic opportunities as the region's economy continues to be fuelled by its world-class educational institutions, leading-edge technology industries, agricultural assets, manufacturing and natural resources, in conjunction with first-class infrastructure and transportation (Eastern Ontario Smart Growth Panel, 2003, p.3, emphasis added).

Following the Province's lead, the panel's report emphasized the importance of securing and sustaining the economic competitiveness of the region's large urban centres and growing towns and villages, while stressing that future urbanization and economic growth be in 'harmony' with nature - a defining feature of the discourse and politics ecological modernization. The report took the position that retaining and attracting new industry clusters, like the high tech and biosciences clusters in Ottawa, and promoting the region's vibrant tourist industry, are key to building future economic opportunity and prosperity in the region, requiring coordinated planning and infrastructure investment by municipal and provincial levels of government. The panel stressed the importance of prioritizing compact and transit-oriented land-use planning in local and upper-tier official plans in combination with long-term investments in transit infrastructure and user incentives that will enhance the availability, ridership and affordability of public transit choices within and between communities. Although the need for more highways was also emphasized, the panel argued that multi-modal transportation options should also be incorporated in future highway construction and at other appropriate locations. Notably, the 
protection of the region's 'unique natural heritage' was highlighted, though primarily for its value as an 'asset' to the region's tourist economy and as a recreational and lifestyle amenity that gives municipalities a competitive advantage in terms of quality of life, attracting industry and skilled workers to urban centres in eastern Ontario - highlighting the ways in which ideas of 'nature' and 'environment' have become increasing neoliberalized under capitalism (Heynen et al. 2007).

Concurrent with the panels' regional deliberations, the Province initiated its five-year review of Ontario's Provincial Policy Statement (PPS) in 2001, as required under the Planning Act. Given the Harris-Eves government's proclaimed commitment to curbing sprawl and promoting more compact, mixed use, and transit-oriented land use and development planning in keeping with the principles and practices of 'smart growth', the expectation at the time was that the Province would pursue substantive planning reform as part of the PPS review and that these efforts would be coordinated with the Province's smart growth initiative. When it was first announced, the Province indicated that the review would help the government determine whether Ontario's land use planning policies were consistent with smart growth. Diverse stakeholders pressed the Province to reinstate the comprehensive planning reforms, passed by the previous Rae government in 1995 and repealed by the Harris government a year later. A 2001 report by the Regional Planning Commissioners of Ontario, for example, stressed the importance of planning reform that would hold firm current urban boundaries surrounding Ontario cities and to establish minimum residential and employment densities within these boundaries. To enhance the 'livability' of Ontario's urban regions, it stressed the need for policies promoting the development of compact, mixed use 'nodes' that provide employment, cultural and recreational opportunities all in the same place and are accessible, and well connected, by high quality and 
affordable public transit service. It recommended changes to Development Charges policies to require that development bears the full costs for the provision of infrastructure and services including public transit. It also, and quite crucially, called on the Province to work with the federal government to changes taxation policies to stimulate the provision of affordable rental housing, given the critical importance of affordable housing to 'livable' and 'sustainable' cities. Echoing the calls of environmentalists and other stakeholders, the report also stressed the need for policy protecting natural features, including those in and around Ontario's urban regions, not only because they provide green and open space for urban residents, but because they maintain natural habitats and serve important ecological purposes, and called on the Province to work with other levels of government to explore and develop incentives to support and sustain local agriculture in and around Ontario cities and towns. Finally, and not unexpectedly, to ensure that any new 'smart growth' reforms coming out of the PPS review were enforceable, many lobbied aggressively to have the requirement that all planning and decision-making in Ontario 'be consistent with' provincial policy reintroduced. Yet, as the PPS review process unfolded, there was little if any connection between it and the activities and processes organized as part of the Ontario smart growth initiative. Despite the Province's feigned commitment to curbing sprawl, in fact, no changes were made to the Provincial Policy Statement as a result of the review in support of 'smart growth'. In place of substantive planning reform to address the challenges of low-density suburban growth in Ontario, the Harris-Eves government pursued a piecemeal reform and investment strategy that, while deploying the rhetoric of urban environmental 'sustainability', did little to challenge and rework the existing growth regime Ontario.

The defining, and perhaps most dubious, feature of the Harris-Eves government's 'smart growth' agenda concerned investment in infrastructure. Often touted as the 'centerpiece' of the 
strategy, the Province made a commitment to invest in Ontario's 'integrated transportation infrastructure' in an effort to overcome traffic gridlock and improve air quality, particularly in the province's large metropolitan centres like the Greater Toronto area and Ottawa's national capital region. To that end, the Ontario government engaged in a five-year $\$ 20$ billion strategic infrastructure investment program, through its 'SuperBuild Growth Fund', established in 1999. The Superbuild Fund was allocated to a variety of provincial and municipal infrastructure projects, although the corporation's emphasis was the expansion of the province's highway network. In 2001, the Superbuild Corporation's mandate was expanded to include new investments in public transit infrastructure. The Ontario government committed $\$ 3.25$ billion to public transit across the province, over a ten-year period, an investment justified on the grounds that 'strong public transit systems are critical to tackling gridlock and the air pollution it causes' (Government of Ontario, 2002, p.3). At the same time, the Province argued that it was 'equally important to invest strategically in highways - to move goods more efficiently', and with this committed to an investment of $\$ 10$ billion over the same 10 year period, to renew and expand Ontario's highways system (ibid). While new money for Ontario's public transit infrastructure was no doubt welcomed by municipalities, planners, environmentalists and public at large, it paled in relation to the Superbuild corporation's investment in new highway construction. In the 2001/02 Ontario budget, for example, Superbuild investments in highways totaled $\$ 906$ million while investment in public transit amounted to $\$ 50$ million (Winfield 2006, p.43). The Superbuild program, presented as one of the key elements of Ontario's smart growth strategy, in the Pembina Institute's estimation, 'constitute[s] the most ambitious program of highway expansion in the province in more than thirty years ... literally cement[ing] into place decisions that commit Ontario to low-density, automobile and road-dependent development patterns for the 
foreseeable future' (ibid, p.8), and revealing the partial, and at times contradictory, character of Harris government's 'smart growth' regime.

Under the umbrella of the Made-in-Ontario smart growth initiative, the provincial government also passed two pieces of legislation designed to move Ontario forward in realizing its smart growth vision. The first was the Oak Ridges Moraine Act, passed by the Ontario legislature in May 2001, in response to intense public opposition concerning the ecological consequence of low-density suburban expansion in the area of the moraine. The Act established a temporary moratorium on all new development requiring official plan, zoning bylaw or subdivision approval while a land use plan for the moraine could be developed in consultation with environmental groups, developers, farmers, and the more than two dozen municipalities in the region. The outcome of this process, argued the Province, was 'a plan that protects the natural environment while mapping out those areas where new houses and businesses can be safely located' (Province of Ontario, 2002, p.3). Although the Act served to protect the most fragile parts of the moraine from development, the intent of the legislation appeared to have more to do with quieting public dissent concerning sprawl in the region, all the while pursuing a 'plan' that would sanction new housing development on other parts of the moraine (Winfield, 2003, p.15). The legislation was also widely criticized as it dealt only with the situation on the moraine on a 'stand-alone' basis, rather than as part of a more comprehensive approach to urban development and land use planning at a regional scale. In the absence of planning reform restricting low- density suburban expansion across Southern Ontario, it was argued that the Oak Ridges Moraine Act had the effect of simply 'transferring urban development onto other ecologically sensitive areas, rather than reducing suburban expansion as a whole' (ibid). More broadly, environmental lobbyists argued that legislation protecting (parts of) the moraine from 
development, while laudable, was no substitute for comprehensive land use reform in support of compact, mixed-use urban growth and development province-wide.

The second piece of legislation adopted under the umbrella of Ontario's smart growth strategy was Bill 56, the Brownfields Statute Law Amendment Act, also in 2001. The purpose of the Act was to support and encourage the remediation and redevelopment of urban brownfields that have, historically, remained abandoned, idle or underused in Ontario's municipalities given the technical complexities and financial and liability risks that act as barriers to brownfield redevelopment. The Act sets out clear rules for the cleanup of contaminated brownfield sites to ensure that proscribed environmental standards are met and that public health is protected. To reduce the financial risks associated with remediation that have, in the past, made it unattractive to the development industry and other parties, the Act included provisions providing liability protection for municipalities, lenders, owners and developers involved with brownfield properties. At the same time, it sought to streamline planning processes in order to expedite brownfield projects and assist municipalities in providing financial support for remediation costs.

Reflecting the shifting terrain of urban policy at the federal level, the rationale in support of brownfields legislation centered largely on the potential for brownfield remediation and redevelopment to enhance the competitiveness of Ontario cities. When first announced in the Ontario legislature in May 2001, Chris Hodgson, then Minister of Municipal Affairs and Housing, argued that the redevelopment of brownfield sites ensures the efficient use of urban land, and because they are often located in a downtown city cores, their redevelopment would advance the government's smart growth agenda by encouraging the efficient and effective use of existing water and sewer and transportation infrastructure. But more than this, the remediation of brownfields promised to stimulate the redevelopment and 'revitalization' of the downtown 
urban districts in Ontario cities that, over the last several decades, have become largely abandoned in favour of residential and business locations in the expanding suburbs. Beyond opening up new spaces for reinvestment and redevelopment, remediation creates opportunities for municipalities to promote downtown spaces as clean and attractive - as places to 'live, work and play' - in an effort to entice new business investment and residents back to the city. As Hodgson explains:

"As they are cleaned and redeveloped, and people once again live and work in and energize these areas, there can be enormous social and economic gains to the community.

Redeveloping brownfields means cleaning up contaminated lands for our own benefit and the benefit of future generations. As municipalities and developers and investors increasingly realize their [economic] potential, cleaning up and redeveloping brownfields can also preserve our vital green spaces and farmlands for all the people of this province.

By bringing these old industrial and commercial sites back to life, communities have a unique chance to improve their quality of life, protect the environment and attract new business and jobs' (Legislative Assembly of Ontario, Bill 56 Hansard Debate, May 17, 2001).

Although the Province identified the potential value of brownfield remediation and development to alleviate development pressures on agricultural land and other 'vital green spaces' around Ontario cities, the legislation appears to form part of an entrepreneurial urban strategy to reduce barriers to, and create new opportunities for, redevelopment that optimize the use of existing infrastructure while, at the same time, contribute to the physical and economic revitalization of Ontario cities, particularly their downtown centres, in an bid to attract new investment and stimulate growth.

Without diminishing the merit of Ontario's brownfields legislation and policies geared toward protecting the Oak Ridges Moraine, or suggesting that they necessarily conflict with the 
discourse and practices of 'smart growth', the point here is to draw attention to what While et al. (2004, p.551) refer to as the 'selective incorporation of environmental goals' into the Province's smart growth strategy - goals that enabled the government to (at least appear to) protect especially fragile ecologies from 'sprawl', while simultaneously rolling-out a new urban development strategy that supported the twin goals of efficiency and competitiveness in a new era of neoliberal urbanization in Ontario.

\section{'Strong Communities': The McGuinty government's planning reform agenda}

Following the defeat of the Conservative Eves government in the 2003 provincial election, the incoming Liberal government led by Premier Dalton McGuinty implemented more significant changes to the provincial legislative and policy framework governing land use planning in Ontario, as part of its larger and more comprehensive 'Strong Communities' reform agenda. Having inherited a $\$ 5.6$ billion deficit, due in part to irresponsible tax cuts by the Harris Conservatives since 1995, the McGuinty government took office promising to deliver 'real change' to Ontario cities, but in a decidedly pragmatic tone, insisted that change would be 'incremental', 'affordable' and 'responsible' given the Province's unsustainable financial situation at the time (Government of Ontario 2003).

At the Big City Mayors Summit in September 2004, Premier McGuinty described some of the complex challenges facing Ontario municipalities at the time:

From coast to coast, Canadians want cities that work. They want cities in which they can live, dream and put down roots. They share a desire for clean air and water, greenspace and stress-free commuting. They want livable downtowns, great neighbourhoods, fabulous arts and culture, and ample parks and recreation. They seek quality public transit, affordable and decent housing, social diversity and civic tolerance. They want great public schools, colleges and universities, accessible health care and plenty of economic opportunity. And they expect 
governments at all levels to work together to provide reliable local public services. ...

Now, the vast majority of us call the city home. We are an urban people. And we know that the most innovative and thriving economies are found in cities where there is a rich diversity of people, skills and knowledge. The result is that our cities are driving our economy -- and they are doing so in competition with a continent of worthy rivals. For the first time in our history, our cities are firmly in the economic driver's seat. And Canada, and the provinces, will only do well if our big cities are doing well. Our government came to office firmly conscious of this new dynamic. Our commitment to build strong communities tapped into our people's desire to ensure Ontario's cities have everything they need to compete. And it reflects a growing desire among our people for an improved urban experience. Over the last 10 years, Ontarians watched their cities grow with a mixture of fascination and concern. With growth has come gridlock. With rising property values came urban sprawl. With more housing starts came a lack of affordable housing and a need for infrastructure. Ontarians decided they want growth, but not sprawl. The kind of growth that respects the environment, preserves greenspace, builds on what we have, attracts new investment, spreads prosperity and improves quality of life. No level of government can deliver everything on that list. And none of us can even start to tackle that list on our own. That's what our mature new partnership with municipalities is all about. It recognizes that only by working together can we make our cities even greater places to live, work and enjoy (McGuinty 2004, p. 1-3).

In the first decade of the $21^{\text {st }}$ century, the challenges facing cities were at once political and economic, ecological and social, and thoroughly multi-scalar in nature, suggesting the need for comprehensive and coordinated urban policy and governance reform. But what kind of reform, what makes for strong communities?

Rehearsing the now-pervasive logic of urban neoliberalization, it was the position of the McGuinty government that Ontario cities, if they are to be 'strong' and to compete successfully on a global stage and fulfill their role as 'drivers' of the new economy, must be able to attract the kinds of 'people, skills and knowledge', and new investment and industry, on which the most innovative and economically successful cities of the world now thrive. In keeping with this logic, Ontario cities needed to become (if they were not already) 'vibrant' and 'livable' places that are 
rich in cultural, recreational and 'natural' amenities, offer high quality public transit and affordable housing, and are socially diverse and inclusive. This, it was argued, would demand new partnerships among all levels of government to address the crisis of municipal finances, the result of more than a decade of provincial-municipal restructuring and retrenchment, and ensure that municipalities have the necessary resources to invest in and maintain public infrastructure and services. On the planning side, 'strong communities' demanded an approach to growth that enhances environmental quality, preserves greenspaces, makes efficient use of infrastructure and services, attracts new investment and talent, and improves quality of life in Ontario cities.

\section{A 'New Deal for Cities' in Ontario}

When the McGuinty government took office in 2003, the future of Canadian cities was at the centre of public policy debate at all levels of government. If they were to fulfill their roles as the drivers of economic growth and competitiveness in the new economy, municipalities required new long-term commitments by upper levels of government to invest in public infrastructure and services and address the now-persistent fiscal imbalances facing most Canadian cities, after more than a decade of disinvestment.

Building on the efforts of the former Chrétien government and the policy directions established by the Prime Minister's Caucus Task Force on Urban Issues, Prime Minister Paul Martin came to power in 2004 promising a 'New Deal for Canadian Cities and Communities'. Responding to intense pressure by Canada's Big City Mayors Caucus (2006) and the Federation of Canadian Municipalities (2006a) to address the fiscal imbalance facing most Canadian municipalities, the Martin government's new deal included a renewed federal commitment, in partnership with the provinces and territories, to finance the rehabilitation and modernization of 
municipal infrastructure in Canada as well as a promise to explore opportunities to expand the revenue base of municipalities. To deliver on the government's promise of a 'new deal', the 2004 federal budget included a Goods and Services Tax (GST) rebate, anticipated to provide municipalities with $\$ 7$ billion over ten years. Budget 2005 included a commitment to long-term, stable and predictable funding to Canadian cities in the form of gas tax revenue sharing distributed to municipalities through the provinces; a commitment to renew federal funding for strategic infrastructure programs, as well as a promise to double funding for the Green Municipal Funds, administered by the Federation of Canadian Municipalities to provide grants, low-interest loans, and innovative financing to increase investment in infrastructure that enhances the quality, livability and sustainability of Canadian cities (Government of Canada 2005a). Under the Gas Tax Fund, a key component of the Building Canada Infrastructure Plan, the federal government committed $\$ 11$ billion to Canada's provinces and territories over the period of 2005-2014, with $\$ 1.8$ billion dedicated to Ontario municipalities (Government of Canada, 2005b). On the advise of the Prime Minister's External Advisory Committee for Cities (2006) and Communities and the NRTEE (2003), new federal investment was to support 'sustainable' municipal infrastructure development in an effort to improve quality of life, environmental sustainability and urban competitiveness - policy goals that are now seen to be highly interdependent and mutually reinforcing. New gas tax agreements, for example, require that funding be dedicated to the development of public transit, green energy, and other sustainable infrastructure which contributes to cleaner air and water and reduces greenhouse has emissions in Canadian municipalities. As part of these agreements, municipalities are expected to develop Integrated Community Sustainability Plans (ICSPs) to ensure that infrastructure planning is long-term, cost 
effective, and community driven and 'fosters vibrant, creative, prosperous and sustainable cities and communities across Canada' (Government of Canada 2005b, p.2).

In partnership with the federal government, the provincial McGuinty government also took steps to renew Ontario's commitment to municipal infrastructure and service delivery. In its 2004 budget, the Province of Ontario dedicated one cent per litre of the provincial gasoline tax to municipal infrastructure, to support the development and expansion of public transit services in Ontario municipalities, a commitment which increased to 1.5 cents per litre in 2005 and two cents per litre in 2006 (Winfield 2006, p.46). In 2005, the McGuinty government also launched ReNew Ontario, a five-year infrastructure plan to direct infrastructure investment to priority areas - including transportation, healthcare, education and affordable housing - in Ontario municipalities. Under the ReNew Ontario plan, the Province committed $\$ 3.1$ billion in direct provincial transit funding between 2005 and 2010 in addition to the new gas tax revenue dedication (Government of Ontario 2005c, p.8).

Since 2005, both the Canadian and Ontario governments have also promised to reinvest in affordable housing. Since the withdrawal of federal government support for housing and social spending in the 1980s and 1990s, which led to multi-billion dollar federal surpluses, little has been reinvested in new affordable homes in Canada. In fact, over the last decade, less than one percent of all new homes built in Canada were truly affordable to low income households (Shapcott 2007, p.3). By 2007, the affordable housing situation in Canada had become so acute that United Nations Special Rapporteur on the Right to Adequate Housing, Miloon Kothari, following a review of Canada's compliance with international housing laws, declared housing and homelessness a 'national emergency' in Canada (ibid). 
Ontario's affordable housing crisis is particularly severe. Since the mid-1990s, when the Province offloaded much of the costs of social housing to municipalities, investment in new affordable housing, and the repair of existing housing stock, had dwindled to record low levels. As a direct result, housing affordability in Ontario municipalities has been severely eroded. According to the Michael Shapcott of the Wellesley Institute:

Ontario continues to set a series of dubious records when it comes to housing. Ontario has the highest shelter costs (a combination of rent or ownership costs, plus utilities) in the country. The number of Ontario households spending $30 \%$ or more of their income on housing (the danger line used by housing experts) has grown from $25.3 \%$ in 2001 to $27.7 \%$ in 2006 . Median annual shelter costs jumped by $18.3 \%$ from 2001 to 2006 , much faster than the $12.8 \%$ growth in median annual household income and well above the $11.26 \%$ growth in inflation in those years (Shapcott 2008, p.2).

Under the 2005 Canada-Ontario Affordable Housing Program, the ReNew Ontario plan committed to new funding for affordable housing in Ontario. As part of this new federalprovincial agreement, the Province and the Canadian federal government each committed $\$ 301$ million to create 20,000 new affordable housing units, including 5,000 housing allowances for low-income households in Ontario between 2005-1010 (Government of Ontario 2006a, p.13). Although this new funding commitment was generally well received by affordable housing advocates in Ontario, it is modest when compared against the 122,426 active households registered on municipal waiting lists in Ontario in 2006 (ONPHA 2006, p.3). In 2009, municipal waiting lists had climbed to 129,253 and by the beginning of 2010 this number had reached 141,635 - an increase of almost ten percent in just one year (ONPHA 2010, p.4).

In 2006, the McGuinty government initiated the Provincial-Municipal Fiscal and Service Delivery Review to examine the delivery of housing, health and social services and infrastructure funding in Ontario municipalities. To begin to redress the serious fiscal imbalances that 
accompanied the downloading of provincial responsibilities for infrastructure and service provision to municipalities in Ontario in the second half of the 1990 s, the 2006 provincial budget included commitments to increase the provincial share of funding for public health to 65 percent in 2006 and 75 percent in 2007 as well as a commitment to work towards a $50-50$ provincialmunicipal cost sharing arrangement for land ambulance services (Winfield, 2006, p.32). In 2007, the Province announced the 'upload' of the Ontario Drug Benefit program and the Ontario Disability Support Program (ODSP) (responsibilities downloaded to municipalities by the Harris government in 1998) to be fully phased-in by 2011 (ibid). The report of the ProvincialMunicipal Fiscal and Service Delivery Review, released in 2008, included an announcement that the Province would also upload Ontario Works income support payments and employment services administration costs, beginning in 2010 (Government of Ontario, 2008a). However, as of 2010 , there had been no discussion about the possible upload of social housing costs back to the Province.

The Province also committed to creating Ontario's first Long Term Affordable Housing Strategy by 2009 . Housing and social service providers across Ontario saw this as an opportunity to secure long-term financial commitments from the Province to construct new affordable housing and renovate existing housing stock, enabling municipalities to more adequately address the challenges of homelessness, high housing costs and housing insecurity, as well as housingrelated poverty in Ontario cities. As part of the consultation process for the new long-term affordable housing strategy, the Housing Network of Ontario (HNO), a provincial network of affordable housing advocates, issued ' 5 tests' against which the proposed strategy would assessed (HNO, 2008). The first was the requirement that the Province set 'bold targets' to ensure an adequate supply of quality affordable housing for Ontarians supported by sustained, 
multi-year financial commitments. As part of the proposed strategy, the HNO called on the McGuinty government to commit to funding a housing program that creates a minimum of 10,000 universally accessible affordable non-profit and co-op developed housing units annually for the ten years of the strategy; provide funding so that at least fifty percent of these units can provide 'rent-geared-to-income' assistance; and create an annualized fund to repair and maintain existing and new affordable units in Ontario municipalities (ibid, p.2). The second 'test' was that it provide effective mechanisms to assess the scale of housing insecurity and homeless in Ontario and to monitor and measure the strategy's progress in terms of reducing the number of households on wait lists for affordable housing and reducing the number of households that spend 30 percent or more of their income on housing, in all regions of Ontario. The third test concerned accountability of the strategy to the people it intends to serve through, for example, annual public reporting, on-going public consultation over the strategy's lifespan, improving coordination of housing and related programs between Ministries, and improved local control of program design and delivery to suit local needs. Forth, the strategy would be expected to improve accessibility to affordable housing by, for example, introducing a Universal Housing Benefit for low income Ontarians to close the gap between low incomes and high housing costs; expanding the priority list for social housing to include Aboriginal people, communities of colour, people with disabilities and mental health issues, lone mothers, and others facing discrimination by landlords; and, to improve funding for new supportive housing and support services for people with disabilities, mental health issues and addictions to maintain their housing. The fifth and final test concerned key reforms to legislation governing municipal planning, social housing, and the private rental housing market, needed to ensure the adequate provision of affordable housing. As part of the proposed long-term strategy, the HNO called on 
the Province to overhaul the Social Housing Reform Act to improve local service delivery, amend the Residential Tenancies Act to better protect the rights of tenants and ensure landlords cannot raise rents on vacant units beyond rent regulation guidelines, and amend Ontario's Planning Act to allow municipalities to introduce inclusionary housing policies to create new affordable housing through the private housing market (ibid, p.3)

In the autumn of 2010, the Province released its much-anticipated Long-Term Affordable Housing Strategy. Yet, to the disappointment of many in the affordable housing and planning sectors, the new strategy failed to meet the five basic tests set out by the HNO. The strategy proposes some new legislation and administrative procedures that are useful and important, including the consolidation of existing housing and homelessness programs, measures to simplify some administrative aspects of the rent geared to income housing system, and perhaps most notably, a decision to scrap the administratively burdensome Social Housing Reform Act of 2001. Yet, 'the essential items for a long-term affordable housing plan - targets, timeline, and most of all funding over a multi-year period - are missing' from the strategy, as are important legislative changes, including stronger tenant protection laws and inclusionary housing policies to allow municipalities to require a percentage of all new developments to be set aside for affordable housing (HNO 2010). In 2010, the HNO reported that 141,635 Ontario households were on the waiting list for affordable housing, every five tenant households in Ontario pays over 50 percent of their income on rent, and 626,255 households in Ontario are unable to find acceptable housing that costs thirty percent or less of their income (ibid). According to the Wellesley Institute, this situation demands 'a comprehensive, well-coordinated and fully-funded provincial housing strategy that offers a full range of tools to municipalities' that is linked to, and supported by, a national housing strategy in Canada, which the federal government is yet to 
deliver since the dismantling of federal housing programs beginning in 1980s (Shapcott 2008, p.2).

Since 2005, the Canadian government has promised to 'accelerate work' on the development of a national housing strategy (Shapcott 2007, p.3). Little was accomplished until early 2009, when Bill C-304, new legislation promising to deliver a National Housing Strategy that will bring all levels of government together to enact a plan to increase safe, affordable housing across Canada, was introduced. Although not yet passed, the most recent version of Bill C-304 contains a strong commitment to the right to adequate housing and key amendments which include targets and timelines for the elimination of homelessness, provision of financial assistance to those who cannot otherwise afford adequate housing, priority for groups most vulnerable to homelessness and discrimination or for those at risk of violence, and recognition of different needs of people with disabilities and families with children. It also includes measures to ensure the independent review and addressing of complaints about possible violations of the right to adequate housing and review and follow-up on any concerns or recommendations from United Nations human rights bodies with respect to the right to adequate housing in Canada.

In terms of expanding the revenue base of local government, few gains have been made beyond the gasoline tax revenue dedication. In 2006, the City of Toronto Act expanded municipal taxation powers, enabling the City to impose direct taxes on sales of tobacco, alcohol and entertainment and other items. These new taxation powers, however, have been modest at best and have not been expanded to other municipalities in Ontario. 


\section{Planning for 'Strong Communities'}

Together with new federal-provincial commitments to invest in municipal infrastructure and services, the Province of Ontario initiated a series of coordinated land use planning reform experiments to promote more compact, mixed-used, and transit-oriented urban development patterns in Ontario municipalities. From the perspective of the Province, compact urban development had the potential to improve the efficiency and cost-effectiveness of new federalprovincial spending on urban infrastructure while, at the same time, enhancing the 'livability' and competitive potential of Ontario's cities.

In advance of a comprehensive review of Ontario's Provincial Policy Statement, the first step in the McGuinty government's reform strategy was the passing of the Strong Communities (Planning Amendment) Act (Bill 26) in November 2004. To ensure that new planning reforms, introduced by the Province, were enforceable under the Planning Act, the new legislation reintroduced the requirement that planning decisions made by municipal councils, the Ontario Municipal Board and other municipal and provincial planning authorities 'be consistent with' provincial policy. In addition to this, Bill 26 also sought to strengthen the ability of municipalities to control the planning process (vis-à-vis the development industry), removing the automatic right of appeal to the $\mathrm{OMB}$ concerning applications to amend official plans or zoning bylaws for urban settlement area boundary alterations or to establish a new urban settlement area not supported by municipal councils. Amendments intended to improve public participation in municipal planning processes, by increasing the time available to municipal councils for review and public consultation on planning applications (including official plans/amendments, zoning bylaws, holding bylaws, and plans of subdivision/condominiums), were also enacted as part of this new legislation. 
Shortly after the passing of Bill 26, in March 2005, the Province issued a new Provincial Policy Statement for Ontario and launched the Places to Grow ${ }^{2}$ initiative to develop regional growth plans to guide government investments and policymaking. Similar to policy statements adopted by the Rae government as part of the CPDR's New Planning for Ontario reform process more than a decade earlier, the new PPS constitutes an effort on the part of the Province to implement substantive smart growth-inspired planning reform in an effort to promote more 'sustainable' land use and development patterns in Ontario municipalities. The centerpiece of the new policy statement is a clear commitment to manage growth in a way that promotes efficient and cost-effective urban development, by directing growth to areas where infrastructure and services already exist, and mitigates the problematic externalities - the environmental, social and health costs - associated with traditional patterns of low density suburban expansion:

The Provincial Policy Statement focuses growth within settlement areas and away from significant or sensitive resources and areas which may pose a risk to public health and safety. It recognizes the wise management of development may involve directing, promoting or sustaining growth. Land use must be carefully managed to accommodate appropriate development to meet the full range of current and future needs, while achieving efficient development patterns.

Efficient development patterns optimize the use of land, resources and public investment in infrastructure and public service facilities. These land use patterns promote a mix of housing, employment, parks and open spaces, and transportation

\footnotetext{
${ }^{2}$ The Places to Grow initiative, to date, has focused on the development of a growth plan for the Greater Golden Horseshoe (GGH) region, including and extending beyond the Greater Toronto Area in Southern Ontario, where the pace, scale and consequences of low-density suburbanization have been most acute in Ontario. A key feature of the growth plan for the GGH region was the establishment of a greenbelt protecting 760,000 hectares of land (natural heritage, prime agricultural, and rural countryside) from future urbanization. The intention of the plan has been to stop sprawl by directing future residential and employment growth to designated locations in GHG region. Consistent with the PPS, the intention of the plan has been to stop sprawl in the GGH region by directing future residential and employment growth to existing built-up areas and to designated growth areas and encouraging a shift towards more compact, mixed-use and transit-oriented development patterns, optimizing use of existing infrastructure and services while also reducing development pressures on the region's agricultural land and natural heritage features (Government of Ontario 2006b).
} 
choices that facilitate pedestrian mobility and other modes of travel. They support the financial well-being of the Province and municipalities over the long term, and minimize the undesirable effects of development, including impacts on air, water and other resources. Strong, livable and healthy communities enhance social well-being and are economically and environmentally sound (Government of Ontario 2005a, p.2).

Beyond the efficient use of infrastructure and services, however, the Province also viewed compact urban development as a strategic opportunity to enhance the 'livability' and economic competitiveness Ontario's cities. In a 2005 report entitled Municipal Quality of Life for Economic Prosperity, released within weeks of the new PPS, the Province describes the link between quality of life and economic competitiveness and the potential for compact development to revitalize existing residential and commercial districts and preserve the historic, cultural and natural amenities and environments that make Ontario's cities more attractive places to 'live, work and play':

Business leaders around the world recognize that quality of life is a key component for economic prosperity. A municipality can capitalize on this knowledge by establishing a clear community vision and specific community goals that build local quality of life.

What is quality of life and how does it affect economic prosperity? Quality of life can best be described as the degree to which people have a sense of well-being in relation to the space in which they live, work and play. Generally, communities that are safe, attractive, environmentally sound, diverse and culturally rich are not only desirable places to live, but tend to thrive economically.

Building on a sense of place and enhancing quality of life can be done in many ways. Some examples include strengthening community assets through revitalization and rehabilitation of commercial or residential areas, returning former industrial lands to productive uses, historic building conservation or taking a leadership role in the arts and culture sectors. By investing in the preservation and enhancement of natural, social, cultural and physical features, municipalities can distinguish themselves and add to their uniqueness (Province of Ontario 2005b, p.4). 
Compact urban development, in other words, satisfied the requirements of efficient and costeffective growth, allowing municipalities to rationalize new spending on infrastructure and to keep property taxes down, while at the same time creating new opportunities to reinvest in the revitalization of downtown and other high value urban districts and the preservation and enhancement of cultural and recreational amenities, including greenspaces and other natural features, that make Ontario cities 'unique' and attractive to skilled professionals and investment.

As part of this new planning regime, under the 2005 PPS, municipalities are required to establish firm urban growth/settlement boundaries and direct new development to existing urbanized areas. In defining growth boundaries, municipalities are required to ensure sufficient land is made available to accommodate housing, employment and other land uses to meet projected needs for a time horizon of up to twenty years, with a minimum requirement of a tenyear supply and three year supply of serviced land at all times.

In existing built-up areas, the new PPS requires that Ontario municipalities promote compact, mixed-use and transit-supportive development in their official plans and in all land use and development decisions. This is to be achieved through a strategy of intensification, which the Province defines as 'the redevelopment of a property, site or area at a higher density than currently exists within a defined existing built-up area' (Government of Ontario 2005a, p.32). The development of vacant and/or underutilized lots within developed areas, infill development, the expansion or conversion of existing buildings within an existing built-up area, and the remediation and redevelopment of urban brownfield sites all qualify as 'intensification' under the policy statement. In their official plans, municipalities are now expected to establish and implement 'minimum targets' for intensification within existing built-up areas as well as phasing policies to ensure that specified intensification targets are achieved prior to, or concurrent with, 
new 'greenfield' development within 'designated growth areas' inside settlement boundaries. Under the PPS, new development taking place in designated growth areas should occur adjacent to the existing built-up area and have a compact form, mix of.uses and densities that allow for the efficient use of land, infrastructure and services, though this is not a mandatory provision.

In terms of environmental protection, the policy statement contains important new provisions concerning the protection of prime agricultural land and provincially significant woodlands, wetlands, and wildlife habitat from unnecessary development and expands provisions regarding source water protection in Ontario municipalities. While clearly a step forward, environmental protection policies under the new PPS remain limited in several respects. The PPS policies concerning the protection of agricultural land, for example, give highest priority to specialty croplands (including, for example, lands the Niagara Region dedicated to tender fruit production), affording more limited protection to other agricultural lands. Under the PPS, development is still permitted on prime agricultural land under particular circumstances, potentially undermining the long-term viability of local and regional food systems in Ontario. For example, although the expansion of urban settlement boundaries may only occur during the comprehensive 5-year review of official plans, the PPS retains a clause concerning requirements for urban land supply. Where municipalities can demonstrate insufficient land supply to meet residential and employment needs over the minimum 10-year (and maximum 20-year) planning horizon, boundary expansions are not only permitted, they are required under the current policy statement. This, of course, has the effect of rendering agricultural land (not dedicated to specialty crops) and other non-urban environments immediately outside settlement boundaries vulnerable to new waves of suburban development. Likewise, provisions protecting provincially significant environments contain exception clauses that permit development in or adjacent to such 
environments where in can be demonstrated that there will be 'no negative impacts on the natural feature and its ecological functions' (Government of Ontario 2005a, p.15). On lands inside settlement areas boundaries, where development opportunities are already constrained, exception clauses are problematic as they create political space for housing developers to make a case for development, potentially leading to protracted battles at the OMB. Woodlands, wetlands and wildlife habitat not designated as 'provincially significant' receive no protection under the current PPS and may, at any time, be subject to development inside settlement boundaries. Given current policies favouring intensification inside settlement boundaries, urban green spaces are likely to be subject to intense development pressures as a result, raising important and timely questions concerning quality of life and the value of urban green spaces in Ontario cities. Taken together, these provisions appear to be geared toward securing the long-term growth prospects of Ontario municipalities and to 'blunt opposition' (Sewell 2009, p. 223) from the development industry, at the expense of more stringent environmental protections.

Although justified first and foremost as a measure to encourage efficient development patterns that optimize the use of urban land, infrastructure and services, avoiding the need for their unjustified or uneconomical expansion beyond a municipality's existing built environment, while protecting agricultural land and other non-urban environments outside settlement areas from unnecessary (or at least premature) urban development, support for intensification in the new policy statement identifies the potential of compact, mixed use development to contribute to more socially equitable and inclusive cities and neighbourhoods. The PPS encourages higher density development and land use patterns characterized by a mix of housing, employment (including commercial, industrial and institutional uses), parks and open spaces as a means to make public transit more feasible (and cost effective) and create neighborhoods that are more 
pedestrian oriented. The current PPS also expresses the fundamental obligation of municipalities in the provision of affordable housing, as an extension of their wider housing obligation. As part of this obligation, municipalities are required 'to provide an appropriate range of housing types and densities' and are directed, more specifically, to provide for housing 'affordable to low and moderate income households' (Government of Ontario 2005a, p.8-9). To that end, municipalities are expected to establish and implement 'minimum targets' for affordable housing, either on their own or in coordination with an upper-tier municipality. However, the current PPS falls considerably short in establishing clear and enforceable policy concerning the provision of affordable housing in Ontario municipalities. Unlike earlier policy statements that set minimum targets for affordable housing which municipalities were expected to meet, the current PPS defers this responsibility to municipalities. Moreover, it also fails to provide any clear policy direction or planning tools to guide and empower municipalities to facilitate affordable housing in new private sector-led residential development. Inclusionary planning, a tool that gives municipalities the power to require developers to set aside a number of units as affordable housing in new housing developments, was given consideration as part of the 2010 review of the PPS, to be discussed shortly.

In 2006, the McGuinty government passed a second set of land use planning reforms to support the implementation of the Province's 'strong communities' planning agenda. The Planning and Conservation Land Statute Law Amendment Act (Bill 51), which came into effect in January of 2007 , contained noteworthy environmental provisions to ensure that municipal 
council and OMB decisions are consistent with current provincial policy ${ }^{3}$. As part of this second wave of reform, the McGuinty government drew particular attention to the need for reform of the Ontario Municipal Board. Concerns regarding the process by which board members were appointed and the role of the board in adjudicating planning disputes were drawing significant public attention at the time. In particular, the qualifications and expertise of board members were being called into question as was the ability, and tendency, of the board to 'substitute its opinions for those of elected municipal councils', suggesting that the OMB appeals process was inherently undemocratic (Government of Ontario 2004, p.8). Historically, the requirement that OMB rulings need only 'have regard to' provincial policy has served to undermine the authority of elected councils in land use planning, often 'requiring municipalities to devote scarce resources to defending decisions that have already been dealt with through the planning process' (ibid). Not surprisingly, the authority of the OMB to over-rule municipal decisions, and the general perception that $\mathrm{OMB}$ rulings tend to side with the interests of the development industry, have given rise to concerns that, in order to avoid often-protracted and costly OMB appeals, municipal decision-making increasingly capitulates to developer interests at the expense of environmentally sound or socially equitable planning. The requirement, under Bill 26 , that $\mathrm{OMB}$ decisions 'be consistent with' the PPS was an important first step in strengthening the authority of municipal

\footnotetext{
${ }^{3}$ The provisions of Bill 51 require that municipal council and OMB decisions be consistent with provincial policies and plans at time that the council or the $\mathrm{OMB}$ takes a decision on a planning matter. Prior to this, the laws and policies in effect at the time a developer files an application with a municipality were the ones that governed municipal decision-making. This new provision was welcomed by a coalition of environmental organizations, including The Sierra Club of Canada, Environmental Defense, the Canadian Environmental Law Association, Ontario Nature and the Pembina Institute who argued that it will prevent a surge of development applications in anticipation of an upcoming change to a more environmentally protective policy, as occurred in some Ontario municipalities just before the 2005 Provincial Policy Statement came into effect. The legislation also sought to ensure that municipal and OMB planning decisions better reflect provincial interests concerning the protection of ecological systems and agricultural resources by providing a mechanism for the provincial Cabinet to intervene in specific cases to protect these interests (CELA, 2006).
} 
decision-making vis-à-vis the $\mathrm{OMB}$ in-so-far as it reduced the of discretion available to the Board in its rulings. Bill 51 amendments further required that the OMB 'have regard to' municipal decisions in its rulings and permitted municipalities to establish their own appellate bodies to hear appeals on minor planning matters. The matter of board appointments was not addressed in the new legislation.

As part of the OMB reforms, long-standing concerns regarding barriers to public participation in the OMB appeals process were also aired. Given the cost of retaining the kinds of legal and planning expertise required to participate effectively in the OMB appeals process, it is widely acknowledged that the lack of intervener funding for community organizations and public interest groups places them at a significant disadvantage vis-à-vis developers and municipalities who have significant financial resources on which to draw in OMB hearings. Unfortunately, a proposal to establish a mechanism for intervener funding for bona fide public interveners was not addressed in the new legislation, leaving them with few resources to participate effectively in Board hearings. Other provisions have the potential to further undermine public participation in the OMB appeals process. Bill 51 removes the right of appeal of official plans, official plan amendments and plans of subdivision to the OMB for persons (other than public bodies) who do not make oral or written submissions during the public consultation phase of municipal decision-making, restricts the rights of such persons from becoming parties to OMB hearings, and prohibits the introduction of new evidence at OMB hearings that was previously unavailable to municipal councils during its initial decision-making concerning an official plan, official plan amendment or plan of subdivision. While these new provisions strengthen the authority of municipal decisions vis-à-vis developer interests in the OMB appeals process, they have also drawn significant criticism given their potential to restrict 
opportunities for public interveners to participate in municipal council and OMB processes and decision-making: 'In some cases, residents do not become aware of a proposal or council decision until they see a notice of passing of a by- law or read about it in their local newspaper. In some circumstances, residents or members of the public may nevertheless have a significant interest in the matter either in their own right or in respect of the impact on their community or the environment' (CELA 2006, p.2).

Finally, and perhaps most significantly, Bill 51 reforms also gave Ontario municipalities new planning and financial tools in support of smart growth intensification in Ontario municipalities. The legislation enhances the flexibility of municipalities to regulate the minimum and maximum density and height of new development in their zoning by-laws. Municipalities have also been granted the authority to establish conditions in the approval of zoning applications, strengthening their powers to address the unique challenges of intensification and redevelopment. In an effort to improve the aesthetics and quality of intensification projects and their acceptance by residents living in neighborhoods undergoing significant intensification and redevelopment, municipalities are now permitted to consider, as part of the development applications review process, the exterior design of new development, including the character, scale and appearance of proposed buildings in relation to the surrounding built environment. Municipalities are also permitted to require that sustainable design features be incorporated into new buildings and subdivision plans. This may include, for example, green roofs and solar panels, the preservation of on-site vegetation and water-conserving landscaping, and requirements that the design, layout and servicing of new subdivisions promote energy conservation and provide pedestrian walkways, bicycle paths and transit ways alongside public roads. 
As part of Community Improvement Plans (CIPs), Bill 51 provisions also give municipalities new planning and financial tools to stimulate intensification and redevelopment in existing built-up areas (such as mainstreets, neighbourhoods, or entire communities) identified as being in need of repair, rehabilitation and revitalization. In the 1970 s and 1980 s, community improvement planning was a popular means to support and encourage 'neighbourhood renewal' and commercial area improvement in Ontario municipalities. By the late 1990s, interest in CIPs, as an instrument of urban revitalization, surged as the links between 'place', quality of life and the economic competitiveness of cities in the 'new economy' fermented in urban policy circles at all levels of government. According to the Province's Ministry of Municipal Affairs and Housing, Ontario municipalities are now using CIPs to encourage residential and commercial intensification and mixed-use, transit and pedestrian oriented development, and/or to encourage development that incorporates sustainable design, such as LEED®, in places undergoing revitalization (Government of Ontario 2008b). To stimulate urban intensification and revitalization in CIP target areas, provisions under Bill 51 permit municipalities to offer financial incentives, in the form of grants or loans, to developers for new residential or commercial development (including the remediation and redevelopment of brownfields), or to existing property owners to add additional building space to an existing building, improve building facades along mainstreets or other public rights-of-way, or improve hard and soft landscaping and signage in an effort to enhance the quality of these urban places and their larger urban regions.

Concerning housing, Bill 51 also reintroduced municipal powers concerning secondary units in existing dwellings, first passed by the Rae government in the mid-1990s and promptly repealed by the Harris Conservatives in 1996. In their official plans, municipalities are once 
again able to designate areas where second residential units are permitted and, under the new legislation, there is no right to appeal the secondary units designation to the OMB. This is an important provision as it enables (though does not require) municipalities to encourage smallscale intensification and to increase the stock of affordable rental housing, which remains scarce in Ontario cities (ONPHA 2010). Unfortunately, it is one of few reforms to date that links concerns of sustainable urban development with those of social equity and inclusion in the planning process.

\section{A place for equity in sustainability planning?: Inclusionary housing and the 2010 PPS review} At a time when federal and provincial commitments for affordable housing fail to meet the growing demand for affordable units in Ontario municipalities, the affordable housing sector has begun to take a serious look at the Provincial Policy Statement as a tool for municipalities across the province to ensure that all Ontarians have secure access to safe, healthy and affordable housing. In 2010, during the five-year review of the Provincial Policy Statement, housing and planning advocates expressed strong support for the development of explicit policies and legislation that strengthen the PPS's affordable housing mandate. In place of a weak and largely unenforceable statements on housing, the Wellesley Institute recommended, in its submission to the five-year PPS review, that the PPS be revised to include a statement that establishes a clear obligation for all municipalities to use all of their available power and resources in an 'affirmative and pro-active way' in providing affordable housing in their jurisdictions (Blickstead and Shapcott 2010, p.5). 'The PPS must make clear that municipalities have a responsibility to effect the development of affordable housing through the full use of their powers and resources. They cannot solely rely upon the private market, or provincial and federal 
funding, to achieve it' (ibid). To that end, the PPS needs to establish clear and demanding affordable housing targets and establish monitoring procedures that hold municipalities accountable for meeting these targets. Also essential, is a statement under the PPS that defines 'affordable housing' in more precise terms. The language of the 2005 PPS is vague, referring only to 'housing that is affordable to low and moderate-income households'. It is the position of the Wellesley Institute, and other housing advocates in Ontario, that only a definition of affordable housing as 'below-market housing' - that is, 'housing that is provided at a price or rent substantially below that available for the equivalent new housing in each community' - is sufficient to ensure that new ownership and rental housing is truly 'affordable' and provides for the housing needs of the most economically vulnerable (ibid).

Policy and legislative changes to the PPS and Planning Act are also needed to expand the authority of municipalities, and the planning tools available to them, to provide for affordable housing through the private real estate market. Municipalities are currently limited to providing subsidies from property taxes and offering municipal lands at low or no cost, neither of which are attractive nor sustainable for local governments. Another tool presently available to municipalities is 'density bonusing', a planning provision under Section 37 of the Planning Act. Density bonusing allows municipalities to offer developers additional building height or density in exchange for 'community amenities' - which can include, for example, affordable housing, recreational facilities, daycare facilities, park space, or public art - as part of new high density developments. However, with the exception of Toronto, density bonusing, under the provisions of Section 37, has not been widely used, to date, by municipalities to create new affordable housing in their jurisdictions, for a few reasons. The first is that under the Planning Act, Section 37 permits, but does not require, municipalities to offer extra height or density in exchange for 
community benefits such as affordable housing. Municipalities, that have historically granted developers extra height and density without conditions, have been hesitant to make new demands on the development industry in the absence of strong and supportive provincial policy, should the matter be taken to the OMB on appeal. Moreover, under current legislation, density bonusing may be used to obtain a diverse range of community amenities, which may or may not include affordable housing. How, and by whom, 'community benefits' are negotiated and decided under Section 37 agreements remains an open question. Despite this, at a time when municipalities are expected to encourage higher density development in existing urban neighbourhoods, density bonusing offers municipal officials, planners and community organizations a potentially useful tool through which to secure community benefits as part of new development where increases in height or density, above that which is permitted under existing zoning regulations, are sought by developers. New community amenities, such as new affordable housing units, may help to maintain or even enhance neighborhood 'livability' and to mitigate the gentrifying effects that can accompany new high density urban redevelopment and revitalization programs. Otherwise, urban policies encouraging higher density urban development appear only to benefit the profit margins of developers who are now not only permitted, but encouraged, to build higher and at greater density.

There are, however, many other tools that could be made available to municipalities to improve the provision of affordable housing through the private housing market. Development charges specific to affordable housing, tax increment financing, housing trust funds, community land trusts, and funding derived from other locally-based taxes are a few examples (Blickstead and Shapcott 2010, p.6) 
Perhaps the most effective tool to provide for affordable housing through the private housing market is inclusionary housing (also referred to as 'inclusionary planning' or 'inclusionary zoning'). Inclusionary housing is a policy tool that permits municipalities to require a specified percentage of affordable units, at a price or rent below what the market would otherwise provide, be built as part of new housing developments. Costs to developers are typically offset by way of concessions, such as density bonusing in which municipalities grant developers an increase in building height or density in exchange for a percentage of affordable units, to ensure that developers maintain a reasonable return on investment. Unlike the density bonusing provisions of Section 37 under the current Planning Act, inclusionary housing is specifically concerned with ensuring that affordable housing units are built as part of all new developments.

According to the Wellesley Institute (2009), strong inclusionary housing policies mean that affordable housing - and broader concerns of social equity and inclusiveness at an urban and neighbourhood scale - become a normal part of all new private sector-led urban development. Unlike conventional development patterns that often restrict housing options for low and moderate income families, inclusionary housing creates opportunities for affordable rental and home ownership to be integrated into every neighbourhood, and, thereby, a more affordable range of housing across the entire city (ibid). Building affordable housing into all new development creates opportunities for all people (not just those that can afford it) to live near their workplaces, for seniors to 'age in place', and for children to live in the cities and neighbourhoods where they grew up, and as such, constitutes a more socially inclusive approach to neighborhood planning and urban development. In this respect, inclusionary housing has the potential to ensure that the Province's smart growth and intensification policies incorporate 
(rather than ignore, or perhaps even undermine) critical issues of social equity and inclusion in new compact urban development in Ontario municipalities. According to the Regional Planning Commissioners of Ontario (RPCO), support for inclusionary housing allows to Province to realize the goals of compact urban development and affordable housing in ways that are mutually reinforcing (RPCO 2010).

To move forward, the Province must enact legislation that would provide municipalities with the explicit legal authority to adopt inclusionary housing policies and define the rights and responsibilities of developers and builders in contributing to the creation of affordable housing. In 2009, private member's Bill 198 (subsequently Bill 58), An Act to amend the Planning Act with respect to inclusionary housing, was introduced in the Ontario legislature by NDP MPP Cheri DiNovo. The proposed legislation sought to amend the Planning Act to include the adequate provision of a full range housing, including housing that is affordable to low and moderate income households, as a matter of 'provincial interest'. It proposed changes to sections 34 and 37 of the Planning Act to allow municipal councils to pass zoning by-laws requiring inclusionary housing in the municipality and regulating the required percentage of affordable housing units in new residential developments in the municipality. It also contained an amendment to Section 51 of the Act to allow municipal planning authorities to impose as a condition to the approval of a plan of subdivision a requirement that a specified percentage of housing units in all new housing developments in the subdivision be affordable to low and moderate income households. Bill 198 (subsequently Bill 58) was highly regarded in the Ontario legislature (uncommon for private members bills), passing second reading in the Ontario legislature and referred to the Standing Committee on Regulations and Private and Private Bills in June 2010. The RPCO, the HNO, the Ontario Non-Profit Housing Association and the 
Wellesley Institute all strongly support this proposed legislation but argue that it is not sufficiently clear in its present form. To be effective, the RPCO argues, for example, that inclusionary housing legislation requires 'clear and strong language mandating, not encouraging, the provision of inclusionary housing' (RPCO 2010, p.2 emphasis added). Establishing fixed and non-negotiable rules regarding inclusionary housing ensures that municipalities are not able to shirk their affordable housing obligations while also making certain that all developers are treated in a consistent and equitable way (Blickstead and Shapcott 2010). Mandatory inclusionary housing policies, under the Planning Act and PPS, would also strengthen the position of municipalities vis-à-vis developers and reduce the likelihood that agreements are appealed to the OMB. The RPCO argues that this requirement should apply to all municipalities, to ensure that a minimum 'as-of-right' standard is imposed across the Province, guaranteeing that implementation is done in a consistent manner, across municipalities and that the use of such powers would not be appealable to the OMB: 'Municipalities must not be subject to on-going lengthy and costly legal challenges to justify the requirement for affordable housing' (ibid). Unfortunately, the 2011 Ontario election resulted in the dissolution of Bill 198 before it could be adopted by the Ontario legislature. MPP Cheri DiNovo plans to reintroduce the bill to the legislature in the fall session, 2012.

In the absence of clear and enforceable policy, under the PPS and Planning Act, requiring that municipalities build affordable housing into new private sector residential development, the Province's commitment to promote more compact, 'sustainable' and 'livable' patterns of urban growth will continue to obscure issues of equality and redistribution which ought to be, if they are not already, key elements of 'urban sustainability' in municipal planning in Ontario. 


\section{Conclusion}

This chapter traces the emergence of 'smart growth' as a new planning regime in Ontario. According to the Ontario Smart Growth Network, a new coalition of environmental, affordable housing, and community-based organizations from across the province, smart growth promises the creation of more 'sustainable' cities and more livable and inclusive urban neighborhoods through support for more compact, mixed use, transit and pedestrian oriented urban development, offering more affordable and diverse housing options developed in close proximity to employment, public services, shopping, recreation, and natural amenities. In the context of recent planning reform experiments in Ontario, however, the progressive potential of smart growth has been severely undermined by the neoliberal provincial policy landscape in which it has emerged.

The argument developed in this chapter is that smart growth, as a new urban environmental 'fast policy' (Peck 2005) in Ontario, emerged as a tactical response, on the part of the Conservative provincial government, to manage the contradictions and crises of its own neoliberal restructuring and reform measures since 1995. But, more than this, smart growth has become a key feature in the rolling forward of a new, and deeply interventionist, neoliberal agenda geared toward strengthening Ontario's economic competitiveness through a series of environmental and planning policy reforms measures aimed at enhancing the 'sustainability' and 'livability' of its rapidly growing urban regions.

Specifically, the evidence presented in this chapter suggests that the Harris-Eves' smart growth planning reform agenda has been ultimately geared toward ensuring that future new urban development, in municipalities across the province, is as efficient and cost effective as possible, thereby reducing financial pressures on already fiscally-constrained municipalities 
following more than a half decade of provincial-municipal restructuring in Ontario. However, building on recent UPE scholarship (Keil and Desfor 1996; Keil and Graham 1998; Bunce 2004; While et al. 2004; Gibbs and Krueger 2007; Jonas and While 2007; Keil 2007), the chapter goes a step further to argue that this new 'Made-in-Ontario' planning reform process espousing the protection of Ontario's unique urban and regional environments and creation of more 'vibrant', livable', and 'sustainable' urban landscapes has also been mobilized as part of a larger entrepreneurial strategy through which the Province of Ontario has actively sought to strengthen the competitiveness of Ontario cities, making and marketing them as good places to live and invest in the new knowledge economy. In this respect, I argue, smart growth appears suggestive of the kind of 'win-win' discourse that has come to define the politics of ecological modernization (Hajer 1995; Harvey 1996). The goal of this chapter, however, is not simply to draw attention to the ways in which smart growth, and dominant interpretations of urban environmental 'sustainability', have coincided with recent neoliberal policy transformations; rather, it is to suggest that smart growth, as a new environmental governance regime and planning reform experiment, has been constitutive of a new wave of neoliberal urbanization in Ontario.

Without diminishing the importance of securing a place for matters of 'nature', 'environment' and 'sustainability' in provincial and municipal policy and planning debates, this chapter argues that recent planning reform in Ontario appears to eclipse issues of social investment and redistribution central to more progressive interpretations of 'sustainability'. Since the onslaught of political economic restructuring and reform in Ontario in 1995, issues such as poverty, homelessness, and other forms of marginalization and inequality are more important than they have ever been. Yet, where they appear at all in Ontario's policy statements, these 
issues are obscured to the more pressing matters of urban competitiveness and economic growth - hallmarks of contemporary neoliberalization. This matters, I argue, because Ontario's planning system, including recent policy reforms and legislative changes in support of 'smart growth', establish the policy framework and priorities, within which Ontario municipalities, like the City of Ottawa, develop their own official plans and make planning and development decisions that affect the everyday lives - and the everyday lived environments - of people in Ontario's cities. 


\section{Chapter Six}

\section{Smart growth intensification and the 'greening' of urban governance: The City of Ottawa, Canada}

\section{Introduction}

In June 2001, the City of Ottawa, Ontario launched Ottawa 20/20, the largest and most ambitious planning process in the region's history. Anticipating considerable growth and change over the coming twenty years, Ottawa 20/20 involved a two-year planning and public consultation process to produce the first Official Plan for the recently amalgamated city region. Although different from earlier planning efforts in many respects, Ottawa 20/20 marked a turning point in municipal policy with the integration of a new 'sustainability' agenda intended to guide Ottawa's urban policy, planning strategies, and development decisions over the Plan's twenty year time horizon. According to the Official Plan, '[t]he goal of Ottawa 20/20 is sustainable development' (City of Ottawa 2003, p.2). Drawing explicitly on the language of the WCED report (1987), Ottawa 20/20 defines 'sustainable development' as an urban policy and planning framework premised on 'the integration of economic growth, social equity and environmental management' priorities (ibid) - what is, in today's vernacular, referred to as 'the triple bottom line' (Braissoulis 1999).

In line with recent federal policy statements and planning reform experiments in the Province of Ontario, the City of Ottawa's 2003 Official Plan established a new 'smart growth'inspired urban environmental policy agenda and planning framework to curb the problem of lowdensity suburban 'sprawl' through a combination of regional growth management and urban intensification policies. Specifically, the new Plan called for a shift towards more compact, mixed-use urban development patterns as a measure to reduce development pressures on the 
region's agricultural land, open and recreational spaces, and surrounding natural environments; bring greater efficiency and cost effectiveness to municipal infrastructure and service provision; stimulate the physical and economic revitalization of Ottawa's urban core; and, promote a more economically competitive urban region. According to the Plan, smart growth intensification promises to "ensure that growth "works" for Ottawa - that it will serve as the basis for realizing our collective vision of a livable, prosperous and sustainable city' (City of Ottawa 2003, p.1, emphasis added).

Focusing on the 2003 Official Plan, this chapter explores the emergence of 'smart growth' as a new urban environmental policy regime in the City of Ottawa. Building on recent critical theorizing in urban political ecology (UPE) that advances a path-breaking view of urbanization as a complex, dynamic and power-laden process of socioecological change (Swyngedouw and Heynen 2003; Swyngedouw 2004, 2006; Heynen et al. 2006; Keil and Boudreau 2006), this chapter takes as its starting point that the City of Ottawa's new 'smart growth' strategy constitutes a historically and geographically specific policy experiment geared toward transforming the region's socioecological landscape away from conventional patterns of low-density, automobile dependent suburbanization towards the kind of compact, high density, mixed use, transit and pedestrian oriented urban environments that have become virtually synonymous with 'urban sustainability' in Canadian urban policy and communities in recent years. From an UPE perspective, the chapter explores the array of political and economic, social and ecological relations and processes through which the City of Ottawa's broad 'sustainability' agenda and its more specific 'smart growth' urban environmental strategy have been defined in the context of the Official Plan. 
More specifically, this chapter develops the argument that the City's 'sustainability' agenda and smart growth urban environmental strategy appear to constitute an effort to negotiate the complex governance dilemmas associated with the advance of urban neoliberalization, including heightened levels of political economic uncertainty that have accompanied the restructuring and rescaling government responsibilities and the demands of the 'new economy'. As discussed in Chapters 4 and 5, the dismantling of Canada's national welfare state since the late 1980 s, followed by dramatic provincial-municipal restructuring in Ontario from the mid1990s onward, translated into massive cuts in federal and provincial spending and the eventual 'downloading' of key provincial responsibilities for urban infrastructure and services to municipalities by the end of the decade (Graham and Phillips 1998; Keil 2002; Kipfer and Keil 2002; Fischler et al. 2004; Boudreau et al. 2009). As a tactical response, Ontario municipalities have shifted towards more competitive and entrepreneurial styles of governance that privilege urban competitiveness and economic growth as policy goals. Although the triumph of a neoliberal 'growth first' urban development politics might seem at odds with broad notions of urban environmental 'sustainability', recent contributions to the field of UPE draw critical attention to the ways in which urban entrepreneurial strategies appear to depend more and more on the 'selective incorporation of environmental goals' into urban policy, planning and everyday development practices in cities (While et al. 2004, p.551; also see Keil and Graham 1998; Bunce 2004, 2009; Gibbs and Krueger 2007; Jonas and While 2007; Keil 2002, 2007). In cities across much of North America and Europe, for example, the advance of the 'new economy' has involved new forms of urban entrepreneurialism geared toward 'the active remaking of urban environments and ecologies' (While et al. 2004, p.551). Policies promoting the protection and enhancement urban and regional 'natural' environments, investment in new state-of-the-art 
public transit systems, the revitalization and repopulation of city centre spaces, and the remediation of environmentally contaminated, derelict and/or underutilized properties, for example, have become key strategies deployed by local governments to improve the attractiveness, vibrancy and 'livability' of urban environments in order to attract knowledge economy investment and labour and sustain long-term urban competitiveness. In this respect, as Gibbs and Krueger (2007, p.103) observe, '[i]n the spaces of the new economy, economic success, quality of life and the "good environment" are closely intertwined'.

In the current era of political-economic restructuring and governance reform, I argue that the City of Ottawa's 'smart growth' urban environmental policy regime is playing an active role in a new wave of neoliberal capitalist urbanization in the city region. At a time when cities are shouldering new financial burdens beyond their means, officials and planners in the City of Ottawa have championed 'smart growth' as a strategy intended to reduce growth-related municipal spending by directing future urban development to Ottawa's existing built environment where city infrastructure and services are already available. At the same time, intensification policies designed to facilitate new high density, mixed-use urban development are presented as a vehicle to protect Ottawa's regional environments from premature suburban expansion while, simultaneously, stimulating the physical and economic revitalization of Ottawa's downtown and neighbouring urban districts. Without diminishing progress made in securing a place for urban environmental issues in the City's official planning, I argue that the socioecological transformation of the city region envisioned in its smart growth strategy appears ultimately geared toward ensuring Ottawa's long-term economic success in an era of intense intra-urban competition, eclipsing issues of social and environmental justice central to more 
progressive discourses of urban environmental 'sustainability' (Haughton 1999; Gibbs and Krueger 2007; McCann 2007).

\section{Ottawa 20/20 and the City's new 'smart growth' urban environmental policy agenda}

At the beginning of 2001, after nearly five years of neoliberal restructuring and rescaling of responsibilities in Ontario, the Province passed legislation amalgamating the eleven lower tier municipalities that made up the former Regional Municipality of Ottawa-Carleton into a single, and much larger, municipality on the rationale that amalgamation would bring greater efficiency and cost-savings to municipal governance (Sanction 2000). Following amalgamation, the new City of Ottawa was responsible for planning the city region's future growth and development and providing municipal infrastructure and services to a population of about 800,000 people living in a geographically extensive city of roughly 2,760 square kilometers (City of Ottawa 2003, p.i). Just months after amalgamation, in June 2001, the new City of Ottawa launched the Ottawa 20/20 initiative, a two-year planning and public consultation process to develop the City's new Official Plan, creating a vision and policy framework to guide the growth and development of the new city region over a twenty-year planning horizon.

During the Ottawa Smart Growth Summit, a four-day public event which officially launched the Ottawa $20 / 20$ process, the early contours of the City's new urban environmental policy agenda were presented to the public with a panel of 'international experts' on hand including well-known British urbanist and geographer Sir Peter Hall, urban economist and 'creative city' advocate Richard Florida, and Andrés Duany, architect, planner and founder of the American New Urbanist/Smart Growth movement - to sell the merits of 'smart growth' as a $21^{\text {st }}$ century approach to city building. From the outset of the $20 / 20$ process, regional 'sprawl' was 
presented as the greatest urban environmental problem facing the newly amalgamated City of Ottawa, with the effect that other pressing social and environmental issues were rendered secondary, if not altogether invisible, vis-à-vis the hegemonic crisis of sprawl. As Bunce (2004, p.181) observed in the development of Toronto's Official Plan, the City of Ottawa's support for smart growth intensification pivoted on a carefully crafted 'pro-intensification/anti-sprawl' argument. Drawing on an increasingly pervasive anti-sprawl environmental politics, low-density suburban expansion was cast as wholly 'unsustainable'. Municipal politicians and planners took the position that smart growth-inspired urban intensification and growth management policies constituted the single best (and perhaps only) viable planning solution to combating sprawl and promoting more 'sustainable' urban development practices in the city region. In this respect, following Foucault, the process of 'official planning' appeared to constitute a 'political technology' (Dreyfus and Rabinow 1982, p.185) to the extent that Ottawa residents were given a choice between sprawl and smart growth, effectively depoliticizing planning and the City's new smart growth policy agenda and, in so doing, limiting political space for public deliberation about possible urban environmental policy and planning alternatives within the Ottawa 20/20 consultation process.

During the Smart Growth Summit and in the Ottawa 20/20 public consultations that followed, municipal officials and planners' support for intensification rested on three mutually reinforcing rationales. First, the case for smart growth intensification pivoted on a strong ecological justification grounded in the protection of the Ottawa region's agricultural land, open and recreational spaces, and unique natural environments from continued low-density suburban growth. The preservation of these non-urban environments, it was argued, would not only reduce the city region's future ecological footprint, it would also enhance Ottawa's quality of life. 
Second, in the wake of intense provincial-municipal restructuring and reform, municipal officials argued that future urban growth and development would need to reflect and work within the City's new fiscal realities. By directing new urban development to the city's existing built-up areas where infrastructure and services are already available, officials promised that intensification would be more efficient and cost effective than sprawl and, as such, constituted a more 'fiscally responsible' and 'sustainable' approach to growth. Finally, intensification was presented as an urban environmental policy and planning strategy that would enhance the 'vibrancy' and 'livability' of Ottawa's downtown and surrounding mature urban neighbourhoods inside the city's greenbelt. Planners and officials made the case that directing new growth to the city's existing built landscape in the form of compact, mixed-use urban development would stimulate the creation of a more socially and environmentally 'livable city' by enhancing opportunities for residents to live and work in central Ottawa. Embracing Florida's (2002) argument that to be competitive in the new global knowledge economy cities must be positioned to attract investment and the kinds of young, talented professionals driving knowledge industry growth, smart growth intensification and city centre revitalization were identified as mutually reinforcing strategies geared toward enhancing and sustaining Ottawa's long-term economic competitiveness. Despite the laudable inclusion of environmental and social goals in the process of developing the new Official Plan, the City's preoccupation with economic growth and competitiveness throughout the Ottawa $20 / 20$ process was readily apparent, reflecting an increasingly neoliberalized institutional and policy context at the provincial and municipal scale.

Far from challenging, much less advancing alternatives to, the foundations and features of capitalist urbanization, the City of Ottawa's Official Plan (2003) and its new 'smart growth' planning framework, internalize many of the features of contemporary neoliberal 
governmentalities, policies and development practices. Explicitly drawing on normative interpretations of 'sustainable development' discourse, the Official Plan takes as its starting point that growth is imminent, necessary and good for the new city region. Based on the City's own growth projections, municipal planners and politicians anticipated that the early $21^{\text {st }}$ century would usher in a period of intense growth and change. The changes brought about by the amalgamation of the former lower tier municipalities in the Ottawa area into one 'city region' were compounded by projections that Ottawa's population would grow by approximately 400,000 new residents, pushing Ottawa past the one million mark, possibly reaching 1.2 million by 2021 (City of Ottawa 2003, p. 14). As the centre of Canada's federal public service and with a rapidly expanding high tech sector, city planners also projected 'robust' employment growth, estimating approximately 270,000 new jobs to be created in Ottawa over the coming twenty years (ibid, p.13). Officials and planners were virtually triumphant about the opportunities that would be created by urban and economic growth, enabling the new City of Ottawa to finally shed its perceived small-town image and assume its rightful place as a globally competitive 'world-class' capital city.

The matter of how and where the city would grow was at the very heart of the new Official Plan. By the end of the 1990s, the proliferation of low-density suburban development in the Ottawa region had emerged as a significant urban policy issue. The 1950 Gréber Plan for the National Capital Region, premised on the establishment of a 200 square kilometer greenbelt surrounding Ottawa's existing urban fabric and the decentralization of housing and employment growth to new satellite communities beyond the greenbelt's outer boundaries, initiated a period of rapid suburbanization that would radically transform Ottawa's socio-ecological landscape. In 1974, the first Official Plan of the Regional Municipality of Ottawa-Carleton determined that 
three satellite communities - Orleans in the east, Kanata in the west, and Barrhaven in the south - would spearhead the city's expansion (Fullerton 2005). In the decades that followed, urban growth in Ottawa was concentrated in its suburban fringe. In 1971, only three percent of urban households were located in suburban communities outside Ottawa's greenbelt. Three decades later, in 2001, this number had grown dramatically with twenty-two percent of Ottawa households located in Ottawa's outer suburbs, including Orléans in the east, Kanata and Stittsville to the west, and Nepean, Gloucester, and Leitrim in the south end of the Ottawa city region (City of Ottawa, 2003) (Figure 6.1).

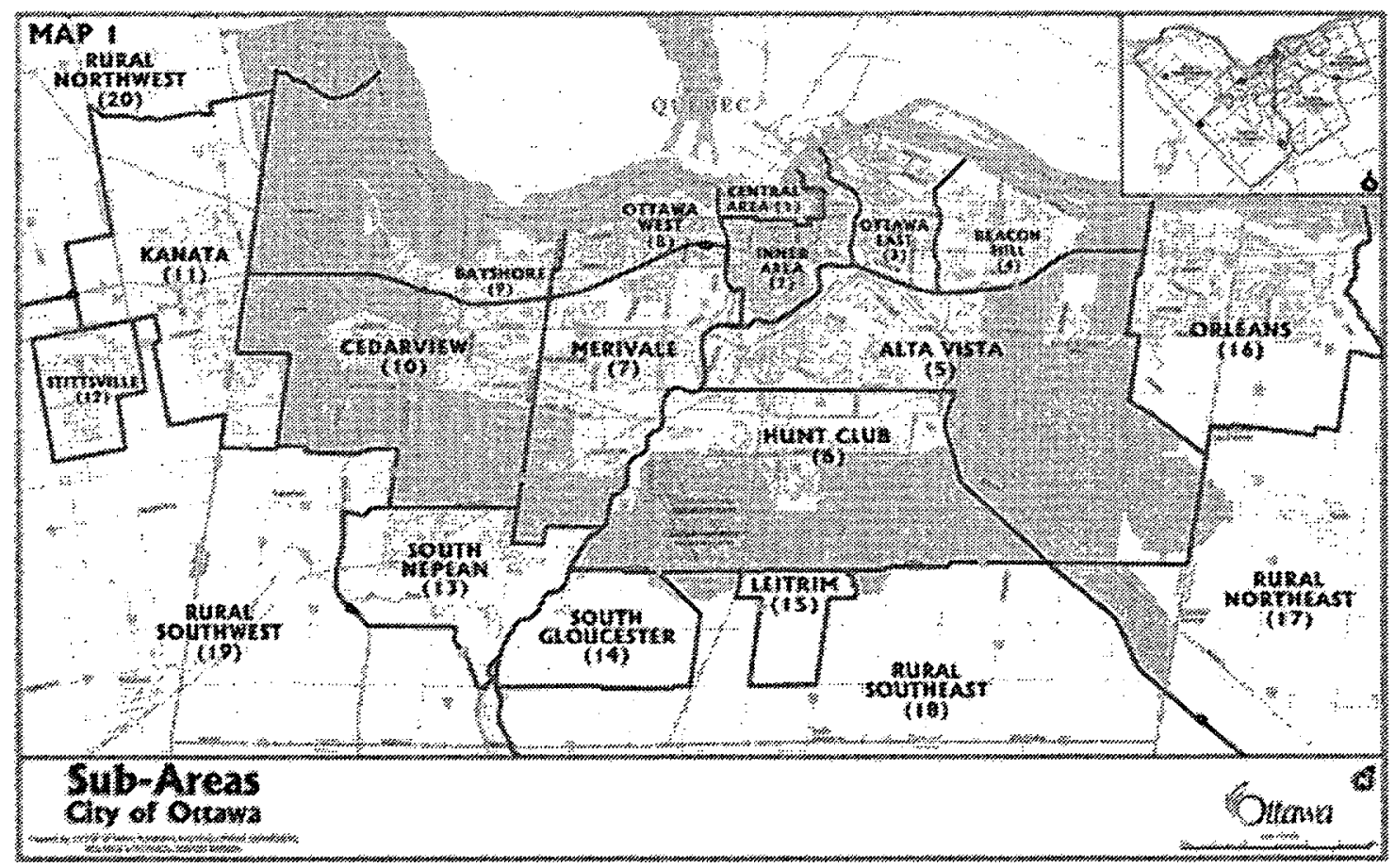

Figure 6.1. Map of Ottawa's sub-areas located within and outside the city's greenbelt (represented in green on the map). Source: City of Ottawa.

With a population expected to grow by up to fifty percent between 2001 and 2021, and given the trend towards smaller household sizes as young adults wait longer to partner and have 
children, the City was anticipating growth in the number of households in Ottawa to increase even faster than the rate of population growth - by up to sixty percent over this time horizon translating into a requirement for nearly 190,000 new homes in Ottawa by 2021 (ibid, p.13). In terms of employment growth, the decentralization of federal civil service jobs over the preceding decades and the more recent high tech boom of the 1990s which saw the proliferation of sprawling office park development in Ottawa's expanding periphery had likewise fuelled demand for and consumption of suburban land. Given these trends and the expectation of robust knowledge industry growth over the City's twenty-year time horizon, planning for the City's future growth was a pressing policy issue.

In the new Official Plan, smart growth, like its counterpart 'sustainable development', takes the form of 'a discourse on growth ... reborn as a discourse that is naturally critical of growth in order for local politicians and planners to be able to sustain it' (Keil and Ronnenberger 1994, cited in Keil and Graham 1998, p.107). Building on the policy and planning priorities established during the Ottawa 20/20 process, the City's smart growth agenda, as outlined in the new Official Plan, is critical of low-density residential and commercial suburbanization on both environmental and economic grounds. Building on a highly popularized anti-sprawl politics in Ottawa, advanced by environmental coalitions like the Greenspace Alliance of Canada's Capital, the Official Plan associates sprawl with the loss of agricultural land, recreational and other open spaces, as well as the fragmentation and/or destruction of sensitive forest and wetland ecologies that serve as wildlife habitat and perform critical ecological services in the Ottawa region and beyond. The Plan, at the same time, identifies sprawl as economically unsustainable given the high cost of extending infrastructure and services to new suburban communities at a time when the municipality is shouldering new financial obligations downloaded by the Province. 
According to the Official Plan, the solution to sprawl is not, however, to halt or even limit growth. Rather, the purpose of the City's new smart growth urban environmental strategy was to rethink how and where to accommodate future housing and employment growth across the city region. Nurturing growth remained a critical urban policy and planning objective, only the geographies of growth had changed.

Smart growth intensification is presented in the Plan as an environmentally 'sustainable' and fiscally sound alternative to low density suburbanization yet, as Gearin (2004) observes in the case of the United States, smart growth is by no means 'anti-growth'. Assumptions underlying the new Plan are that growth is a good thing, something to be encouraged, though carefully managed through 'green' and 'environmentally sensitive' urban and regional planning (City of Ottawa 2003, p.3). In step with prevailing discourses of sustainable development, the Plan endorses a view of smart growth urban intensification as one of 'development in harmony with the environment' (ibid). In this respect, smart growth, like its counterpart 'sustainable development', 'purports to reconcile two old enemies - economic growth and the preservation of the environment - without significant adjustments to the [capitalist] market system' (Escobar 1996, p. 49). Grounded in a politics of ecological modernization, the Official Plan claims that sprawl is 'unsustainable', not growth. Taking a position against sprawl and for 'the environment', in this way, appears to constitute a political maneuver on the part of the City to pursue a new and highly aggressive urban growth and development strategy while claiming to protect Ottawa's urban and regional environments under the guise of 'sustainability'.

Under the new Official Plan, sustainable urban development was to be achieved through a carefully crafted growth management strategy - a process of socio-ecological transformation premised on 'growing in, not out' (City of Ottawa, 2008, p.). In place of traditional patterns of 
low-density suburban expansion, the Plan requires that future housing, commercial and institutional development be directed to designated areas within Ottawa's urban growth boundary established under the Plan. The urban boundary, under the new Plan, defines the area of the city that is already serviced or may be easily serviced in the future with major roads, transit, piped water and sewer infrastructure, and represents a 20-year supply of 'developable urban land' for residential, commercial and institutional uses, as required under the Province of Ontario's Planning Act (City of Ottawa 2003a, p.17). Within the designated urban area, growth is to be directed to locations identified as having 'significant development potential'. Inside the greenbelt, the City's downtown central area and surrounding inner urban neighbourhoods, including traditional and arterial mainstreets were identified as areas that could accommodate significant new development. Outside the greenbelt, new development was to be directed to future growth nodes including suburban town centres, mixed-use centres and employment and enterprise zones along the city's rapid transit network in Orléans, Kanata and South Nepean (Figure 6.2). According to the Official Plan, these areas are expected to become focal points for suburban housing, jobs and commercial activity over the next two decades (ibid, p.17). 


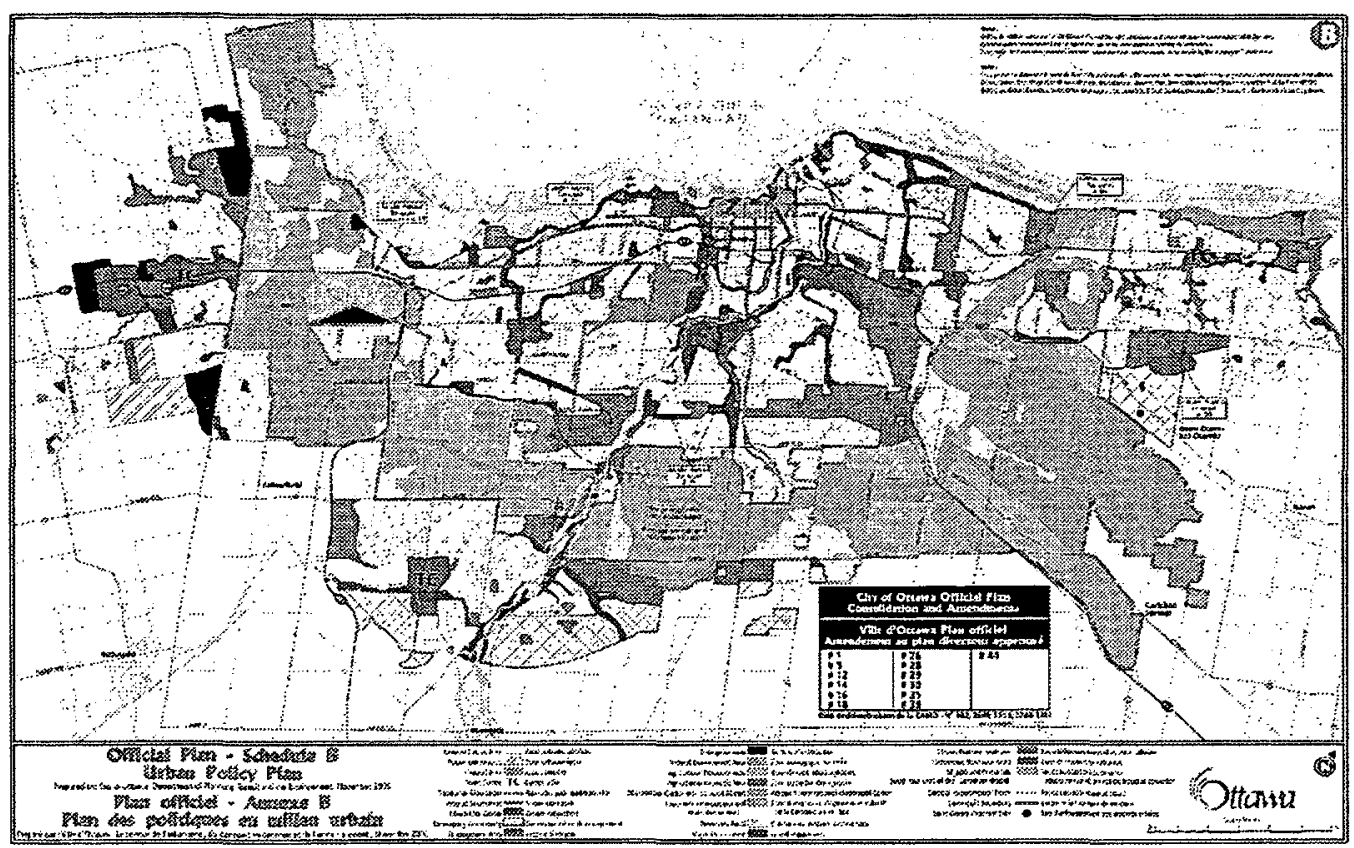

Figure 6.2 The City of Ottawa's Official Plan, Schedule B, Urban Policy Plan. Areas in yellow represent the General Urban Area while areas in pink represent mixed-use centres and towncentres. Source: City of Ottawa (2003).

In Ottawa's 'designated growth areas', future urban development was, and continues to be, expected to occur through intensification. Intensification, in the new Plan, is defined as an urban policy and planning strategy requiring that the density of new urban development, measured in households or employment per hectare, be increased to accommodate greater housing and/or commercial activity than in the past. More specifically, the City defines intensification as 'the development of a property, site or area at a higher density than currently exists' (City of Ottawa 2003, p.19). Intensification, can include the redevelopment of existing properties, including the remediation and redevelopment of brownfield sites; the development of vacant and/or underutilized lots within previously developed areas; infill development; and, the expansion or conversion of existing buildings to create new residential units, including accessory apartments, secondary suites, and rooming houses (City of Ottawa 2008, p.4). 
With Ottawa's population projected to grow by 400,000 new residents, who were expected to form about 187,000 new households between 2001 and 2021, the City's Planning and Growth Management Department released a report, shortly after the adoption of the Official Plan, quantifying the potential for residential intensification in the target growth areas identified in the Plan. In a report entitled Where Will We Live?: Housing Potential in Ottawa (City of Ottawa, 2004), City planners argued that there was the potential for approximately 208,000 new dwelling units that could be achieved through intensification in different parts of the city over the coming years ${ }^{4}$

In projecting the types of new dwellings that will be required to accommodate the City's future growth between 2001 and 2021, the report explains, 'the City must address not only the various demographic changes taking place but also its competitive position as a metropolitan centre both nationally and internationally. Ottawa's ability to attract and retain an educated and diverse workforce, and to further diversify its economy, rests in part on our market's ability to provide a full range of housing to meet all needs' (City of Ottawa 2004a, p.2 emphasis added). According to the Where Will We Live? report, the City was anticipating a 27 percent increase in residential development in the urban area inside Ottawa's greenbelt by 2021 , mostly in the form of intensification and infill development of smaller, multi-unit residential dwellings (apartments and townhomes). Outside the greenbelt, in Orléans, Kanata-Stittsville and South Nepean, where vacant developable land is far more abundant, the City was projecting a 170 percent increase in

\footnotetext{
${ }^{4}$ This estimate does not include residential supply in urban centres outside Ottawa's greenbelt, which are surveyed and accounted for as part of the Vacant Urban Residential Land Survey (estimated capacity of about 69,000 units), neither does it include the Kanata West expansion lands (slated for approximately 6,300 units), residential opportunities in rural villages and in the city's General Rural Area designations expected to accommodate 14,400 units by 2021), or the potential for new secondary apartments in houses (estimated potential of 4,500 units by 2021) (City of Ottawa 2004, p.iii). When all urban and rural lands are taken into account, the City's planning department projected an overall potential supply of about 313,000 dwelling units (ibid, p.iv).
} 
growth expected in urban centres outside the greenbelt, mostly in the form of single detached, semi-detached and townhouse development, with comparatively modest apartment construction (ibid). Although specific intensification targets for different areas of Ottawa would not be established by the City's planning department until 2006, the Where Will We Live? report appeared to suggest that the vast majority of intensification would be concentrated in Ottawa's downtown and in the city's 'mature' residential and commercial areas inside the greenbelt.

As a land-use planning strategy, intensification was presented in the Ottawa 20/20 public consultation process and in the Official Plan as one part of a much larger, and more comprehensive, 'smart growth' urban environmental policy agenda. According to the Official Plan and its supporting Human Services Plan, Environmental Strategy, Economic Strategy, and Talent Plan directing future urban growth to the city's existing built fabric in the form of higher density residential and commercial development promised to advance the City's new 'sustainability' agenda. Smart growth was championed as an urban policy and planning strategy that would protect the City's rural landscapes and natural environments, improve housing affordability and choice in Ottawa neighbourhoods and across the city region, encourage the creation of more 'complete', 'livable' and pedestrian and transit oriented urban communities, while simultaneously bolstering the Ottawa region's long-term economic competitiveness. In short, the City's smart growth policy agenda promised to address, at once, the pressing ecological, social and economic demands confronting the municipality at the beginning of the $21^{\text {st }}$ century. In this respect, 'smart growth' is an exemplar of contemporary ecological modernization in the field of urban policy and planning. The remainder of the chapter examines, in more detail, the discursive architecture of the City's smart growth policy agenda. While the Official Plan presents smart growth as an ideal solution to the crisis of regional sprawl, I develop 
the argument that socio-ecological transformation implied in the City's smart growth intensification strategy has been instrumental in the rolling out a new, and highly interventionist, wave of neoliberal urbanization in Ottawa, motivated by the twin goals of fiscal responsibility and economic competitiveness.

\section{Smart growth in an era of fiscal austerity: the relentless quest for efficiency and cost effectiveness in the provision of municipal infrastructure and services}

While the new Official Plan espouses the ideals of smart growth as a more "environmentally sensitive' and 'sustainable' approach to urban development, the larger political economic context in which the City of Ottawa found itself in 2001, was highly influential in shaping the discourse and policy directions of the new Official Plan. After more than a decade of government restructuring, including the progressive withdrawal of federal and provincial funding for key municipal infrastructure and services (see Chapters 4 and 5), there was mounting evidence that Canadian municipalities were in a state of 'crisis', marked by deteriorating infrastructure, declining air and water quality, traffic gridlock, growing income polarization, economic marginalization and escalating homelessness, not to mention persistent municipal budget crises (Government of Canada 2002). In keeping with policy transformations among other OECD countries, urban quality of life became a key public policy issue in Canada given recent arguments that a nation's competitiveness in the new knowledge-based global economy depends heavily on the quality of life in its cities. In response, new entrepreneurial and competitive styles of urban governance have emerged in Canadian cities that prioritize quantitative physical infrastructure improvements to enhance urban 'sustainability' and 'livability', attract business investment and stimulate economic competitiveness and long-term growth. Given grossly inadequate levels of federal and provincial funding and already limited municipal fiscal capacity, 
the twin imperatives of efficiency and cost-effectiveness in infrastructure development and service delivery has, since 2001 , provided a powerful rationale in support of the City's intensification strategy.

Prior to amalgamation, low-density suburban development was actively encouraged by lower tier municipalities in the Ottawa region on the understanding that growth, of any kind, would increase the municipal tax base and attract new investment. To promote new housing development, development charges (that is, fees charged to residential and commercial developers to recover the costs of extending municipal infrastructure and services to new developments) in the region were kept oppressively low by local councils eager to attract new residential and commercial development in their municipalities. This meant, however, that local governments rarely, if ever, recovered the full cost of new infrastructure from developers, leaving municipalities reliant on federal and provincial transfer payments and the local property tax base to pay for these expenditures.

Following the withdrawal of federal and provincial support for key municipal infrastructure and services, and the eventual downloading of these responsibilities to Ontario municipalities in the late 1990 s, the City of Ottawa confronted new levels of political-economic uncertainty with significant implications for the long-term planning of city infrastructure and services. Although amalgamation translated into modest efficiency gains and cost savings for the municipality, the new City of Ottawa was being forced to shoulder new financial responsibilities beyond its means. Given the City's limited fiscal capacity, Ottawa was grappling with a growing 'infrastructure deficit' and faced the looming possibility of severe cuts to City programs and services to balance the City's budget (City of Ottawa, 2003b). In this context, the City was forced to explore alternative approaches to growth, infrastructure development and service 
delivery as part of the Ottawa 20/20 planning process. Ottawa 20/20's Human Services Plan explains:

Citizens look to the City to manage costs closely, to build Ottawa's financial security in the face of rising infrastructure costs and inadequate provincial and federal support. The need to meet a wide range of needs across a vast geography compels the City to become an innovator. Research and measurement identify the most effective service options, target best practices, isolate problems and help implement new cost- effective service delivery approaches (City of Ottawa 2003 b p.14).

In an era of 'fiscal restraint', Ottawa $20 / 20$ took the position that the new City of Ottawa could no longer afford the high cost of extending roads and transit service, water and sewer infrastructure, ambulance and fire services, and building new libraries and recreation centres in new low-density suburban developments at ever greater distances into Ottawa's periphery. According to the new Official Plan, directing future growth to existing built up areas in Ottawa would encourage the use of existing infrastructure and services, ensure that future development is more efficient and cost-effective and use tax dollars more wisely and is, overall, more 'fiscally responsible' than historical patterns of low density suburban greenfield development (City of Ottawa 2003b, p.12).

The requirement that future urban development make optimal use of existing infrastructure and services, however, reveals much more than the City's preoccupation with reigning in growth related spending and avoiding politically undesirable tax hikes. In keeping with policy transformations at the federal level and in the Province of Ontario, the new Official Plan places a premium on preserving Ottawa's 'livability' (or 'quality of life') as part of a strategy to enhance the city's economic competitiveness and stimulate knowledge economy growth. Although 'livability' under Plan is broadly defined, 'access to city services, amenities and facilities' is presented as essential to Ottawa's livability and, by extension, to the city's ability to attract and 
retain skilled labour and business investment and to realize its vision for long-term economic success (City of Ottawa, 2003b, p.12). According to Ottawa 20/20's Human Services Plan, smart growth planning - as a process of socio-ecological change at an urban and regional scale provides the City of Ottawa with a unique opportunity to make the business of infrastructure and service delivery as efficient and cost effective as possible, thereby ensuring the municipality's long-term financial sustainability and growth objectives, while, simultaneously, preserving Ottawa's high quality of life. The Official Plan, in this respect, appears to seamlessly tie together the imperatives of efficient urban development, fiscal sustainability, and quality of life:

The essence of sustainability is the drive to achieve and maintain a high quality of life both now and in the future. In the context of human services planning, the goal is to provide better access to the basics of a healthy, fulfilling life, to enhance the networks that build communities and neighbourhoods, and to ensure that initiatives are sustainable over time. Sustainable growth is essential to achieving our vision of $A$ Responsible and Responsive City, a principle of Ottawa 20/20 (City of Ottawa 2003b p.12; emphasis added).

According to the Human Services Plan, sustaining growth and quality of life, in an era of government restructuring and the rescaling of responsibilities, requires 'new ways of doing business' (ibid, p.12). The Plan calls for 'the transformation of the City's services to a fully sustainable model', one premised on '[m]aximizing the use of existing resources and investment ... to empower change with nominal increases in cost' (ibid). In the vernacular of neoliberal urbanism, the challenge of the new Official Plan was 'to do more with less'. To ensure that future growth is financially sustainable, the Plan requires that future 'growth pay for itself'. Development, according to the Human Services Plan, was to be put on a strict 'pay-as-you-grow' footing, by restricting long-term debt financing, establishing standards for fees and rates of programs and services (no doubt accompanied by user fee increases), incorporating future 
operating costs into project capital budgets and identifying the true lifecycles replacement costs of City assets (ibid, p.13). On the service delivery side, the Plan also calls for a shift towards more 'flexible service delivery models' that 'target and deliver appropriate services to specific communities', in place of a 'one-size-fits-all' model (ibid). Quite crucially, the language of 'flexible service delivery' appears to empower the City to channel municipal investment to 'priority areas' - investments, for example, with the potential to advance the City's vision of economic growth and competitiveness. Meeting the financial challenges of growth, according the Human Services Plan, also requires that the City 'aggressively pursue increased funding', through increased development charges, new public/private partnerships, as well as negotiating with other levels of government for more equitable funding arrangements and allocation of responsibilities - what has, more recently, been described as 'uploading' - to close the funding gap for municipal infrastructure and services in Ottawa (ibid, p.13-14).

The language of the Official Plan, which presents 'smart growth' as an ideal strategy to promote efficient and cost effective urban development that optimizes the use of existing infrastructure and services and, in so doing, controls municipal spending while avoiding spiraling tax increases, offers a striking example of the way in which neoliberal restructuring and reform experiments at other scales become internalized into local urban policy (and planning) regimes. The politics of urban growth, since the Plan's adoption in May 2003, suggests that 'smart growth', as an urban environmental policy experiment, has formed part of a much broader shift towards a neoliberal governmentality in the City of Ottawa premised on the twin goals of efficiency and fiscal sustainability in urban planning and policy development. Though policies supporting compact urban development were expected to produce efficiencies in terms of infrastructure development and the delivery of municipal services, the City's escalating budget 
deficit required that 'difficult choices' be made (City of Ottawa 2004a, p.5). Ottawa's new smart growth development agenda formed part of a much larger, aggressive City-led strategy to reduce spending on municipal programs and services. Although amalgamation delivered modest cost savings to the new municipality, the City's 2002 budget process identified a significant funding gap in the City's capital program - a funding gap that was forecast to reach $\$ 270$ million by 2006 , or approximately $\$ 100$ million each year from 2004 onward (City of Ottawa 2004b). In response, the City prepared a long-range financial plan (LRFP) to outline the City's operating and capital needs, and to recommend strategies to address the funding gap. The key finding of the LRFP was that "without a change in funding mechanisms and with the amalgamation program complete, Ottawa would reach a point where it was no longer able to continue to absorb normal budget pressures. When that point was reached, City Council and residents would have no choice but to address the pressures by reducing services or raising property taxes' (City of Ottawa 2004a, p.5).

Despite the GST rebate passed by the federal Martin government earlier in 2004 as part of its 'New Deal for Cities' to fund municipal infrastructure development, the City anticipated that cuts to city programs and services were imperative. Only a month after Council approved the new Official Plan, in June 2003, a Universal Program Review (UPR) was launched as part of the City's long range financial planning and to inform Ottawa's 2004 municipal budget process. The UPR, in a report to Council, outlined an aggressive municipal restructuring program to 'streamline' the City's bureaucracy, avoid duplication, and seek out 'administrative efficiencies' all in an effort to reduce internal municipal expenditures. In addition to massive cuts to the City's administrative staff, the UPR proposed the 'rationalization' of City program and service expenditures, 'enhanced service level reductions' (that is, reductions in service levels or 
activities that go beyond what the City is strictly required to do under provincial legislation, or what could be considered a 'base level' of municipal service), as well as reductions in 'baseline service levels' with the most severe cuts to the City's public transit service. Despite the City's desire to avoid a property tax increase, during the consultation phase of the 2004 budget process community-based organizations concerned about arts, culture, recreation, and the City's health and social services expressed strong support for a tax increase if it meant that valued City programs and services would be protected (Social Planning Council 2004, p.3). In the final budget, Ottawa City Council opted for a 2.92 percent property tax increase, avoiding many, though by no means all, of the cuts proposed by the UPR. The 2004 budget implemented extensive administrative reductions and $\$ 30.4$ million in cuts to City programs and services (City of Ottawa 2004c). According to People For A Better Ottawa, a local network of social service providers, community organizations and other urban activists, the 2004 budget marked the beginning of a new phase in urban governance in the City, characterized by often deep annual cuts to city programs and services, justified on the grounds of efficiency and cost savings in an era of government downloading.

The neoliberalization of urban governance in Ottawa intensified following the 2006 municipal election. Local businessman, Larry O'Brien, campaigned and won the Ottawa mayoral race on the promise of 'zero means zero' property tax increase and a commitment to revisit the City's plans to expand Ottawa's light rail system. Shortly after taking office, O'Brien and the newly elected municipal council voted against the proposed North South light rail project on the grounds that the City's assumptions about growth, development and increased ridership were flawed, making the plan financially unsustainable. A Mayor's Task Force on Transportation was established headed by former federal transport minister, David Collenette, to define a new 
direction for an integrated transportation plan for Ottawa, including light rail, that was financially sustainable and would strengthen Ottawa's competitive advantage, making it a more attractive place to live, work and invest. Once the transit issue had been officially delegated, O'Brien made it his mandate to put the City of Ottawa on a 'firm business footing' both to deliver on his promise of a 'zero-means-zero' budget but also as part of his 'transformation agenda' premised on 'bring[ing] an entrepreneurial spirit to city hall' (O'Brien 2007a, p. 1).

As part of his entrepreneurial city vision, O'Brien launched his ' 1000 days of transformation' campaign in June 2007. The 'three pillars' of this transformation agenda concerned service delivery, council governance, and the City of Ottawa's long-term financial stability. The intent of this restructuring process was to apply a 'business like approach to Ottawa's municipal government' (O'Brien 2007b, p.1) with the goal of transforming the City of Ottawa into a thriving, globally competitive city - 'a city with swagger':

Transforming our city government from good to great in everything that we do ... and every citizen that we serve. We know that cities are the engines of the global economy. And the world's best cities are magnets that amass knowledge, people and create wealth. The world's best cities are also safe, secure and sustainable. As well, the citizens that live in these great cities have a certain swagger about them. I know that Ottawa can become one of these cities with swagger. Transformation is the path to this destination (O'Brien, 2007a, p.1).

The foundation of O'Brien's transformation agenda was a commitment to strengthen the city's economic competitiveness and 'reposition Ottawa on the global stage' (ibid, p.2). To sustain Ottawa's competitive advantage in the high technology, tourism, finance and clean energy sectors, it was argued, 'industry must attract the most talented workers from all across the globe and develop home grown talent at the same time' (ibid). On the role of local government, the mayor argued: 
And the role that we must play as a city is to step up and implement policies to give our citizens that best quality of life ... from world-class transportation to competitive taxation rates to clean and safe neighbourhoods. In other words, do the things that make Ottawa safe, secure and sustainable (ibid).

In keeping with the logics of neoliberal urbanism, stimulating industry growth depended on attracting the right sort of people to Ottawa - the 'talent' said to be driving the new knowledge economy. This new economic imperative demanded the active intervention of local government to create the kinds of policies that enhance urban 'livability' while keeping municipal spending and taxes as low as possible. In terms of municipal governance, $\mathrm{O}^{\prime}$ Brien's transformation agenda included efforts to streamline Council decision-making by delegating greater authority to Standing Committees, ward councilors and City staff, thereby enabling Council to focus on 'strategic directions' and to expedite approvals. Building on earlier debates concerning the longterm financing of city programs and services, 'transformation' also centred on the 'what' and 'how' of municipal infrastructure development and service delivery in Ottawa. In an era of upper tier government retrenchment, delivering high quality municipal services, argued the mayor, requires a careful growth management strategy, strategic investment in infrastructure, and a service delivery model that privileges efficiency and cost effectiveness above all else: 'if we want SMART GROWTH, it requires SMART MANAGEMENT' (O'Brien 2007b, p.2, emphasis in original).

Reflecting this transformation mandate, the City Strategic Plan for 2007-2010 emphasized the importance of intensification to ensure that future urban development optimizes the use of existing infrastructure and services. Maximizing infrastructure and service efficiencies in this way, it was argued, would enable the City to sustain long-term growth, reduce costs borne by the municipality (and the taxpayer), and maintain the City's high quality of life (City of Ottawa 
2007a, p.3). During the development of the Strategic Plan, the City projected a total taxsupported infrastructure funding gap of over $\$ 2$ billion from 2007 to 2016 , due in no small part to the withdrawal of financial commitments from upper levels of government:

Our quality of life here in Ottawa is hard to beat. The City is doing well but there are challenges ahead if we are to maintain our current standard of living. Canadian cities simply do not have the financial tools to meet all of their responsibilities. Our federal and provincial partners have an important role and must help.

While cities deliver most of the services and build most of the infrastructure that support economic growth, they receive almost none of the provincial and federal tax revenues generated by that growth. Ontario municipalities are further disadvantaged by having to operate and fund health and social service programs that are mandated by the Province.

Ontario cities must fund services with only three main tools under their control: property taxes, user fees and development charges. Experts agree that, although the federal and provincial governments have begun to provide municipalities with new funding streams by sharing a small portion of their gas taxes, funding from those governments remain inconsistent and inadequate.

The City of Ottawa is working with other larger cities in Canada to try to change the municipal fiscal imbalance. In the meantime, Ottawa must continue to operate within the existing fiscal framework until real and meaningful change occurs at upper levels of government (City of Ottawa 2007b, p.2).

In this political economic context, an urban environmental growth strategy focused on efficiency and cost savings, it was argued, would liberate scarce municipal resources, enabling the City to address the escalating backlog of needed infrastructure repair and rehabilitation and to support 'strategic initiatives' to build new infrastructure (City of Ottawa 2007a, p.23). Infrastructure targeted for repair or replacement, in the City Strategic Plan, focused largely on the city's roads and highways given their 'important role in Ottawa's economy and the quality of life of its residents ... allow[ing] for the free flow of people, goods, and services'. Not unexpectedly, the City's preoccupation with road expansions generated considerable public opposition, particularly from local environmental activists, like Ecology Ottawa, that viewed the City's road building 
strategy as inconsistent with Ottawa 20/20's vision to support compact, transit-friendly urban development patterns. In conjunction with new road building, the Plan also included a funding strategy to 'close the gap' on sanitary and storm sewer and water line replacement to accommodate residential intensification inside Ottawa's greenbelt, and the renewal of City facilities to LEED (Leadership in Energy and Environmental Design) standard to increase the efficiency, as well as the 'green' image, of City buildings. Large-scale 'strategic' investments in new city infrastructure included the $\$ 159$ million redevelopment of the Ottawa Convention Centre, expenditures which were justified in the City Strategic Plan on the grounds that facilities such as this are of 'city-wide significance' (rather that serving the needs of a select few) and are 'key to vibrant urban centres', having the potential to become 'iconic structures that model the type of community we want to be' (City of Ottawa 2007a, p.27).

The final pillar in the City's transformation agenda concerned the long-term financial sustainability of the City of Ottawa. In addition to closing the infrastructure renewal gap through a combination of tax and rate supported funding streams, pursuing new sources of funding (such as gas tax revenue) to enable the City to meet its growing financial obligations, and pressing for the upload of social services, social housing and public health to upper levels of government, the City Strategic Plan stressed the need for new urban development to become 'self-financing' - in other words, 'making growth pay for itself' (City of Ottawa 2007a, p.64). In the City of Ottawa's 2007 fiscal framework, described as 'the City's high level roadmap to sustainable finances' and 'the financial constitution that guides all financial decisions' taken by city council, urban growth management again emerged as a key priority (City of Ottawa 2007c, p.1). Alongside the Official Plan's requirement that future urban development be compact and optimize the use of existing infrastructure and services, the fiscal framework requires that the 
City's development charges bylaw will be used 'to recover the costs of growth to the full extent permitted by [provincial] legislation (thereby minimizing the financial burden of the costs of growth on existing residents)' and that 'other methods will be explored with developers/others to fund growth related projects that are not eligible for development charges' (ibid, p.6). Quite crucially, the discourse demanding that 'growth pay for itself' appeared to be as much a political tactic as it was a financial one given simmering resentment, particularly among urban residents inside Ottawa's greenbelt, over the financing of suburban growth through existing property taxes.

In preparation for Ottawa's five year Official Plan Review (OPR), which commenced in 2008, the City commissioned a private consulting firm, Hemson Consulting, to undertake a review of the impact of new urban development on the City's operating and capital budgets, no doubt hopeful that study findings would make a powerful case for the City's 'smart growth' urban policy agenda. The review was to compare the relative net cost to the municipality and to taxpayers of development inside the greenbelt, in urban areas outside the greenbelt (but within the urban boundary), within villages located in Ottawa's rural areas, and in rural areas outside village boundaries, to inform City decision-making concerning future urban growth planning and development decisions. The findings of the study, while not surprising, generated intense public debate and opposition, setting the tone of the entire OPR process. In a nutshell, the Hemson Report found that 'compared to the City-wide average, housing units inside the Greenbelt are less costly to serve from a municipal perspective than units in the other three categories of location' (Hemson Consulting, 2009, p.24). When the projected tax yields by location were set against the comparative net expenditures to provide new development in these locations with infrastructure and services, the study found that 'development inside the Greenbelt produces a 
substantial positive fiscal result both on a per household and per capita basis' (ibid, p.26). New urban development outside the greenbelt, but inside the urban boundary, comes close to meeting costs but still produces a net deficit for the City, while development in villages and in scattered rural developments produces a much larger net loss according to the study (ibid).

The 'Hemson report', as it came to be known, made a strong case for intensification as an urban strategy to optimize the use of existing infrastructure and services, reducing the costs of new development borne by the municipality and taxpayer. The report and its findings also garnered support from Ottawa residents, sparking intense public outrage during the OPR, particularly among residents living in neighbourhoods inside Ottawa's greenbelt. In response to a proposal by City planners to expand Ottawa's urban boundary by 840 kilometers to accommodate new suburban development, community associations, organized under the umbrella of Ottawa's Federation of Citizens Associations (FCA), charged that property taxes collected inside the greenbelt were being used to 'subsidize' continued low-density suburban sprawl, bleeding neighborhoods inside the greenbelt of much needed public investment in infrastructure repair and social services. During the OPR an intense class-based growth politics emerged in Ottawa as the FCA, representing primarily middle class and more affluent inner urban neighbourhoods, contested the proposed boundary expansion and pressed City planners and officials to abide by the Official Plan's intensification mandate to promote efficient and cost effective patterns of urban growth - this despite mounting opposition to intensification, in the form of high rise condominium development, in many of the same inner urban neighborhoods represented by the FCA since the Official Plan's adoption in 2003. In effect, the Hemson report and the pubic opposition it sparked during the OPR served to legitimate and embolden, rather than challenge, the City's narrow concern with efficiency in its intensification planning and 
policymaking.

Smart growth, 'sustainability' and the 'livable city': Residential intensification as $21^{\text {st }}$ century urban competitiveness strategy

Although improving efficiency and optimizing growth-related municipal spending in a period of intense neoliberal restructuring was certainly a driving motivation in support of smart growth intensification in the new Official Plan, the language of the Official Plan and more recent intensification policies suggests that intensification has also been central to the rolling out of a new wave of neoliberal urbanization premised on strengthening and sustaining Ottawa's ability to compete in the emerging 'knowledge economy'. From the outset of the Ottawa 20/20 planning process in 2001, municipal politicians and planners presented smart growth intensification as an urban environmental strategy with the potential to transform Ottawa into a 'world class' and 'eminently livable' city region capable of attracting the best talent and knowledge economy investment, thereby stimulating industry growth and job creation (City of Ottawa 2003a, p.15).

As has been observed elsewhere in North America and Europe, the City of Ottawa's 2003 Official Plan hinged on a highly strategic and politically powerful grafting of economic competitiveness, urban livability and sustainability discourses that draws its inspiration from Richard Florida's ideas concerning the significance of what he terms the 'creative class' in the new economy - ideas that have become highly influential in $21^{\text {st }}$ century urban policymaking (Bunce 2004; While et al. 2004; Peck 2005; Gibbs and Krueger 2007; McCann 2007). In the new knowledge-based 'creative economy', Florida insists that competitive, successful cities are those that can attract investment and industry growth by first attracting the right kind of people, namely, young, highly educated knowledge workers - the 'talent' - whose skills and creativity 
are said to drive ideas and innovation in new technology, the sciences, engineering, architecture and design, arts and entertainment, and other knowledge economy industries. The premise of Florida's creative city thesis is that young urban professionals are attracted to cities, particularly city centres, that are socially and environmentally 'livable'. As cities find themselves locked in a global competition for talent, success in this new economy is thought to depend on developing the kinds of urban environments valued by this select group of creative professionals. According to Florida (2002), 'creatives' crave dense, vibrant and trendy urban environments that offer a rich diversity of lifestyle amenities and experiences. Creating the kinds of urban environments, amenities and 'qualities of place' that attract 'talent' becomes top priority for cities concerned with drawing in new knowledge industry investment, promoting economic development, and sustaining long-term growth. As part of this shift in urban policy, city planning is assigned the role of facilitating the physical transformation of the city required to enable the kind of social and economic transformation explicated by Florida's 'creative city' argument (Cowen, 2004). Downtown and waterfront revitalization projects; luxury 'eco'/'green' condominium development (including brownfield remediation and redevelopment), investments in pedestrian and cycling infrastructure and public transit for urban commuters, and policies to protect greenspaces for their lifestyle and recreational amenity value, are among the planning and development strategies deployed by municipalities to create and market themselves as 'livable' and 'sustainable' city regions and as attractive places for the young urban professional class to, as the mantra goes, 'live, work and play' (Bunce 2004; While et al. 2004; Peck 2005; McCann 2007).

Enhancing Ottawa's economic competitiveness and its ability to attract knowledge industry investment constitutes a key urban policy objective in the City's Official Plan. In 2001, Ottawa's 
economy was considered to be strong and rapidly diversifying. Once dominated by federal service employment, Ottawa's economy expanded substantially during the 1990 s in the high technology sector. With three universities and a combination of government and private research facilities and an active business community and well-educated work force, the Official Plan presents Ottawa as a city positioned as an emerging global competitor in the new knowledge economy:

The health of a twenty-first century city is measured by the talent of its workers, the creativity of its citizens, its appreciation of diversity, the strength of its high-tech sectorand its willingness to collaborate for success. Ottawa is positioned to compete. It ranks first in Canada for talent, third in size of technology workforce and sixth in the number of creative and artistic citizens. And it is growing a collaborative culture that embraces every sector of the economy....

Many Ottawa businesses now compete globally. Strong and innovative technology, tourism and professional services industries support its economic prosperity and our telecommunications companies lead internationally. Other sectors such as creative industries, wireless technology and environmental technology are seedbeds for future global competitors (City of Ottawa 2003c, p.i).

After more than a decade of upper level government restructuring, and the downloading of responsibilities for urban infrastructure and services to fiscally constrained municipalities, supporting Ottawa's thriving knowledge economy and creating an attractive climate for investment in new and innovative industry clusters were considered imperative not only in terms of jobs and wealth creation but also to ensure the City's long-term fiscal sustainability and its capacity to invest in municipal infrastructure, programs and services. The assumption that the benefits of a strong, competitive urban economy would 'trickle-down' and enable the City to invest in new and much needed infrastructure and services, makes a powerful case for municipal intervention and policy development in support of Ottawa's future economic development: 
The [Official Plan's] Economic Strategy acknowledges that individual companies drive a city's prosperity. The more successful the export-oriented businesses, the more wealth flows back into the local economy, which in turn fuels further rounds of local purchases and employment. The result of export success is not just jobs and wealth, but an increased capacity to invest in and support other priorities within our city - from parks to hospitals to schools to theatre and music.

As Canada's capital city, Ottawa offers its businesses a unique synergy of research capacity, talent and quality of life. The city encompasses a diversity of business interests and sectors-ranging from a $\$ 10.5$ billion advanced technology sector to a $\$ 400$ million agricultural sector. It is an attractive destination for living-a green metropolis with an electric and creative business culture.

Ottawa is rapidly developing a critical mass of knowledge and entrepreneurial expertise that-with the right support-will sustain the city and propel it farther into international competitiveness (City of Ottawa 2003c p.1, emphasis added).

In the context of intense and globalizing inter-urban competition, the Official Plan identifies Ottawa's long-term economic competitiveness and knowledge industry growth as key urban policy priorities, requiring active policy intervention and planning on the part of the municipality. Taking a page from the 'competitive city' and 'entrepreneurial city' scripts that have come to define more recent waves of urban neoliberalization in Canadian policy debate (Kipfer and Keil 2002), the Official Plan's Economic Strategy makes the case that Ottawa's long-term economic competitiveness hinges on the City's ability to attract and retain the kinds of talented, highly educated knowledge workers and robust business investment driving growth in Ottawa's high tech and other creative industry clusters:

Ottawa is competing with other cities for new investment and quality jobs. Globalization and the Internet have lessened the importance of proximity to customers. However, proximity to a skilled labour force remains a critical factor in determining business location. The modern workforce is very mobile-attracted to the best jobs in the best cities for the best wages. To win its share of the global markets for our export industries, Ottawa needs the right conditions to attract those workers. The city's skilled workforce, quality jobs, green spaces, low crime rate, clean air and water are part of that attraction. (City of Ottawa 2003c p.13) 
In keeping with Florida's (2002) ideas, the Official Plan is premised on an assumption that skilled labour and business investment are attracted to cities that are socially and environmentally 'livable'. In everyday policy vernacular, 'livability' is commonly used to refer to the quality of life experienced by residents living in a city, including one's ability to access infrastructure and services, healthy and affordable food, clean air, affordable housing, meaningful employment, opportunities for leisure and recreation, green spaces, parks and the like (Timmer and Seymoar 2005). However, as McCann (2007, p.188) observes, 'livability', has proven to be a powerful and often problematic concept. In contemporary urban politics and policymaking McCann argues that discourses of urban livability and economic competitiveness have become so thoroughly enmeshed that they must be understood to constitute 'a geographically selective, strategic, and highly political project' (ibid). In the context of the Official Plan, the City's intention to transform Ottawa into a more socially and environmentally livable city cannot be separated from its ambitions to bolster the city's long-term economic competitiveness. The argument developed here is that despite its progressive elements, Ottawa's 'smart growth' policy agenda appears to mobilize a highly selective interpretation of urban livability (and sustainability) - one centred on the repopulation and revitalization of Ottawa's city centre.

As Bunce (2004) observes in the case of Toronto, support for 'smart growth' inspired urban intensification in Ottawa's Official Plan rests, in significant measure, on an implicit relationship between the physical and economic revitalization of Ottawa's downtown and surrounding mature residential and commercial districts and the city's ability to attract skilled professionals and investment and to sustain knowledge economy growth. The City of Ottawa's interest in intensification as an urban revitalization strategy is not, however, new to the 2003 
Official Plan but, rather, dates back to the early 1990s as a policy response to the large scale depopulation and decline of the city's downtown over the preceding decades. Building on the momentum of earlier revitalization efforts, urban intensification became the cornerstone of the 2003 Official Plan's 'smart growth' agenda. The City's new intensification strategy is geographically expanded beyond the downtown core, reconceptualized and re-presented to the public as a city regional approach. While the physical and economic revitalization of Ottawa's downtown districts remains a key priority of the new Plan, the city's mainstreets, mixed use centres, enterprise zones, and locations close to the city's rapid transit nodes are also identified as having significant potential for intensification and redevelopment over the Plan's twenty year time horizon. As a city regional approach, the rationale in support of 'smart growth' intensification is also expanded, (re)presented as simultaneously an environmental strategy to protect Ottawa's urban and regional ecologies from the perils of sprawl and as part of a broader economic strategy to stimulate new high density urban development and create more socially and envionmentally 'livable' and 'vibrant' neighbourhoods in key districts across the city region and to support (and render economically feasible) the City's investment in a new regional light rail system, both of which were expected to enhance Ottawa's livability and economic competitiveness at a regional and global scale. The City's proposition that smart growth intensification represents an ideal urban policy and planning strategy to address, at once, the pressing issues of environmental stewardship, urban livability and economic competitiveness, I argue, is suggestive of the kind of 'win-win' political discourse that lies at the very heart of the politics of ecological modernization.

At the scale of the city region, the Official Plan's intensification mandate stresses the imperative of curbing urban sprawl in order to protect Ottawa's regional environment from 
unnecessary, or at least premature, suburban expansion. According to the Plan, directing future urban development inward, to existing built-up areas, is expected to reduce development pressures in the city's periphery and on Ottawa's extensive 'natural features', rural landscapes, and outdoor recreational and leisure amenities - assets thought to make Ottawa a 'unique', 'livable' and 'green' city region. As the Official Plan's Environmental Strategy (City of Ottawa 2003d, p.2) argues:

From the City of Ottawa's perspective, we have the opportunity to influence many of the environments that each of us experiences daily. This includes the large geographic area of $2760 \mathrm{~km} 2$ that comprises the City. Also, as the nation's capital, we enjoy the benefits of having Canada's Parliament buildings, a range of wonderful museums, the National Arts Centre and National Gallery of Canada in our backyard. As we move to the landmarks and characteristics of the city's natural environment, the list is equally impressive.

Residents and tourists alike treasure the Ottawa River as a major feature of our city. Historically, the Ottawa River provided an east-west trade route and a transportation system for logs. Now, the Ottawa River and its border of greenspace provides a respite for young and old, for those who wish to sit and gaze and think, to explore nature, as well as a place for more active pursuits like sailing, cycling, walking or training for the Olympics. This river also provides the drinking water for 723,000 residents in Ottawa through the City's water treatment service that provides some of the highest quality drinking water in Canada. Wildlife also thrive within the waters and along the vegetated shores of our rivers. When looking for a place to think and where one can appreciate the beauty of our rivers, a captive destination is Rideau Falls, where the Rideau River empties with a roar into the Ottawa River.

Natural beauty and recreational opportunities also abound along the Rideau Canal and Rideau River that flow through our City. These systems provide a north-south water link for our City, support a majestic greenway corridor and represent a rich part of the early history of Ottawa. Both the Canal and the River attract thousands of residents and tourists each year. This provides a sense of vitality to our community. However, we must also take care of these systems to ensure their continued enjoyment. ...

Connected to the river systems and watersheds of our City is a network of other natural features including forest and wetlands. ... Other greenspaces include meadows, parks and other areas of open space. Likely the most recognized feature of the greenspace network is Ottawa's Greenbelt as it borders a significant portion of the City's urban or developed area. The Greenbelt, established by the National Capital Commission through land acquisition beginning in the late 1950s, is a source of pride and accomplishment for residents and a marvel for visitors flying or driving into the City. Major natural environment areas include the South March Highlands, Marlborough Forest and Stony 
Swamp to the west, and as well as Mer Bleue and Petrie Island to the east. Approximately $28 \%$ of the City's land area is forested, the majority of which is located within the rural areas of the City. Almost $43 \%$, or $1200 \mathrm{~km} 2$, of the City is greenspace, including these forests, natural environment areas, open spaces and more than 850 parks.

In the context of the Official Plan, smart growth constitutes a policy instrument that incorporates aspects of environmental stewardship while still supportive of growth in the form of high-density development in existing built-up areas of the city. Without diminishing the City's commitment to protect Ottawa's natural and rural environments from unregulated low-density suburban expansion and to encourage patterns of development that support more environmentally progressive transportation choices such as public transit, its smart growth intensification strategy suggests a 'selective incorporation of environmental goals' (While et al. 2004, p.551), goals that arguably advance the City's economic strategy to attract new business investment and talent and transform Ottawa into a world class capital city. While the protection of the City's unique natural features and amenities may well serve the recreational and lifestyle aspirations of Ottawa's more affluent populations, the strategy offers little, for example, to ameliorate the everyday built and natural environments in which the City's more vulnerable populations live. Difficulties securing stable access to affordable and appropriate housing, the deleterious (and often hazardous) condition of the city's aging social and rental housing stock, access to safe and enjoyable park space for children in lower income neighbourhoods, and the availability of (and gendered safety concerns associated with) evening public transit service to accommodate the transportation needs of shift workers - prominent features of the everyday lived environments of Ottawa's low income and vulnerable residents - are not given equal or adequate attention, suggesting that the Official Plan's definitions of urban environmental 'sustainability' and 'livability' are inherently partial (in both senses of the word) and political, driven more by the imperatives of economic 
competitiveness than by a more progressive commitment to social and environmental justice.

In the Official Plan, the City equally, if not predominantly, champions intensification as an urban environmental policy and planning strategy on the grounds that high density mixed use development supports the creation of more 'compact', 'livable' and 'complete' urban communities which it defines as neighbourhoods that offer 'a good balance of facilities and services to meet people's everyday needs, including schools, community facilities, parks, a variety of housing, and places to work and shop' (City of Ottawa 2003a, p.16). Compact development that accommodates a range of housing, employment and institutional uses and offers retail and commercial services, as well as cultural, leisure and entertainment amenities all in the same place, it is argued, are more 'livable' to the extent that they increase opportunities for (some) residents to live nearer to places of employment, retail, and recreation and make neighbourhoods more 'pedestrian friendly' and 'transit-oriented' reducing dependence on private automobile travel and improving local air quality.

In terms of housing, the Official Plan and City Housing Strategy (2007) both espouse a view of intensification as a planning instrument that is responsive to changing demographics and a housing market that, since the late 1990s, has begun to shift towards smaller and denser forms of housing in Ottawa's downtown and in older residential neighbourhoods in close proximity to the urban core. To the extent that intensification accommodates a broader range of housing needs than traditional suburban development, the Plan highlights the potential for higher density urban development to enhance housing affordability and choice, supporting the creation of more diverse and inclusive neighbourhoods. The Official Plan, in fact, elaborates a view of urban livability in which '[a]ffordable and appropriate housing for all residents is the fundamental building block of a healthy and livable community' (City of Ottawa 2003a, p.47). Quite 
crucially, however, the City's intensification and housing strategies are only nominally progressive as they lack clear and enforceable policies requiring that new high-density development include the provision of affordable units for lower income residents. In this respect, the City's vision of a 'livable city' and 'livable neighbourhoods' appears to privilege marketdriven urban development processes and the housing desires of a select few - namely, retirees and empty nesters looking to downsize and live closer to central services and young urban professionals who gravitate to trendy downtown residential locations (City of Ottawa 2007, p.35) - over the need for truly affordable, single and family-oriented housing (especially rental housing) close to public transit, schools, grocery stores, social programs and services, and other everyday amenities. This particular argument is further developed in Chapter 7.

Although discursively (re)presented in the Official Plan as, first and foremost, a city regional approach to curb sprawl and create a more compact, sustainable and livable city, the substance of Ottawa's intensification policies suggests that the dominant preoccupation of municipal officials and planners has been to encourage market-driven high density urban development in Ottawa's downtown and nearby residential and commercial districts in an effort to repopulate and revitalize the city's inner urban environments. Not unlike the early intensification efforts of the former Regional Municipality of Ottawa-Carleton during the 1990s (see Chapter 7), the City's Official Plan and supporting intensification policies are premised on a presumed relationship between the City's economic success and the repopulation and revitalization of the Ottawa's downtown core and target areas in the city's built landscape.

The fusion of urban sustainability, livability and economic competitiveness discourses in the City of Ottawa's intensification strategy is perhaps best exemplified in the extraordinary policy attention directed to the matter of urban design in recent years. During the development of 
Ottawa's Official Plan, the City's of Ottawa commissioned a private consulting firm, Urban Strategies Inc., to prepare an urban design strategy for Ottawa's downtown. The Downtown Ottawa Urban Design Strategy (DOUDS) establishes a policy framework for building urban design into the City's intensification policies and downtown revitalization and development practices on the understanding that an intensified, livable, and aesthetically beautiful downtown core is key to attracting business investment, skilled labour and tourists to the city region. The privileging of urban design, over and above other possible (and more progressive) planning goals, constitutes what Boudreau et al..(2009, p.114) describe as an 'aestheticization of planning' and is suggestive of the kind of 'entrepreneurial city' strategy that has accompanied the rise of urban neoliberalization (Brenner and Theodore 2002; Kipfer and Keil 2002).

The Official Plan espouses a view of downtown Ottawa as 'the economic and cultural heart of the city and symbolic heart of the nation' (City of Ottawa 2003a, p.19). As Canada's capital city and as the centre of its federal service, finance, and knowledge industry sectors, Ottawa's downtown has, not surprisingly, become a focal point of the City's urban policy and planning in recent years. In the DOUDS document, support for a comprehensive downtown urban design strategy is based, in significant measure, on an expressed concern that, in an era of intensifying inter-urban competition, Ottawa's ability to attract and retain business investment and professionally skilled labour and to sustain long-term economic growth is uncertain:

Ottawa is a city with many strengths. It is a well-established and economically successful city that is home to Canada's Federal Government, world-class businesses and internationally recognized universities. It draws on its rich history as a regional industrial centre and has carefully retained some important reminders of its long history, including numerous heritage buildings, a finely grained urban street grid, the Rideau Canal and many other artifacts of days as Uppertown and Lowertown. Situated on the banks of the Ottawa River, Ottawa is uniquely positioned as the bridge between two culturally different provinces, Ontario and Quebec, and greatly benefits from the contrasts and cultural diversity this locale offers. 
Today, there is no doubt that Ottawa as a city remains strong and economically successful. However, like all urban centres, if it is to remain a prosperous destination, Ottawa cannot rely on its past history to provide for the future. It must move forward and evolve, responding to changing urban realities. The Strategy recognizes that there are many challenges that Ottawa needs to address if it is to remain competitive and desirable as a place to live, visit and do business (City of Ottawa 2004e, p.9).

Remaining an 'economically successful city' in this new competitive terrain is presented as a key urban policy priority for the City of Ottawa and a challenge to which planning, and the City's urban design strategy, has been mobilized to respond.

In keeping with the Official Plan, the DOUDS stresses the importance of capitalizing on Ottawa's shifting housing market to intensify, repopulate and revitalize Ottawa's downtown environment as part of an effort to secure Ottawa's economic future:

Many cities and towns across the country are experiencing a renaissance in city centre living. Driven by changing lifestyles and a demand for the conveniences of city centre amenities, downtown living has become a very welcome new reality for cities. Ottawa needs to capture this opportunity by anticipating, preparing and responding to this demand at a scale that matches the opportunity (City of Ottawa 2004e, p.10, emphasis added).

While the DOUDS builds on the City's early intensification efforts to repopulate and revitalize Ottawa's downtown core through policies intended to stimulate new high-density residential development, it is a much more comprehensive strategy that places a premium on high quality urban design as an essential feature of a physically and economically revitalized downtown. In the Strategy, urban design includes the architectural quality of new residential and commercial development with special attention to both building and site design and landscaping, but also goes considerably beyond this to focus on the 'quality of the public realm and urban environment' in Ottawa's downtown, including such areas as streets, parks and open spaces, 
waterways, and cultural heritage features. The DOUDS advances a view that a city's economic competitiveness depends significantly on the quality of its downtown public realm and urban environment. A downtown's urban environment and public spaces, it argues, 'strongly affect one's perception of a city and significantly contributes towards nurturing a positive or negative 'feeling' of how vibrant, successful and desirable a city is as a place to live, work or play' (ibid, p.6). The role of urban design in the revitalization of Ottawa's downtown is most clearly explicated in the DOUDS vision statement:

Over the next 20 years, the Downtown Ottawa Urban Design Strategy 20/20 will help set the stage for a renewed physical environment for the downtown that is beautiful, inspiring and gracious. It will celebrate Ottawa's rich local history, integrating it with the City's unique role as Canada's National Capital. The downtown will become an enhanced focal point for the city and an even more distinctive destination for residents and visitors alike. It will be a sought after location for residential re-urbanization. Downtown Ottawa will enjoy a strong civic identity that is vibrant, livable and engaging. The impressive urban qualities of the downtown core will be seamlessly integrated across its local, citywide and national functions (City of Ottawa 2004e, p.3).

The strategy stresses the key role of urban design in transforming downtown Ottawa into an urban space that not only encourages residential living, but also 'safeguards, expands and diversifies the [downtown's] retail sector', 'creates usable, accessible and safe urban open spaces', 'preserves local built heritage' and 'celebrates the unique function of Ottawa as the Capital' (ibid, p.13), all in an effort to bolster the city's economic competitiveness and secure long-term growth.

The DOUDS divides Ottawa's downtown area into distinct 'precincts' based on their unique features and functions and provides area-wide and precinct-specific design plans and policies to build 'design excellence' into new private sector residential and commercial development and public realm 'enhancements' in the downtown. Area-wide strategies are described as large-scale strategic projects focused on streetscape infrastructure; urban parks, 
forests, and open space; as well as public art and design that, once realized, 'will impact on the image and experience of the downtown as a whole' (ibid, p.23 emphasis added). The DOUDS' preoccupation with image and place-making is an exemplar of urban policy transformations associated with the rise of the 'entrepreneurial city' (Brenner and Theodore 2002; Kipfer and Keil 2002). As an entrepreneurial city strategy, the objective of the DOUDS is to transform the city's downtown into a friendly, vibrant, livable and aesthetically appealing place that is attractive to business investment, residents and tourists. Downtown streetscapes, parks, urban forests and public art are discursively presented as strategic economic assets in the City's competitive quest to transform Ottawa's downtown image and market the city region as a desirable place to live, work and invest. The following excerpts concerning downtown streetscapes, parks and forests make explicit the privileging of economic competitiveness in the DOUDS approach to urban and environmental design in the public realm:

In successful cities, street are much more than traffic arteries. They become important street addresses for real estate, locations for cafes and public art and the thoroughfares for walking and biking in the downtown area. Many of Ottawa's downtown streets are overly focused on the movement of cars to and through the core and requires a better balance to make them remarkable urban places. ... When real estate development is looking for an address with urban curb appeal, these highly trafficked locations are often overlooked. This is especially true for residential projects (City of Ottawa 2004e, p.26).

The presence of green spaces and the quality of the urban forest contributes strong to the lasting impression of a city. This is especially true in the most urban areas of a city. Parks and open spaces are important for helping to attract new investment, adding value to existing buildings and bringing new residents to an area. They function as vital neighbourhood amenities and support a diversity of formal and informal recreational uses ... Green spaces and a healthy urban forest help to soften the hard character of city spaces, add beauty to urban settings, and improve environmental quality. Providing a number of small formal and informal spaces across a downtown area enhances the quality of its public realm and diversifies the experience of any downtown (ibid p.28).

In keeping with this 'entrepreneurial city' ethos, private and municipal investments in downtown 
public spaces and environments are intended to serve the interests of capital in-so-far as high quality and aesthetically beautiful public realm amenities enhance the 'image' and 'experience' of the downtown, creating urban spaces worthy of new investment.

At the precinct scale, improving urban design through public realm enhancements is explicitly tied to City efforts to 're-image', 're-theme', and 're-brand' particular downtown areas to attract business investment, tourism and new residents (City of Ottawa 2004e). Precinct strategies recommend 'plans of action' with regard to appropriate built form and scale, streetscape infrastructure requirements and parks and open space provision, but also identify very specific design issues associated with new private sector-led residential and commercial development (including building form and heights, heritage conservation, landscaping, parking and building views). The Downtown West Precinct, for example, is identified as having significant potential for intensification in the form of medium and high rise mixed use development on the 65 hectare Lebreton Flats and the former Ottawa Technical High School sites. The goal of the precinct strategy is to establish urban and environmental design guidelines for new high-density development and to identify opportunities to enhance the area's urban environmental features and public realm amenities in order to 'raise the profile of this peripheral edge area and re-image it as a desirable residential address' (ibid, p.33). According to the precinct strategy:

The Downtown West Precinct will play an important role in expanding the downtown area westwards and into the area below the escarpment. The availability of land, as well as the precinct's proximity to downtown, established neighbourhoods and the scenic Ottawa River makes the Downtown West Precinct an ideal location for residential-led intensification. Due to the precinct's natural topography and the existing nature of the built form (primarily high rise), new development could potentially be taller than in many other downtown precincts. ...

Emerging trends for downtown living, coupled with the precinct's desirable geographic location have created a renewed interest in this area for new residential development. 
Consequently, it is important that the City have a clear idea of the long-term vision for the precinct and what its development options are (ibid, p.34).

Noteworthy here is the prominence of the precinct's natural environmental features, including the Ottawa River and the escarpment, in the Downtown West's strategy to re-image the precinct as a 'desirable' place to live, work and invest. The plan for the precinct highlights the creation of a new park and network of open spaces along the escarpment that bisects the Downtown West area. The escarpment is described as a 'wonderful natural feature of downtown Ottawa that [currently] lies hidden beneath overgrowth and locked into an inefficient road network' (ibid, p.35). The strategy proposed to downsize and realign the existing transportation routes and introduce significant public realm improvements to 'reclaim the escarpment as a community asset and a destination feature of the downtown that exploits the site's natural topography' (ibid). Once completed, Escarpment Park is expected to bridge Ottawa's downtown (on the upper part of the escarpment) to the new residential and commercial development (as well as the new Canadian War Museum) planned for LeBreton Flats, consolidating the image of the precinct as an attractive and desirable downtown neighbourhood.

Following the adoption of the DOUDS by City Council in 2004, the City's Planning Department developed a series of city-wide urban design guidelines targeting specific urban environments and types of development, including Urban Design Guidelines for Development Along Traditional Mainstreets (2006a), Urban Design Guidelines for Development Along Arterial Mainstreets (2006b), Transit-Oriented Design Guidelines (2007), and Urban Design Guidelines for High-Rise Housing (2009a). While they address specific sets of urban and environmental design issues, the City of Ottawa's diverse guidelines have been strongly influenced by the DOUDS and reflect the City's preoccupation with urban revitalization as a 
strategy to attract new investment. During the same period, the City established an Urban Design Review Panel consisting of ten 'expert design professionals' with expertise in urban planning, building architecture, landscape architecture, green development technologies, and heritage conservation, to review proposals for new residential and commercial development in 'design priority areas'. Interestingly, the City's design priority areas directly correspond to areas targeted for significant intensification and redevelopment in the Official Plan - Ottawa's downtown precinct (as defined by the DOUDS), traditional and arterial mainstreets, mixed use centres and other areas identified as having special design needs (including mainstreets in rural villages). In 2005, the City created an Urban Design Awards program to 'celebrate projects built in the City of Ottawa that exhibit urban design excellence' (City of Ottawa, no date).

While few would argue against efforts to improve access to urban parks and open spaces, enhance streetscapes to make them more attractive and pedestrian-friendly, and encourage new residential development in downtown environments in order to reduce development pressures at the city's edge, the City of Ottawa's narrow focus on the more aesthetic qualities of urban enviornmental design over other, potentially more progressive, planning priorities has proved highly problematic. As a City-led, expert-driven process, Ottawa's urban design agenda constitutes a distinctly 'entrepreneurial city' strategy concerned, ultimately, with stimulating design-oriented urban intensification and revitalization in order to bolster the city's competitiveness on a regional and global scale. The City's preoccupations with design not only reflects the narrow planning priorities of city officials, planners and other expert professionals, but has also served to narrow the political terrain on which the City's intensification and revitalization strategies might be debated (and contested), and alternative urban environmental planning priorities considered, through more deliberative, community-based planning processes. 


\section{Conclusion}

Debates about regional sprawl have dominated urban politics in Ottawa for nearly two decades, perhaps longer. At the beginning of the $21^{\text {st }}$ century, in the wake of intense political economic restructuring at the federal and provincial level, the City of Ottawa advanced a new 'sustainability' agenda as the centerpiece of its new Official Plan. Although presented to the public as a comprehensive planning effort to curb regional sprawl, promote more environmentally-sensitive and sustainable land use planning and development practices, and create a more compact and 'livable' city region, this chapter builds on recent UPE scholarship to develop the argument that the City of Ottawa's 'smart growth'-inspired urban environmental policy agenda and planning framework - and the kind of socioecological transformation they imply - have been deeply implicated in the rolling out of a new wave of neoliberal urbanization across the city region (see, for example, Bunce 2004; While et al. 2004, Gibbs and Krueger 2007).

Without diminishing the efforts of municipal planners and officials to put 'the environment' on the City's policy and planning agenda, Ottawa's 'smart growth' strategy and intensification policies have hinged on the strategic and selective incorporation of environmental goals that appear ultimately concerned with securing Ottawa's long-term economic competitiveness, eclipsing issues of social and environmental justice central to more progressive interpretations of urban environmental 'sustainability' (Haughton 1999; Gibbs and Krueger 2007; McCann 2007). On one hand, the City's support for smart growth intensification has been premised on reining in growth-related spending in the aftermath of federal and provincial restructuring and the downloading of responsibilities for key infrastructure and services to cashstrapped local governments. At the same time, the City's intensification policies have been 
mobilized as part of an effort to stimulate new high density, mixed urban development practices in Ottawa's downtown and along mainstreets in neighbouring residential and commercial districts as part of a spatially targeted urban environmental remake on the understanding that knowledge economy investment and labour are attracted to cities that are socially and environmentally 'livable'. Policies geared toward, on the one hand, the protection of the region's rural landscapes, open spaces and its natural environments from the perils of sprawl and, on the hand, the physical and economic revitalization of Ottawa's urban core appear as much concerned with cultivating an image of Ottawa as an eminently 'livable' and sustainable' city to prospective investors and talent than with securing the long-term ecological integrity of these urban-natural systems. The extent to which the City's smart growth planning framework will reduce development pressures in Ottawa's periphery and encourage more compact, pedestrian and transit-oriented urban development remains to be seen.

An equally important, if not more pressing, question for this investigator concerns the implications of Ottawa's smart growth intensification strategy for social equity in the city, particularly as it relates to access to affordable housing. Although higher density mixed use urban development has the potential to support the creation of neighbourhoods that are more pedestrian and transit-oriented and offer a greater mix of housing types and tenures, including affordable rental and ownership housing, the City's intensification strategy, to date, has privileged the goals of economic competitiveness over social investment and redistribution in its policy orientation and development practices. Not unexpectedly, this raises difficult questions, discussed in the next chapter, concerning Ottawa's urban environmental policy agenda and the extent to which intensification may prove to 'intensify' existing social inequalities in Ottawa. 


\section{Chapter Seven}

Intensifying Inequality?:

Smart growth intensification as 'policy-led' gentrification in Ottawa's inner urban area

The City of Ottawa's 2003 Official Plan marked a significant shift in urban environmental governance and policy in the city region. 'Smart growth', premised on reining in regional 'sprawl' through the intensification of new residential and commercial development in Ottawa's existing built landscape was associated with the emergence of a new 'environmentally sensitive' and 'sustainable' approach to urban and regional planning introduced by the Province of Ontario and subsequently taken up by municipalities since 2001 . However, as I argue in Chapter 6 , the urban socioecological transformation implied by this policy change, has been deeply implicated in the rolling forward of a new wave of capitalist urbanization designed to enable the City of Ottawa, and municipalities across Ontario, to negotiate the complex governance dilemmas associated with the advance of neoliberalization, including both heightened levels of political economic uncertainty that have accompanied provincial-municipal restructuring and the rescaling of government responsibilities and the demands of the new knowledge economy. As an urban environmental policy, smart growth has been championed as a means to control growth related spending on municipal infrastructure and services, protect Ottawa's rural landscapes and natural environments particularly for their recreational and amenity value, while, simultaneously, stimulating the physical and economic revitalization of its downtown environments, as part of in an effort to create a more socially 'livable', environmentally 'sustainable' and 'economically competitive' city region (City of Ottawa 2003). Informed by recent critical theorizing of 'sustainability', the degree to which this shift in urban environmental governance and policy works within, rather than against, current processes of urban neoliberalization, raises troubling 
questions about the potential implications, for social (in)equity and (in)justice, of the City's 'smart growth' intensification polices and development practices.

In the two decades since the Brundtland Commission's report, Our Common Future (WCED 1987), the tensions between economic growth and environmental stewardship have been at the heart of public and political debates surrounding 'sustainable development', with comparatively less attention directed to the social inequalities and injustices wrought by capitalist development processes (Haughton 1999). Although social equity is often taken to be intrinsic to ideas of 'sustainability' - defined, post-Brundtland, by the balancing of economic growth, environmental stewardship and social equity goals - the relative failure of sustainable development discourses and policy development processes to mount a serious challenge to the fundamentals of capitalism has produced a swell of recent academic scholarship surrounding both the troubling silence on questions of equity in sustainable development debates and the very real potential for 'sustainable development' policies and interventions to perpetuate, even create new, patterns of social and environmental injustice (for example, see Marcuse 1998; Haughton 1999; Raco 2005; Gunder 2006; Gibbs and Krueger 2007; Jonas and While 2007).

In the arena of urban policy, Marcuse $(1998, p .103)$ observes that '[s]ustainability and social justice do not necessarily go hand in hand', '[p]rogrammes and policies can be sustainable and socially just but, unfortunately, they can also be sustainable and unjust'. Sustainability, Marcuse argues, is a 'trap'; the language of 'sustainable urban development' suggests that all humanity has a shared interest in 'sustainability', 'that if we all simply recognized our common interests everything would be fine, we could end poverty, exploitation, segregation, inadequate housing, congestion, ugliness, abandonment, and homelessness' (ibid, p.104-105). Yet, under 
contemporary forms of capitalism, urban development and housing are inherently 'conflict ridden arenas' - 'what benefits one hurts another' (ibid, p.105).

The rise of neoliberal modes of urban governance since the early 1990s brings this argument into sharp relief. In the aftermath of political economic restructuring by senior levels of government in Canada, as elsewhere, local governments now shoulder new financial responsibilities for the provision of affordable housing, public transit, and other municipal infrastructure and services without commensurate revenue streams to meet these new obligations. Cities have, in response, shifted towards more entrepreneurial and competitive styles of governance, focused on attracting business investment and improving their ability to compete in a globalized, knowledge-based economy. In cities in Canada, as elsewhere, this has entailed a shift towards a 'growth first' approach to urban development that prioritizes inner city revitalization over social investment and redistribution (Mayer 2007; also see Swyngedouw 2002; Weber 2002). As Weber (2002, p.190) explains, '[d]evolution increased cities' dependence on own-source revenues, namely property tax revenues, which in turn made them more dependent on those that create value: the private real estate market'. According to Ward and Jonas (2004, p.2121), this shift in governance and policy, defined by its preoccupation with economic competitiveness and growth, has involved a corresponding retreat from 'issues of redistribution, conflict, counterstrategies, and politics'. They argue that 'given the emphasis on exchange relations and strategic competition, corresponding attention to the social relations of production, consumption, and redistribution and their underlying geographies of conflict are, at best, limited' (ibid). As discussed in the previous chapter, policies aimed at promoting 'sustainability' have become central features of this shift in urban governance and policy, 
suggesting that 'sustainability' appears complicit in the reproduction of inequality and injustice in contemporary urban environments.

Drawing on recent critical scholarship that elaborates the connections between urban intensification, revitalization and gentrification processes, this chapter explores the implications of Ottawa's new urban environmental governance regime and smart growth intensification policies for social (in)equity in the city, with particular attention to the issue of housing affordability. Although the City of Ottawa espouses smart growth intensification as an urban environmental policy with the potential to improve housing affordability and social inclusion at the neighbourhood scale and across the city region, this chapter advances the argument that as the City shifts towards a more entrepreneurial governmentality, in a period of intense neoliberal restructuring, the City's policy of revitalization through intensification takes a 'growth first' approach to urban development that prioritizes the physical and economic revitalization of Ottawa's city centre over concerns of social investment and redistribution. The absence of strong and enforceable policies that require the inclusion of new affordable housing units geared to low and middle income residents and families into new high density residential development, I argue, constitutes a missed opportunity on the part of the City of Ottawa to begin to address, however modestly, the City's affordable housing crisis and promote more socially equitable and inclusive patterns of urban intensification. As it is currently conceptualized and implemented, evidence suggests that the City of Ottawa's unwavering and enthusiastic support for market-driven, upscale condominium development represents a form of 'third wave' or 'policy-led' gentrification with the potential to intensify, rather than ameliorate, existing inequalities in Ottawa's housing system and to diminish, not enhance, the 'livability' and 'sustainability' of the city region. As Haughton 1999, p.234) so poignantly observes, this matters because 'the unjust 
society is unlikely to be sustainable in environmental or economic terms in the long run'. Without first addressing the crisis of housing affordability, and the political economic roots of inequality in all its forms, there is little hope of redressing the unsustainable crisis of sprawl and building more socially equitable and ecologically sustainable urban landscapes.

\section{Urban intensification, neighbourhood revitalization, and 'third wave' gentrification}

Over the last few decades, cities in North America and Europe have begun to experience the adverse effects of decentralization and suburbanization processes. By the early $1990 \mathrm{~s}$, in Ottawa, this translated into a policy built around the promotion of urban revitalization through a strategy of urban intensification to reverse the depopulation and decline of the city's downtown core. A decade later, a policy of revitalization through intensification became the centerpiece of a much larger and, arguably, more ambitious 'smart growth' planning agenda in the City of Ottawa's new Official Plan. In the Official Plan, support for high-density residential development in Ottawa's city centre advances the City's interests in urban revitalization but is, simultaneously, (re-)presented as a land use strategy to curb regional sprawl and promote more environmentally 'sustainable' patterns of urban development in the city. Smart growth urban intensification in the new Official Plan highlights what Bromley et al. (2005, p.2407) describe as 'the intertwined goals of regeneration and sustainability' in contemporary urban policy and planning.

Recent critical scholarship on urban revitalization in North American and European cities highlights this uneasy convergence among discourses of urban revitalization ('regeneration', and 'reurbanziation') and sustainability vis-à-vis recent urban environmental governance and policy change (Smith 2002; Lees 2003, 2008; Bromley et al. 2005; Bunce 2006, 2009; Quastel 2009). In Britain, for example, Lees (2003) observes that the Labour government's urban revitalization 
campaign of the late 1990s drew significantly on the discourse of urban sustainability, wherein urban intensification was presented as a strategy with the potential to promote, simultaneously, the goals of urban sustainability and city centre revitalization. Labour's revitalization strategy called for a reduction in suburban, automobile-oriented development patterns and a corresponding intensification of inner urban housing development intended to draw Britain's middle class 'back to the city' (ibid, p.61). According to Lees (ibid, p.75), in Labour's vision of urban revitalization, sustainability takes the form of an 'environmentally sustainable urban renaissance' achieved through the intensification of city centre development. Bromley et al. (2005, p. 2407-2408) observe that the redevelopment urban brownfield sites, the adaptive reuse of offices or warehouses to support high density mixed use development in city centres, and targets requiring that new housing development be directed to 'urban' land, were among the policies supported by the British government to realize its vision of an 'urban renaissance'.

In a Canadian context, Bunce (2005, p.180) explains that Toronto's Official Plan likewise espouses a view of urban intensification as strategy to protect Toronto's regional environment from the effects of continued low-density regional sprawl while, at the same time, enabling city officials 'to justify and support a market-driven economic and physical revitalization plan for Toronto's central city'. Cloaked in the language of 'sustainability', Bunce argues that 'the environmental problems of regional sprawl serve as a public rationale for the primary municipal goal of increasing Toronto's economic and land-use development through private-sector investment and the attraction of skilled labour to the city' (ibid). In Toronto's Official Plan, support for high density, mixed use development is presented as a strategy 'to enhance the livability and vibrancy of the downtown' by creating 'flexible living/work spaces' that encourage 'pedestrian access and close proximity to services, places of employment, home, and other 
residents' (ibid, p.185), on the understanding that business investment and professionally skilled labour are attracted to city centres that are economically vibrant and socially livable.

As urban revitalization and sustainability become cornerstones of new urban policy and planning agendas in different parts of the world, recent scholarship points to a troublesome association between urban intensification and gentrification practices in cities (Hackworth and Smith 2001; Smith 2002; Bromley et al. 2005; Davidson and Lees 2005; Bunce 2009; Lehrer and Wieditz 2009; Quastel 2009). Contemporary gentrification is a complex urban process that defies any single definition as it now occurs at a variety of sites and scales, involves an array of possible actors, and takes many different forms. Hackworth and Smith (2001), however, distinguish contemporary 'third wave' gentrification from earlier gentrification processes in several ways. Temporally, the authors date the emergence of third wave or 'post-recession' gentrification to the early 1990 s. Unlike earlier waves of gentrification in the $1980 \mathrm{~s}$, the authors suggest that 'third wave' gentrification is driven more by economic forces than by cultural factors as 'the scale of investment is greater and the level of corporate, as opposed to smallerscale capital, has grown' (ibid, p.468).

According to Smith (2002), the geographies of gentrification have changed dramatically over the last two decades. In an era of globalization, Smith argues that gentrification has become a 'global urban strategy' (ibid, p.437). Not only has gentrification spread laterally to world cities across the globe, it has also spread vertically along the urban hierarchy, evident in smaller cities and towns in different regions of the world. Although highly varied and unevenly distributed, Smith argues that gentrification practices share common features and 'connect in many complicated ways to wider national and global political economies' (ibid, p.439). Davidson and Lees $(2005$, p.1167) go so far as to argue that, in a very real sense, 'a "gentrification blueprint" is 
being mass-produced, mass-marketed, and mass-consumed around the world'. As the geographies of gentrification become increasingly globalized, so too are the geographies of gentrification expanding outward beyond the city centre (Hackworth and Smith 2001; Smith 2002). Though by no means a 'smooth and regular process', Smith (2002, p.442) explains that as gentrification in inner city neighbourhoods produces an escalation in land and housing prices, urban districts beyond the core 'become caught up in the momentum of gentrification'. The outward expansion of gentrification to neighboring districts, he argues, is highly variable, 'influenced by everything from architecture and parks to the presence of water. Above all, it is geared to the historical patterns of capital investment and disinvestment in the landscape' (ibid).

The actors driving gentrification have also changed. Third wave gentrification is defined as a largely state-led (or 'policy-led') process wherein local governments actively court private sector real-estate developers in urban development practices (Hackworth and Smith 2001). For Smith (2002, p.443), what distinguishes third wave gentrification from earlier processes is that "a new amalgam of corporate and state powers and practices has been forged in a much more ambitious effort to gentrify the city'. In a context of globalization and political-economic restructuring, Smith asserts that gentrification has become a defining feature of contemporary neoliberal urbanization - 'a systematic, comprehensive policy for city building' (Smith 2008, p.196) led by municipal governments in partnership with private capital. Specifically, he argues:

Retaking the city for the middle classes involves a lot more than simply providing gentrified housing. Third-wave gentrification has evolved into a vehicle for transforming whole areas into new landscape complexes that pioneer a comprehensive class-inflected urban remake. These new landscape complexes now integrate housing with shopping, restaurants, cultural facilities, open space, employment opportunities - whole new complexes of recreation, consumption, production and pleasure as well as residence. Just as important, gentrification as urban strategy weaves global financial markets together with large- and medium-sized real-estate developers, local merchants, and property agents with brand-name retailers, all lubricated by city and local governments for whom 
benefit social outcomes are now assumed to derive from the market rather than from its regulation. Most crucially, real-estate development becomes a centerpiece of the city's productive economy, and end in itself, justified by appeals to jobs, taxes, and tourism. In ways that could hardly be envisaged in the $1960 \mathrm{~s}$, the construction of new gentrification complexes in central cities across the world has become an increasingly unassailable capital accumulation strategy for competing urban economies (ibid, p.443, emphasis in original).

Building on these contributions to the growing body of literature on gentrification, recent scholarly work, in and beyond the field of urban political ecology, goes an important step further by drawing critical attention to the ways in which discourses of 'nature', 'environment' and 'sustainability' have become actively incorporated in contemporary 'third wave' or 'policy-led' gentrification practices (Smith 2002; Lees 2003, 2008; Bunce 2004, 2009; Bromley et al. 2005; Quastel 2009). As discussed in the previous chapter, the shift towards increasingly competitive and entrepreneurial modes of urban governance has given rise to new urban environmental policy and planning regimes geared toward promoting city centre intensification and revitalization on the understanding that economically 'vibrant', socially 'livable' and environmentally 'sustainable' urban landscapes enhance urban competitiveness in a globalized, knowledge-based economy. Although the language of 'sustainability' and 'livability' suggests a progressive moment in urban policy and planning, in practice, urban intensification and revitalization policies in cities across the world are being implemented in close partnership with private real-estate developers for whom new upscale, high density residential and 'mixed use' development, targeting relatively affluent young urban professionals and retired empty-nesters, constitutes an aggressive capital accumulation strategy.

Framed within the legitimating language of sustainability and livability, contemporary policy-led gentrification has a powerful depoliticizing effect. Whereas earlier waves of gentrification were marked by significant public opposition in light of concerns about the social 
dislocations and inequities wrought by gentrification practices, recent scholarship argues that urban intensification, championed by city officials and planners as an environmentally sustainable alternative to regional sprawl, has diminished political opposition to urban revitalization and regeneration strategies (Smith 2002; Lees 2003, 2008, Bunce 2004, 2009). In relation to policy-led gentrification policies, Lees (2008) observes:

It is a policy language that never uses the word gentrification and thus consistently deflects criticism and resistance. Terms like urban renaissance, urban revitalization, urban regeneration and urban sustainability are used instead, avoiding the class constitution of the processes involved and neutralizing the negative image that the process of gentrification brings with it' (Lees 2008, p.2452, emphasis added).

In his discussion of British regeneration policies in the late 1990s, which promoted urban intensification and brownfield redevelopment as a remedy to suburban sprawl, Smith (2002, p.445) argues, for example, that 'enveloped as regeneration, gentrification is recast as a positive and necessary environmental strategy'. Bunce $(2009 ;$ p.656) elaborates a similar argument when she observes that " $[\mathrm{t}]$ he use of ostensibly positive and "holistic" terms such as sustainability and regeneration dampens critiques of, and active resistance to, the effects of policy-led gentrification, such as policies that support middle to upper income-oriented property development instead of affordable housing'.

Against concerns about the potentially detrimental effects of gentrification on lowincome populations, recent scholarship observes that urban intensification and revitalization programs in cities across North America and Europe increasingly rely on the current policy rhetoric of 'social balance', 'social mixing' and 'inclusive neighbourhoods' to suggest that revitalization/gentrification can enhance the 'livability' of depressed neighbourhoods (Lees 2003, 2008; Rose 2004; Blomley 2004). As Rose argues: 
[S]ince the image of the 'liveable city' has become a key aspect of a city's ability to compete in a globalized, knowledge-based economy (Florida 2003), postindustrial cities have a growing interest in marketing themselves as being built on a foundation of 'inclusive' neighbourhoods capable of harmoniously supporting a blend of incomes, cultures, age groups and 'lifestyles'. This may include targeting young and highly mobile one-person households working in 'new economy' occupations ... or promoting 'family friendliness'.... In contexts of scarcity of affordable housing, the principle of social mix may be invoked in order to remedy the situation through infill or adaptive reuse, or at least to maintain part of the existing stock. Here the pragmatic need to house 'key workers' near the urban core may meld with the desire to control the most extreme and visible forms of socio-spatial polarization, which diminish a city's 'liveability' image (Rose 2004, p.281).

More and more, urban intensification and revitalization policies advance a view of social mixing (and gentrification) - that is, attracting middle-income people to low income districts - as 'a good thing', arguing that socially mixed and inclusive neighbourhoods produce social and economic benefits that 'trickle down' to lower income residents (Lees 2008, p. 2451). In Canada, for example, where local governments are highly dependent on property taxes as a source of revenue, urban intensification and revitalization policies aimed at attracting middle class residents back to the city are advocated as a means to boost the property tax base and support municipal reinvestment in infrastructure and amenities in downtown neighbourhoods. Other arguments in favour of social mixing concern the relative political power of middle class people to advocate for pubic reinvestment in their neighbourhoods and the benefits of socially mixed neighbourhoods for stimulating local economic activity and jobs (Rose 2004; Lees 2008). In "Three Cheers for Gentrification", for example, Andres Duany, champion of the American Smart Growth/New Urbanism movement, describes gentrification as 'the rising tide that lifts all boats' to the extent that it 'rebalances a concentration of poverty by providing the tax base, rub-off work ethic, and political effectiveness of a middle class, and in the process improves the quality of life for all of a community's residents' (Duany 2001, p.36). In this respect, as Lees (2008, 
p.2451) argues, gentrification emerges as a 'positive pubic policy tool' geared toward the revitalization of inner urban neighbourhoods. The effect of this discursive policy shift is to diminish, if not render altogether invisible, very real concerns about displacement and exclusion of low-income populations from gentrifying neighbourhoods.

Insights from this recent body of critical gentrification scholarship raise difficult questions about 'smart growth', 'new urbanist' and 'city regional' policy agendas. While newbuilt high density, mixed-use urban development (and redevelopment) has the potential to attract middle-class and more affluent residents back to the city, stimulating the physical and economic revitalization of city centres and their surrounding urban neighbourhoods and enhancing urban economic competitiveness, it also tends to result in the escalation of land and housing prices, driving gentrification and the potential displacement of low income residents from revitalized neighbourhoods. From this perspective, policies promoting 'sustainability' appear largely stripped of their potential redistributive content and directed instead towards the sole pursuit of 'sustaining' urban competitiveness and economic growth (Kipfer and Keil 2002; Dixon and Dupuis 2003; Gilbert 2004; Bunce 2004, 2009; McCann 2007). Although routinely framed in the language of 'sustainability' and 'triple-bottom line' decision-making, the argument developed here is that, in the absence of policies requiring that affordability be built into new high-density residential development, smart growth intensification appears to constitute a new wave of neoliberal urbanization in the City of Ottawa that may prove to intensify, rather than ameliorate, patterns of social inequality and exclusion and, in-so-doing, undermine long-term 'sustainability' in the city region. 


\section{Smart growth: revitalization through intensification}

The City of Ottawa's interest in residential intensification as an urban revitalization strategy dates back to the early 1990 s as a policy response to the large-scale depopulation and decline of the city's downtown over the preceding decades. The migration of families to Ottawa's suburbs from the early 1960 s onward precipitated the erosion of the city's downtown residential neighbourhoods. According to the Canada Mortgage and Housing Corporation (CMHC), 'many older residential properties in the downtown were converted to office space or allowed to deteriorate and were replaced by surface parking lots. High land values effectively eliminated housing investment except for upscale condominium development, which largely attracted singles' (CMHC 2003, p.1). In the early 1990s, a school closure in Ottawa's downtown led municipal officials to fear that other downtown schools and facilities catering to families would follow (ibid). In 1990, the Planning Department of the former Regional Municipality of OttawaCarleton produced a discussion paper, Opportunities for Residential Intensification in OttawaCarleton (1990), in which planners argued the advantages of a shift in urban policy in favour of residential intensification, 'the foremost being its ability to upgrade existing properties and revitalize surrounding neighbourhoods' (Regional Municipality of Ottawa-Carleton 1990, p.1). The potential for intensification to 'slow the need to provide additional services to newly developed areas' in Ottawa's fast growing suburbs, to 'provide a higher municipal tax base' and, thereby, and to reduce annual property tax increases were also noted (ibid). Higher density residential development was also considered, at the time, as having the potential to contribute to the provision of affordable private sector housing in the Ottawa's downtown.

The City launched the Residential Downtown Intensification (Re-Do-It) Initiative in 1994, to help reverse the deterioration of residential neighbourhoods and to 'revitalize' the city's 
downtown districts. To stimulate new residential development in downtown neighbourhoods, the program included a waiver on development charges and a reduction in building permit fees as incentives to stimulate new residential development in target areas of the downtown core. According to the $\mathrm{CMHC}$, the repeal of development charges, coupled with improved market conditions, 'brought about a revival of Ottawa's downtown housing market in the mid-1990s' (CMHC 2003, p.3). More than thirty housing projects were initiated between 1994 and 1997, for a total of 1,773 new units in Ottawa's downtown. Approximately half of these new developments were townhouses located on infill sites or produced through the conversion of non-residential buildings (ibid).

A new downtown revitalization program was launched in 1999 , by then mayor Jim Watson. The short-term provisions of the plan included several planning and development fee exemptions designed to stimulate residential development in the downtown core. All downtown commercial and residential development was exempted from payment of building permits and planning application fees; residential developments of fifty units or less were exempted from the five per cent parkland levy in the downtown (with the exception of the Lebreton Flats area); and, the development charge exemption associated with the former Re-Do-It program was continued as part of this new initiative (ibid).

In January 2001, following the amalgamation of the former lower tier municipalities of the Ottawa region into one mega-city, the new City of Ottawa approved a new Downtown Action Plan which included the same range of incentives but extended the waiving of the residential cash-in-lieu of parkland levy to developments of more than fifty units in order to stimulate the development of larger scale residential projects (ibid). The geographical area where development incentives were offered was also expanded to target a much larger area in the city's downtown 
core. By 2003, when the City of Ottawa adopted its new Official Plan, the City's intensification policy to support new residential (re)development in Ottawa's downtown created over 6,000 new residential units and the City was triumphant that 'redevelopment opportunities for growth in the downtown area still abound' (City of Ottawa 2004d, p.1).

Building on the momentum of the City's previous intensification policy, urban intensification became a defining feature of the Official Plan's 'smart growth' agenda. The City's new policy of urban intensification was geographically expanded beyond the downtown core, reconceptualized and re-presented to the public as a city regional approach. In a departure from the City's intensification strategy of the 1990s, which presented a narrower view of intensification as a policy instrument to reverse the depopulation and decline of Ottawa's downtown core through an aggressive strategy to stimulate new high density residential development, under the umbrella of 'smart growth', urban intensification and revitalization took on new meaning - discursively re-branded in the legitimating language of urban environmental 'sustainability'.

The Official Plan's broad definition of urban environmental sustainability, as it has been translated and adopted into the City's 'smart growth' planning policies and development practices, takes the form of high- density mixed-use residential and commercial districts in Ottawa's existing built landscape. The intensification of new residential and commercial development in Ottawa's urban core is presented, simultaneously, as a strategy to save Ottawa's rural landscapes and natural environments from the perils of low-density suburban sprawl, create more 'vibrant', 'compact' and 'complete' mixed use urban neighbourhoods and, ultimately, to build a more 'sustainable' and 'livable' city region (City of Ottawa 2003, p.16).

As part of a broad urban revitalization strategy, municipal support for private sector-led 
intensification, in coordination with public and private investment in high quality urban environmental design and public realm amenities - including pedestrian-friendly streets, urban forests, parks and open spaces, public art, cultural heritage features and recreational amenities has been geared toward attracting middle class residents back to the city centre. Intensification is presented by the City of Ottawa, and marketed by private sector real estate developers, as an opportunity for residents to live closer to places of work, retail, entertainment, recreation and other lifestyle amenities, making walking, cycling and public transit viable alternatives to private automobiles in the everyday lives of urban residents. Capitalizing on a growing market interest in 'downtown living', particularly among retiring baby boomers and young urban professionals, intensification becomes a vehicle for stimulating the physical and economic revitalization of Ottawa's city centre.

According to the Official Plan, the benefits of urban revitalization extend beyond the downtown to the entire city region. Borrowing from Richard Florida's (2002) creative city handbook, the Plan takes the position that the physical and economic revitalization of Ottawa's urban core not only helps to attract and sustain a vibrant mix of residential, retail and commercial activity, it enhances Ottawa's image as a 'livable' and 'sustainable' city region, and so, its ability to attract knowledge economy investment and professionally skilled labour in an era of intense inter-urban competition. In this respect, intensification, revitalization and sustainability are presented in the Official Plan as mutually reinforcing policy goals.

The integration of sustainability objectives into the City of Ottawa's smart growth planning framework and its intensification and revitalization policies, immediately raises questions about how sustainability policies are translated and 'taken up' in private sector urban development practices. Recent scholarly work explores how urban sustainability policies have been made to 
serve market-oriented private property development in cities (Tallon and Bromley 2004; Bromley et al. 2005; Raco 2005; Bunce 2009). Recent contributions to the literature on gentrification go further to examine the role of public sector urban sustainability policies in legitimating private sector-led urban development and gentrification practices, producing new patterns of displacement and exclusion in the urban built environment (Lees 2003; Davidson and Lees 2005; Larsen 2005; Bunce 2009; Lehrer and Weiditz 2009; Quastel 2009). In the following section, I examine how the City's of Ottawa's 'smart growth' intensification policies have shaped, and are being shaped by, market-oriented development practices in Ottawa's downtown and surrounding mature urban neighbourhoods. Although the vast majority of high density urban development built since the adoption of the Official Plan has not directly caused the displacement of low-income residents, there is early evidence to suggest that as the image, attractiveness and desirability of neighbourhoods undergoing intensification increase, rising housing prices constitute a form of 'exclusionary displacement' (Davidson and Lees 2005, p.1170) in which low income, and even middle class, residents and families are increasingly unable to secure housing because of the gentrification of the neighbourhood.

\section{Intensification and the gentrification of urban neighbourhoods in Ottawa's urban core}

In the Official Plan and more recent City Housing Strategy (2007), the City's policy of urban intensification was presented as an opportunity to build affordable housing development into the City's urban revitalization program. Housing affordability and housing choice are identified as pressing public policy issues that, left unaddressed, had the potential to accelerate regional sprawl and exacerbate housing insecurity in Ottawa over the Plan's twenty-year planning horizon. By 2000, demand for affordable housing in Ottawa was on the rise, particularly among 
low-income households, following nearly a half-decade of intense provincial-municipal restructuring in the Province of Ontario. Between 1995 and 2000, the Ontario Conservative government deregulated Ontario's rental housing market and downloaded social housing costs and administrative responsibilities to Ontario municipalities without new funding streams to enable cities to invest in new affordable housing development. The effect of this restriction in the supply of affordable housing was compounded by the simultaneous growth in demand for affordable housing units in the wake of declining welfare payments and other cuts to social support services imposed by the Ontario government during the same period. Record level inmigration during the peak of Ottawa's high tech boom in the late 1990s had placed new pressure on Ottawa's already limited rental housing stock:

The shortage of rental housing is one of the most compelling problems today in Ottawa. People now on long waiting lists for subsidized housing are being squeezed by low vacancy rates and rental costs that are steadily rising further beyond their means. Even families with moderate incomes have difficulty finding affordable ownership and rental housing.

The lack of choice in many housing markets is an on-going issue. Although 40 percent of Ottawa's households rent their housing, only 5 percent of the housing constructed between 1996 and 2001 were rental units. Housing that is already in short supply in the city may be further constrained in the future. Conversions from rental to ownership would tighten an undersupplied rental market. Demolition of affordable housing when new development occurs is also an emerging issue. All housing is potentially threatened by aging and lack of repair (City of Ottawa, 2003a, p.47).

According to the City Housing Strategy (2007, p.11), rental housing is a vital part of the city's housing stock because if offers tenants, who comprise forty percent of Ottawa households, relatively stable access to housing. Yet, despite the significance of rental housing to Ottawa's economically vulnerable populations, the City reports that, since 1996, only six percent of housing completions in Ottawa have been rental dwellings, while the remaining ninety-four 
percent has been ownership housing (ibid, p.10). Moreover, Ottawa was losing affordable rental housing at an alarming rate. According to a report by the City of Ottawa's Community and Protective Services Committee, over two thousand rental units have been lost from Ottawa's housing system since 1995 (City of Ottawa 2007f, p.2).

Both the Official Plan and the more recent City Housing Strategy (2007) identify social equity - in terms of access to appropriate and affordable housing - as a cornerstone of a sustainable and livable city. Both documents argue that policy efforts to curb regional sprawl and promote higher density, mixed use urban development in Ottawa's existing built environment are intended, among other things, to support the creation of more 'socially diverse' and 'inclusive' neighbourhoods in Ottawa's urban core. As the City Housing Strategy explains:

Housing is also the fundamental building block of healthy, inclusive, sustainable communities. Socially diverse and culturally vibrant communities are more easily fostered with a diversity of housing options. More compact, denser housing development can minimize impacts on the environment by making more efficient use of land, reducing traffic congestion and improving air quality. Community prosperity is improved when all community members have access to affordable, appropriate housing from which they can engage in the local economy. All of this promotes the long-term sustainable health of our communities. (City of Ottawa 2007, p.1)

Given limited private sector rental housing development over the preceding decade and the recent downloading of social housing costs and administrative responsibilities to Ontario municipalities in the late 1990s, the City's 'smart growth' intensification strategy was presented and sold to the public as, among other things, an opportunity to address the severe shortage of affordable housing across the city region. According to the City's Housing Strategy (2007, p.10), high-density urban development supports the creation of more diverse housing types and tenures: '[d]enser housing types such as townhouses and apartments, typically with smaller unit sizes, are usually more affordably priced' when compared to low density single-detached dwellings 
common to most modern suburban developments.

While intensification is presented as an opportunity to encourage the development of new affordable housing units, the City of Ottawa was also acutely aware that support for compact urban development, in the absence of strong and enforceable policies to ensure affordability, had the potential to erode housing affordability, intensify gentrification and the (direct or indirect) displacement of low income residents from neighbourhoods undergoing intensification, and, ultimately, perpetuate regional sprawl. As the City Housing Strategy explains:

Many municipalities have begun to realize that policies on compact development and intensification can lead to rising land values and the loss or exclusion of affordable housing during the (re)development process. This contradicts good urban planning and the promotion of diverse, inclusive neighbourhoods by excluding lower income households and potentially forcing people to move further outside the urban core in search of more affordable housing (City of Ottawa 2007, p.42).

In the Official Plan, the City establishes targets for the inclusion of affordable housing units in all new residential development to ensure that future high-density residential development supports, rather than undermines, housing affordability in Ottawa's urban core. In the Plan, affordable housing is defined as 'housing, either ownership or rental, for which low- or moderate-income households pay no more than 30 percent of its gross annual income' (City of Ottawa 2003, p.48). The City set a target requiring that twenty-five percent of new housing units in all development projects will be affordable housing, of which 15 percent are to be targeted to households up to the $30^{\text {th }}$ income percentile (with an annual household income up to $\$ 45,068$ ) and the remainder of the 25 percent targeted to households up to the $40^{\text {th }}$ income percentile (with an annual household income up to $\$ 57,763$ ) (ibid; also see City of Ottawa 2007) ${ }^{5}$. The Official Plan's affordability targets, however, do not account for household size. As a consequence, small

\footnotetext{
${ }^{5}$ Income percentiles reflect 2007 calculations as presented in the City Housing Strategy (2007).
} 
bachelor condominium apartments produced through intensification may meet the Official Plan's definition of affordability, yet fail satisfy the basic housing requirements of low income families.

Although the Official Plan's intensification mandate supporting a shift towards higher density residential development in Ottawa's city centre and surrounding inner urban area was expected to encourage housing affordability through the production of smaller, denser dwelling units, the Official Plan identifies a number of policies, incentives and regulatory tools available to the City to encourage the creation of new affordable units within new private sector residential developments as part of the City's development approvals process. Under Ontario's Planning Act, for example, cities have legislative authority to offer developers financial incentives such as grants, property tax relief, and exemption from development charges on developments projects that include an agreed upon number of affordable units.

Density incentives, or 'density bonusing', are another tool available to municipalities to build affordability into new high-density residential development in the private housing market. Section 37 of Ontario's Planning Act contains policies that permit municipalities to enter into agreements with private sector residential developers wherein, in exchange for increased building height or density that surpasses an existing zoning by-law, developers are required to provide a benefit to the community as negotiated by the municipality. As part of the City of Ottawa's smart growth intensification strategy, Section 37 agreements are identified as an opportunity for the municipality to capture a share of the added value that may result from the increase in density or height of a development project and to pass this 'benefit' along to the local neighborhood in which the new development is located. In the Official Plan, increases in density or height may be permitted in return for the provision of public or community amenities that include, but are not limited to, public cultural facilities, building design and public art, 
conservation or replacement of rental housing, provision of new affordable housing units, child care facilities and improvements to local transit stations (City of Ottawa, 2003, p.155). While affordable housing is one of many possible public benefits that could be secured through Section 37 agreements, the Official Plan highlights the application of density incentives for building affordable housing units into new high density development projects in neighbourhoods undergoing significant intensification (ibid, p.48).

Why then has the City's policy of urban intensification, to date, done little to advance the production of high density, affordable housing in Ottawa locations targeted for large-scale intensification? The remainder of this section will demonstrate that the City's intensification policies, in practice, have been closely aligned with market-oriented urban development practices in Ottawa's city centre wherein profit maximization has trumped concerns about the creation of affordable housing and socially inclusive urban development. Under the City's policy of urban intensification, medium and high-rise condominium development, catering to the consumer demands of middle class and more affluent young professionals and retired baby boomers, is stimulating a new wave of gentrification, radically transforming the built and social landscape of the city's urban core.

Ottawa's condominium boom: a new market for high-density urban development

At the beginning of the $21^{\text {st }}$ century, Ottawa's housing situation was quite precarious given recent waves of political economic restructuring in the Province of Ontario and the explosive growth of Ottawa's high technology sector that resulted in record-level in-migration to Ottawa, intensifying demand for housing in the city. At the height of Ottawa's high tech boom in the late 1990s, migration to Ottawa produced an unprecedented demand for housing. In 1999-2000, 
Ottawa attracted 12,500 new immigrants, second only to Toronto in the province of Ontario (CMHC 2002a, p.7). High demand for housing and a tight supply of resale homes in the Ottawa region resulted in skyrocketing housing prices across the city region while also driving down rental vacancy rates to historic lows. In 1995, the average price for a home in Ottawa was $\$ 140,534$. By 2001 , the average home price was $\$ 175,971$ and in 2002 had reached $\$ 200,711-$ an increase of 14.1 percent in just one year (CMHC 2003b, p.2). During the same period, Ottawa experienced a very tight rental market. In 2001, Ottawa's rental vacancy rate was just under one percent, leading to a significant escalation in rents across the city region (CMHC 2002b, p.2). Rising rental costs and home purchase prices translated into reduced housing affordability across the Ottawa region (Table 7.1).

Table 7.1 Average home prices in Ottawa, 1995-2002

\begin{tabular}{|l|l|}
\hline Year & Average Home Price \\
\hline 1995 & $\$ 140,534$ \\
\hline 2001 & $\$ 175,971$ \\
\hline 2002 & $\$ 200,711$ \\
\hline
\end{tabular}

Source: CMHC, Ottawa.

Given a high demand for housing, the new homes market in Ottawa experienced a boom in 2001 , recording the highest number of housing starts in more than a decade (CMHC 2002a, p.3). While the development of new single-family housing occurred throughout the region, the vast majority was concentrated in Ottawa's suburban communities of Nepean, Kanata and Orléans. Central Ottawa had the lowest number of new single-family starts, but the highest number of 
multi-family starts than any other part of the city region (CMHC 2002b, p.2). Noteworthy here is that amidst a very tight housing market, the city began to show signs of an emerging market trend towards higher density residential development, particularly in the form of townhouses and medium and high rise condominium development, in Ottawa's downtown and in the city's 'mature' neighbourhoods immediately outside the downtown core - a shift that was stimulated, in part, by the City's own downtown intensification policy in the latter half of the 1990 s.

Prior to 2001, the city's condominium market was limited. The number of existing condominium apartments in the entire City of Ottawa was estimated to be no more than 17,250 units, just under five percent of the city's entire housing stock (CMHC 2002a, p.4). Growing market interest in condominiums at the beginning of the $21^{\text {st }}$ century was being driven by key demographic and lifestyle changes in the city. In Ottawa, as in other cities across Canada, household sizes were in steady decline. Ottawa's population was also aging, as baby boomers were reaching middle age and becoming a powerful influence on Ottawa's housing market. At the same time, the City of Ottawa's housing projections identified a 'noticeable resurgence of interest in urban lifestyles', characterized by higher density residential living in mixed use neighbourhoods that allow residents to live and work in the same area and to 'function on foot' to satisfy most of their daily needs locally (City of Ottawa 2007a, p.35). Ottawa's dense city core and its mature inner suburbs were identified as 'best position[ed] to provide this lifestyle option since they already possess the amenities sought by people seeking an urban lifestyle'. By the early 2000s, demand for condominiums, particularly in these inner urban districts, was on the rise as retirees and empty-nesters looked to live nearer to central services and amenities and young urban professionals were attracted to trendy downtown residential locations that allow them to live in closer proximity to places of work, recreation, entertainment, and other urban 
lifestyle amenities (City of Ottawa 2007, p.35). Given skyrocketing housing prices in the wake of Ottawa's high tech boom, demand for condominiums and townhouses also emerged as a more affordable and attractive housing option, particularly among first-time homebuyers.

In 2002, the pace of new housing construction in the Ottawa region was the highest it had been in more than a decade and for the first time Ottawa's multi-family housing market, particularly condominium and townhouse development, outpaced single-family housing starts (CMHC 2002b, p.5). In 2002, multi-family starts in Ottawa reached 3,996 units, representing an increase of 35 percent from the previous year. In the condo market, specifically, construction in 2002 was the highest it had been since the 1980 s, as dwindling supply in the resale market translated into a spike in new condominium development. By the end of 2002, total condo starts grew to 747 units, a considerable increase from the 285 new units built in 2001.

In terms of housing prices, the condo market was particularly 'hot' in 2002 , as the average price for a condominium soared by over 20 percent to end 2002 at around $\$ 156,100$ (CMHC $2003 \mathrm{a}, \mathrm{p} .5)$. By 2003 , average condo prices grew by an additional 13 percent to $\$ 162,000$, boasting the highest price gains of all housing types in Ottawa (CMHC 2003b, p.3). Notably, at the same time that condominiums showed the highest price gains in Ottawa, overall housing prices in Ottawa's downtown, where housing demand far exceeded supply (and where the vast majority of new condominium development was located), reached historic highs, from a total average MLS resale price of $\$ 211,169$ in 2000 to over $\$ 270,000$ by the end of 2002 (CMHC $2002 \mathrm{~b}, \mathrm{p} .5)$. In 2003 , the downtown had the highest housing prices of anywhere in the city, where they grew by just under 10 percent to settle at a resale average price of $\$ 306,800$ by the end of that year (CMHC 2003b, p.6) (Table 7.2). 
Table 7.2 Average home prices in downtown Ottawa, 2000-2003

\begin{tabular}{|l|l|}
\hline Year & Average Home Price \\
\hline 2000 & $\$ 211,169$ \\
\hline 2002 & $\$ 270,000$ \\
\hline 2003 & $\$ 306,800$ \\
\hline
\end{tabular}

Source: CMHC, Ottawa.

In the new Official Plan, the City sought to capitalize on this shift in Ottawa's housing market towards higher density residential living to pursue an aggressive, market-driven intensification strategy focused on condominium and townhouse development in Ottawa's downtown and surrounding mature urban neighbourhoods. In step with policy transformations at the federal and provincial levels requiring a shift to more compact urban development patterns, the City's smart growth intensification campaign drew significantly, and strategically, on the language of 'urban sustainability' and 'revitalization' to sell its vision of a physically and economically revitalized downtown and a more socially livable and environmentally sustainable city region.

Urban intensification: leveraging market interest in high-density urban development In the Official Plan, the geographies of urban intensification suggest that public sector 'sustainability' policies have, in practice, been closely aligned with market-oriented private sector urban development practices in Ottawa. Although the City's policy of urban intensification, in the new Official Plan, is geographically expanded beyond the downtown, reconceptualized and re-presented as a city regional approach, new high-density residential 
development would not be evenly distributed across the city region, but rather concentrated in 'designated growth areas'. Areas designated for intensification in the Official Plan include Ottawa's downtown, traditional mainstreets, mixed-use districts, and areas close to public transit stations in the city's inner urban area as well as (though to a far lesser degree) in 'towncentres' and employment and enterprise zones in the city's more distant suburbs.

Specifically, in the Official Plan, areas targeted for intensification are those identified as having 'significant development potential' (City of Ottawa, 2003a, p.19). In the City's Residential Land Strategy for Ottawa, 2006-2031, 'development potential' is defined in part by the availability of vacant urban land to accommodate new infill development and the potential for redevelopment of existing properties, but also, and perhaps more significantly, by the 'market readiness' of particular urban locations across the city region to embrace higher-density forms of residential development (City of Ottawa 2009b, p. 33). In its Residential Land Strategy, developed as part of Ottawa's five-year Official Plan Review (OPR), the City examined the 'market readiness' of particular locations to accommodate high-density residential and commercial development as part of an exercise to develop intensification and minimum density $\operatorname{targets}^{6}$ for different parts of the city region, as required by Ontario's 2005 Provincial Policy Statement. Beyond the downtown, the Preston, West Wellington, and Richmond traditional mainstreets immediately west of the downtown, Bank Street and Bronson Avenue to the south, Main Street east of the downtown, and key locations in the vicinity of rapid transit stations (such as Tunney's Pasture) near the urban core are among the locations identified as having an existing (or emerging) market for new high density residential (and commercial) development and as

\footnotetext{
${ }^{6}$ The City of Ottawa's intensification targets are measured in new dwelling units built in a target location between 2006 and 2031. Density targets are expressed in terms of people and jobs per gross hectare in a target area over the same time (City of Ottawa 2009a).
} 
locations 'already embraced by the housing market as desirable places to live' (City of Ottawa 2009b, p.42). Rapid transit stations along the city's future light rail rapid transit line, larger arterial roads (such as Merivale Road and St. Laurent Blvd.), and suburban towncentres outside Ottawa's greenbelt, do not yet have a market for high density urban development, though they are expected increase in density as part of City's long term projections.

Intensification and density targets established by municipal planners, and approved by Ottawa City Council in the 2009 Official Plan Amendment (City of Ottawa 2009c, p.2-13), directly correspond to the perceived 'market readiness' of different locations in (or in close proximity to) Ottawa's urban core, providing evidence of the close alignment between the City's policy of urban intensification and market-driven, private sector inner city residential development. In the Residential Land Strategy, the largest urban area slated for future intensification is Ottawa's downtown with a target of 4500 new residential units between 2006 and 2021 and 7850 units by the year $2031^{7}$ (City of Ottawa 2009b, p.40). The vast majority of future high-density development targeted for Ottawa mainstreets is to be concentrated in locations in or in close proximity to the downtown and where the city's condominium market is already well established. 2031 intensification targets for Richmond, Bank, and West Willington mainstreets and along arterial mainstreets like Montreal Road, St. Joseph Boulevard, and Carling Avenue, while considerably lower than Ottawa's downtown districts, demonstrate the City's faith that Ottawa's mainstreets offer 'some of the most significant development opportunities in the city for intensification' (ibid, p.41) (Table 7.3).

\footnotetext{
${ }^{7}$ The downtown intensification target includes the redevelopment of the Lebreton Flats along the eastern edge of Ottawa's downtown.
} 
Table 7.3 Intensification Targets for Traditional and Arterial Mainstreets (dwelling units)

\begin{tabular}{|l|c|c|c|c|c|}
\hline $\begin{array}{l}\text { Traditional } \\
\text { Mainstreet }\end{array}$ & $\begin{array}{c}\text { Short term } \\
\text { (by 2021) }\end{array}$ & $\begin{array}{c}\text { Mid term } \\
(2021-31)\end{array}$ & $\begin{array}{c}2031 \\
\text { Target }\end{array}$ & $\begin{array}{c}\text { Long term } \\
\text { (Post 2031) }\end{array}$ & TOTAL \\
\hline Richmond & 800 & 1000 & 1800 & 2350 & 4150 \\
\hline Bank & 1000 & 625 & 1625 & 100 & 1725 \\
\hline West Wellington & 675 & 550 & 1125 & 775 & 2000 \\
\hline Beechwood & 375 & 500 & 875 & 325 & 1200 \\
\hline Preston & 300 & 400 & 700 & 800 & 1500 \\
\hline Arterial Mainstreet & & & & & \\
\hline Montreal & 750 & 1500 & 2250 & 5375 & 7625 \\
\hline St. Joseph & 400 & 1600 & 2000 & 8700 & 10700 \\
\hline Carling & 500 & 1000 & 1500 & 8600 & 10,100 \\
\hline St. Laurent & 0 & 500 & 500 & 8400 & 8900 \\
\hline
\end{tabular}

Source: Residential Land Strategy, City of Ottawa (2009).

Likewise, the City's minimum density targets suggest that intensification, while conceptualized at the level of the city region in the Official Plan, is ostensibly an urban strategy focused on stimulating new private sector development in 'market-ready' locations in Ottawa's downtown and in nearby residential and commercial districts. The minimum density target established for Ottawa's downtown, for example, is 500 dwelling units per hectare. In mixed-use centres and transit nodes beyond the downtown, however, the City's minimum density targets decline considerably to 250 units per hectare in Tunney's Pasture, 200 units per hectare in Bayview-Preston, Confederation Heights and Hurdman, and to 120 units per hectare in the more suburban mixed-use centres of Billings Bridge, Cyrville, and Industrial Avenue. In suburban towncentres, where a market for high density development remains limited, the strategy requires a minimum density target ranging from ninety-seven units per hectare in Orléans towncentre to sixty-six units per hectare in Kanata towncentre, while in suburban greenfields the minimum density target is only thirty-two units per hectare (ibid, p.61) (Table 7.4). 
Table 7.4 2031 Density targets for the Central Area and Mixed Use*

\begin{tabular}{|l|c|c|}
\hline Area & $\begin{array}{c}\text { Density Target } \\
(2031)\end{array}$ & $\begin{array}{c}\text { Density Target } \\
\text { (Post-2031) }\end{array}$ \\
\hline Central Area (downtown) & 500 & \\
\hline Major Mixed Use Centres (MUC) & & \\
\hline Tunney's - Quad & 250 & \\
\hline Lees & 250 & \\
\hline & & \\
\hline MUC at Key Transfer Stations & & \\
\hline Bayview-Preston & 200 & \\
\hline Confederation Heights & & 200 \\
\hline Hurdman & & 200 \\
\hline & & \\
\hline Emerging MUC & & \\
\hline Billings Bridge & 120 & \\
\hline Industrial & & \\
\hline Cyrville & 120 & \\
\hline & & \\
\hline Suburban Towncentres & & \\
\hline Orleans TC & 97 & \\
\hline Kanata TC & 66 & \\
\hline
\end{tabular}

* Density targets expressed as People and Jobs per Gross Hectare.

Source: Residential Land Strategy, City of Ottawa, 2009b.

Reducing barriers to private sector-led high density urban development

City planners and officials also examined opportunities to actively facilitate market-oriented high-density residential development in Ottawa's urban core. Following the adoption of the Official Plan, the City maintained its policy of waiving development charges on high density residential development in Ottawa's downtown (a carry-over from the previous intensification strategy) to offset the high costs of urban land that can serve as a barrier or disincentive to city centre development.

In 2007, the City of Ottawa also adopted a Brownfields Redevelopment Community Improvement Plan, that offered private sector property developers financial incentives to encourage the remediation, rehabilitation and redevelopment of urban brownfields as part of an 
effort to facilitate intensification and promote sound 'environmental stewardship' in Ottawa's downtown and neighbouring residential and commercial districts (City of Ottawa 2007c). In the Brownfields Plan, brownfields are defined as 'abandoned, vacant, or underutilized commercial and industrial properties where past actions have resulted in actual or perceived environmental contamination and/or derelict or deteriorated buildings' (ibid, p.1). According to the City, brownfields can result in reduced property values, economic activity and employment in locations where the City is actively seeking to promote renewed re-investment and revitalization. The redevelopment of brownfields is presented as an economic opportunity to remediate environmentally contaminated or derelict properties, encourage urban intensification, and promote the revitalization of city centre environments. Given the technical complexities and financial and liability risks that act as barriers to brownfield redevelopment, the Brownfields Plan includes a range of financial incentives to Ottawa's development industry - including municipal loans and grants, tax-increment equivalent financing, waiver of municipal fees and development charges, use of environmental liability insurance and programs for public education and community participation - to facilitate the environmental remediation and redevelopment of brownfield properties in support of the City's intensification, revitalization and sustainability policy goals.

During the City's Official Plan review process, the City established an Intensification Implementation Group (IIG) with a mandate to explore opportunities to reduce regulatory barriers to intensification in Ottawa's urban core. The IIG's mission is to identify barriers to intensification that exist within the City of Ottawa's current policies, practices and development standards and to engage Ottawa's private sector development industry and other stakeholders (such as Ottawa Hydro, other utilities, and school boards) with the 'ultimate aim to remove as 
many barriers to intensification as possible while maintaining the highest standards in community design, safety and good planning' (City of Ottawa 2009d, p.1). In a City report entitled Barriers to Intensification: Conversations with Industry (2009d), private sector developers identify zoning as the most significant regulatory barrier to intensification across the city region. Zoning was introduced to Ottawa in 1964 at a time when the goal of urban planning was to reduce urban densities and reinforce land use separation. A new Comprehensive City of Ottawa Zoning By-law was adopted in 2008 that harmonizes the previous 36 zoning by-laws from the former municipalities into one by-law and brings zoning provisions more into line with the City Official Plan. Although the new Comprehensive Zoning By-law implements many of the policies of the City's 2003 Official Plan, city planners and developers share a view that existing zoning regulations and performance standards, particularly those concerning building height, impede intensification.

Since the adoption of the 2003 Official Plan, 'upzoning' has become a common feature of the development review and approvals process in the City. Private sector developers routinely seek to have a property rezoned to permit development at building heights that exceed the existing zoning bylaw. While developers mobilize the language of 'environment', 'sustainability', and 'smart growth' and cite the City's own intensification policies to support upzoning applications, upzoning (or 'spot rezoning') has drawn considerable public contestation among residents living in neighbourhoods targeted for intensification, often slowing the development approvals process. To address concerns expressed by Ottawa's private sector development industry, the Residential Land Strategy identifies the rezoning of intensification target areas as a future policy priority to ensure that zoning accommodates building heights and densities consistent with the Official Plan's new intensification and density targets (City of 
Ottawa 2009b, p.55). Revised zoning regulations, coupled with the City's new intensification and density targets, are to be used to guide the development of Community Design Plans in neighbourhoods where significant intensification is expected to occur, to build 'certainty' into (and silence community resistance during) intensification planning and expedite the development approvals process, facilitating rather than hindering new high density residential development.

Quite crucially, the City justifies public policy support for market-driven, high-density urban development practices in Ottawa's inner urban built environment by appeal to changing demographics and lifestyle preferences, particularly those of Ottawa's more affluent young professionals and aging empty-nesters and retirees driving Ottawa's condo market. As the City explains, '[t]he market demands it ... therefore it gets built. Smaller households, an aging population, and the increasing appeal of the urban lifestyle support expectations of higher levels of apartment construction' (City of Ottawa 2007, 33). The implication appears to be that municipal officials and planners have little choice but to embrace and support current housing market trends and the lifestyle preferences of the city's more affluent demographics.

More broadly, municipal support for high-density private sector-led development is framed in the language of city centre 'revitalization', 'sustainability' and 'livability'. According to the Residential Land Strategy, 'The City wishes to leverage the market's interest in urban living to rejuvenate, revitalize and repopulate older areas of the city that would provide opportunities for more people to live in environments where walking, cycling and transit are viable alternatives to the car' (City of Ottawa 2009b, p.26, emphasis added). In step with arguments of policy-led gentrification, a careful reading of the Residential Land Strategy suggests an emerging 'partnership' between the City's policy of urban intensification and the market-driven private property agendas of Ottawa's residential development industry - a partnership that is justified on 
an understanding that the repopulation and revitalization of Ottawa's city centre through high density condominium development is key to 'environmentally-sensitive' planning and 'sustainable' urban growth across the city region. Yet, the partnership between public policy and private property development in the implementation of urban intensification quite clearly privileges the housing and lifestyle aspirations of the City's more affluent resident populations suggesting a close relationship between urban intensification and gentrification practices.

Urban intensification and the gentrification of Ottawa's urban core: implications for housing affordability

Since the adoption of the Official Plan in 2003, the City's policy of revitalization through intensification has actively facilitated market-driven urban development practices favouring high-density residential development in Ottawa's downtown and surrounding, mature inner urban neighbourhoods. Although originally conceptualized as a city regional approach in the City's Official Plan, over the last several years, the lion's share of urban intensification - 97 percent, in fact - has occurred inside Ottawa's greenbelt, with comparatively less higher density development in the city's outlying suburban areas (City of Ottawa 2008, p.15). City-supported urban intensification has occurred mostly through residential infill and the demolition and redevelopment of existing properties (including brownfields) to accommodate medium and highrise condominium and townhouse development in the city's urban core.

The explosion of new condominium development has dramatically transformed the socioecological landscape of Ottawa's city centre. Signs of capital reinvestment, both by private sector real estate development firms building the properties and the buyers of new condominium units, are everywhere, from Ottawa's Byward Market, Centretown and Preston (Little Italy) neighbourhoods in the city's downtown, to the mainstreets of Ottawa's mature, inner (sub)urban 
neighbourhoods, including Westboro village and Hintonburg east of the downtown, the Glebe and Old Ottawa South to the south, and Sandy Hill, Old Ottawa East and Vanier, just east of the downtown core. Likewise, as part of the City's Downtown Ottawa Urban Design Strategy (DOUDS), new upscale condominium development has gone hand-in-hand with renewed public investment in urban infrastructure and amenities - including new and/or upgraded community and recreation centers, public park and open space 'enhancements', landscaping and streetscaping improvements - all geared toward enhancing the 'beauty', 'attractiveness' and 'livability' of downtown neighbourhoods (City of Ottawa 2004e).

Prior to the condominium boom that began in the late $1990 \mathrm{~s}$, many of these neighbourhoods were in a situation of disinvestment and decline following decades of lowdensity suburbanization in communities outside Ottawa's greenbelt. Capitalizing on a renewed market interest in high density residential living in Ottawa's urban core, the City of Ottawa's policy of urban intensification actively facilitated a new wave of private sector reinvestment, mostly in the form of upscale medium and high rise condominium development, in Ottawa's city centre. The argument developed here is that these new-build residential developments seem an anathema to the Official Plan's vision of 'smart growth' and the creation of more equitable, inclusive, and sustainable patterns of urban development. Quite the contrary, the City's revitalization through intensification strategy appears illustrative of Hackworth and Smith's (2001) idea of 'third wave' gentrification to the extent that it has unfolded through a strategic partnership between private sector capital and local government policy, framed within the legitimating language of urban 'revitalization', 'sustainability' and 'livability'.

In Ottawa's downtown, thirty-seven, mostly upscale, medium and high-rise condominium developments were built or in the pipeline by 2008. A similar pace of luxury 
condominium development is occurring in Ottawa's Westboro Village, a mature suburban neighbourhood located just east of downtown, along the Ottawa River. Driven by both large and smaller 'boutique' style development firms, the vast majority of this new-build development is located on or within a block of a traditional mainstreet as developers seek out attractive, central locations and take advantage of opportunities to blend new medium and high-rise residential development with ground-floor (typically upscale) retail and other commercial business (Figure 7.1).

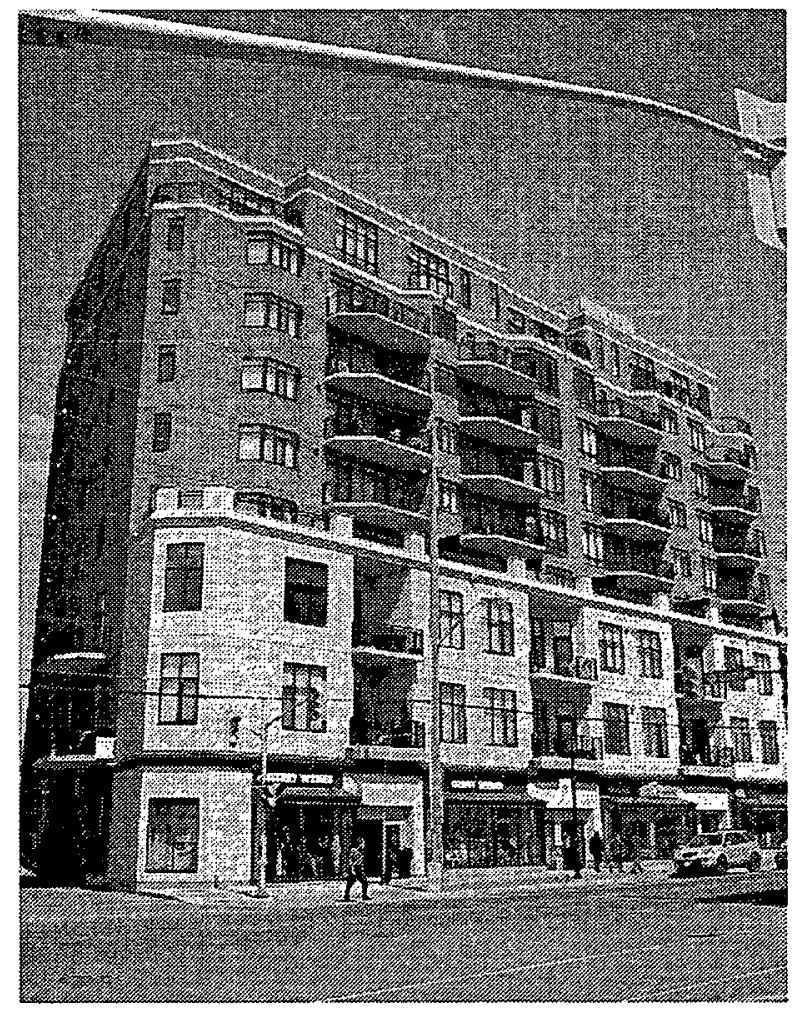

Figure 7.1 The Exchange, Domicile Developments. A nine-storey upscale condominium development with ground level retail in the heart of Westboro Village. Source: Photo taken by the author on July 20, 2010.

Acutely aware of market trends, private sector residential development firms, such as Ascroft, Charlesfort, Claridge, Domicile, Urban Capital, Ubanetics, Minto, and Teron Developments have 
built and are marketing new condominium developments to cater to the urban lifestyles of affluent young urban professionals and aging empty-nesters attracted to urban locations in close proximity to urban amenities and services. In Westboro Village, for example, Domicile's internet-based marketing strategy is premised on selling accessibility to urban lifestyles and amenities complete with interactive maps highlighting all of the local restaurants, entertainment, upscale retail and niche boutiques, health food and grocery stores, local farmers' markets as well as bike paths, parks, rivers and beaches that neighbourhoods have to offer prospective buyers. In its marketing materials for OneThreeOne, an eight story upscale condominium development currently under construction on Wellington Street West in Westboro is described by the 'boutique builder' as 'a blending of neighbourhood energy as hip and blossoming Hintonburg collides with the family-friendly, locally owned businesses and restaurants of Wellington Village. And don't forget Parkdale Market, where year round fresh products are yours for the picking' (Domicile 2011). This marketing strategy is clearly geared to attracting young professionals drawn to urban lifestyles and 'trendy' urban neighbourhoods.

A number of savvy developers also draw explicitly on the vision and language of 'urban sustainability' and 'smart growth' to negotiate City approval of new condominium developments while also selling a vision of urban living geared to attracting Ottawa's middle class and more affluent residents back to the city. The marketing slogan for Westboro Station, an upscale midrise, mixed use condominium development atop ground floor retail and office space, is 'live shop work', which plays with the idea of mixed use urban development and flexible 'live-work' environments as exemplar of 'smart growth'. In Ottawa's downtown, Charlesfort Development's marketing campaign for a new high rise condominium complex, called Hudson Park, included a billboard erected along Ottawa's Queensway, a highway connecting suburban residents to 
downtown jobs, asking drivers if they were 'Enjoying the Commute?' (Figure 7.2). Like the Westboro Station development, Charelesfort's marketing strategy suggests that developers are selling more than homes, they are selling a particular urban lifestyle in which professionals can live and work downtown, avoid unpleasant and polluting suburban commutes, and enjoy the accessibility to entertainment, retail and other amenities that city centre living has to offer. The implication is that a downtown living is more environmentally sustainable (and ethical) and socially livable, at least for those who can afford the price tag.

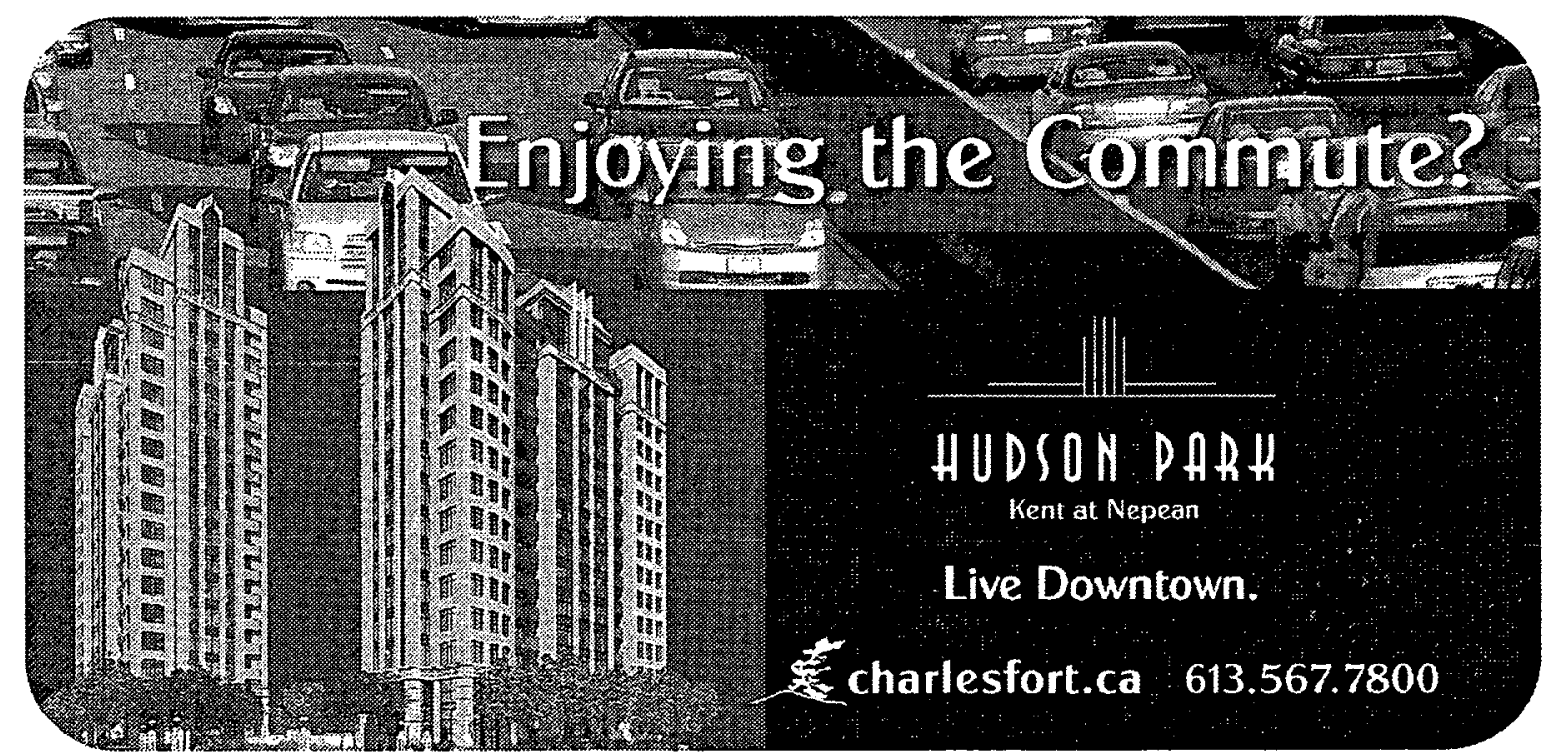

Figure 7.2 Promotional sign for Hudson Park condominium complex in downtown Ottawa. Source: Charlesfort Developments.

Private sector real estate developers in Ottawa are also beginning to incorporate environmental design features, particularly LEED specifications, into their development practices. Windmill Developments broke new ground in Ottawa with the development of The Currents, a 10-storey, mixed-use development that includes a 43-unit condominium tower and a theatre housing the Great Canadian Theatre Company (Figure 7.3). The Currents was one of the 
first projects in Canada to be awarded LEED Platinum certification. The property was an environmentally contaminated brownfield site - a former gas station and dry cleaner - that required environmental remediation prior to construction. The building pre-dated Ottawa's brownfield program by several years and helped to jump-start that discussion among City planners and the development industry. The City waived development fees for the project to recognize the 'public benefits' of environmental remediation and partnered with the development firm to raise funding from the Federation of Canadian Municipalities' Green Municipal Funds to support many of the development's 'sustainable design' innovations. In addition to its LEED

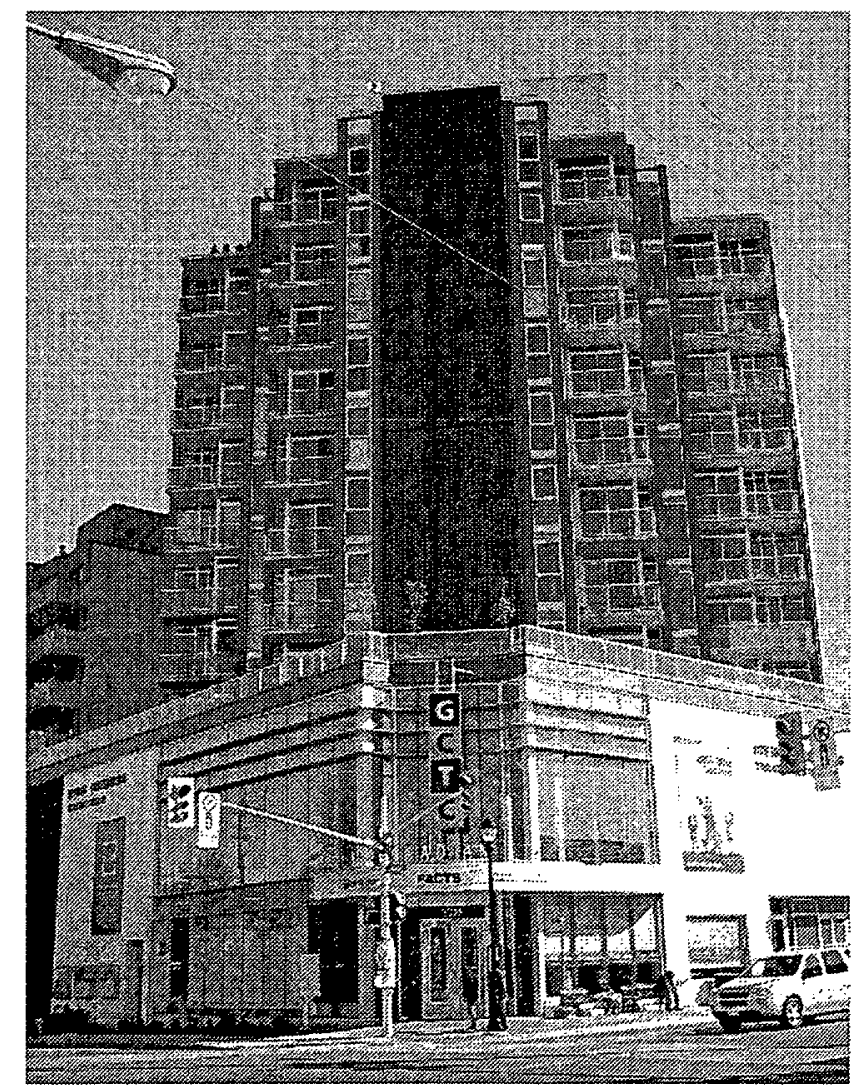

Figure 7.3 The Currents, Windmill Developments. The first LEED Platinum certified 'green' condominium in Ottawa, located in the gentrifying neighbourhood of Hintonburg. Source: Photo taken by the author on July 20, 2011. 
Platinum certification, the development boasts a prominent solar wall on the southern façade, 100 percent exhaust air heat recovery, rainwater capture used for flushing toilets, a highly energy-efficient building envelope and highly efficient building mechanical systems, low and zero VOC materials, rapidly renewable flooring materials, low-flow water fixtures and energy efficient appliances in all units.

Over the last several years, real estate development firms like Domicile, Urban Capital, EcoCité and Windmill Developments have built LEED certified, luxury condominium developments in different neighbourhoods across Ottawa's urban core, for which homebuyers pay a steep premium. The marketing of LEED certified condominium developments in Ottawa sells a vision of urban living that associates upscale, high-density residential development with broad notions of urban sustainability and environmentalism. The real estate firm EcoCité, for example, marketed its EcoCité on the Canal development arguing 'It is now possible to live in a home that will drastically reduce your impact on the environment and increase your standard of living.' In this 'uneven ethical space' (Quastel 2009, p.696), real estate developers attempt to reconcile, and simultaneously advance, environmental stewardship and wanton gentrification as compatible development goals with the full support of local government. In response to mounting interest in LEED certification among Ottawa's private sector development industry and more affluent condo buyers, for example, the City of Ottawa is in the process of developing a 'green pathway' LEED pilot program to encourage green building measures through design assistance and a separate 'green approvals process' to facilitate and expedite 'environmentallyfriendly' private sector residential and commercial development in the city.

Developers are typically reluctant to release information about the selling price of units in these new-build condominium developments, although there are a few exceptions. At the more 
'affordable' end of the spectrum, in the new OneThreeOne condominium development on Wellington West, a 657 square foot studio apartment is currently selling for $\$ 268,100$, while one bedroom units (with den) range from $\$ 312,800$ to $\$ 347,100$ and two bedroom units from 362,700 to $\$ 409,000$. Also on Wellington West, new condominium units in Westboro Station, Phase 3 range from $\$ 260,800$ to $\$ 795,900$. On the other end of the spectrum, the recently approved (not yet completed) Charlesfort development, The Merit, located in the heart of Ottawa's downtown (across from Ottawa City Hall), ranges between $\$ 861,000$ and $\$ 1,349,000$. Ottawa's resale market provides a broader picture of the type of condominium developments built through intensification since 2003 and how these developments are transforming not only the built but also the social landscape of Ottawa's inner urban neighbourhoods. In December 2011, the MLS resale price of condominium units in Ottawa's downtown ranged from $\$ 217,777$ and $\$ 1,690,000$. In Westboro Village the condominium resale market was comparable to the downtown, ranging between $\$ 243,514$ and $\$ 1,549,000$ for a condominium unit.

Measured against the Official Plan's targets for housing affordability in new-built development, the City's policy of urban intensification has, unfortunately, done little to advance the creation of new affordable housing units in Ottawa's urban core. In the City's Annual Development Reports, upscale condominium developments like Hudson Park, The Currents, and The Exchange figure prominently as examples of successful urban intensification, yet the same reports document the City's systemic failure, year after year, to come close to (much less achieve) its housing affordability targets. In 2005, for example, only 8.5 percent of new built condominium apartments were affordable to households at the $40^{\text {th }}$ income percentile (with an annual household income up to $\$ 57,763$ ) and only 1.1 percent were affordable to households at the $30^{\text {th }}$ percentile (an annual household income up to $\$ 45,068$ ) (City of Ottawa 2006c, p.28). By 
2008, affordability had deteriorated considerably due to rising housing prices and higher mortgage rates, with the result that none of the new built condominium developments completed that year were affordable to households at the $30^{\text {th }}$ income percentile (City of Ottawa 2009e, p.34). In 2010 , affordability of new built condominiums had not improved dramatically; at the 30th percentile (in 2010 , this represented a household income up to $\$ 48,581$ ), 1.1 percent of condominium completion was affordable, while 37.8 percent were affordable at the 40th percentile (with a household income up to $\$ 62,567$ in 2010 ) (City of Ottawa 2011, p.25). Despite these figures, according to the City's Annual Development Reports, condominium development represents the most 'affordable' home ownership option in the City of Ottawa today.

While new upscale condominium development may be 'affordable' relative to singlefamily detached dwellings in Ottawa's downtown and more distant suburbs, condominium units that meet the City's definition of affordability are primarily small bachelor and one-bedroom suites tailored to singles and childless couples. Given the small unit size of most new condominium apartments in Ottawa, condominium development does not offer affordable housing options to families looking to live downtown or in its surrounding urban neighbourhoods. As one housing activist in Ottawa described in an interview, these are 'small, costly units' that fail to address the housing needs of low-income families (Personal interview, January 9, 2008). Larger dwellings produced through intensification, either in medium and high rise condominium buildings or townhouses, that would offer suitable accommodation to low income and middle class families typically exceed the City's definition of affordability in Ottawa's inner urban neighbourhoods.

Moreover, the City's affordability targets for new private sector-led high-density development do not address the housing needs of the Ottawa's most economically vulnerable 
groups, those who are housing insecure and at risk of homelessness (households in the lowest income percentiles living below the poverty line). So, while new condominium apartments may be 'affordable' to Ottawa's middle class and more affluent singles and couples, it is not affordable to its lowest-income populations, most of whom are renters or living without stable shelter.

A lack of affordability as a result of high housing prices associated with new upscale condominium development has, unfortunately, been exacerbated by limited new rental housing construction in the City of Ottawa since the adoption of the Official Plan. In 2005, for example, there were only 343 private rental units completed in the city, compared to 4,320 newly built freehold dwellings (including single detached, semi-detached and row houses) and 1,097 condominium units (City of Ottawa 2006c, p.75). In 2008, the rental housing market had not improved, with fewer new rental units available (226 units) despite growth in freehold (5,078 units) and condominium (1,128 units) development (City of Ottawa 2009e, p.85). By 2010, the rental housing market had worsened still, with only 181 new rental units on the market, compared to 4,808 new built freehold and 1,431 condominium dwellings competed that year (City of Ottawa 2011, p.53).

Rental vacancy rates have somewhat improved in the last several years from a historic low of just under one percent in 2001 to 3.9 percent in 2004, although more recently, vacancy rates have again slipped down to 1.4 percent in 2008 and 1.6 percent by 2010 (ibid, p.56). Although average rents in the City have increased modestly (compared to other large Canadian cities) between 2003 and 2010, from $\$ 938$ to $\$ 1,048$ for an average two-bedroom apartment in Ottawa (ibid), rental increases have been more pronounced in Ottawa's urban core where demand is highest. According to a CMHC rental housing report, rental vacancies between 2008 
and 2010 have also been lower in Ottawa's downtown, and in the city's inner urban neighbourhoods such as Westboro, Hintonburg, the Glebe and Sandy Hill where intensification has contributed to the desirability of these locations in both the private rental and ownership housing markets (CMHC 2010, p.4). Even modest increases in rents, compounded by low vacancy rates, will intensify patterns of housing insecurity faced by Ottawa's over 40,000 renter households and the 10,520 households on Ottawa's social housing waiting list - the majority of whom earn less that $\$ 20,000$ per year and cannot afford rent of more than $\$ 500$ per month (Alliance to End Homelessness, 2010, p.8). Other than government subsidized social housing, which has been in sharp decline since senior government responsibilities for social housing programs were downloaded to municipalities, the private rental market constitutes the most affordable housing tenure for low-income households. Yet, the City of Ottawa has been largely unsuccessful in stimulating new (and truly affordable) private sector rental housing since the adoption of the Official Plan given the limited profitability of this type of development and, thus, a general disinterest among private sector real estate developers.

Private, non-profit, community-based housing organizations, such as the Centretown Citizens Ottawa Corporation (CCOC), which builds a mixture of rent-geared-to-income and market rental housing to maintain and promote housing for low and moderate-income residents, also face a particular uphill battle to build truly affordable rental housing, particularly in Ottawa's downtown today. Following the cancellation of social housing programs by the senior levels of government in the mid-1990s, non-profit housing developers have struggled to build and maintain affordable rental and ownership housing. The City of Ottawa's intensification and revitalization policies have compounded this situation. Escalating land and property prices mean that non-profit housing builders are 'priced out of the market', no longer able to afford to 
purchase and redevelop properties downtown. As one non-profit housing developer in Ottawa explains, '[o]ne of the downsides of the whole movement towards smart growth, which is to intensify and build up downtown, is that the value of the land is exponentially growing. ...We don't even look for it [land in the downtown] anymore' (Personal interview, January 17, 2008). If non-profit housing providers wish to build affordable housing in Ottawa's urban core today, they need to obtain City-owned land at little to no cost or find alternative, innovative ways to finance and build affordable housing.

CCOC's project to redevelop the Beaver Barracks, a former Royal Canadian Air Force military residence, offers a recent example of a non-profit housing development geared to providing affordable rental housing in Ottawa's downtown. The 254-unit new development includes three mid-rise apartment buildings (at 4,7 and 8 stories) as well as two and three bedroom townhouses that, together, offer diverse rental housing options suited to low and moderate-income singles, couples, families and seniors in the heart of Ottawa's downtown (Figure 7.4). As a housing expert involved in the Beaver Barracks redevelopment explains, ' $[t]$ he Beaver Barracks land was free, other than that there is no way that we can contemplate doing that [building affordable housing downtown]. We cannot pay for land, period' (Personal interview, January 17, 2008). Made possible by the donation of City-owned land, this type of development is a rare but relevant example of new high-density urban development that contributes to Ottawa's affordable rental housing stock. The Beaver Barracks also incorporates a number of sustainable design features, still rare among affordable housing developments in the City of Ottawa. A former brownfield site, the land was subject to full environmental remediation and the new residential buildings offer a geo-exchange system for heating and cooling (lowering energy costs of tenants), a green roof system and a tenant-led community garden on the property. 


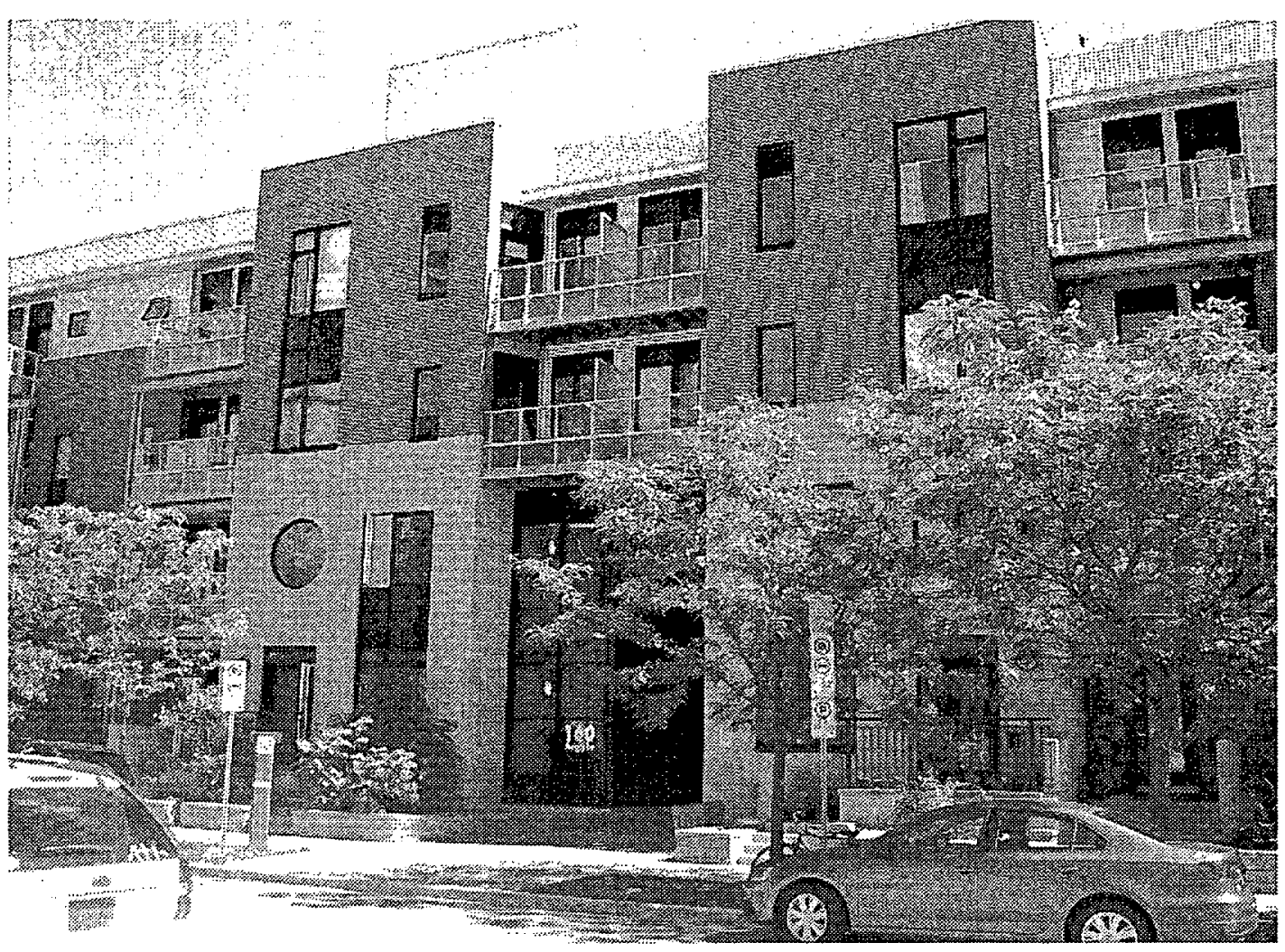

Figure 7.4 CCOC's Beaver Barracks development in downtown Ottawa. Source: Photo taken by author on August 10, 2011.

Ottawa's Multi-Faith Housing Initiative (MHI), a non-profit charitable housing organization, has also found inventive means, in collaboration with government and the private sector, to build affordable rental and ownership housing in Ottawa's urban core. Somerset Gardens, for example, represents an innovative housing partnership between private sector real estate (Teron Inc.), the City of Ottawa, the Province of Ontario and Canadian federal government, and the MHI. Located in downtown Ottawa, the 10-storey development, offers 119 one-bedroom units, combining home ownership at market prices, assisted home ownership, and rental units. MHI owns and operates 10 one-bedroom units in Somerset Gardens and offers these as rental units to low-income households. 
Without question, the type of innovative projects developed by MHI and CCOC to produce new high-density affordable rental and ownership housing geared to low and moderate income families help to mitigate the gentrifying effects of Ottawa's condo boom in neighbourhoods undergoing significant residential intensification in the urban core. However, non-profit affordable housing providers, like $\mathrm{CCOC}$, argue that the recent wave of new high-rise condominium development, facilitated by the City of Ottawa's own 'smart growth' intensification policy, continues to intensify the gentrification of Ottawa's inner urban neighbourhoods. In a special feature in the Ottawa Citizen last July, former CCOC Executive Director, Catherine Boucher, actively involved in affordable housing development in Ottawa's downtown for over 30 years, lamented that when she looks around at the current spate of new high rise development she sees 'mainly one-bedrooms, a community of rich, retired people and yuppie singles' (The Ottawa Citizen, July 2011). The current Executive Director of the CCOC, Ray Sullivan, more recently added that the effect of urban intensification in Ottawa's downtown has been that 'the old affordable inner city began to disappear under the weight of gentrification, and the middle class [and lower income populations] began to lose' (The Ottawa Citizen, April 20, 2012). As a result, Ottawa's inner urban neighbourhoods, today, are less diverse and inclusive of in terms of age, household size, and income than in the past.

Although most of the new condominium developments built under the City's intensification program have not replaced other residential dwellings - most condominium development has been built through the demolition and redevelopment of former commercial, office and institutional properties (such as schools and churches) - and have, therefore, not caused the direct displacement of lower income residents and families, the cost of these new housing developments preclude their purchase by lower income (and even many middle class) 
residents. Moreover, as the image, attractiveness and desirability of neighbourhoods in Ottawa's urban core increase as a result of the City's urban revitalization / intensification program, rising housing prices suggest a form of 'exclusionary' displacement' wherein low income (and middle class) populations are unable to access property because of the gentrification of the neighbourhood. In Ottawa's downtown core, a 2009 CMHC study found, for example, that given the growing desirability of downtown living, '[t]he price level for a home in the downtown area is 28 percent above the average price for the entire Ottawa region, deterring some homeowners from moving into this area' (CMHC 2009, p.3). So where are Ottawa's middle class residents purchasing homes?

Not surprisingly, the failure to ensure that new high density urban development, approved as part of the City of Ottawa's residential intensification and revitalization strategy, incorporates the provision of affordable housing units geared to middle and lower income residents and families appears to have seriously undermined local government efforts to curb regional sprawl a key policy goal of the 2003 Official Plan. According to Canada's 2011 census data, eightythree percent of Ottawa's population growth between 2006 and 2011 occurred outside Ottawa's greenbelt, in suburban and rural areas at the city's edge (Ottawa Citizen, April 20, 2012). This suggests that while intensification may be the most effective way to curb low-density regional sprawl, and its troubling socioecological consequences, affordable housing must be given greater priority in urban debate and policy development. As Executive Director of the CCOC's explains, '[1]ack of affordable housing downtown is partly what's driving urban sprawl. People who want to buy a place have to go to Barrhaven or beyond ... Intensification is the right thing to do, but the city can't ignore the affordable part of the equation. The city has to make sure that as we intensify, a mix of affordability is retained' (The Ottawa Citizen, April 20, 2012). In short, trends 
in Ottawa's housing system, since the adoption of the 2003 Official Plan, suggest that a more socially and environmentally progressive approach to 'sustainable' city building must take seriously the roots of inequity and injustice within the existing political economy of neoliberal capitalism.

\section{“Community benefits": A place for affordability in private sector-led intensification?}

In recent years, residents living in Ottawa's inner urban neighbourhoods, where significant intensification is occurring, have begun to raise the 'affordability question' in the development of Community Design Plans (CDPs) and in the context of community-based struggles over new private sector-led, high density development practices through which residents groups increasingly express the political desire to see 'community benefits' from intensification at the neighbourhood scale.

Until recently, housing affordability had not ranked high on the agendas of local community associations actively contesting new high-rise developments in their neighbourhoods. The vast majority of local opposition to intensification has centred on concerns about the impact of tall buildings on a neighbourhood's existing built landscape and the quality of life of its local residents. From the perspective of community associations, tall buildings mean more traffic, noise, and shadowing effects; they disrupt views and site lines, place new demands on existing infrastructure (roads, public transit, water and sewers), and generally alter the 'character', 'feel', and 'livability' of existing neighbourhoods. However, struggles over building height in neighbourhoods undergoing significant intensification also expose deeper frustrations over what residents view to be a highly uneven and inequitable distribution of benefits that flow from largescale intensification. 
To the question of who gains, and who loses, from new large-scale intensification, community associations argue that private sector real estate developers, routinely granted permission from the City of Ottawa to build taller and denser developments, typically in excess of what is allowed under existing zoning bylaws and community design plans, are positioned to capture surplus profits from new upscale, high rise condominium developments in intensifying neighbourhoods. Likewise, the City of Ottawa enjoys the benefits of a growing inner urban tax base, without the massive public expenditure on new infrastructure and services associated with new suburban 'greenfield' development. What do urban residents receive? In neighbourhoods undergoing significant intensification, one Westboro resident argues, "all we get is condos, with more traffic, and more parking' (Personal interview, April 17, 2009).

Although neighbourhood-based struggles over intensification in Ottawa's urban core are complex, the question of 'community benefits' has become a focal point of recent neighbourhood-based political mobilization. The City of Ottawa adopted Section 37 provisions of the Planning Act as a bylaw in the 2003 Official Plan. To recall, under Section 37 of Ontario's Planning Act, municipalities have the authority to enter into agreements with private sector residential developers to secure community benefits in exchange for an increase in building height or density that exceeds an existing zoning by-law. Community benefits agreements are intended to provide an opportunity for a municipality to capture a share of the added value produced from an increase in building density or height and to pass this 'benefit' along to the neighborhood in which the new development project is located.

Despite having a policy in place under the 2003 Official Plan, the City has not pursued community benefits agreements as part of new high-density urban development approved under the Official Plan's intensification policy. According to City planners interviewed as part of this 
research, the municipality elected to avoid implementing community benefits agreements until they could establish implementation guidelines similar to those used successfully in the City of Toronto. A pressing (and legitimate) concern among municipal officials and planners in the City of Ottawa is the likelihood that, without clear implementation guidelines (and, perhaps, even despite them), real estate developers will simply challenge Section 37 agreements at the Ontario Municipal Board (OMB). In the absence of such agreements, however, real estate developers enjoy the financial rewards of higher density development as of right. Quite crucially, many community associations in Ottawa's urban core view this 'policy failure' as evidence of a 'close alliance' between the municipal government and private sector real estate firms (Personal interview, April 24, 2009).

Since 2003, the City of Ottawa has regularly granted the development applications of real estate development firms seeking an increase in building height or density - a decision that the City justifies as supportive of its urban intensification policy and 'smart growth' mandate without a 'community benefit' agreement in place. Given the slew of new upscale, high density development occurring in inner urban neighbourhoods designated for intensification, the failure to implement community benefit agreements constitutes a significant missed opportunity to build affordability (or other community benefits) into new intensification projects, mitigate the gentrifiying effect of new high rise condominium development, and encourage more socially equitable, inclusive and 'livable' patterns of neighbourhood growth and change. From the perspective of the CCOC, 'Toronto's gotten some excellent stuff out of their community benefits', noting the creation of child-care centres, foot and bike paths, and affordable housing (Centretown News Online, May 2012). 'All of that makes the community better for everybody, 
including the people developers are trying to attract to these buildings. ... It's a win-win situation.' (ibid).

In late 2011 , nearly a decade after the Official Plan was adopted, the City of Ottawa prepared Draft Implementation Guidelines for Section 37 of the Planning Act and Protocol for Negotiating Section 37 Community Benefits (City of Ottawa 2011), a policy development that received immediate and strong support from affordable housing activists and Ottawa's Federation of Citizens' Associations, an umbrella group under which most urban community associations organize collectively. Despite overwhelming public support, the draft guidelines have not yet been formally adopted by the City of Ottawa given last minute objections by Ottawa's real estate development industry. Anticipating their adoption, however, a small number of urban core neighbourhood associations have already identified the potential to build affordability into new high-density development projects and mitigate the gentrifying effects of intensification.

In Old Ottawa East, a largely middle class neighbourhood abutting Ottawa's downtown, recent neighbourhood planning efforts have centred on the anticipated sale and intensification of the institutional lands currently owned by the Oblate Fathers and the Sisters of the Sacred Heart and the potential for new higher density development to contribute to the creation of new affordable housing in the neighbourhood (Figure 7.5). According to John Dance, President of the Old Ottawa East Community Association (OECA), '[d]uring the development of the Old Ottawa 


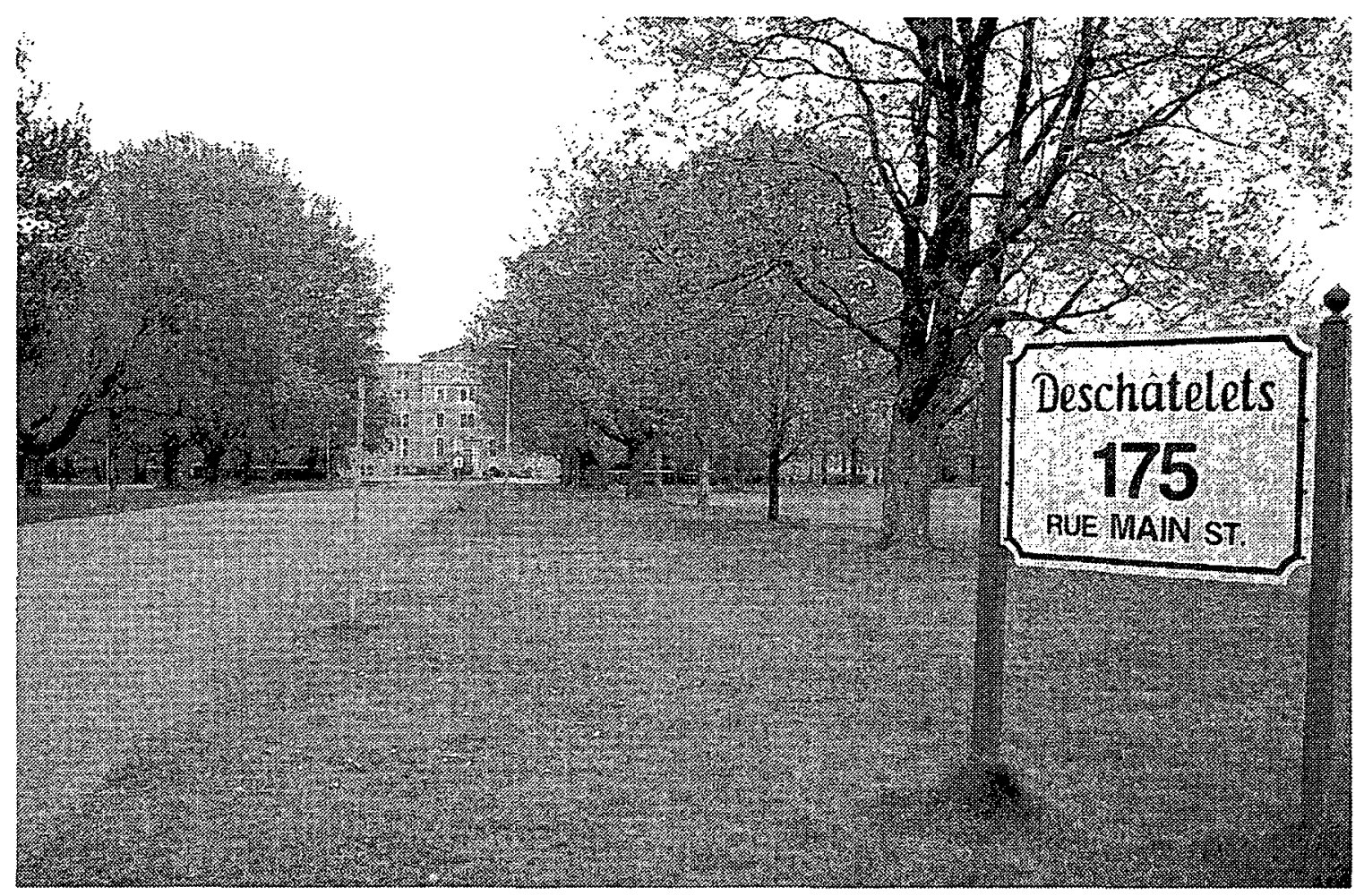

Figure 7.5 Oblate lands located in the neighbourhood of Old Ottawa East, near Ottawa's downtown. Source: Photo taken by the author, May 17, 2010.

East Community Design Plan, there was strong community interest in providing affordable housing so seniors could stay in the community and younger and less affluent people could also find places to live here' (Dance 2011).

In 2010, the Ottawa East Community Association (OECA) began to work with the City of Ottawa, the Oblate Fathers, St. Paul University (located next to the Oblate lands), and other key stakeholders to ensure meaningful community consultation throughout the redevelopment process. A defining feature of the proposed Oblates redevelopment plan is the provision of affordable housing geared towards seniors. Since the City of Ottawa's Section 37 guidelines have not yet been formally adopted by Ottawa City Council, the OECA is presently working with the Ottawa Community Loan Fund (OCLF) to explore possible financial arrangements to build affordability into the Oblate redevelopment plans while also ensuring that the Oblate 
Fathers and Sisters of the Sacred Heart receive a fair market value for the land. The OCLF and OECA are working towards a plan that would see ten to twenty percent of any potential development on the lands be dedicated to affordable senior housing (as defined in the Official Plan). According to OLCF President and OECA member, Michael Oster, '[r]ight now, there are a number of aging households living in Old Ottawa East ... It would be great if there was an option for these residents to both stay in their community and avoid premature entry into the health care system or seniors homes' (Ottawa West EMC News, 2012). Although the sale of the Oblate lands has not yet occurred, the redevelopment plan constitutes a promising, communitydriven effort to build affordable housing into private sector-led intensification projects.

More broadly, the idea of 'community benefits' from new high density urban development constitutes a very timely public challenge to the hegemony of private property rights and the uneven and inequitable distribution of benefits that flow from intensification in the City of Ottawa. Although community benefits agreements can be used to negotiate an array of different community amenities, not strictly affordable housing, it implies that neighbourhoods undergoing significant intensification and change have a stake in, and should share in the benefit from, new private sector property development. This seems quite critical if the City of Ottawa wishes to ensure that intensification contributes to, rather than diminishes, neighbourhood livability for all residents.

\section{Conclusion}

At a time when the vast majority of Canadians now live in cities, it is crucial that debates about the consequences of urban growth and development occupy a central place in urban politics and policymaking. In recent years, discourses of 'smart growth', 'new urbanism', and 'new 
regionalism' have provided a language through which to explore possible socioecological alternatives to historical patterns of low-density, automobile dependent suburbanization as part of an effort to build more environmentally 'sustainable', socially 'livable' and 'inclusive' cities. However, in sharp contrast to the vision of 'smart growth' espoused in the City of Ottawa's Official Plan, urban intensification, over the last several years, has largely taken the form of upscale condominium (and townhouse) development concentrated in Ottawa's urban core, suggesting a close alignment between the City's policy of urban intensification and marketdriven, private sector inner city residential development in Ottawa. The explosion of new-build medium and high-rise condominium development has created thousands of new residential units in Ottawa's downtown and in surrounding mature urban neighbourhoods - evidence of successful urban intensification and revitalization from the perspective of city officials and planners. However, condominium development has produced mostly small but expensive urban housing geared to the consumer demands of the city's relatively affluent retiring baby boomers and young professionals attracted to the convenience of downtown living at the expense of lower income households, most of whom are renters, or the ten thousand households that remain on Ottawa's social housing waiting list. Without commensurate capital investment in new rental housing, particularly that geared to low-income families, the City's policy of urban intensification appears to constitute little more than 'policy-led' gentrification as a lack of (truly) affordable (rental) housing and rising housing prices limit opportunities for low income (and increasingly, middle class) households to live in Ottawa's city centre.

The argument and evidence presented here contributes to the emerging body of recent scholarship, in and beyond the field of urban political ecology, that highlights the troubling role of public sector 'urban sustainability' policies in facilitating private sector-led urban 
development and gentrification practices, producing new patterns of social exclusion in the urban built environment (Lees 2003; Davidson and Lees 2005; Larsen 2005; Bunce 2009; Lehrer and Weiditz: Quastel 2009). This is not to argue, however, that City officials and planners intentionally sought to encourage gentrification processes, erode housing affordability, and provoke the displacement of low-income households from Ottawa's city centre. To understand how urban intensification unfolded as it did requires that the concept of 'policy-led' gentrification be situated in the context of broader political economic transformations and their impact on urban governance regimes. Provincial-municipal restructuring in Ontario since the mid-1990s, which included the downloading of provincial responsibilities for social housing, public transit, water and sewer and other urban infrastructure and services to fiscally constrained municipalities, has forced the hand of many local governments to embrace more entrepreneurial and competitive styles of urban governance that prioritize economic development over more socially and environmentally progressive policy goals. In terms of planning, this has meant that municipalities like the City of Ottawa have embraced a 'growth first' approach to urban development in an effort to stimulate the physical and economic revitalization of their city centres and strengthen urban economic competitiveness while, simultaneously reducing municipal spending on new growth related infrastructure and services - this is why 'smart growth' has become such an appealing policy discourse in municipalities across Canada, as elsewhere.

The failure of Ottawa's intensification policy to build affordability into new privatesector led, high density residential development certainly constitutes a missed opportunity to address, however modestly, Ottawa's crisis of housing (in)affordability. However, this responsibility (or failure) does not fall on the shoulders of the municipality alone. Rather, a long- 
term sustainable approach to housing affordability and socially inclusive urban intensification and city centre revitalization requires a comprehensive and long-term strategy and funding commitment by federal and provincial levels of government and the deliberate coordination of housing and planning policy at the municipal scale to ensure that cities can become more sustainable, livable and inclusive for all.

As a promising first step, Toronto MPP Cheri DiNovo is expected to reintroduce a private member's (previously Bill 198) in the Ontario legislature in the fall of 2012, to amend Ontario's Planning Act with respect to inclusionary housing. The bill is expected to propose changes to sections 34 and 37 of the Planning Act to allow municipal councils to pass zoning bylaws requiring inclusionary housing in the municipality and regulating the required percentage of affordable housing units in new private sector residential developments in the municipality. The proposed bill is also expected to contain an amendment to Section 51 of the Act to allow municipal planning authorities to impose as a condition to the approval of a plan of subdivision a requirement that a specified percentage of housing units in all new housing developments in the subdivision be affordable to low and moderate-income households. Giving municipalities the legislative authority, under the Ontario Planning Act, to 'require' the inclusion of affordable housing in new private sector development will strengthen the position of municipalities vis-àvis developers, reducing the potential for protracted and costly appeals to the OMB. But more than this, the adoption of an inclusionary housing policy in Ontario will go a long way towards ensuring that municipal 'smart growth' intensification policies, and the private sector urban development practices they enable, advance a more socially equitable and environmentally sustainable urban transformation in Ontario municipalities. 


\section{Chapter 8}

\section{Conclusion}

The City of Ottawa's 2003 Official Plan proposed big change. It advanced a grand vision and ambitious plan for the city's future growth premised on reducing regional sprawl and promoting a more 'sustainable', 'livable' city region for all residents. The Plan promised to conserve Ottawa's agricultural land, its forests, wetlands and other sensitive natural environments across the region from unnecessary, or at least premature, suburban expansion. It promised to make future growth as efficient and cost effective as possible by directing new development to the city's existing built landscape where municipal infrastructure and services were already available. It promised compact, mixed use urban development that was transit oriented, pedestrian friendly and 'complete', enabling residents to live nearer to places of work, entertainment and recreation and to access their daily needs locally, without the need of a car. It also promised that new high density residential development, approved under the City's intensification strategy, would provide more diverse and affordable housing types and tenures (including rental housing) and, in so doing, create more socially mixed and inclusive neighbourhoods inside the city's existing built landscape and curb regional sprawl. In short, it promised to begin to work towards building a more environmentally sustainable and socially just urban future.

Certainly, change of this kind does not happen swiftly or smoothly, in the absence of obstacles, debate or resistance. Ottawa 20/20's smart growth policy framework proposed a socioecological transformation of the city region that, in scale and vision, is not unlike that of Wilfred Laurier and William Lyon Mackenzie King's vision for Canada's capital city at the turn of the twentieth century or, more recently, Jacques Gréber's infamous post-war plan to transform 
Ottawa into a thriving, modern (suburban) metropolis. And, it would be both unfair and misleading to deny that the City of Ottawa has made meaningful progress since the adoption of its Official Plan, at least in terms of securing a place for environmental and social issues in public and political debate about the city's future growth and development. That said, this research suggests that the City's new sustainability agenda and its smart growth-inspired urban intensification strategy, as they have been conceived and implemented to date, fall drastically short of delivering a more sustainable and socially equitable city region. In fact, early evidence suggests quite the opposite may be true.

Using the City of Ottawa as a case study, the overarching goal of this piece of research has been to critically examine how discourses of urban environmental 'sustainability' and 'livability' are being actively incorporated into recent 'smart growth' inspired urban policy, planning and development practices in an era of intense political economic restructuring and governance change at different scales in Canada. This chapter provides a brief review of key arguments and insights presented in this thesis, including its empirical and theoretical contributions to the field of urban political ecology, and identifies potential avenues for future empirical research and theoretical examination. The chapter concludes with a brief discussion of the potential contribution of the thesis' research findings to on-going public debate and policy development processes in the City of Ottawa and, perhaps, other municipalities experimenting with smart growth policy and planning reforms across Canada. 


\section{Key insights and contributions to UPE scholarship}

Over the last decade, the field of UPE has produced theoretically and empirically rich real-world case studies and analyses that seek to reinsert questions of nature, environment and sustainability into urban debate and academic scholarship. While the terrain of recent UPE research has become increasingly broad in scope, covering themes as diverse as the political ecology of urban water regimes (Swyngedouw 2004, 2005; Kaika, 2005, 2006; Young and Keil 2005; Loftus 2006; Smith and Ruiters 2006), urban forests and parks (Heynen 2003), suburban lawnscapes (Feagan and Ripmeester 1999; Robbins and Sharp, 2003a, 2003b, 2006), urban hunger (Heynen et al. 2006) and 'obe-city' (Marvin and Medd 2006), urban air pollution (Veron 2006), urban warfare (Graham 2004, 2006), and (un)natural disasters in urban landscapes (Martin 2009), comparatively less attention has been directed to the political ecological dynamics and consequences of contemporary urban and regional planning and everyday development practices in cities. This piece of research, I hope, makes a modest contribution to recent scholarship that has begun to address this gap in both the UPE and urban studies literatures (see, for example, Keil and Graham 1998; Bunce 2004, 2009; While et al. 2004).

One of the broad goals of this research has been to contribute to the growing body of UPE scholarship that elaborates a view of urbanization as a complex and dynamic process of socialecological change. In recent years, as the political-economic, social and ecological consequences of traditional post-war patterns of low density (sub)urbanization became more apparent in Ontario municipalities, as elsewhere in Canada, regional 'sprawl' emerged as an object of intense public debate and political calculation, giving rise to an array of urban environmental policy and planning reform experiments at municipal and provincial levels. From the perspective of UPE, this research took as its starting point that 'smart growth', as a new 
urban environmental policy and planning regime in Ontario, represents an effort to articulate and set in motion a process of socioecological transformation in Ontario cities - one premised on directing and concentrating future growth in a city's existing built landscape and encouraging more compact, mixed use urban development patterns in order curb regional 'sprawl' and create more environmentally 'sustainable' and socially 'livable' city regions.

Drawing on insights from recent UPE scholarship, a goal of this research was to develop an understanding of recent smart growth urban policy and planning reform experiments, and the new urban environments they have given rise to, as historically and geographically situated, produced through a complex array of dynamic and power-laden relations and processes that are, at once, political and economic, social and ecological, material and discursive. In particular, by situating the politics of sprawl and the emergence of Ottawa's new 'smart growth' urban planning framework and intensification policies in the context of recent political economic restructuring and governance change at different scales, this thesis sought to make explicit the ways in which discourses of 'environment' and 'sustainability' have become internal to neoliberal forms of capitalist urbanization and uneven development in recent years.

More specifically, a key argument developed throughout this thesis is that the shift towards more 'ecologically-sensitive' and 'sustainable' approaches to urban planning and development are not simply embedded in, but constitutive of, a new wave of neoliberal urbanization in the City of Ottawa and, perhaps, more broadly, throughout Ontario and other parts of urban Canada. Although 'smart growth' is often championed in Canadian urban policy and planning communities as a sustainable alternative to low density regional sprawl, evidence presented in Chapters 4 through 6 suggests that the integration of sustainability objectives into 'smart growth' municipal policy and planning has been highly conditioned by recent provincial- 
municipal restructuring in Ontario and urban governance reform in the City of Ottawa. More than a decade of dramatic cuts in federal and provincial public spending, followed by the progressive downloading of key responsibilities for public infrastructure and services from senior levels of government to municipalities created new policy and planning dilemmas for cities throughout Ontario and across much of urban Canada. With grossly inadequate fiscal resources and limited legislative authority to pursue new streams of municipal revenue to meet these burgeoning responsibilities, cities have shifted towards a more entrepreneurial style of municipal governance, experimenting with a range of urban policy and planning reform strategies geared towards, on one hand, 'optimizing' efficiency and 'rationalizing' public spending within local government and, on the other, mobilizing urban space to enhance Ottawa's economic competitiveness and sustain long-term growth.

'Smart growth' planning reforms introduced by the Ontario Harris-Eves government in 2000, and quickly 'taken up' by municipalities across the province shortly thereafter, I argue, appeared to represent, at least in part, a provincial and municipal policy experiment to manage the inherent contradictions, crises and governance dilemmas created by recent waves of neoliberalization in Ontario. By directing new development to existing built up areas of the city, where infrastructure and services are already available, and requiring that future growth in Ottawa's suburbs 'pay for itself' through a combination of development charges and user fees, the City's 'smart growth' intensification and growth management policies appeared to fit neatly within broader processes of provincial-municipal restructuring and urban governance reform prioritizing efficient, cost effective and 'fiscally sustainable' growth in the city region.

At this same time, provincial planning reform and municipal experimentation with smart growth urban intensification and growth management strategies has also played a key part in the 
rolling out of a new, and highly ambitious, urban entrepreneurial agenda premised upon stimulating the physical and economic revitalization of Ottawa's urban core. Clearly swayed by Richard Florida's (2002) 'creative city' doctrine, the City of Ottawa's Official Plan, and supporting intensification policies adopted since 2003, take the position that Ottawa's economic competitiveness and long-term prosperity hinge on the City's ability to attract and retain the kinds of capital investment and professionally skilled 'creative' labour driving knowledge economy growth in the region. In particular, creating economically vibrant, socially livable, and environmentally rehabilitated downtown spaces that are people-centred and business-friendly became high priority and a focal point of municipal policy and planning.

Although initially conceptualized and put forward to the public as a comprehensive, city regional approach to sustainable and environmentally sensitive land-use planning and development, evidence presented in this thesis suggests that since the Official Plan's adoption in 2003, 'smart growth' has become, first and foremost, a spatially-targeted revitalization through intensification effort focused on facilitating new market-driven high density residential and commercial development in Ottawa's downtown and surrounding mature urban neighbourhoods. Coupled with strategic public sector investment in new upscale urban infrastructure, amenities, and urban and environmental design features, the City of Ottawa's intensification program appears ultimately geared toward remaking Ottawa's inner urban environments in order to promote image of the city as an attractive place to live and invest.

In this respect, more broadly, I hope the case study presented here helps to elaborate and build on existing lines of inquiry into the inherently political nature of 'sustainability' and the policies, programs and development practices - like smart growth - with which it has become associated (Marcuse 1998, Raco 2005; Gunder 2006; Bunce 2009). The language of 'triple 
bottom line' (Brassoulis 1999) policy development implies that economic competitiveness, environmental stewardship, and social equity are mutually reinforcing policy goals. In this respect, 'sustainability' is suggestive of the kind of 'win-win(-win)' discourse that lies at the very heart of the contemporary politics of ecological modernization (Hajer 1995; Harvey 1996). Without denying progress made in securing a place for issues of environment and sustainability in debates about the Ottawa's future growth and development, this thesis draws critical attention to the partial and selective incorporation of environmental goals in the City's smart growth intensification strategy, providing insight into the particular governance and policy dilemmas that Ontario municipalities currently face in balancing economic, social and environmental demands in an era of political-economic restructuring. Ultimately, how 'sustainability' is defined and taken up in policy entails political choices that are variously enabled and constrained by broader political-economic transformations at different scales. In this respect, I hope this research makes a small contribution towards unsettling the hegemonic status of 'urban sustainability' by making visible its inherently partial and political nature and exposing its complicity in current processes of uneven geographical development in, and beyond, the urban.

The implications, for social equity and justice, of the City of Ottawa's smart growth urban policy and planning experiment and the socioecological transformation of the urban landscape it implies, have been a central focus of this thesis. Social equity is often taken to be intrinsic to ideas of 'sustainability' and 'sustainable development'. Prevailing discourses of 'sustainability' take as given that sustainability means the same things to all people, that all humanity has a common stake in 'sustainability' and that policies advancing 'sustainability' as an objective and end goal serve an undifferentiated public - that we all benefit equally from 'sustainability' (Marcuse 1998; Meadowcroft 1999). However, given the particular governance 
dilemmas, compromises and opportunities associated with the advance of urban neoliberalization, discourses of 'sustainability', and the urban policies and development practices they inform, are not necessarily socially equitable or just.

I believe this thesis makes a contribution to current UPE and urban studies literatures that draw critical attention to the ways in which particular processes of urban socioecological change often entail the production of spatially differentiated, highly uneven and deeply unjust urban landscapes. In particular, it questions who gains and who loses, who benefits and who suffers, from 'smart growth' intensification policies and the development practices they authorize in the City's built environment. Given the ascendance of an increasingly entrepreneurial style of urban governance in the City of Ottawa, and the apparent privileging of urban competitiveness and economic growth as policy goals, early evidence suggests that the City's 'smart growth'-inspired urban environmental policy regime and intensification practices have done little to curb regional sprawl (and its socio-ecological consequences) and encourage the creation of more environmentally sustainable and socially inclusive places to live and work across the city region - explicit goals of the City's 2003 Official Plan. Although urban development and regional growth are complex, dynamic and inherently political processes, the matter of housing affordability and choice, I have argued, lies at the very heart of the problem.

Given the City's preoccupation with stimulating new upscale residential development in Ottawa's urban core as part of its revitalization through intensification mandate, policies approved since the 2003 Official Plan have been geared toward facilitating new market-driven high density urban development practices. Reducing regulatory barriers to intensification, making zoning bylaws more 'flexible' and 'responsive', and creating financial incentives to encourage the remediation and redevelopment of urban brownfield sites became key policy 
priorities. The issue of housing affordability, however, has received far less policy attention. Although Ottawa's Official Plan and City Housing Policy argue persuasively that new high density development holds the potential to create more diverse housing types and tenures, improve housing affordability and choice in Ottawa's urban core, and thus reduce regional sprawl, findings from this research project suggest that the City's intensification policies, in practice, have been closely aligned with market-driven urban development practices in Ottawa's city centre. In this respect, I argue that intensification, as it has been defined and implemented in the City of Ottawa, appears to constitute a form 'third wave' or 'policy-led' gentrification (Hackworth and Smith 2001) to the extent that it has unfolded through a strategic partnership between private sector capital and local government policy, with relatively little attention directed to the potential social and ecological implications of this urban transformation.

Consistent with Hackworth and Smith's (2001) theorizing of policy-led gentrification, early evidence, presented in Chapter 7, suggests that municipal policy support for new private sector condominium development in Ottawa has sparked a new wave of capital reinvestment, transforming the city's socioecological landscape in the last decade. Without argument, intensification has gone a long way towards promoting the physical and economic revitalization of Ottawa's urban core, reversing patterns of depopulation and decline that defined the area in previous decades. Although modest when compared to on-going explosive population growth in the region's suburban communities, recently released 2011 census data shows that, between 2006 and 2011, five percent of Ottawa's population growth occurred in its city centre (Ottawa Citizen 2012). Today, a walk through Ottawa's Centretown and Byward Market areas or along traditional mainstreets in neighbourhoods like Hintonburg and Westboro, Sandy Hill, Vanier, and the Glebe, reveals a flurry of new upscale, medium and high-rise condominium development 
as well as public reinvestment in urban infrastructure (for example, upgraded water and sewer infrastructure, community facilities and pedestrian walkways) and environmental amenities (such as revitalized parks, open spaces, urban trees, and attention to landscaping and other aspects of environmental design) that have attracted new residents, retail and other commercial activity back to the city centre. In strictly economic terms, a physically revitalized and economically vibrant downtown may be good for Ottawa, but the benefits of this urban transformation have not been equally shared by all residents. In short, some have benefited from intensification, others have not.

Who wins from intensification? The City's revitalization through intensification strategy clearly benefits Ottawa's municipal government by attracting new capital investment, labour, and tourists to the city region. New high-rise residential and commercial development in Ottawa's downtown expands the city's tax base with less public expenditure, by the municipality (and other levels of government), on new infrastructure and services, relative to new low-density suburban development. The City's intensification strategy and supporting policies geared toward reducing regulatory and financial barriers to new high-density residential development in the city's urban core, has also benefited Ottawa's downtown real-estate developers who are reaping the profits that accompany new upscale condominium development in a hot real estate market. Likewise, consumers of new upscale condominium units, namely Ottawa's relatively affluent, young urban professionals and retired empty nesters eager (and financially able) to enjoy the benefits of 'downtown living', have gained from this new urban enviornmental policy and development strategy.

But who loses from intensification? Measured against the Official Plan's targets for housing affordability in new-built development, findings from this research suggest that 
intensification has done little to advance the creation of new affordable housing units in Ottawa's urban core and, as such, constitutes a significant missed opportunity, on the part of the municipality, at a time when senior levels of government have withdrawn from and devolved responsibility for affordable housing production to localities. In fact, it seems likely, even inevitable, that new upscale condominium development will serve to deepen prevailing patterns of housing insecurity and social-spatial exclusion in Ottawa's downtown neighbourhoods.

As housing prices continue to skyrocket in 'intensifying' urban neighbourhoods, there is a danger that the City's intensification and revitalization practices may produce new forms of 'exclusionary' displacement' (Davidson and Lees 2005) as low income (and even middle class) populations are unable to afford housing, either through purchase or rental agreements, in Ottawa's urban core - a hallmark of the contemporary gentrification. In this respect, Chapter 7 advances the argument that without commensurate (public and/or private) capital investment in new affordable housing development, particularly that geared to low-income families, the City of Ottawa's 'smart growth' urban intensification / revitalization program is likely to intensify, rather than ameliorate, existing patterns of inequality and vulnerability in Ottawa's housing system and diminish the 'livability' of Ottawa's downtown and neighboring urban districts undergoing intensification for people living on low income. In the broadest sense, such findings expose the troubling ways in which discourses of 'sustainability' and the urban policies and development practices they inform, have the potential to undermine, rather than advance, social equity, inclusion and justice.

And what about the socioecological 'crisis' of sprawl? Early evidence suggests that the City of Ottawa's support for private sector-led high density development, coupled with the lack of new affordable housing produced through intensification in Ottawa's urban core, have 
thwarted the City's current efforts to curb low density suburban growth in the Ottawa region. Escalating housing prices in Ottawa's downtown relative to new built residential development in Kanata, Stittsville, Riverside South, Barrhaven, and Orléans, continues to favour Ottawa's suburban housing market. As a consequence, low-density suburban development continues, relatively unabated, in Ottawa's periphery intensifying pressures on the city's agricultural land and fragile, life-sustaining ecologies like Ottawa's Leitrim wetlands and South March Highlands. In short, despite the rhetoric of 'sustainability' that saturates Ottawa's Official Plan and supporting intensification policies, in an era of neoliberal political economic restructuring and governance change, 'smart growth' has done little to advance municipal policy, planning and development practices towards the creation of a more environmentally sustainable and socially equitable city region.

\section{Future research directions}

Although the City's smart growth intensification strategy has been in place for nearly ten years now, urban planning and development are long, slow processes and change to Ottawa's urban socioecological landscape will be incremental. Many of Ottawa's downtown and surrounding inner neighbourhoods have become 'hotspots' for intensification in recent years, transforming mainstreets into high density, mixed use hubs of new residential, retail and commercial activity. Outside the downtown, intensification has been comparatively slow and largely sporadic. However, as opportunities for property redevelopment and urban infill in Ottawa's downtown become sparse in the years to come, intensification along Ottawa's public transit corridors, arterial roads, and in other areas designated for future high density, mixed use urban development outside the urban core is likely to gain traction. Future prospects for 'retrofitting' 
Ottawa's suburbs to accommodate higher density, mixed use and transit-oriented urban development patterns are, at present, uncertain. Precisely how smart growth intensification processes will transform Ottawa's variegated urban and regional landscape over time, and with what effects, both in terms of environment and social justice, remain open questions deserving of further exploration.

In the City of Ottawa, smart growth intensification, as an urban planning regime and process of socioecological transformation, is still in a formative stage. As such, the research that informs this thesis constitutes only a 'first cut', a glimpse into the complex, dynamic and multiscalar set of political-economic, social and ecological relations and processes shaping urban governance and policy change, as well as everyday planning and development practices in the City of Ottawa. Over the coming decade, there is considerable potential to explore the ways in which the City of Ottawa's smart growth planning framework, intensification policies, and development practices in and outside of Ottawa's urban core continue to evolve in relation to ongoing political economic restructuring and governance reform and transform Ottawa's socioecological landscape at different scales - at neighborhood, urban, and regional levels.

In particular, a comprehensive, longer term study of the impacts of market-driven, high density urban development practices on housing affordability and demographic change in 'intensified' neighbourhoods would help to more clearly establish the relationship between the City of Ottawa's urban intensification strategy and processes of gentrification. Moreover, as gentrification in downtown neighbourhoods produces an escalation in land and housing prices, and intensification practices expand outward from Ottawa's downtown along the city's rapid transit corridors and to mixed use 'towncentres' in Ottawa's suburbs, the extent and ways which urban and suburban districts beyond the urban core 'become caught up in the momentum of 
gentrification' (Smith 2002, p.442) will prove fertile ground for empirical research and theoretical development.

More broadly, longer term analysis of housing market trends at an urban/regional scale vis-à-vis the City's smart growth planning framework, intensification policies and development would go a long way towards reinforcing the crucial point that the socioecological crisis of sprawl is ultimately a crisis of (un)affordability. This insight speaks to Haughton's (1999, p.234) broader argument that ideas of 'sustainability', and the policies and development practices with which they have become associated, acknowledge (in a meaningful way) 'the interdependency of social justice, economic well-being and environmental stewardship'.

Finally, given that 'smart growth' has been widely adopted in municipalities across Canada, a comparative study of 'smart growth' inspired policy experiments, planning reform measures and development trajectories in different urban and provincial contexts would offer considerable insight into the progressive potential and limitations of 'smart growth' in a period of intense governance and policy change. To what extent have different municipalities in Ontario (for example, Toronto), or in other provincial contexts, successfully incorporated affordable housing in new high-density urban development? What municipal policy or provincial legislation accounts for the success? What other factors enable or constrain the capacity (and willingness) of municipalities to ensure that new private sector housing development includes affordability?

\section{Contributions to municipal policy development}

Just weeks ago, in April 2012, the City of Ottawa held a Planning Summit during which municipal officials and planners reasserted and reinforced the City's political commitment to 'smart growth', downtown intensification and revitalization, and the creation of higher density, 
mixed use and transit-oriented neighbourhoods, in city and suburb alike, across the Ottawa region. At the centre of debate, during the Summit, was concern over mounting neighborhoodbased opposition to new intensification projects, particularly in the Ottawa's urban core, and the slow pace of development approvals for new high-density development in the City of Ottawa. Questions surrounding the highly problematic social and ecological implications of the City's smart growth strategy and intensification policies, as they have been conceived and implemented to date, were not atop the agenda. If the City of Ottawa chooses to continue to champion 'smart growth' as an urban environmental policy and planning regime intended to curb low-density regional sprawl and build more sustainable, livable and inclusive places to live and work, at a neighbourhood, urban and regional scale, the findings from this research lead to three mutuallyreinforcing policy recommendations.

First, the findings of this research suggest that issues of housing affordability and choice must figure more prominently in public debate and municipal policymaking tied to 'smart growth' and 'sustainable' urban planning and development. In the last decade, since the adoption of the 2003 Official Plan, the lack of critical public and political engagement on issues of housing affordability vis-à-vis the implementation of 'smart growth', has given rise to intensification policies and development practices that privilege upscale, high density condominium development over the production of new affordable housing units in neighbourhoods targeted for intensification. Early evidence suggests that in the absence of strong and enforceable policies requiring that new affordable units be created as part of City-approved intensification projects, new market-driven condominium development - approved in the name of 'smart growth', 'sustainability' and 'livability' - is likely to intensify patterns of inequality and exclusion if low income (and even middle class) residents and families are either directly or 
indirectly displaced from intensified neighborhoods in the wake of gentrification and forced, by necessity, to seek housing outside Ottawa's urban core and in its more distant suburbs. In keeping with the spirit of the Official Plan, this research suggests that intensification policies geared toward building affordability into new high-density private sector development - for example, through density bonusing agreements, under Section 37 of the Ontario Planning Act can make a meaningful contribution towards curbing sprawl and creating more socially equitable and inclusive urban neighbourhoods and a more sustainable city region.

Second, as the city's population continues to grow, and opportunities for intensification in Ottawa's urban core become scarcer, the City of Ottawa will be forced to implement policy to stimulate higher density, mixed use and transit-oriented development in the region's rapidly growing suburbs. To date, intensification practices have been largely concentrated in Ottawa's downtown and surrounding neighbourhoods inside the greenbelt while growth in suburban communities predominantly takes the form of lower-density, automobile-dependent development. Building on the first point above, however, it is crucial that municipal policies geared toward promoting suburban intensification make housing affordability a priority in order to ensure that new high density suburban development contributes to a more balanced, equitable and ultimately sustainable housing system.

Finally, policy change at senior levels of government appears imperative. This coming fall 2012, the reintroduction of MPP Cheri DiNovo's private member's bill in the Ontario legislature to amend Ontario's Planning Act with respect to inclusionary housing seems promising. Municipalities urgently need greater authority, under the Ontario Planning Act, to 'require' the inclusion of affordable housing as part of all new private sector urban development. The City of Ottawa has been reluctant to utilize Section 37 'community benefits' agreements 
precisely because they are 'voluntary', opening the door for real estate developers to initiate protracted and costly OMB appeals (where municipalities are typically at a disadvantage). Giving municipalities the legislative authority, under the Ontario Planning Act, to 'require' the inclusion of affordable housing in new private sector development will limit the ability of developers to challenge municipal inclusionary housing policies at the OMB. But more than this, the adoption of an inclusionary housing policy in Ontario will go a long way towards ensuring that municipal 'smart growth' intensification programs and private sector urban development practices contribute to, rather than diminish, social equality, 'livability', and, ultimately, 'sustainability' at the neighbourhood and urban scale in Ontario.

More broadly, in the wake of more than two decades of political economic restructuring and reform, it seems imperative that municipalities like the City of Ottawa continue to press senior levels of government to commit to a comprehensive long-term funding strategy geared toward reducing poverty, housing insecurity and homelessness in Canadian cities. Inequality, in all its forms, undermines the progressive potential of 'smart growth' and other urban policy experiments that seek to build more 'sustainable' cities. 


\section{BIBLIOGRAPHY}

Alliance to End Homelessness (ATEH). 2010. Report Card on Ending Homelessness in Ottawa: January to December 2010.

Arigoni, D. 2001. Affordable Housing and Smart Growth: Making the Connection, Washington DC: National Neighborhood Coalition.

Big City Mayors' Caucus. 2006. Our Cities Our Future: Addressing the fiscal imbalance in Canada's cities today. June 2006.

Blaikie, P. 1985. The Political Economy of Soil Erosion. London: Methuen.

Blaikie, P. and Brookfield, H. 1987. Land Degradation and Society. London: Methuen.

Blickstead R. and Shapcott, M. 2010. Strengthen Ontario's Provincial Policy Statement as one tool to meet the province's housing needs. Submission by Wellesley Institute to PPS fiveyear review.

Boudreau, J., Keil, R. and Young, D. 2009. Changing Toronto: Governing urban neoliberalism. Toronto: University of Toronto Press.

Bourne, L. 2001. The Urban Sprawl Debate: Myths, Realities and Hidden Agendas, Plan Canada, 41(4), 26-28.

Bradford, N. 2002. Why Cities Matter: Policy Research Perspectives for Canada. Ottawa: Canadian Policy Research Networks Inc.

Braissoulis, H. 1999. Who plans whose sustainability? Alternative roles for planners, Journal of Envrionmental Planning and Management, 42(6), 889-902.

Braun, B. 2002. The Intemperate Rainforest: Nature, Culture and Power on Canada's West Coast. Minnesota: University of Minnesota Press.

Brenner, N. and Theodore, N. 2002. Cities and the geographies of "actually existing neoliberalism.' In N. Brenner and N. Theodore (Eds.), Spaces of neoliberalism: Urban restructuring in North America and Western Europe (pp. 2-32). Oxford: Blackwell.

Bromley, D.F., Tallon, A.R., and Thomas, C.J. 2005. City Centre Regeneration through Residential Development: Contributing to Sustainability, Urban Studies, 42(13), 2407-2429.

Bunce, S. 2004. The Emergence of 'Smart Growth' Intensification in Toronto: environment and economy in the new Official Plan. Local Environment, 9 (2), 177-191. 
Bunce, S. 2009. Developing sustainability: sustainability policy and gentrification on Toronto's Waterfront, Local Environment, 14, 651-667.

Burton, E. 2003. Housing for an Urban Renaissance: Implications for Social Equity, Housing Studies, 18(4), 537-562.

Canada Mortgage and Housing Corporation (CMHC). 2002a. Housing Market Outlook: City of Ottawa, Spring 2002.

_ 2002b. Housing Market Outlook: City of Ottawa, Fall 2002.

- 2003a. Housing Market Outlook: City of Ottawa, Spring 2003.

—_ 2003b. Housing Market Outlook: City of Ottawa, Fall 2003.

__ 2004a. Housing Market Outlook: City of Ottawa, Spring 2004.

_ 2004b. Housing Market Outlook: City of Ottawa, Fall 2004.

2005. Smart Growth in Canada: A Report Card. CMHC Research Highlight. Socioeconomic Series No. 05-036.

2006. Housing Market Outlook: City of Ottawa, Fall 2006.

— 2007. Housing Market Outlook: City of Ottawa, Fall 2007.

2008. Housing Market Outlook: City of Ottawa, Fall 2008.

— 2009. Housing Market Outlook: City of Ottawa, Fall 2009.

— 2010a. Housing Market Outlook: City of Ottawa, Spring 2010.

- 2010b. Housing Market Outlook: City of Ottawa, Fall 2010.

_2011a. Housing Market Outlook: City of Ottawa, Spring 2011.

_ 2011b. Housing Market Outlook: City of Ottawa, Fall 2011.

Canadian Environmental Law Association (CELA). 1996. Submissions of the Canadian Environmental Law Association to the Standing Committee on Resources Development Reviewing Bill 20, the "Land Use Planning and Protection Act", February 1996.

2001. Provincial Policy Statement Five-Year Review: Response by the Canadian Environmental Law Association to the Request by the Ministry of Municipal Affairs and Housing for Public Comments. Environmental Bill of Rights Registry Number PF01E0002. October 12, 2001. 
- 2004. Provincial Policy Statement: Draft Policies, 2004. Submissions of the Canadian Environmental Law Association to the Ministry of Municipal Affairs and Housing, Environmental Bill of Rights Registry Number PF04E0003.

- 2006. Comments on Bill 51 Planning and Conservation Statute Law Amendment Act, 2005. EBR Registry Number AF05E0001. Letter to Ken Peterson, Manager, Provincial Planning and Environmental Services Branch, February 24, 2006.

Castree, N. 1995. The Nature of Produced Nature: Materiality and Knowledge Construction in Marxism, Antipode, 27(1), 12-48.

2001. Socializing Nature: Theory, Practice, and Politics. In N. Castree and B. Braun (Eds.), Social Nature: Theory, Practice, and Politics. Oxford: Blackwell Publishers.

Castree, N. and Braun, B. 1998. The Construction of Nature and the Nature of Construction: Analytical and political tools for building survivable futures. In B. Braun and N. Castree (Eds.), Remaking Reality: nature at the millennium (pp. 3-42). London: Routledge.

City of Ottawa 2003a. City of Ottawa Official Plan, as adopted by City Council, May 2003. Publication No. 1-28. City of Ottawa, Planning and Growth Management Department.

2003b. Ottawa 20/20 Human Services Plan. City of Ottawa, Planning and Growth Management Department.

- 2003c. Ottawa 20/20 Economic Strategy. City of Ottawa, Planning and Growth Management Department.

2003d. Ottawa 20/20 Environmental Strategy. City of Ottawa, Planning and Growth Management Department.

- 2004a. Report to Council: Summary of the 2004 Draft Budget Estimates. February 11, 2004. Ref No: ACS2004-CMR-OCM-0005.

2004b. Long-Range Financial Plan: Overview. Retrieved December 8, 2010. http://www.ottawa.ca/city hall/financial/lrfp/lrfp_final_draft I en.html.

— 2004c. Budget 2004: Highlights. Retrieved December 8, 2010. http://ottawa.ca/city hall/budget/previous budgets/budget 2004/council highlights en.html.

2004d. Where Will We Live?: Housing potential in Ottawa 2002. Publication No. 13-23. City of Ottawa, Planning and Growth Management Department.

— 2004e. Downtown Ottawa Urban Design Strategy 20/20: Reshaping the future of Ottawa's Downtown. City of Ottawa, Planning and Growth Management Department. 
- 2006a. Urban Design Guidelines for Development along Traditional Mainstreets.

Publication No. 21-03. City of Ottawa, Planning and Growth Management Department.

2006b. Urban Design Guidelines for Development along Arterial Mainstreets. Publication No. 21-04. City of Ottawa, Planning and Growth Management Department.

- 2006c. Annual Development Report 2005. Publication No. 12-35. City of Ottawa, Planning and Growth Management Department.

2007a. City Strategic Plan: Term of Council 2007-2010, Pre-Budget Version. Ottawa: City of Ottawa.

— 2007b. Ottawa Budget 2008: Maintaining Our Infrastructure (leaflet). Ottawa: City of Ottawa.

2007c. City of Ottawa: Fiscal Framework. Ottawa: City of Ottawa.

- 2007d. City Housing Strategy, 2007-2012. City of Ottawa, Planning and Growth Management Department, Housing Branch.

- 2007e. Transit-Oriented Design Guidelines. City of Ottawa, Planning and Growth Management Department.

2007f. Housing Needs in Ottawa. Report by the City of Ottawa's Community and Protective Services Committee. June 7, 2007.

-2008. Residential Intensification in Ottawa, 2001-2006. Publication No. 13-27. City of Ottawa, Planning and Growth Management Department.

- 2009a. Urban Design Guidelines for High Rise Housing. City of Ottawa, Planning and Growth Management Department.

2009b. Residential Land Strategy for Ottawa, 2006-2031. Publication No. 9-23. Ottawa: City of Ottawa.

- 2009c. City of Ottawa Official Plan Amendment: 5-Year Comprehensive Official Plan Review. City of Ottawa, Planning and Growth Management Department.

- 2009d. Barriers to Intensification: Conversations with Industry. City of Ottawa, Planning and Growth Management Department.

—2009e. Annual Development Report 2008. Publication No. 12-35. City of Ottawa, Planning and Growth Management Department. 
2011. Annual Development Report 2010. City of Ottawa, Planning and Growth Management Department.

Cormier, C. 2009. Housing as a Human Right: Understanding the Need to Align Toronto's Legal Planning Framework with City Council's Vision to End Homelessness \& the Affordable Housing Crisis, Journal of Hunger and Poverty, 1(1).

Commission on Planning and Development Reform for Ontario (CPDR), 1993. New Planning for Ontario: Final Report. Toronto: The Commission.

Cowen, D. 2004. Activist Planning and the Neoliberal City: The Case of Planning Action. http://www.plannersnetwork.org/publications/2004_summer/cowen.htm

Dance, J. 2012. Affordable housing endorsed by OECA. The Mainstreeter, May 2012.

Danielsen, K. and Fulton, W. 1999. Retracting Suburbia: Smart Growth and the Future of Housing, Housing Policy Debate, 10(3), 513-540.

Davidson, M. and Lees, L. 2005. New-build 'gentrification' and London's riverside renaissance, Environment and Planning A, 37, 1165-1190.

Dixon, J. and Dupuis, A. 2003. Urban Intensification in Auckland, New Zealand: A Challenge for New Urbanism, Housing Studies, 18(3), 353-368

Dreyfus, H. and P. Rabinow. 1982. Michel Foucault: Beyond Structuralism and Hermeneutics, Second Edition. Chicago: University of Chicago Press.

Dwyer, M. and C. Limb. 2001. Introduction: doing qualitative research in geography. In C. Limb and M. Dwyer (Eds.), Qualitative Methods for Geographers: Issues and Debates (pp. 1-22). London: Arnold Press.

Eastern Ontario Smart Growth Panel , 2003. Shape the Future: Eastern Ontario Smart Growth Panel Discussion Paper.

Escobar, A. 1996. Constructing Nature: Elements of a Poststructural Political Ecology. In R. Peet and M. Watts (Eds.), Liberation Ecologies: environment, development, social movements (pp. 46-68). London: Routledge.

External Advisory Committee on Cities and Communities. 2006. From Restless Communities to Resilient Places: Building a Stronger Future for All Canadians. Final Report. June 2006.

Feagan, R. and Ripmeester, M. 1999. Contesting Naturalized Lawns: A Geography of Private Green Space in the Niagara Region, Urban Geography, 20(7), 617-634.

Federation of Canadian Municipalities (FCM), 2001. Early Warning: Will Canadian Cities Compete? A Comparative Overview of Municipal Government in Canada, the United States 
and Europe. A Report Prepared for the National Round Table on the Environment and the Economy. Ottawa: FCM.

2004. Quality of Life in Canadian Communities: Incomes, Shelter and Necessities. Theme Report No.1. Ottawa: FCM .

2005. A New Deal for Cities and Communities. Submission to the Minister of Finance, January 27, 2005.

2006a. Building Prosperity From The Ground Up: Restoring Municipal Fiscal Balance. Ottawa: FCM.

2006b. Quality of Life in Canadian Communities: Growth, the Economy and the Urban Environment. Theme Report No.3. Ottawa: FCM.

Fischler, R., Meligrana, J. and Wolfe,J. 2004. Canadian Experiences of Local Government Boundary Reform: A Comparison of Quebec and Ontario. In J. Meligrana (Ed.), Redrawing Local Government Boundaries: An International Study of Politics, Procedures and Decisions, (pp. 75-105). Vancouver: UBC Press.

Florida, R. 2002. The rise of the creative class: and how it is transforming work, leisure, community and everyday life. New York: Basic Books.

Foucault, M. 1980. Power/Knowledge: Selected Interviews and other writings, 1972-1997. New:York: Pantheon Books.

Fullerton, C. 2005. A Changing of the Guard: Regional Planning in Ottawa, 1945-1974. Urban History Review, 34 (1), 100-112.

Gearin, E. 2004. Smart Growth or Smart Growth Machine? The Smart Growth Movement and its Implications. In J. Wolch, M. Pastor, and P. Dreier (Eds.), Up Against The Sprawl: Public Policy and the Making of Southern California. Minneapolis: University of Minnesota Press.

Gibbs, D. and Krueger, R. 2007. Containing the Contradictions of Rapid Development?: New Economy Spaces and Sustainable Urban Development. In R. Krueger and D. Gibbs (Eds.), The Sustainable Development Paradox: Urban Political Economic in the United States and Europe (pp. 95-122). New York: Guilford Press.

Gilbert, L. 2004. At the Core and on the Edge: Justice Discourses in Metropolitan Toronto. Space and Polity, 8(2), 245-260.

Government of Canada 2002. Canada's Urban Strategy: A Vision for the $21^{\text {st }}$ Century. A Report of the Prime Minister's Caucus Task Force on Urban Issues, April 2002.

_ 2005a. News Release: Government on track to deliver New Deal for Cities and Communities. Infrastructure Canada, February 1, 2005. 
— 2005b. Budget 2005. A New Deal for Canada's Communities, February 23, 2005.

Government of Ontario (2001). Ontario Smart Growth: Consultation Paper. Smart Growth Secretariat.

— 2002. Ontario Smart growth: A New Vision. Smart Growth Secretariat.

- 2003. Speech from the Throne: Strengthening The Foundation for Change. Address Of The Honourable James K. Bartleman, Lieutenant Governor Of Ontario On The Opening Of The Second Session Of The Thirty-Eighth Parliament Of The Province Of Ontario, November 20, 2003. Office of the Premier, Dalton McGuinty.

— 2004. Planning Reform: Ontario Municipal Board Reform. Ministry of Municipal Affairs and Housing.

- 2005a. 2005 Ontario Provincial Policy Statement.

2005b. Municipal Quality of Life for Economic Prosperity. Ministry of Municipal Affairs and Housing Provincial Planning and Environmental Services Branch.

2005c. ReNew Ontario 2005-2010: A five-year infrastructure investment plan to strengthen our economy and communities, Strategic Highlights.

2006. From Restless Communities to Resilient Places: Building a Stronger Future for All Canadians. Final Report of the External Advisory Committee on Cities and Communities. June 2006. Ottawa, Canada.

- 2006a. ReNew Ontario Progress Report 2006. Ministry of Public Infrastructure Renewal.

2006b. Places to Grow: Growth Plan for the Greater Golden Horseshoe. Ministry of Public Infrastructure Renewal.

-2008a. Provincial-Municipal Fiscal and Service Delivery Review. Ministry of Municipal Affairs and Housing.

- 2008b. Community Improvement Planning Handbook 2008. Ministry of Municipal Affairs and Housing.

Graham, S. 2006. Urban metabolism as target: contemporary war as forced demodernization. In the Nature of Cities: Urban Political Ecology and the Politics of Urban Metabolism (pp. 245-265). New York: Routledge.

Graham, K. and Phillips, S. 1998. "Who Does What" in Ontario: The process of provincialmunicipal disentanglement. Canadian Public Administration, 41(2), pp. 179-209. 
Gunder, M. 2006. Sustainability: Planning's Saving Grace or Road to Perdition? Journal of Planning Education and Research, 26, pp. 208-221.

Gurin, D. 2003. Understanding Sprawl: A Citizen's Guide. Vancouver: David Suzuki Foundation.

Hackworth, J. and Smith, N. 2001. The Changing State of Gentrification. Tijdschrift voor Economische en Sociale Geografie, 92(4), pp. 464-477.

Hackworth, J. and Moriah, A. 2006. Neoliberalism, Contingency and Urban Policy: The Case of Social Housing in Ontario, International Journal of Urban and Regional Research, 30(3), 510-527.

Haider, M. and Tomalty, R. 2009. Understanding the Smart Growth Gap. Ottawa: CMHC.

Hajer, M. 1995. The politics of environmental discourse: Ecological modernization and the policy process. Oxford: Oxford University Press.

Haraway, D. 1991. Simians, Cyborgs, and Women: The reinvention of nature, New York: Chapman \& Hall.

— 1997. Modest Witness@Second Millenium.FemaleMan@Meets_Onco Mouse ${ }^{T M}$ : Feminism and Technoscience. New York: Routledge.

Harvey, D. 1996. Justice, Nature and the Geography of Difference. Oxford: Blackwell Publishing Ltd.

Haughton, G. 1999. Environmental justice and the sustainable city. Journal of Planning Education and Research, 18, p.233-243.

Hemson Consulting Ltd. (2009). Comparative Municipal Fiscal Impact Analysis. Ottawa: City of Ottawa.

Heynen, N. 2003. The Scalar Production of Injustice within the Urban Forest. Antipode, p. 980998.

Heynen, N. and P. Robbins. 2005. The Neoliberalization of Nature: Governance, Privatization, Enclosure and Valuation. Capitalism, Nature, Socialism, 16(1), 5-8.

Heynen, N. and H. Perkins. 2005. Scalar Dialectics in Green: Urban Private Property and the Contradictions of the Neoliberalism of Water. Capitalism, Nature, Socialism, 16(1), 99-113.

Heynen, N., Kaika, M. and Swyngedouw, E. 2006. Urban political ecology: politicizing the production of urban natures. In N. Heynen, M. Kaika and E. Swyngedouw (Eds.), In the Nature of Cities: Urban Political Ecology and the Politics of Urban Metabolism (pp. 1-20). New York: Routledge. 
Heynen, N., McCarthy, J., Prudham, S., Robbins, P. (Eds.) 2007. Neoliberal Environments: False promises and unnatural consequences. New York: Routledge.

Hoggart, K., L. Lees, A. Davies. 2002. Researching Human Geography. London: Arnold Press.

Housing Network of Ontario (HNO). 2008. Building the Foundation for Ontario's Future: 5 Tests for Success Ontario's Long-Term Affordable Housing Strategy. Toronto, Canada.

2010. Ontario's proposed affordable housing plan fails to meet five basic tests set by Housing Network of Ontario. http://www.stableandaffordable.com/, retrieved December 15, 2010.

Hulchanski, D. 2002. Housing Policy for Tomorrow's Cities, Discussion Paper F/27, Family Network. Ottawa: Canadian Policy Research Network Inc.

Jacobs, J. 1992 [1961]. The Death and Life of Great American Cities. New York: Vintage Books.

Jonas, A. E. G., and While, A. 2007. Greening the Entrepreneurial City?: Looking for Spaces of Sustainability Politics in the Competitive City. In R. Krueger and D. Gibbs (Eds.), The Sustainable Development Paradox: Urban Political Economic in the United States and Europe (pp. 123-159). New York: Guilford Press.

Kaika, M. 2005. City of Flows: Modernity, Nature and the City. New York: Routledge.

Kaika, M. 2006. The political ecology of water scarcity: the 1989-1991 Athenian drought. In the Nature of Cities: Urban Political Ecology and the Politics of Urban Metabolism (pp. 157172). New York: Routledge.

Kalinosky, L. 2001. Smart Growth for Neighborhoods: Affordable Housing and Regional Vision. Report of the United States' National Neighbourhood Coalition, July 2001.

Katz, B. 2000. The Need to Connect Smart Growth and Affordable Housing, Speech before the Vermont Affordable Housing Conference, November 29, 2000.

Keil, R. 2002. "Common-Sense" Neoliberalism: Progressive Conservative Urbanism in Toronto, Canada. In N. Brenner and N. Theodore (Eds.), Spaces of neoliberalism: Urban restructuring in North America and Western Europe (pp. 230-253). Oxford: Blackwell.

Keil, R. 2005. Progress Report: Urban Political Ecology. Urban Geography, 26(7), 640-651.

Keil, R. 2007. Sustaining Modernity: Modernizing Nature: The Environmental Crisis and the Survival of Capitalism. In R. Krueger and D. Gibbs (Eds.), The Sustainable Development Paradox: Urban Political Economic in the United States and Europe (pp.41-65). New York: Guilford Press. 
Keil, R. and Desfor, G. 1996. Making environmental policy in Los Angeles. Cities, 13, 303-313.

Keil, R. and Graham, J. 1998. Reasserting Nature: Constructing urban environments after Fordism. In B. Braun and N. Castree (Eds.), Remaking Reality: nature at the millennium (pp. 100-125). London: Routledge.

Keil, R. and Boudreau, J. 2006. Metropolitics and metabolics: rolling out environmentalism in Toronto. In N. Heynen, M. Kaika and E. Swyngedouw (Eds.), In the Nature of Cities: Urban Political Ecology and the Politics of Urban Metabolism (pp. 41-62). New York: Routledge.

Kipfer, S. and Keil, R. 2002. Toronto Inc.? Planning the competitive city in the new Toronto. Antipode, 34 (2), 227-264.

Larsen, K. 2005. New Urbanism's Role in Inner-city Neighborhood Revitalization, Housing Studies, 20(5), 795-813.

Latour, B. 1993. We Have Never Been Modern. Cambridge: Harvard University Press.

Layard, A. 2001. Introduction: sustainable development - principles and practice. In A. Layard, S. Davoudi and S. Batty (Eds.) Planning for a sustainable future, (pp.1-6). London: Spoon Press.

Lees, L. 2008. Gentrification and Social Mixing: Towards an Inclusive Urban Renaissance? Urban Studies, 45(12), pp. 2449-2470.

Legislative Assembly of Ontario. 1994. Bill 163, Planning and Municipal Statute Law Amendment Act, Hansard Debate, June 161994.

- 1996. Legislative Assembly Committee Meeting, Bill 20, The Residents Rights' Act, February 12, 1996.

2001. Bill 56, Brownfields Statute Law Amendment Act, Hansard Debate, May 17, 2001.

Lehrer, U. and Wieditz, T. 2009. Condominium Development and Gentrification: The Relationship Between Policies, Building Activities and Socio-economic Development in Toronto. Canadian Journal of Urban Research, 18(1), pp. 140-161.

Leitner, H., Sheppard, E.S., Sziarto, K., and Marginganti, A.. 2007. Contesting Urban Futures: Decentering Neoliberalism. In H. Leitner, J. Peck, and E.S. Sheppard (Eds.), Contesting Neoliberalism: Urban Frontiers (pp. 1-25). New York: Guilford Press.

Loftus, A. 2006. The metabolic processes of capital accumulation in Durban's waterscape. In the Nature of Cities: Urban Political Ecology and the Politics of Urban Metabolism (pp. 173190). New York: Routledge. 
Marcuse, P. 1998. Sustainability is not enough. Environment and Urbanization, 10(2), pp.103111.

Martin, M. 2009. Fire and Ice: Unnatural Disasters and the Disposable Poor in Post-Apartheid Johannesburg, International Journal of Urban and Regional Research, 33(1), 165-192.

Marvin, S. and Medd, W. 2006. Metabolisms of obe-city: flows of fat through bodies, cities and sewers. In the Nature of Cities: Urban Political Ecology and the Politics of Urban Metabolism (pp. 143-156). New York: Routledge.

Mayer, M. 2007. Contesting the Neoliberalization of Urban Governance. In H. Leitner, J. Peck and E.S. Sheppard (Eds.), Contesting Neoliberalism: Urban Frontiers (pp. 90-115). New York: The Guilford Press.

McCann, E. 2007. Inequality and Politics in the Creative City-Region: Questions of Livability and State Strategy, International Journal of Urban and Regional Research. 31(3), 188-196.

McCarthy, J. 1998. Environmentalism, Wise Use, and the nature of accumulation in the rural West. In B. Braun and N. Castree (Eds.) Remaking Reality: nature at the millennium (pp. 126-149), London: Routledge.

McCarthy, J. 2002. First World Political Ecology: lessons from the Wise Use movement. Environment and Planning A, 34, 1281-1302.

McCarthy, J. and Prudham, S. 2004. Neoliberal nature and the nature of neoliberalism. Geoforum, 25, 275-283.

McGuinty, D. 2004. Speech to Big City Mayors Summit, September 17, 2004. Toronto, Ontario.

Meadowcroft, J. 1999. Planning for sustainable development: What can be learnt from the critics. In M. Kenny and J. Meadowcroft (Eds.) Planning Sustainability (pp.12-38), London: Routledge.

Miller, B. 2007. Modes of Governance, Modes of Resistance: Contesting Neoliberalism in Calgary. In H. Leitner, J. Peck and E.S. Sheppard (Eds.), Contesting Neoliberalism: Urban Frontiers (pp. 223-249). New York: The Guilford Press.

National Roundtable in the Environment and the Economy (NRTEE), 2003a. Environmental Quality in Canadian Cities: The Federal Role. Ottawa, Canada.

2003b. Cleaning up the Past, Building the Future: A National Brownfield Redevelopment Strategy for Canada. Ottawa, Canada.

Neuman, M. 2005. The Compact City Fallacy. Journal of Planning Education and Research, 25, 11-26. 
O'Brien, L. 2007a. Mayor's Speaker's Series, Inaugural Breakfast. Ottawa City Hall, Wednesday April 18, 2007.

2007b. Mayor's Speech, Ottawa Business Journal Breakfast. Ottawa City Hall, November 7, 2007.

Ontario Non-Profit Housing Association (ONPHA) 2006. ONPHA 'S 2006 Report on Waiting List Statistics For Ontario.

- 2010. Waiting lists survey 2010: ONPHA's 2010 Report on Waiting List Statistics for Ontario.

Ottawa Citizen. 2011. Fighting for diversity and affordability in Centretown. The Wrap, Volume 47.

- 2012. Where are we growing? As Ottawa's population continues to rise, can sprawl be stopped? April 20, 2012.

2012. Making intensification work for everyone: Critics say glitzy infill projects drive prices up and people to the suburbs. April 20, 2012.

Ottawa West EMC News. 2012. Affordable housing plan presented for Oblate lands, Project fits vision for neighbourhood, community association says. April 19, 2012.

Peck, J. 2005. Struggling with the Creative Class. International Journal of Urban and Regional Research, 29(4), 740-770.

Peck, J. and Tickell, A. 2002. Neoliberalizing Space. In N. Brenner and N. Theodore (Eds.), Spaces of Neoliberalism: Urban Restructuring in North American and Western Europe (pp. 33-57). Oxford: Blackwell Publishing.

Peet, R. and M. Watts 1996. Liberation Ecology: Development, sustainability, and environment in an age of market triumphalism. In R. Peet and M. Watts (Eds.), Liberation Ecologies: environment, development, social movements (pp. 1-45). London: Routledge.

Penfold, G. 1998. Planning Act Reforms and Initiatives in Ontario, Canada. In J. Schnurr and S. Holtz (Eds.), The Cornerstone of Development: Integrating Environmental, Social and Economic Policies, Ottawa: IDRC.

Pollution Probe 2001. S-M-A-R-T Movement: Save Money and the Air by Reducing Trips. Trip Reduction Manual.

Pond, D. 2009. Institutions, political economy and land-use planning policy: greenbelt politics in Ontario. Environmental Politics, 18(2), 238-256. 
Prudham, S. 2004. Poisoning the well: neoliberalism and the contamination of municipal water in Walkerton, Ontario. Geoforum, 35, 343-359.

Quastel, N. 2009. Political Ecologies of Gentrification. Urban Geography, 30(7), 694-725.

Raco, M. 2005. Sustainable Development, Rolled-out Neoliberalism and Sustainable Communities. Antipode, 324-347.

Rajchman, J. 1991. Philosophical Events. Essays of the 80s. New York: Columbia University Press.

Rast, J. 2006. Environmental Justice and the New Regionalism. Journal of Planning Education and Research, 25, 249-263.

Regional Planning Commissioners of Ontario (RPCO). 2001. Beyond Smart Growth: A Call to Action. A Policy Paper of the Regional Planning Commissioners of Ontario.

2010. Mechanisms to Ensure the Provision of Inclusionary Housing, RPCO Submission to PPS Five-Year Review.

Robbins, P. and Sharp, J. 2003a. The Lawn-Chemical Economy and Its Discontents. Antipode, 955-979.

Robbins, P. and Sharp, J. 2003b. Producing and Consuming Chemicals: The Moral Economy of the American Lawn. Economic Geography, 79(4), 425-451.

Robbins, P. and Sharp, J. 2006. Turfgrass subjects: the political ecology of urban monoculture. In the Nature of Cities: Urban Political Ecology and the Politics of Urban Metabolism (pp. 110-128). New York: Routledge.

Rose, D. 2004. Discourses and Experiences of Social Mix in Gentrifying Neighbourhoods: A Montreal Case Study. Canadian Journal of Urban Research, 13(2), pp. 278-316.

Said, E. 1994. Culture and Imperialism. New York: Vintage Books.

Sancton, A. 2000. Amalgamations, service realignment, and property taxes: did the Harris government have a plan for Ontario municipalities? Canadian Journal of Regional Science, $23(1), 135-56$.

Sancton, A. 2006. City Politics: Municipalities and Multi-Level Governance. In T. Bunting and P. Filion (Eds.), Canadian Cities in Transition: Local Through Global Perspectives, Third Edition (pp. 306-319). Oxford: Oxford University Press.

Schroeder, R., K. St. Martin, K. Albert. 2006. Political Ecology in North America: Discovering the Third World Within. Geoforum, 37, 163-168. 
Sewell, J. 1993. The Shape of the City: Toronto Struggles with Modern Planning. Toronto: University of Toronto Press.

2009. The Shape of the Suburbs: Understanding Toronto's Sprawl. Toronto: University of Toronto Press.

Shapcott, M. 2001. The Alternative Budget 2001: Made-in-Ontario housing crisis. Technical Paper No.12. Canadian Centre for Policy Alternatives. Toronto, Canada.

2006. Framework for the Blueprint to End Homelessness in Toronto. Toronto: Wellesley Institute.

2007. Ten things you should know about housing and homelessness in Canada. Toronto: Wellesley Institute.

- 2008. Housing, homelessness and Ontario's Poverty Reduction Strategy. Toronto: Wellesley Institute.

Sierra Club of Canada. 2003. Sprawl Hurts Us All!: A guide to the costs of sprawl development and how to create livable. Toronto: Sierra Club of Canada.

Smith, L. 1983. The Crisis of Rental Housing: A Canadian Perspective. Annals of the American Academy of Political and Social Science, 465, p. 58-75.

Smith, L. and Ruiters, G. 2006. The public/private conundrum of urban water: a view from South Africa. In the Nature of Cities: Urban Political Ecology and the Politics of Urban Metabolism (pp. 191-207). New York: Routledge.

Smith, N. 2002. New Globalism, New Urbanism: Gentrification as a Global Urban Strategy. Antipode, 427-450.

Smith, N. 2008 [1984]. Uneven Development: Nature, Capital and the Production of Space. Athens: University of Georgia Press.

Smith, N. 2008b. On 'The Eviction of Critical Perspectives'. International Journal of Urban and Regional Research, 32(1), 195-197.

Smith, S. 2001. Doing qualitative research: from interpretation to action. In C. Limb and M. Dwyer (Eds.), Qualitative Methods for Geographers: Issues and Debates (pp. 23-40). London: Arnold Press.

Social Planning Council of Ottawa. 2004. Consultations on Ottawa's 2004 Budget: Summary Report. Ottawa: SPC.

Swyngedouw, E. 2004. Social Power and the Urbanization of Water. Oxford: Oxford University Press. 
Swyngedouw, E. 2006. Metabolic urbanization: the making of cyborg cities.. In N. Heynen, M. Kaika and E. Swyngedouw (Eds.), In the Nature of Cities: Urban Political Ecology and the Politics of Urban Metabolism (pp. 21-40). New York: Routledge.

Swyngedouw, E. and Heynen, N. 2003. Urban Political Ecology, Justice and the Politics of Scale. Antipode, p. 898-918.

Swyngedouw, E., Moulaert, F., and Rodriguez, A. 2002. Neoliberal Urbanization in Europe: Large-Scale Urban Development Projects and the New Urban Policy In N. Brenner and N. Theodore (Eds.), Spaces of Neoliberalism: Urban Restructuring in North America and Western Europe Europe (pp. 197-229). Oxford: Blackwell Publishing.

United Nation's World Commission on Environment and Development (WCED). 1987. Our Common Future. Oxford: Oxford University Press.

Veron, R. 2006. Remaking urban environments: the political ecology of air pollution in Delhi. Environment and Planning A, 38, 2093-2109.

Wainwright, J. 2005. The geographies of political ecology: after Edward Said. Environment and Planning A, 37, 1033-1043.

Ward, K. and Jonas, A.E.G. 2004. Competitive city-regionalism as a politics of space: a critical reinterpretation of the new regionalism. Environment and Planning A, 36, 2119-2139.

Weber, R. 2002. Extracting Value from the City: Neoliberalism and Urban Redevelopment. In N. Brenner and N. Theodore (Eds.), Spaces of Neoliberalism: Urban Restructuring in North America and Western Europe Europe (pp. 172-193). Oxford: Blackwell Publishing.

Wekerle, G. 2001. Resisting Sprawl: Environmental Challenges and Sustainable Regional Planning. Leading Edge 2001: Focus on the Biosphere Reserve, October 17-19, 2001. Toronto: Niagara Escarpment Commission.

Wellesley Institute. 2009. Inclusionary Housing An Important Tool in a Long Term Affordable Housing Strategy. Toronto: Wellesley Institute.

Whatmore, S. 2002. Hybrid Geographies: Natures, Cultures, Spaces. London: Sage Publications.

While, A., Jonas, A., and Gibbs, D. 2004. The Environment and the Entrepreneurial City: Search for the Urban 'Sustainability Fix' in Manchester and Leeds. International Journal of Urban and Regional Research, 28(3), 549-569.

Winfield, P. 2003. Smart Growth in Ontario: The Promise vs. Provincial Performance. Calgary: Pembina Institute for Appropriate Development. 
2006. Building Sustainable Urban Communities in Ontario: A Provincial Progress Report. Calgary: Pembina Institute for Appropriate Development.

Wolch, J. Pastor, M., Dreier, P. 2004. Introduction. Making Southern California: Public Policy, Markets, and the Dynamics of Growth. In J. Wolch, M. Pastor, and P. Dreier (Eds.) Up Against the Sprawl (pp.1-41). Minnesota: University of Minnesota Press.

Young, D. and R. Keil. 2005. Urinetown or Morainetown? Debates on the Reregulation of the Urban Water Regime in Toronto. Capitalism, Nature, Socialism, 16(2), 61-84. 
APPENDIX: List of Interviews

\begin{tabular}{|c|c|c|}
\hline & Interview & Date \\
\hline 1 & Member, local environmental organization & 27 November 2007 \\
\hline 2 & Member, local environmental organization & 30 November 2007 \\
\hline 3 & Community Planner, City of Ottawa & 3 December 2007 \\
\hline 4 & Community Planner, City of Ottawa & 12 December 2007 \\
\hline 5 & Member, City of Ottawa Advisory Committee & 17 December 2007 \\
\hline 6 & Housing planner, City of Ottawa & 19 December 2007 \\
\hline 7 & Member, neighbourhood community association & 9 January 2008 \\
\hline 8 & Member, neighbourhood community association & 10 January 2008 \\
\hline 9 & Not-for-profit housing developer & 17 January 2008 \\
\hline 10 & Real estate developer & 26 January 2008 \\
\hline 11 & Real estate developer & 14 February 2008 \\
\hline 12 & Community planner (independent) & 18 February 2008 \\
\hline 13 & Real estate developer & 3 March 2008 \\
\hline 14 & City of Ottawa Advisory Committee, member & 11 March 2008 \\
\hline 15 & Planner, City of Ottawa & 18 March 2008 \\
\hline 16 & Member, local environmental organization & 20 March 2008 \\
\hline 17 & Member, local environmental organization & 1 April 2008 \\
\hline 18 & Planner, City of Ottawa & 22 May 2008 \\
\hline 19 & Planner, City of Ottawa & 6 June 2008 \\
\hline 20 & Chair, local environmental organization & 10 June 2008 \\
\hline 21 & Real estate developer & 28 January 2009 \\
\hline 22 & City Councillor, City of Ottawa & 31 January 2009 \\
\hline$\overline{23}$ & Community Planner, City of Ottawa & 3 February 2009 \\
\hline 24 & Senior policy analyst, $\mathrm{CMHC}$ & 7 February 2009 \\
\hline 25 & City Councillor, City of Ottawa & 11 February 2009 \\
\hline 26 & City Councillor, City of Ottawa & 13 February 2009 \\
\hline 27 & City Councillor, City of Ottawa & 4 March 2009 \\
\hline 28 & Member, neighbourhood community association & 14 March 2009 \\
\hline 29 & Real estate developer & 17 March 2009 \\
\hline 30 & City Councillor, City of Ottawa & 18 March 2009 \\
\hline 31 & Housing planner, City of Ottawa & 18 March 2009 \\
\hline 32 & Member, neighbourhood community association & 19 March 2009 \\
\hline 33 & Members (2), neighbourhood community association & 24 March 2009 \\
\hline 34 & Member, neighbourhood community association & 17 April 2009 \\
\hline 35 & Planner, City of Ottawa & 25 April 2009 \\
\hline 36 & City Councillor, City of Ottawa & 30 April 2009 \\
\hline 37 & Member, neighbourhood community association & 4 May 2009 \\
\hline 38 & City Councillor, City of Ottawa & 5 May 2009 \\
\hline 39 & Members (2), neighbourhood community association & 15 May 2009 \\
\hline 40 & Member, neighbourhood community association & 20 May 2009 \\
\hline 41 & City Councillor, City of Ottawa & 22 May 2009 \\
\hline 42 & Member, neighbourhood community association & 23 May 2009 \\
\hline
\end{tabular}




\begin{tabular}{|l|l|l|}
\hline 43 & City Councillor, City of Ottawa & 25 May 2009 \\
\hline 44 & Social/community activist & 4 June 2009 \\
\hline 45 & Real estate developer & 25 June 2009 \\
\hline 46 & Recreation planner, City of Ottawa & 9 July 2009 \\
\hline 47 & Former Mayor, City of Toronto & 28 July 2009 \\
\hline 48 & Member, community-based environmental organization & 8 May 2010 \\
\hline 49 & Not-for-profit housing developer & 19 June 2010 \\
\hline
\end{tabular}

